UNIVERSIDADE DE SÃO PAULO

FACULDADE DE ECONOMIA, ADMINISTRAÇÃO E CONTABILIDADE DEPARTAMENTO DE ADMINISTRAÇÃO PROGRAMA DE PÓS-GRADUAÇÃO EM ADMINISTRAÇÃo

CLAUDIA CHERON KÖNIG

AVALIAÇÃO DO PAPEL DAS AGÊNCIAS DE PROMOÇÃO DE EXPORTAÇÃO E INVESTIMENTO NOS FLUXOS DE NEGÓCIOS ENTRE PAÍSES 
Prof. Dr. Marco Antônio Zago

Reitor da Universidade de São Paulo

Prof. Dr. Adalberto Américo Fischmann

Diretor da Faculdade de Economia, Administração e Contabilidade

Prof. Dr. Roberto Sbragia

Chefe do Departamento de Administração

Prof. Dr. Moacir de Miranda Oliveira Júnior

Coordenador do Programa de Pós-Graduação em Administração 


\section{AVALIAÇÃO DO PAPEL DAS AGÊNCIAS DE PROMOÇÃO DE EXPORTAÇÃO E INVESTIMENTO NOS FLUXOS DE NEGÓCIOS ENTRE PAÍSES}

Tese apresentada ao Programa de PósGraduação em Administração do Departamento de Administração da Faculdade de Economia, Administração e Contabilidade da Universidade de São Paulo, como requisito parcial para a obtenção do título de Doutor em Ciências.

Orientador: Prof. Associado Paulo R. Feldmann

Versão Corrigida

(versão original disponível na Biblioteca da Faculdade de Economia, Administração e Contabilidade) 
FICHA CATALOGRÁFICA

Elaborada pela Seção de Processamento Técnico do SBD/FEA/USP

König, Claudia Cheron.

Avaliação do papel das agências de promoção de exportação e investimento nos fluxos de negócios entre países / Claudia Cheron König. -- São Paulo, 2016. 209 p.

Tese (Doutorado) - Universidade de São Paulo, 2016.

Orientador: Paulo Roberto Feldmann.

1. Internacionalização de empresas. 2. Exportação. 3. Investimen- tos estrangeiros. 4. Agências de fomento I. Universidade de São Pau-

lo. Faculdade de Economia, Administração e Contabilidade. II. Título.

CDD - 658.049 
Aos meus pais, que plantaram a semente da curiosidade;

Ao Jan, que me deu força e coragem para enfrentar esse desafio; Ao Samuel, que sofreu com cada hora que dediquei à pesquisa, abrindo mão de estar ao seu lado.

À minha irmã caçula, Maria de Fatima, que me apoiou e me ajudou de todas as maneiras possíveis na pesquisa e, principalmente, ao me substituir inúmeras vezes no papel de mãe, para que eu pudesse me dedicar a esse sonho. 



\section{AGRADECIMENTOS}

À Coordenação, aos professores e aos funcionários do Programa de Pós-Graduação em Administração da Faculdade de Economia, Administração e Contabilidade da Universidade de São Paulo, pelo apoio;

Ao meu orientador, Prof. Dr. Paulo Roberto Feldmann, a quem sou imensamente grata pela orientação, compreensão e amizade;

Aos colegas de curso, Claudio Soares de Moura e Oliveira, Daniela de Moraes Aviani e, em especial, Éder Januário de Carvalho, pelas incontáveis horas de discussões e apresentações da minha tese;

À Prof. Dra. Sylvia Saes (FEA-USP), pelas diversas contribuições intelectuais e afetivas.

Aos Professores Dr. Moacir Miranda de Oliveira Junior (FEA-USP) e Dr. Frederico Turolla (ESPM), que, em banca de qualificação, levantaram pontos extremamente pertinentes acerca do projeto, os quais redirecionaram a pesquisa;

Ao Prof. Dr. Gilmar Masieiro (FEA-USP), que teve grande participação na escolha do tema desta tese, e ao Prof. Dr. Ivan Filipe Almeida Lopes Fernandes (UFABC), que foi essencial para o desenvolvimento da pesquisa quantitativa;

E, especialmente à minha família: meus pais, Claudemir Cheron e Marlene Gonçalves de Lima Cheron, pelo carinho, dedicação e amor constante; minha irmã, Ligia Cheron Gallardo, e meus cunhados, Danilo Gallardo e Ricardo Pires, pelas horas que dedicaram suas atenções aos cuidados do Samuel e à leitura do meu trabalho; minha irmã, Maria de Fatima de Lima Cheron, para quem minha gratidão será eterna, por ter ficado ao meu lado nos momentos mais difíceis e cansativos, contribuindo de todas as maneiras possíveis e imagináveis. Por fim, ao Jan König, meu marido, companheiro, conselheiro e amigo, sem o qual a vida não teria graça;

À Maria Beatriz Salomoni, por todo o carinho que dedicou ao Samuel nos momentos em que não pude estar presente, o meu muito obrigado. Você me deu a tranquilidade necessária para que eu pudesse concluir minha pesquisa. 

"Deve-se escrever da mesma maneira com que as lavadeiras lá de Alagoas fazem em seu oficio. Elas começam com uma primeira lavada, molham a roupa suja na beira da lagoa ou do riacho, torcem o pano, molham-no novamente, voltam a torcer. Colocam o anil, ensaboam $e$ torcem uma, duas vezes. Depois enxáguam, dão mais uma molhada, agora jogando água com a mão. Batem o pano na laje ou na pedra limpa, $e$ dão mais uma torcida e mais outra, torcem até não pingar do pano uma só gota. Somente depois de feito tudo isso é que elas dependuram a roupa lavada na corda ou no varal, para secar. Pois quem se mete a escrever devia fazer a mesma coisa. A palavra não foi feita para enfeitar, brilhar como ouro falso; a palavra foi feita para dizer."

(Graciliano Ramos, Linhas Tortas, 1962). 



\section{RESUMO}

Assimetrias de informação entre países de acolhimento e de origem das empresas constituem um obstáculo significativo aos fluxos comerciais e de investimento através das fronteiras internacionais, levando a uma importante questão política: como os governos podem ajudar as empresas na redução dessa barreira, auxiliando-as no processo de internacionalização? Diante da enorme concorrência no mercado internacional, nota-se que cada vez um número maior de governos encontra nas Agências de Promoção de Exportação e de Investimento (APEIs) um instrumento para o apoio a competitividade das empresas nacionais no mercado global. $\mathrm{O}$ papel das APEIs tem gradualmente influenciado os fluxos de mercadorias e capitais em um contexto cada vez mais dinâmico e competitivo entre empresas e países. Mas qual é o impacto da presença da agência (APEI) nos fluxos de comércio e investimento entre os países? Aspectos institucionais influenciam na atuação da agência? A aprendizagem da APEI em um determinado mercado resulta em maior impacto nos fluxos comerciais entre o país de origem da APEI e o país hospedeiro? Com o intuito de responder a essas questões, construiu-se um banco de dados com informações econômicas e institucionais para o Brasil e mais 220 países entre os anos de 1995 a 2015. Os fluxos comerciais e de investimento entre o Brasil e os demais países são as variáveis dependentes do estudo. Além disso, foram coletados dados de 20 agências de promoção de exportação e investimento atuantes no mercado brasileiro. Para a realização da análise optou-se pela adoção de um estimador de painéis dinâmicos com efeito fixo. A utilização de um modelo dinâmico - com uma variável dependente defasada - foi adotada para reduzir potenciais vieses de variáveis omitidas que houvesse em um modelo estático, uma vez que alguns determinantes dos fluxos podem estar relacionados com a criação das agências. Os resultados mostram que o impacto da presença das agências sobre os fluxos não pode ser ignorado, revelando-se estatisticamente significante para fluxos comerciais e de saída de IDE brasileiro. O efeito da aprendizagem da APEI no país hospedeiro também é significante para os fluxos comerciais do país de origem da agência para o país hospedeiro. Os testes indicam um efeito da presença da agência sobre o impacto da distância cultural e geográfica sobre os fluxos. Há diferença de impacto da agência dependendo de a quem ela esteja subordinada dentro do governo. Apontaram-se as limitações desta tese bem como se destacou sugestões de direcionamento de novas pesquisas com o intuito de progredir no conhecimento e dos fatores que afetam o impacto da presença das APEIs sobre os fluxos entre os países.

Palavra-Chave: Internacionalização de empresas; Exportação; Investimento estrangeiro; Agência de fomento. 


\begin{abstract}
Information asymmetry between business' host and home countries establishes a significant hindrance to trade and investment flows across international borders, leading to an important policy question: How can government help businesses to reduce this barrier by providing supporting in the internationalization process? Due to massive competition in the global market, more and more governments have discovered an instrument to boost the competitiveness of domestic enterprises internationally: the Export and Investment Promotion Agencies (EIPA). In the context of increasing dynamics and competitiveness among companies and countries, EIPA have gradually influenced the flow of goods and capital. However, what is the impact of EIPA's presence on trade and investment flows between countries? Do institutional aspects have influence in the agency's performing? Do EIPA's experiences in a specific market result in a greater impact on trade flows between an EIPA's home country and its host countries? In order to answer these questions a database of economic and institutional information from Brazil and other 220 countries between the years 1995 and 2015 was elaborated. Trade and investment flows between Brazil and the corresponding countries are the dependent variables of the study. In addition, data were collected from 20 foreign EIPA, which act in the Brazilian market. An estimator of dynamic panel data with fixed effects was used to conduct the analysis. A dynamic panel data model with a lagged dependent variable was used to reduce potential biases of omitted variables in a static model - since some flow determinants could have been related to the creation of the proper EIPA. The results demonstrate that the impact on the flows caused by the presence of EIPA should not be ignored, once the tests reveal such presence as statistically significant for trade flows and Brazilian FDI output. The learning effect of an EIPA in the host country is also significant for the trade flow from the EIPA's home country to the host country. The results prove the effect of such presence, changing the impact of cultural and geographic distance. The effect seems to depend also on the organizational subordination of the EIPA within the government. Limitations of this thesis have been pointed out and future research directions have been suggested in order to enhance the knowledge and understanding of the factors that actually affect the impact of EIPA's presence on flows between countries.
\end{abstract}

Keywords: Internationalization of companies; Exports; Foreign direct investment; Export and investment promotion agency. 


\section{SUMÁRIO}

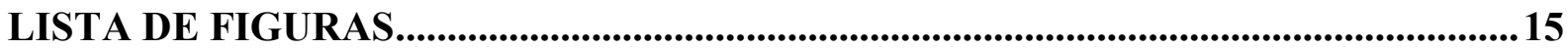

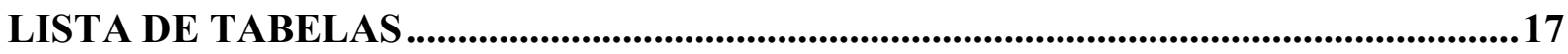

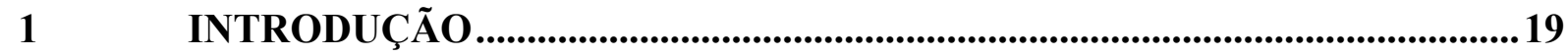

1.1 Objetivos de pesquisa .......................................................................................................24

1.2 Justificativa, relevância e contribuições esperadas do estudo............................25

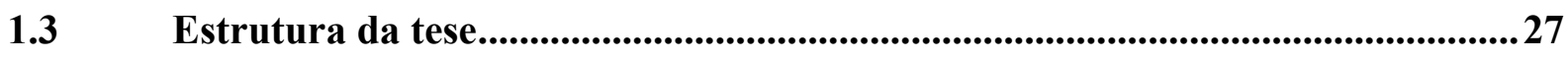

2 REFERENCIAL TEÓRICO......................................................................29

2.1 Competitividade internacional de um país e de suas empresas..........................29

2.1.1 Competitividade das Nações ..........................................................29

2.1.1.1 Teorias Clássicas de Comércio Internacional .......................................................... 29

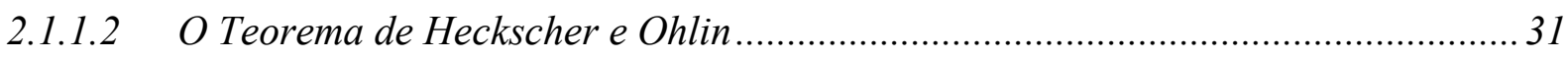

2.1.1.3 As Teorias de Comércio de Produtos Industrializados ............................................. 32

2.1.1.4 Teoria de Vantagem Competitiva das Nações .......................................................... 34

2.1.1.4.1 Determinantes da Vantagem Competitiva .......................................... 35

2.2 Internacionalização de Empresas....................................................................40

2.2.1 Oportunidades e Ameaças da Internacionalização das Empresas............42

2.2.2 Benefícios, Riscos e Custos da Internacionalização. .............................43

2.2.3 Teorias de Internacionalização ..................................................... 48

2.2.3.1 A Teoria Eclética da Internacionalização da Firma ................................................. 51

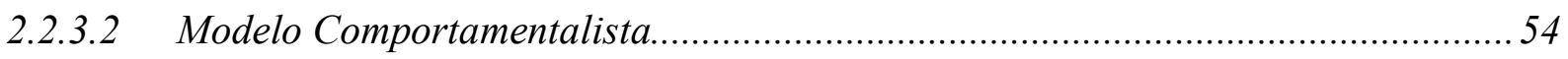

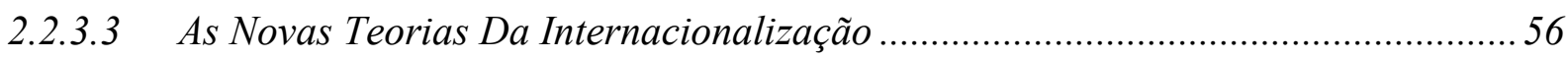

2.2.4 Escolha da Forma de Internacionalização........................................60

2.3 Fundamentação Econômica............................................................................66

2.3.1 Teoria dos Custos de Transação......................................................66

2.3.2 Visão Baseada em Recursos (VBR) ou Resource Based View (RBV) .......69

2.3.3 Visão Baseada em Conhecimento (VBC) ou Knowledge Based View (KBV) 72

2.3.4 A Governança do Conhecimento............................................... 78

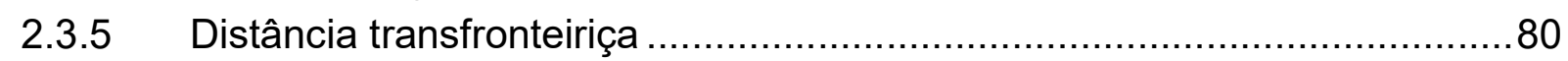

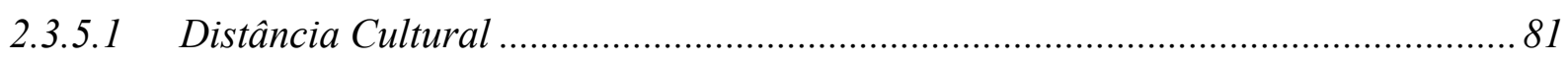

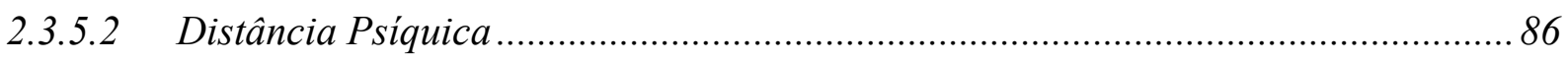

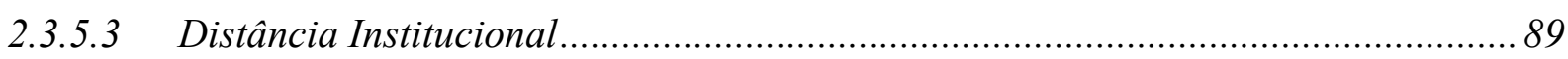

2.4 Políticas Públicas de Suporte a Exportação e Internacionalização ...................93

2.5 O Papel das Agências de Promoção à Exportação e ao Investimento (APEI) 102

APEX-Brasil............................................................................................... 110

3 FORMULAÇÃO DE HIPÓTESES............................................................115

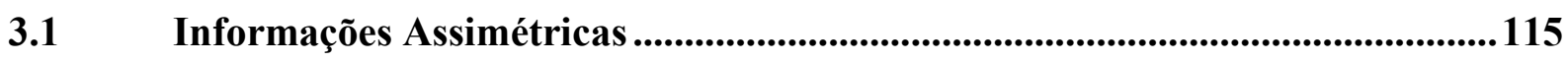


3.2 Aprendizagem.................................................................................................. 117

3.3 Distância cultural ............................................................................................. 118

3.4 Distância geográfica .................................................................................... 119

3.5 Controle Societário e Autonomia Organizacional ............................................... 120

4 METODOLOGIA DE PESQUISA ..................................................................... 122

4.1 Método do Estudo ................................................................................................... 123

4.2 Modelo Conceitual ......................................................................................... 124

4.3 Seleção e Descrição de Variáveis ........................................................................ 126

4.4 Modelo Econométrico ..................................................................................... 131

4.5 Extensões Metodológicas ...................................................................................... 134

4.6 Seleção da Amostra e Coleta de Dados ……………………................................. 136

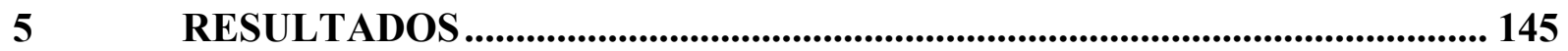

5.1 Impacto da presença da APEI sobre os fluxos do país de origem para o país hospedeiro da agência ................................................................................................................ 147

5.2 Impacto da presença da APEI sobre os fluxos do país hospedeiro para o país de origem da agência................................................................................................................. 150

5.3 Impacto da Aprendizagem da APEI sobre os fluxos do país de origem da agência para o país hospedeiro ...................................................................................... 152

5.4 Impacto da aprendizagem da APEI sobre os fluxos do país hospedeiro para o país de origem da agência......................................................................................................... 154

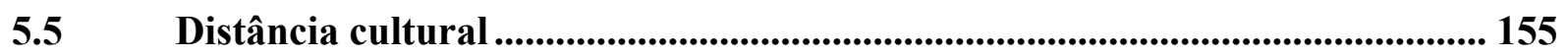

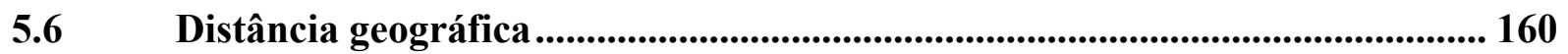

5.7 Controle societário e autonomia organizacional................................................ 165

5.8 Discussões dos resultados ................................................................................ 172

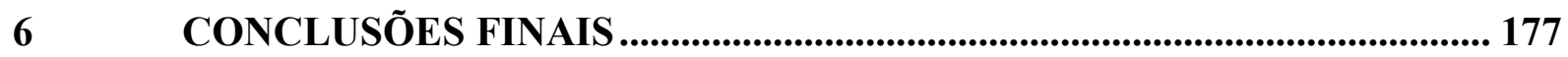

6.1 Limitações da pesquisa e possibilidades de estudos futuros ............................... 181

REFERÊNCIAS BIBLIOGRÁFICAS ........................................................................... 183 


\section{LISTA DE FIGURAS}

Figura 1 - Entrada de IDE por grupo de economia, 1990-2015 ….......................................26

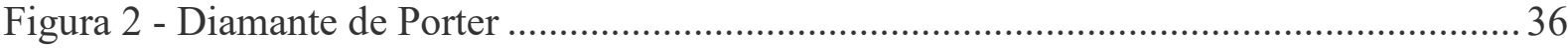

Figura 3 - Árvore de decisão para a entrada no mercado externo segundo a teoria eclética de

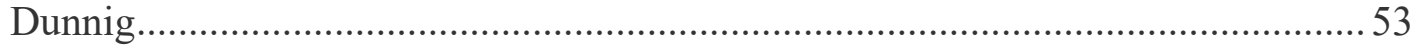

Figura 4 - Processo de Internacionalização segundo Johanson/Vahlne ....................................56

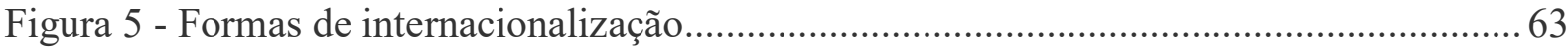

Figura 6 - Instrumentos de apoio ao investimento direto no exterior (países desenvolvidos),

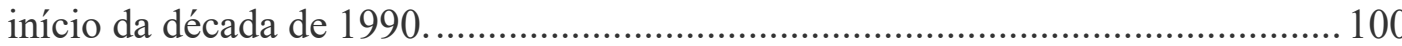

Figura 7 - Padrão de classificação para as políticas públicas de fomento ao processo de internacionalização.

Figura 8 - Principais funções exercidas pelas APEIs .............................................................. 108

Figura 9 - Portfólio de serviços e escritórios da Apex-Brasil no exterior ............................... 113

Figura 10 - Desdobramentos das hipóteses H1a e H1b ........................................................... 117

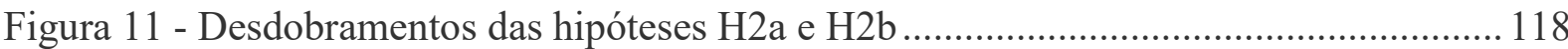

Figura 12 - Desdobramentos da hipótese H3 .................................................................... 119

Figura 13 - Desdobramentos da hipótese H4 _................................................................... 120

Figura 14 - Desdobramentos das hipóteses H5a, H5b e H5c ............................................. 121

Figura 15 - Modelo conceitual do estudo ............................................................................. 125

Figura 16 - Variáveis para a análise dos fluxos comerciais .............................................. 130

Figura 17- Variáveis para a análise dos fluxos de investimento ......................................... 131

Figura 18 - Modelos de equações dinâmicas para a realização do estudo ............................ 133

Figura 19 - Modelos modificados com as variáveis de aprendizagem da APEI .................... 134

Figura 20 - Modelos com a variável de interação entre APEI e distância cultural ................. 135

Figura 21 - Modelos com a variável de interação entre APEI e distância ............................ 135

Figura 22 - Modelos modificado para a análise da estrutura da APEI no impacto sobre os fluxos....

Figura 23 - Países com fluxos de investimento com o Brasil................................................. 137

Figura 24 - Países com fluxos comerciais com o Brasil......................................................... 138

Figura 25 - Variáveis utilizadas no estudo ...................................................................... 139

Figura 26 - APEIs com presença no Brasil selecionadas para participar do estudo............... 145

Figura 27 - Países com presença da APEX Brasil................................................................ 146

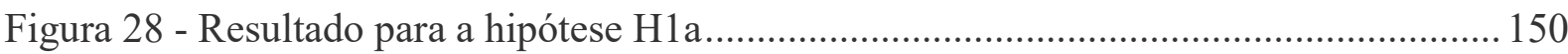

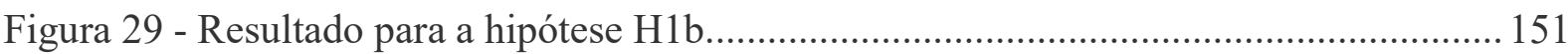

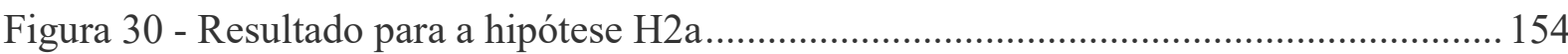


Figura 31 - Resultado para a hipótese 2B

Figura 32 - Interação da APEX no efeito da distância cultural sobre as exportações brasileiras

Figura 33 - Interação da APEI no efeito da distância cultural sobre as importações brasileiras

Figura 34 - Interação da APEX no efeito da distância cultural sobre a saída de IDE brasileiro

Figura 35 - Interação da APEI no efeito da distância cultural sobre a entrada de IDE do Brasil....

Figura 36 - Resultado para a hipótese H3 com a distância cultural de Berry at.al.

Figura 37 - Interação da APEX no efeito da distância geográfica sobre a exportação

Figura 38 - Interação da APEI no efeito da distância geográfica sobre a importação

Figura 39 - Interação da APEX no efeito da distância geográfica sobre a saída de IDE........164

Figura 40 - Interação da APEI no efeito da distância geográfica sobre a entrada de IDE......164

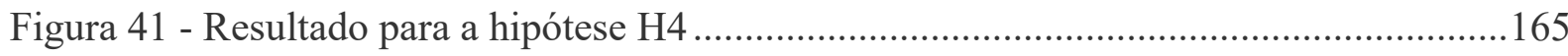

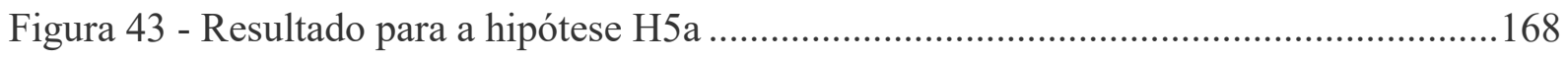

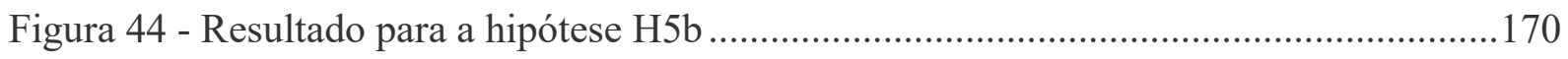

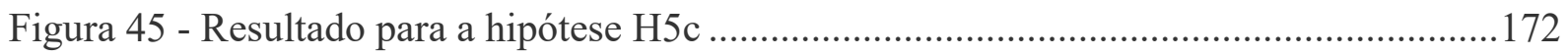




\section{LISTA DE TABELAS}

Tabela 1 - Estatística descritiva das variáveis 146

Tabela 2 - Modelos de painéis dinâmicos para a presença da agência do país de origem no país hospedeiro sobre os fluxos do país de origem para o país hospedeiro 148

Tabela 3 - Modelos de painéis dinâmicos para a presença da agência do país de origem no país hospedeiro sobre os fluxos do país hospedeiro para o país de origem

Tabela 4 - Modelos de painéis dinâmicos para a aprendizagem da presença da agência do país de origem no país hospedeiro sobre os fluxos do país de origem para o país hospedeiro

Tabela 5 - Modelos de painéis dinâmicos para a aprendizagem da presença da agência do país de origem no país hospedeiro sobre os fluxos do país hospedeiro para o país de origem

Tabela 6 - Modelos de painéis dinâmicos para o efeito da interação da agência com a distância cultural medida de acordo com Berry, at.al. (2010).............................................. 156

Tabela 7 - Modelos de painéis dinâmicos para o efeito da interação da agência com a distância geográfica (logarítmica) entre os países parceiros.

Tabela 8 - Modelos de painéis dinâmicos para o impacto do controle societário no efeito das agências sobre os fluxos

Tabela 9 - Modelos de painéis dinâmicos para o efeito das diferentes autonomias nos fluxos entre os países

Tabela 10 - Modelos de painéis dinâmicos para o efeito das diferenças de subordinações das agências sobre os fluxos entre os países 



\section{INTRODUÇÃO}

O século XXI vivenciou mudanças radicais no ambiente de negócios que conecta empresas e consumidores, devido a forças sociais importantes e algumas vezes interligadas que criaram novos comportamentos, oportunidades e desafios. Entre o século XX e o XXI, ocorreu uma evolução das relações econômicas, antes marcadamente caracterizadas pela produção e consumo em massa, para um momento em que os níveis de produção foram aprimorados e as ofertas e comunicações, mais direcionadas. Os avanços tecnológicos facilitaram os negócios internacionais e, para os consumidores, permitiram o acesso à compra de produtos e serviços de empresas estrangeiras.

Os governos vêm percebendo que o dinamismo das economias nacionais em um contexto de integração e competição está mais focado nas empresas e não nos próprios países (Porter, 1989; Krugman, 1996; Dunning, 2003). O crescimento nacional passa fundamentalmente pela capacidade de um estado em catalisar e instigar a competitividade das empresas em seu território. Diante da enorme concorrência entre mercados, adotar medidas que visem o incremento da competitividade passa a ter uma relevância estratégica por parte não apenas das corporações, mas também dos países. Neste contexto, a estruturação de ambiente e condições favoráveis à internacionalização é fundamental (Vietor, 2007; Teixeira, 2006), uma vez que a competitividade internacional de suas empresas passa a ser um fatorchave na disputa do jogo de poder e prosperidade nacional (Unctad, 2005a; 2006; 2008; Barral, 2011; IPEA, 2012).

Desta maneira, não apenas os estados continuam sendo uma força muito importante na formação da economia mundial e do desenvolvimento econômico dos países (Dickens, 2010; Castells, 1999), como também passam a adotar políticas governamentais específicas de promoção da inserção internacional de suas empresas com objetivo de incrementar as suas capacidades competitivas (Porter, 1989; IPEA, 2012; Vietor, 2007).

A questão ganha força no ambiente estratégico internacional, com a verificação de que múltiplos governos passaram a aceitar o seu vínculo com a internacionalização das empresas, optando pelo seu auxílio e incentivo (Além \& Cavalcanti, 2005; Stopford, Strange \& Henley, 1991; Dicken, 2010; Strange, 1994; 1996; 2000; Grosse, 2005; Vietor, 2007; Teixeira, 2006; Unctad, 2005a; 2006; 2008; Vernon, 1998; Barral, 2011; IPEA, 2012). Neste contexto, o conceito de políticas comerciais assume um papel de políticas de internacionalização, envolvendo desde aspectos de exportações até o investimento direto estrangeiro (IDE). 
O elevado crescimento econômico de Hong Kong, Singapura, Coréia e Taiwan, na década de 1990, atraiu muita atenção como modelos de desenvolvimento econômico para outros países emergentes (Banco Mundial, 1993). Um fator-chave por trás do rápido crescimento e desenvolvimento da região foi uma estratégia de crescimento voltada para o mercado externo, o que aumentou as suas exportações para o mundo (Hayakawa, Lee \& Park, 2011). Outro exemplo recente de crescimento baseado na exportação é a impressionante ascensão da China como uma superpotência econômica. A transformação espetacular da China foi alimentada por um crescimento explosivo de suas exportações, que saltaram de 52 bilhões de dólares americanos em 1990 para 1,435 bilhões de dólares em 2008 (Indicadores de Desenvolvimento Mundial).

No Brasil, novas frentes de interação entre a internacionalização de suas empresas e a participação do governo também estão presentes. Diversos estudos realizados no país (Cyrino \& Tanure, 2009; Fleury \& Fleury, 2009; Cyrino, Oliveira Jr \& Barcellos, 2010; Borini et al., 2010; Valor, 2011; Coelho, 2014) constatam que algumas empresas brasileiras buscam a inserção internacional como estratégia para conquistar vantagens de produtividade, competitividade e lucratividade. Isso tem promovido impactos positivos aos seus participantes, considerando que vários deles obtiveram taxas de crescimento acima da média em relação aos concorrentes domésticos e enfrentaram com relativo sucesso os grandes players estabelecidos nos mercados internacionais em que atuam (Cyrino \& Penido, 2007). Em razão disso, o Brasil acompanha a agenda internacional acerca da existência, formato e prática de políticas governamentais de apoio à internacionalização das empresas nacionais (Fleury \& Fleury, 2009).

Recentemente, há um crescente reconhecimento de que o IDE gera benefícios para os países de origem do capital. Navaretti, Castellani \& Disdier (2010) constataram que na Itália o IDE teve um efeito positivo em longo prazo sobre a geração de empregos dos investidores em casa e na França o efeito foi positivo tanto sobre a produção nacional quanto sobre a geração de empregos (Hayakawa, Lee, \& Park, 2014). Além disso, Hayakawa, Matsuura, Motohashi \& Obashi (2013) constataram que o IDE japonês em países desenvolvidos e países em desenvolvimento aumentaram a demanda por trabalhadores de maior qualificação e não envolvidos diretamente com a produção no país de origem do capital (Hayakawa et al., 2014). Isso significa que o IDE contribui para o crescimento e desenvolvimento dos países de origem do capital, levando a repercussões positivas de produtividade para as empresas locais, especialmente nas indústrias fornecedoras (Harding \& Javorcik, 2010). Fleury e Fleury (2011) também apontam que há evidências de que o desenvolvimento de competências tecnológicas 
em empresas brasileiras tem sido fortemente melhorado através de mecanismos de aprendizagem, e que muitas empresas conseguiram modernizar, atualizar, ampliar sua produtividade e competitividade nos mercados mundiais.

Tal constatação é relevante, uma vez que o envolvimento dos governos na esfera dos negócios internacionais foi mundial e historicamente, se deu quase que exclusivamente nas vantagens provenientes do comércio internacional, focando-se, portanto, em políticas comerciais de promoção das exportações reguladas pelas dinâmicas e padrões derivados das vantagens comparativas ricardianas (Coelho, 2014). Até então, os governos se restringiam a políticas comerciais e industriais - horizontais e setoriais -, pelas quais suas intervenções tinham por objetivo incentivar padrões comerciais tidos como relevantes ao bem-estar de suas populações, contanto com fatores estruturais de produção de suas economias.

No entanto, o IDE é uma atividade inerentemente arriscada para as empresas porque envolve incorrer em grandes custos irrecuperáveis, como o custo de aquisição de informação para superar a falta de conhecimento e familiaridade com o mercado local (Janeba, 2002; Hayakawa et al., 2014). Em outras palavras, a informação assimétrica (falta de conhecimento das preferências dos consumidores, fornecedores e outras características-chave de mercados estrangeiros) é uma grave falha de mercado que desencorajam o investimento em países estrangeiros, ou mesmo as exportações (Hayakawa et al., 2011; Hayakawa et al., 2014).

Diante destes fatos, a relação dos governos com suas empresas atuantes no mercado internacional tornou-se uma agenda política, econômica e organizacional (Guedes, 2006). Desta maneira, surgiram pesquisas, interessadas, sobretudo, na reflexão sobre as formas e maneiras pelas quais esses atores se relacionam e lidam com as complexidades contemporâneas na realidade da economia global (Castells, 1999).

Os governos devem desenvolver politicas de curto prazo que apoiem as organizações nas áreas onde se constatam as maiores dificuldades para a internacionalização. Estudos realizados (Brasil, Arruda, Leonel \& Goulart, 1996; Iglesias \& Veiga, 2005; Sauvant, 2005; BNDES, 1995) identificaram que a falta de recursos gerenciais e habilidades para a internacionalização, bem como a falta de recursos financeiros suficientes e disponibilidade de informação útil se destacam como as maiores dificuldades. É a partir de tais necessidades que as Agências de Promoção de Exportação e Investimentos (APEIs) merecem destaque, por atuarem, exatamente, para suprir esse déficit.

As APEIs têm como papel fundamental enquanto se estabelecem nos mercados, desenvolver um produto extremamente valioso para governos e organizações - o 
conhecimento. Este conhecimento é tratado como um recurso valioso e que terá um papel crucial nas relações comerciais que a agência promoverá entre países.

$\mathrm{O}$ aspecto do conhecimento como um recurso, procede da teoria da Visão da Firma Baseada em Recursos (VBR) que foi conceituada como essência da gestão estratégica (Foss, 1997). A VBR apresenta uma base teórica sobre a importância dos recursos, como o conhecimento, no incremento da competitividade sustentável da empresa (Lee, Lee, \& Kang, 2005). Assim, com esta perspectiva pautada nos recursos, as organizações ou países buscam vantagem competitiva, baseando-se nos conhecimentos desenvolvidos, tácitos e explícitos dentro dos distintos cenários (Hendriks \& Vriens, 1999).

Ao contrário dos estoques financeiros, de recursos naturais ou mesmo de mão de obra não qualificada, o valor econômico do conhecimento não é tão facilmente compreendido, classificado e medido, uma vez que é um recurso invisível, intangível e difícil de imitar. O conhecimento diferenciado entre mercados determina vantagens competitivas distintas entres os países e as organizações. A gestão do conhecimento influencia a tomada de decisão e determina a conjuntura das estratégias que organizações e países assumem diante dos cenários futuros, buscando melhorar as suas respectivas posições no mercado internacional.

Neste contexto, o surgimento das APEI resulta dos esforços por parte do governo em mitigar os elevados riscos em mercados internacionais e promover um aumento da competitividade das empresas nacionais, via exportações e investimentos no exterior, além de buscar atrair o investimento estrangeiro (Hayakawa et al., 2014). Desde o seu lançamento em 1995, The World Association of Investment Promotion Agencies (WAIPA) vem registrando um número cada vez maior de membros que representam cidades, regiões, países e zonas de livre comércio. Em 2002 existiam 112 membros, em 2013 chegou-se a 170, envolvendo 130 países (WAIPA).

As atividades das APEIs governamentais e semigovernamentais podem ser justificadas por determinadas falhas de mercado (Hayakawa et al., 2011). Portanto, se APEIs governamentais são capazes de fornecer informações sobre mercados estrangeiros para as empresas nacionais, elas podem agir como um catalisador para o aumento das exportações (Hayakawa et al., 2011).

Embora as APEIs, tradicionalmente, tenham sido uma ferramenta utilizada pelos países, muitas vezes é difícil de avaliar com precisão a eficácia delas. Mais precisamente, é difícil estabelecer se a presença de um escritório da APEI em um país de destino incentiva empresas do país de origem a exportarem ou investirem naquele país de destino. A principal fonte de dificuldade é o problema de endogeneidade. Ou seja, o governo do país de origem da 
APEI pode decidir pela criação de um escritório da APEI no país de destino precisamente porque muitas empresas do país de origem estão investindo no país de destino. Por outro lado, a decisão pode ser baseada simplesmente na boa relação entre os países, ou relativamente atraente clima de investimento do país de destino (Hayakawa et al., 2014).

Uma série de estudos tem avaliado o papel das agências governamentais na promoção das atividades de negócios internacionais de empresas de seus países. A maioria dos estudos existentes com esse enfoque é sobre a promoção das exportações e atração de IDE. Estudos de promoção das exportações, que incluem Alvarez e Crespi (2000), Gil-Pareja, Vivero e Serrano (2008) e Martincus e Carballo (2008) encontraram uma correlação significativa das promoções das exportações e o volume de exportações (Hayakawa et al., 2014). Em um estudo recente com base em dados de pesquisa que abrangem 103 países desenvolvidos e em desenvolvimento, Lederman, Olarreaga e Payton (2010) confirmam as conclusões anteriores de agências de promoção de exportações, exercendo um efeito positivo significativo sobre as exportações (Hayakawa et al., 2014). Eles destacam a importância dos serviços das APEIs para superar as barreiras comerciais estrangeiras e resolver problemas de informação assimétrica associados à exportação (Hayakawa et al., 2014).

Estudos de promoção de atração de IDE examinaram se os esforços dos governos dos países de acolhimento para atrair investidores estrangeiros para o país são eficazes ou não (Hayakawa et al., 2014). Em geral, esses estudos, que incluem Charlton e Davis (2007) e Harding e Javorcik (2010), mostraram um efeito positivo da promoção de IDE na entrada de IDE no país. Em contraste com o grande e crescente número de estudos sobre exportação e promoção de IDE, quase não há estudos que analisam as importações e promoção de saída de IDE (Hayakawa et al., 2014). Isto é perfeitamente compreensível, porque a prioridade tradicional dos governos tem sido a de promover as exportações e entradas de IDE, e apenas recentemente eles começaram a promover importações e saídas de IDE (Hayakawa et al., 2014).

Neste cenário, a questão de pesquisa focal a ser respondida neste estudo, com o intuito de contribuir para o entendimento do tema proposto, é a seguinte:

Qual é o impacto da presença da agência (APEI) nos fluxos de comércio (exportação e importação) e de investimento direto estrangeiro (entrada e saída de IDE) entre os países?

Pretende-se investigar se as APEIs atuam como redutores de custos de transações no mercado internacional à medida que reduzem as assimetrias de informações. Ao oferecem informações sobre os mercados, as APEIs podem ser vislumbradas como um fator de indução e potencialização de vantagens que se somem à justificativa da internacionalização. E, neste 
toar, se a APEI pode fazer alguma diferença na internacionalização de empresas do país, e, em caso positivo, em qual intensidade e por quais motivos.

\subsection{Objetivos de pesquisa}

Neste contexto, a presente tese direciona os esforços a investigar empiricamente o impacto da presença da APEI tanto sobre os fluxos de saída (exportação e investimento direto estrangeiro), quanto sobre os fluxos de entrada (importação e investimento direto estrangeiro no Brasil). O objetivo é analisar o quanto a presença das APEIs impacta nos fluxos de transação comercial e de investimento entre os países. Além disso, esta tese propõe-se a verificar se o efeito da presença da APEI difere em ambientes institucionais distintos, com culturas diferentes. Em outras palavras, se a presença da APEI em países com maior distancia cultural apresenta impacto maior sobre o fluxo do que quando presentes em países com menor distância cultural em relação ao país de origem.

Para lançar luz sobre o efeito da promoção de exportação e IDE, selecionou-se o Brasil como foco de análise, verificando-se tanto o impacto da presença de APEIs de outros países quanto o impacto da presença da Agência Brasileira de Promoção de Exportação e Investimento (APEX-BRASIL), sobre os fluxos comerciais e de investimentos (entrada e saída) brasileiros.

Para alcançar esse objetivo geral, alguns objetivos específicos se fizeram pertinentes:

i. Desenvolver um framework de interpretação do fenômeno da competitividade internacional de um país e da importância de suas empresas, neste contexto;

ii. Desenvolver um framework de interpretação do fenômeno da internacionalização de empresas, o qual permita compreender seus principais determinantes e dificuldades;

iii. Desenvolver um referencial de análise do ambiente institucional e apurar como este impacta a entrada das empresas em novos mercados, bem como nos fluxos comerciais e de investimento entre os países;

iv. Compreender o papel estratégico das APEIs no contexto da Visão Baseada em Recursos;

v. Verificar a função da APEI sob a ótica da Economia de Custos de Transação; 
vi. Analisar as funções principais da APEI;

vii. Definir um método quantitativo que possa verificar o impacto das APEIs nos fluxos comerciais entre os países.

A estratégia de investigação adotada para explorar o problema de pesquisa proposto, bem como para atingir os objetivos pretendidos, é de natureza predominante quantitativa, realizada por meio da construção de um banco de dados em forma de painel, que foi criado para compreender o impacto do ambiente institucional nos fluxos de negócios entre os países e o efeito da presença das APEIs. As técnicas de análise utilizadas foram painel de dados dinâmico e de efeito fixo. Espera-se, com isso, ante o problema e os objetivos propostos, que a suas consecuções, por meio de investigação guiada pela metodologia escolhida, apontem resultados que possam sugerir se as agências apoiam a internacionalização, ou ainda, como esse apoio é mais ou menos eficiente.

\subsection{Justificativa, relevância e contribuições esperadas do estudo.}

De acordo com Buckley (2002), a evolução histórica dos Negócios Internacionais (NI) foi marcada por três períodos que compreendem: (i) do pós-Segunda Guerra até os anos 1970, quando se voltou à explicação dos fluxos dos investimentos direto estrangeiros (IDE); (ii) dos anos 1970 aos 1990, período no qual o empenho foi dedicado ao entendimento do surgimento, funcionamento e estratégia das organizações multinacionais; e, por fim, (iii) dos anos 1990 aos 2000, quando ocorreram análises de novos temas da internacionalização das empresas e dos novos desdobramentos da globalização.

Segundo Coelho (2014), uma dimensão-chave que inaugura uma nova agenda de pesquisa e reflexão parace emergir: os governos. Embora o governo seja reconhecido na agenda de pesquisa de NI, o seu papel no processo de internacionalização tem se mostrado pouco explorado (Lemos, 2013). Como observou Lemos (2013), poucos estudos se dedicam a explorar o fenômeno da internacionalização como uma questão emergente nas relações entre governos e empresas pela ótica das dinâmicas dos negócios das empresas, o que ocorre, contudo, na literatura de Ciência Política (Boddewyn, 1992; Stopford et al., 1991; Dickens, 2010; Strange, 1994; 1996; 2000; Grosse, 2005; Vietor, 2007; Guedes, 2006; Musacchio \& Lazzarini, 2013; Camilo, Marcon \& Bandeira-de-Mello, 2012). 
As empresas enfrentam as suas questões de formação de vantagens específicas em ambientes nos quais outros atores são fundamentais, com destaque aos governos (Buckley, 1998). Esses podem facilitar o processo de internacionalização tanto desenvolvendo ambientes favoráveis à competição como disponibilizando instrumentos diretos determinantes das escolhas das empresas (Sousa \& Lemos, 2009). Os governos, ao fornecerem informações, reduzirem custos de transação e diminuírem as restrições de recursos, podem influenciar a decisão das empresas sobre as maneiras de alocar os seus ativos, podendo, com isso, serem importantes fatores de vantagens das empresas (Wang, Hong, Kafouros \& Wright, 2012).

A presente tese se justifica com o objetivo de se adentrar a essas questões, com os seus esforços de investigação especificamente empenhados em explorar a atuação dos governos, por meio das APEIs, sobre a internacionalização de empresas, analisadas através dos fluxos comerciais (exportação e importação) e de IDE (entrada e saída).

Wells e Wint foram os primeiros estudiosos que notaram que os governos ansiosos para atrair investimentos diretos estrangeiros (IDE) passaram a empreender um tipo específico de marketing chamado de promoção de investimentos, que cresceram rapidamente na sua forma institucionalizada há relativamente pouco tempo (Moran, Graham, \& Blomström, 2005; Wells \& Wint, 2000). Atualmente, a promoção de investimentos está relacionada ao crescimento sem precedentes de IDE nas últimas duas décadas (Figura 1), o que se tornou, provavelmente, a fonte mais proeminente de capital privado para os países em desenvolvimento e economias em transição.

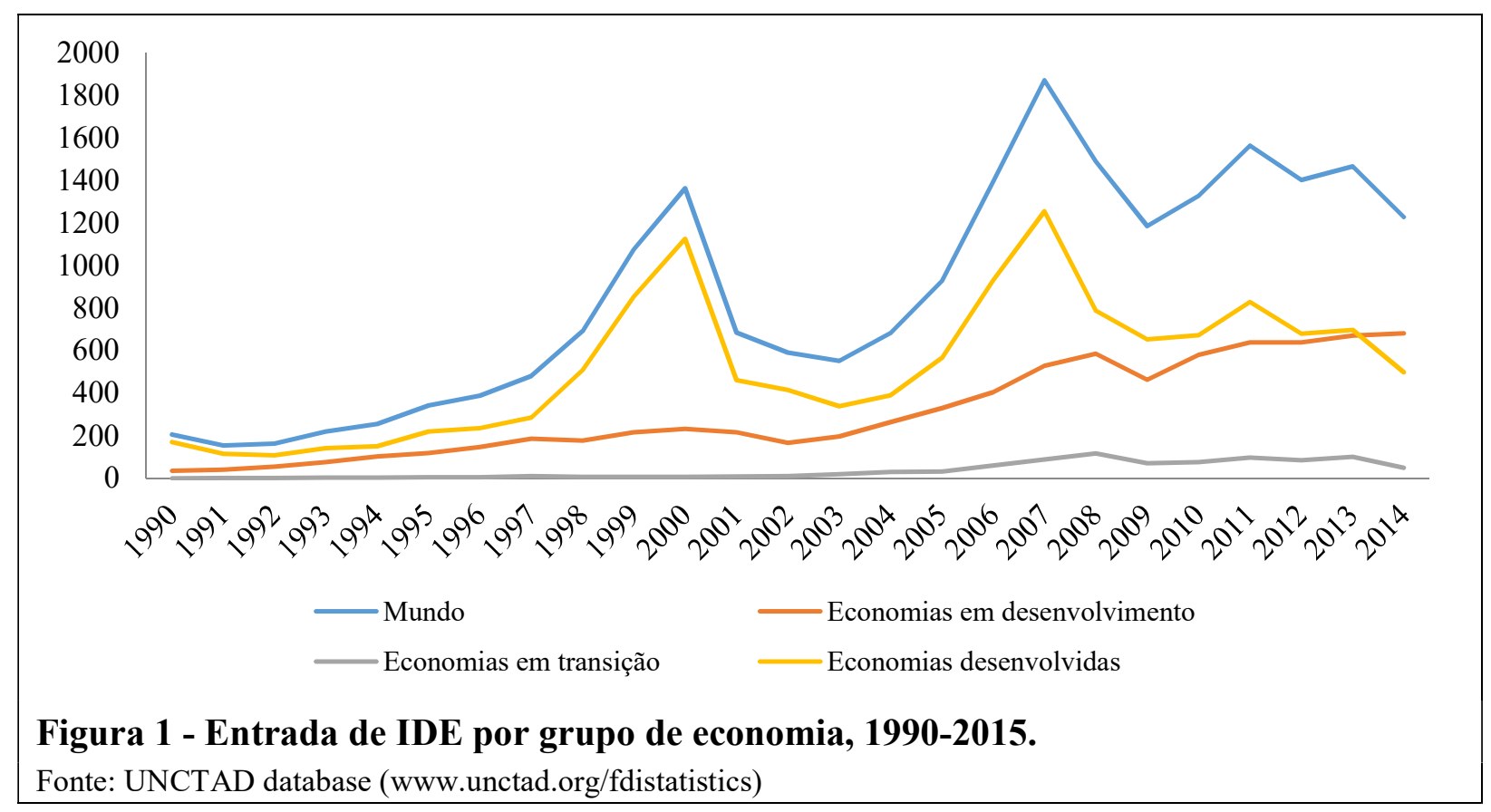


Assim, observam-se esforços proativos dos governos para atrair IDE e auxiliar suas empresas em mercados internacionais, sendo a criação das APEIs resultado direto desses esforços. Esta tese investiga o impacto específico das APEIs. Busca-se, nesta pesquisa, não apenas verificar o efeito da presença das APEIs nas variações dos fluxos comerciais e de investimentos, mas também como essas APEIs interagem em diferentes ambientes institucionais, onde elas são mais eficientes, em que situações essas APEIs mostram maior relevância. No contexto em que há concorrência feroz para a atração de IDE, quais os fatores mais relevantes para a instituição da APEI? Para quais mercados os governos devem direcionar o investimento da implantação de uma unidade da agência? De uma maneira geral, pode-se dizer que essa é a principal contribuição desta tese.

Em um nível mais amplo, espera-se contribuir com a literatura empírica sobre o papel das APEIs em atividades comerciais transfronteiriças, ao abordar tanto os fluxos de saída quanto os de entrada, além de considerar a presença das APEIs dos países de origem e de destino do fluxo. Além disso, a pesquisa discute a relação das agências com os fluxos em um país em desenvolvimento, o Brasil, o que torna nosso estudo relevante, dado o recente surgimento de países em desenvolvimento, como exportadores globais e origem de IDE. Com relação às suas contribuições acadêmicas, espera-se que os resultados e achados desta tese apresentem a necessidade de se inserir a presença das agências como uma variável significativa para às análises dos fluxos comerciais e de investimentos, sendo considerada como um possível fator de promoção de vantagens de propriedade das firmas, tanto em sua constituição quanto potencialização. Esta tese é um complemento para a literatura relacionada com os processos de internacionalização. Ela será focada nos papéis das agências no processo de internacionalização das empresas, um tema relativamente pouco pesquisado na literatura de Negócios Internacionais (NI).

\subsection{Estrutura da tese}

Para atingir os objetivos gerais e específicos propostos, constituindo-se reflexões, interpretações e resultados capazes de explorar adequadamente o problema de pesquisa suscitado, a presente tese está organizada em cinco seções, além desta introdução: Referencial Teórico; Hipóteses de Pesquisa; Metodologia de Pesquisa; Apresentação e Análise dos Resultados; e Conclusões. Na seção do Referencial Teórico são realizadas seis etapas fundamentais: (i) a definição do conceito de competitividade internacional de um país e de 
suas empresas; (ii) a compreensão do processo de internacionalização das empresas; (iii) fundamentação econômica para a compreensão do processo, através da construção de um framework para a sua intepretação através da economia institucional; (iv) as políticas públicas de suporte à exportação e a internacionalização; bem como a (v) definição do papel das Agências de Promoção de Exportação e Investimento; e, (vi) a contextualização da pesquisa.

$\mathrm{Na}$ seção posterior, Formulação de Hipóteses, a partir do referencial teórico construído, são levantadas hipóteses de pesquisa com objetivo de inferir sobre o impacto das APEIs na internacionalização das empresas, ou, melhor explicado, nos fluxos comerciais e de investimento. Na Metodologia de Pesquisa é justificada a escolha da estratégia de investigação, particularmente a construção de um painel dinâmico, amostragem e de seus métodos de análise. As partes finais se iniciam pela seção de Resultados, oportunidade em que serão apresentados os resultados descritivos e inferenciais da pesquisa, bem como análise sobre o teste de hipótese, o cenário e modelos observados. E, finalmente, na seção Conclusões Finais, será feito um apanhado geral da pesquisa, com vistas a posicionar os principais achados e indicar as suas limitações e novos caminhos de pesquisa. 


\section{REFERENCIAL TEÓRICO}

\subsection{Competitividade internacional de um país e de suas empresas}

\subsubsection{Competitividade das Nações}

\subsubsection{Teorias Clássicas de Comércio Internacional}

Discussões que influenciaram a teoria econômica moderna sobre comércio internacional surgiram a partir da segunda metade do século XVIII. O conhecimento acerca do comércio exterior, até aquela época, restringia-se à escola mercantilista, que explicava o comércio internacional pela oportunidade de obtenção de excedente na balança comercial, sendo o superávit comercial o objetivo a ser atingido (Coutinho, Peixoto \& Amaral, 2005).

A teoria das vantagens absolutas foi elaborada por Smith (1985), em trabalho originalmente publicado em 1776. Para esse autor, maior produtividade na produção de um bem, ocasiona a vantagem absoluta de um país. Segundo Smith, as vantagens obtidas com as trocas comerciais não são geradas pelos excedentes de comércio exterior.

A produção de um país deve estar concentrada nos bens nos quais se alcançam vantagens absolutas, exportando o excedente do consumo interno e utilizando a receita equivalente para importar os bens produzidos em outro país. Segundo Smith (1985), após a realização das trocas, a capacidade de consumo dos países envolvidos no comércio internacional será maior, o que eleva o bem-estar da sociedade.

Ricardo (1982) levou essa teoria um pouco adiante ao mostrar, com uma explicação sistemática no seu livro The Principles of Political Economy and Taxation (1817), que há a possibilidade de ganhos por meio das trocas comerciais também para aqueles países que não possuem vantagens absolutas em relação a outros, uma vez que o que determina a possibilidade de se beneficiar do comércio é o princípio da vantagem comparativa, e não o princípio da vantagem absoluta.

A vantagem comparativa reflete o custo de oportunidade, que pode ser entendido como as quantidades de um produto que um país precisa deixar de produzir para focar sua produção em outro bem (Neumann, 1995). Segundo Ricardo, as vantagens comparativas se originam nas diferenças de produtividade do fator trabalho para distintos bens. Os países deveriam se especializar, aumentando a produção doméstica, nos bens dos quais possuem 
vantagem comparativa, exportando o excedente do consumo doméstico e adquirindo, no mercado internacional, os outros bens a um preço menor que o da produção interna, o que faria o comércio favorável para todos.

Assim, cada país obviamente dedica seu capital e seu trabalho à atividade que lhe seja mais benéfica, buscando vantagens individuais, que, consequentemente, associam-se ao bem dos demais países. Dessa maneira, é possível facilitar o uso mais eficaz das potencialidades naturais, dividindo o trabalho de modo mais eficiente e mais econômico, ao mesmo tempo em que o aumento geral do volume de produtos expande o benefício de modo geral, atrelando países civilizados por laços comuns de interesse e de intercâmbio (Ricardo, 1982).

O modelo de Ricardo coloca que de forma lógica um país exportará produtos nos quais tem maior produtividade relativa do trabalho e importará aqueles nos quais sua produtividade relativa é menor (Coutinho et al., 2005).

\footnotetext{
"A Inglaterra exportava tecidos em troca de vinho porque, dessa forma, sua indústria se tornava mais produtiva; teria mais tecidos e vinhos do que se os produzisse para si mesma; Portugal importava tecido e exportava vinho porque a indústria portuguesa poderia ser mais beneficamente utilizada para ambos os países na produção de vinho". (Ricardo, 1982: 107).
}

Mill (1983) confirmou a percepção da vantagem comparativa de Ricardo ao afirmar que um país com custos reais altos exportaria artigos de algum tipo, mesmo que para países que os poderiam produzir com menos trabalho. Isso porque, mesmo supondo que esses países tivessem vantagens absolutas sobre ele em todos os produtos, teriam vantagem maior em algumas mercadorias do que em outras e, consequentemente, importariam artigos em que sua vantagem fosse mínima, com o intuito de empregar seus bens de capitais nos produtos com máxima vantagem.

Os modelos clássicos apresentam lacunas que são alvo de contestação. Segundo Young (1963), as críticas se encontram nas premissas de mercado perfeito, imobilidade de trabalho e capital, custos constantes e mobilidade no mercado nacional suposições do modelo, tais como competição perfeita dentro de cada país, imobilidade completa de trabalho e capital entre os países.

Coutinho et al. (2005) afirmam, que apesar das restrições, diversos estudos empíricos confirmam a suposição de Ricardo, de que os países tenderiam a exportar bens cuja produtividade é relativamente alta e importar aqueles cuja produtividade é relativamente baixa. 


\subsubsection{O Teorema de Heckscher e Ohlin}

O teorema de Heckscher e Ohlin diverge do modelo de Ricardo, uma vez que diferencia o comércio internacional do comércio inter-regional e identifica os fatores que determinam a existência de vantagens comparativas.

Enquanto o modelo de Ricardo (1982) supõe que a existência de vantagens comparativas surge por causa da diferença na produtividade do trabalho entre os países, o modelo de Heckscher-Ohlin indica que as vantagens comparativas originam-se nos fatores de produção e nos diferentes níveis de estoques relativos, o que influencia os custos de produção dos bens. Apesar de tecnologias equivalentes, as nações apresentam diferentes disponibilidades dos fatores de produção (terra, recursos naturais, mão-de-obra e capital), sendo que o país irá produzir o bem que necessita do fator de produção que estiver em abundância (Coutinho et al., 2005).

Logo, no modelo de Heckscher-Ohlin, a abundância relativa de fatores de produção determinará na produção de qual bem um país se especializará, realizando a exportação desses bens e, em contrapartida, importando aqueles cujos fatores produtivos sejam relativamente escassos em seu território (Coutinho et al., 2005).

Segundo Krugman e Obstefeld (2001), fatos recentes do comércio internacional que contribuíram para a incapacidade de a teoria explicar a realidade atual estão relacionados ao crescente comércio de produtos com proporções de fatores semelhantes na produção, e o avanço de multinacionais, que criaram um novo padrão de fluxo de comércio, ao realizar a importação e a exportação entre diferentes subsidiárias de uma mesma firma.

A maior limitação desse modelo se encontra na falta de realismo dos seus pressupostos para explicar os sistemas comerciais. Outro ponto importante é que os limites da capacidade explicativa desse modelo surgem de seus pressupostos: a inexistência de economias de escala e a homogeneidade das tecnologias empregadas e dos produtos (Neumann, 1995). Contudo, os custos dos fatores e suas disponibilidades relativas são relevantes para as indústrias que empregam muitos recursos naturais, tecnologia comum e mão-de-obra desqualificada (Coutinho et al., 2005).

Apesar das limitações, a teoria da vantagem comparativa teve impacto na determinação das políticas governamentais, uma vez que admitiu a possibilidade de os governos alterarem a vantagem comparativa de fatores produtivos por meio de intervenção, justificando assim a utilização de políticas para a diminuição dos custos relativos das 
empresas de um país em comparação aos seus concorrentes internacionais (Williamson, 1989).

\subsubsection{As Teorias de Comércio de Produtos Industrializados}

As principais linhas teóricas do comércio de produtos industrializados voltam o enfoque para os aspectos de economias de escala, o papel da demanda, os ciclos do produto e a concorrência monopolística. Krugman e Obstefeld (2001) afirmam que essas teorias buscam analisar as seguintes características do comércio mundial: um comércio em rápida expansão e de alta intensidade entre países com as mesmas características de fatores produtivos, volume elevado de troca de produtos muito similares e um baixo grau de conflito social como resultado da vasta liberalização do comércio no período do pós-guerra.

Segundo Coutinho et al. (2005), a vertente teórica que destaca o papel das economias de escala argumenta que, ao aumentar a quantidade produzida, os custos da empresa ou do mercado se reduzem, levando à formação, não de um mercado de concorrência perfeita, mas sim de um mercado no qual as firmas tenham certo grau de poder. Desta maneira, os países produziriam uma variedade limitada de bens, favorecendo-se dos retornos crescentes de escala, sem renunciar à variedade no consumo, uma vez que essa é possibilitada pelo comércio internacional. Como resultado, países com composição de fatores e gostos idênticos podem ganhar com o comércio entre si.

Uma distinção entre o comércio de produtos primários e o comércio de produtos industrializados foi estabelecida pelo economista sueco Staffan Burenstam Linder em sua publicação An Essay on Trade and Transformation de 1961. Segundo o autor, o modelo de Heckscher-Ohlin explica o comércio de produtos primários, enquanto os modelos de comércio de produtos industrializados têm maior poder de explicação para a estrutura da demanda, caracterizada pelas qualidades dos produtos diferenciados procurados num país (Appleyard \& Field, 1998).

Ainda segundo o autor, a estrutura da demanda é determinada, principalmente, pelo nível de renda per capita, sendo o consumo de produtos sofisticado maior em países de renda per capita mais elevada do que em países menos desenvolvidos.

Os países limitariam suas produções aos bens correspondentes à faixa de qualidade dos produtos do seu mercado interno. As razões para isso estariam, principalmente, na dificuldade das empresas locais em identificar a existência de uma demanda que não está 
presente no mercado nacional, além da falta de familiaridade com essa demanda, o que torna improvável o desenvolvimento de produtos com as características desejadas para o êxito comercial (Linder, 1961). Linder concluiu, com isso, que o comércio de produtos industrializados é, portanto, maior entre países com níveis de renda semelhantes. Tal conclusão diverge do modelo de Heckscher-Ohlin, o qual supõe maior potencial de comércio entre países com diferentes níveis de renda per capita e, consequentemente, diferentes razões de capital-trabalho (Coutinho et al., 2005).

A teoria do ciclo de produtos elaborada por Vernon (1972) é outra vertente teórica do comércio de produtos industrializados. Para Vernon, a inovação de produtos ocorre nas economias mais desenvolvidas, uma vez que a demanda surge onde as rendas são mais altas e os gostos mais sofisticados, além do fato de que a alta especialização da mão-de-obra possibilita vantagens comparativas ao desenvolvimento e à produção inicial (Appleyard \& Field, 1998).

Vernon (1972) argumenta que a predisposição de um país para desenvolver novos produtos não é uma simples questão de oportunidade. A fim de que inovações sejam realizadas, há a necessidade da disponibilidade de mão-de-obra qualificada, além de empresários interessados em concentrar esforços naquilo que presumem ser a demanda. Dessa maneira, eles produzirão os bens que já possuem demanda no mercado local. Assim, a partir do momento em que a demanda por esses novos produtos se tornar internacional, o país os exportará. Contudo, o local de produção irá migrar para países menos desenvolvidos, à medida que a produção desses bens deixar de utilizar a tecnologia de ponta, sendo, então, exportado para os países mais ricos.

As principais conclusões de Vernon divergem tanto do modelo de Heckscher-Ohlin quanto com o de Linder (1961), ao prever um padrão de comércio independente da semelhança de fatores, no qual grande parte do comércio é intraindustrial, o que explica as transações de grandes quantidades de bens que apresentam características semelhantes.

Apesar de os modelos de comércio de produtos industrializados explicarem pontos que até então eram contraditórios à economia internacional, esses ainda não têm o mesmo poder explicativo para questões como as propostas por Porter (1989):

A questão mais geral é: por que as empresas de determinadas nações estabelecem uma liderança em certas indústrias novas? O que acontece quando a demanda se origina simultaneamente em diferentes países, como é comum hoje? [...] Por que a inovação é contínua em muitas indústrias nacionais e não um acontecimento que se realiza de uma só vez, seguida pela inevitável padronização da tecnologia, como a teoria do ciclo do produto diz? [...] Como explicar por que as empresas de certos países podem manter a vantagem numa indústria e outras não podem? (Porter, 1989, p. 18). 


\subsubsection{Teoria de Vantagem Competitiva das Nações}

Porter (1989) contesta, em sua obra A Vantagem Competitiva das Nações, as teorias clássicas, propondo uma nova abordagem, que vai além do conceito de vantagem comparativa, concentrando-se na vantagem competitiva dos países e abordando o conceito de competição, que inclui mercados segmentados, produtos diferenciados, diversidades tecnológicas e economias de escala. A questão central que o autor analisa nessa obra é o porquê empresas baseadas em determinadas nações atingem sucesso internacional em segmentos e indústrias distintos.

Para Porter (1999), a produtividade é o conceito primordial da competitividade nacional, sendo que a prosperidade econômica das empresas e dos países está vinculada à produtividade com a qual os recursos nacionais (trabalho e capital) são empregados. O nível de renda per capita de um país e do padrão de vida é determinado, principalmente, pela produtividade. Assim, a capacidade das empresas de um determinado país atingir altos níveis de produtividade e aumentá-la com o tempo determina o padrão de vida do país.

Assim como o capital, os recursos humanos de um país são limitados. As nações não podem ser competitivas em tudo. O importante é que os recursos sejam aplicados nas atividades mais produtivas, obtendo, através do comércio, ganhos de produtividade para a nação. A produtividade de um país sofre grande impacto pela integração comercial com outros países. Este princípio, defendido por Porter (1989), foi descrito também por Smith (1985) e Ricardo (1982).

\footnotetext{
O comércio internacional permite ao país aumentar sua produtividade, eliminando a necessidade de produzir todos os bens e serviços dentro do próprio país. Com isso, a nação pode especializar-se nas indústrias e segmentos nos quais suas empresas são relativamente mais produtivas e importar os produtos e serviços em relação aos quais suas empresas são menos produtivas do que as rivais estrangeiras, aumentando dessa forma a produtividade média da economia. As importações, portanto, bem como as exportações são parte integrante do crescimento da produtividade (Porter, 1989, p. 07).
}

Porter (1989) argumenta que o comércio internacional pode, por outro lado, ameaçar o crescimento da produtividade, uma vez que as firmas, acostumadas aos padrões de competitividade nacional, poderiam ser derrotadas se não forem competitivas internacionalmente, o que comprometeria a sua capacidade de exportação e o padrão de vida do país.

O autor ainda afirma que a obtenção de um saldo comercial positivo, ou mesmo um comércio equilibrado não significa que o país seja competitivo, uma vez que o aumento das 
exportações geradas por baixos salários e a uma moeda fraca acarreta em redução do nível de vida do país. Para o autor, ao invés de se preocupar com o excedente comercial, o país deve buscar exportar bens fabricados com alta produtividade, o que acarreta em maior produtividade nacional e, portanto, aumento de renda per capita.

Ao contrário do pensamento predominante, que associa vantagens competitivas aos custos da mão-de-obra, às taxas de juros, às taxas de câmbio e às economias de escala, o aumento da produtividade ocasionado por meio de inovações, tecnologias de ponta, qualificação de mão-de-obra e aprimoramento de processos produtivos e gerenciais é o que gera essas vantagens (Porter, 1989). Portanto, para que um país obtenha e mantenha um alto padrão de vida é necessário que atinja uma boa produtividade, além de um ritmo de crescimento dessa produtividade. Ou seja, uma elevada renda per capita está relacionada com a frequência de inovações na economia. Logo, a teoria de Porter sobre a vantagem competitiva das nações foi construída com base no caráter dinâmico do capitalismo, decorrente de inovações.

\subsection{Determinantes da Vantagem Competitiva}

Através de inúmeras pesquisas sobre as nações e indústrias, Porter (1989) identificou os principais determinantes da vantagem competitiva numa indústria. $\mathrm{O}$ autor analisa como esses determinantes atuam conjuntamente e os papéis que exercem em uma nação. Com isso, sua teoria não apenas ressalta o valor da inovação, mas também descreve os atributos necessários para que o país incentive suas empresas a inovar.

Segundo o autor, são quatro determinantes que modelam o ambiente nacional, possibilitando vantagens competitivas das empresas para o êxito internacional numa determinada indústria (Porter, 1989, p. 87):

I. Condições de fatores: a posição do país nos fatores de produção, como trabalho especializado ou infraestrutura, necessários à competição em determinada indústria.

II. Condições de demanda: a natureza da demanda interna para os produtos ou serviços da indústria.

III. Indústrias correlatas e de apoio: a presença ou ausência de indústrias correlatas e fornecedoras que sejam internacionalmente competitivas. 
IV. Estratégia, estrutura e rivalidade das empresas: As condições, no país, que determinam como as empresas são criadas, organizadas e dirigidas, mais a natureza da rivalidade interna.

Esses determinantes formam o chamado Diamante Nacional, apresentado pela Figura 2:

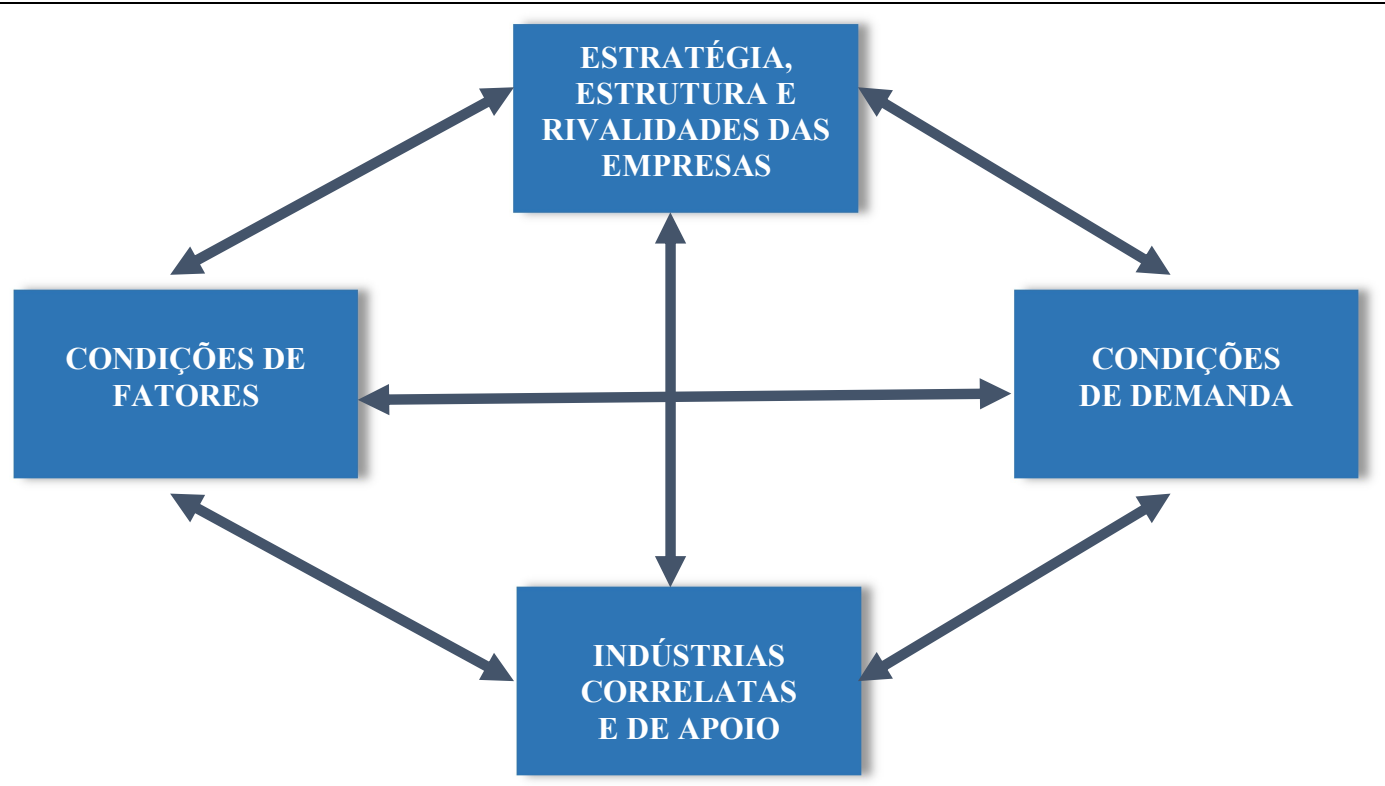

Figura 2 - Diamante de Porter

Fonte: Porter (1989, p. 88)

A teoria da vantagem competitiva agrupa os fatores nas categorias: recursos humanos, recursos físicos, recursos de conhecimento, recursos de capital e infraestrutura. Em um país, as empresas alcançam vantagem competitiva ao obterem fatores de baixo custo ou de qualidade excepcional, além da eficiência e efetividade com que são distribuídos. Vale a distinção entre os fatores herdados pelo país, assim como os recursos naturais ou a localização, ou aqueles criados por ele. Para que a vantagem competitiva seja mantida, os fatores mais importantes precisam ser criados.

As empresas conseguem vantagem competitiva quando é possível a acumulação rápida de bens e práticas especializadas, o que pode ser resultado apenas de um maior empenho. Além disso, a obtenção de vantagens competitivas ocorrerá, principalmente, em indústrias nas quais a base nacional possibilita o acesso a maiores informações e percepções permanentes das necessidades de produtos e processos. Outro aspecto relevante para a obtenção da vantagem competitiva é o estabelecimento de metas para empenho intenso e um investimento 
contínuo. Em última análise, o ambiente nacional, dinâmico e desafiador, estimula as indústrias a se aperfeiçoarem, ampliando suas vantagens, no decorrer do tempo (Porter, 1989).

Assim, os países têm maior probabilidade de obter êxito em indústrias ou segmentos de indústrias onde o "diamante" do país é o mais favorável.

Enquanto os modelos de Ricardo e Heckscher-Ohlin são estáticos, uma vez que a produtividade do trabalho ou o estoque de fatores (mão-de-obra, território, recursos naturais, capital e infraestrutura) são dados e determinam o fluxo do comércio, o modelo de Porter acredita na criação de fatores, sendo que a competitividade de um país ou de uma indústria depende da capacidade de criar, inovar e melhorar continuamente.

Assim, inovar e mudar são fundamentais na competição real. Ao invés de transferir passivamente os recursos para os pontos onde os rendimentos são maiores, as empresas devem aumentar os rendimentos através da inovação de produtos e processos. Em lugar de buscar a maximização dentro de limites fixos, as empresas devem buscar vantagem competitiva mudando esses limites. E, a questão mais relevante é como empresas e países podem melhorar a qualidade dos fatores e, consequentemente, aumentar a produtividade dos mesmos e não apenas distribuir um total fixo de fatores de produção. (PORTER, 1999).

Assim como Linder (1961), Porter (1989) justifica que a demanda interna é fundamental na definição do fluxo do comércio internacional: "A teoria de Linder esclarece a importância que a demanda local tem para o comércio e o fato de que as semelhanças amplas de demanda são necessárias para o comércio" (Porter, 1989, p.153).

Porter (1989) defende que a demanda interna é fundamental para a construção da vantagem competitiva, uma vez que, com uma demanda mais sofisticada e exigente, as empresas enfrentam mais dificuldades para conquistar consumidores, o que gera a necessidade de constante aprimoramento do produto. Além disso, se as necessidades de um país têm o potencial de se tornarem necessidades mundiais, as empresas localizadas nesse mercado poderão obter vantagens competitivas na produção, antecipando-se às demais.

A terceira determinante da vantagem nacional numa indústria está atrelada à presença de indústrias fornecedoras e de indústrias correlatas que detenham vantagens competitivas internacionais. Isso ocorre porque à medida que uma empresa obtém seus insumos a custos reduzidos e de maneira eficiente, as indústrias interdependentes se tornam mais eficientes e mais competitivas (Coutinho et al., 2005). A presença de indústrias competitivas correlatas no país leva a novas indústrias competitivas, pois oferece oportunidades de informação e intercâmbio técnico. 
Além disso, fornecedores internos têm grande relevância no processo de inovação e aperfeiçoamento. Os fornecedores podem ajudar as empresas a descobrir novos métodos e oportunidades de aplicar novas tecnologias. As empresas têm a oportunidade de influenciar os esforços técnicos dos fornecedores, bem como servir como local de testes para o trabalho de desenvolvimento, o que facilita o acesso às informações, às novas ideias e conhecimentos e às inovações do fornecedor. Tal intercâmbio pode gerar resultados mais eficientes. (Porter, 1989).

O quarto determinante do diamante nacional está na conjuntura na qual as firmas são constituídas, organizadas e dirigidas, bem como no padrão de rivalidade interna. As estratégias e as estruturas das empresas dependem de circunstâncias nacionais, o que resulta em vantagens competitivas em indústrias especifica para cada país.

E qual é o papel do governo para a vantagem competitiva nacional? Porter apresenta o papel do governo como a variável final para os determinantes da vantagem competitiva nacional. O governo é capaz de influenciar a estrutura da estratégia das empresas e a rivalidade interna. Além disso, as condições dos fatores são influenciadas pelas políticas de educação, políticas de aprimoramento do mercado de capitais, políticas de subsídios, entre outras. O governo, ao que parece, pode apressar ou aumentar as probabilidades de obter vantagem competitiva (e vice-versa), mas falta-lhe o poder de criar a própria vantagem (Porter, 1989). O autor destaca que "as políticas governamentais bem-sucedidas são aquelas que criam um ambiente em que as empresas são capazes de ganhar vantagem competitiva, e não aquelas que envolvem o governo diretamente no processo" (Porter, 1989, p. 197).

O Estado não pode criar indústrias competitivas; as empresas, sim. O papel do governo na competição é, inerentemente, parcial, porque muitas outras características do país a influenciam. O governo pode modelar (ou influenciar) o contexto e a estrutura institucional que cercam as firmas, bem como os insumos utilizados. O volume e a qualidade das informações disponíveis num país são de crescente importância na competição internacional moderna. As informações representam um meio de superação da inércia e criação de um senso de premência nas empresas (Porter, 1989). As informações sobre mercados, tecnologia e competição determinam as decisões das empresas, focalizam novas necessidades e oportunidades e mostram as ameaças (Porter, 1989). Assim, o Estado tem papel destacado, na maioria dos países, na expansão do estoque de informações disponíveis para as empresas ao fornecer elementos como estatísticas governamentais e outras publicações, bem como regulamentos sobre a informação. De igual importância na criação de informação é a 
disseminação. Políticas governamentais de intensificação e divulgação da informação ajudam o aprimoramento da indústria (Porter, 1989).

Com isso, enquanto as teorias tradicionais de comércio internacional abordam o problema de forma estática, a teoria de vantagem competitiva das nações tem uma visão dinâmica.

Apesar de também afirmar que a produtividade é a principal determinante do fluxo de comércio internacional, Ricardo, ao contrário de Porter, considera o trabalho como o único fator de produção, importando apenas a produtividade deste.

Já para Porter, é a produtividade do conjunto de diversos fatores de produção que determina em quais indústrias um país terá vantagem competitiva. A diferença marcante entre as duas teorias é que Ricardo enfoca a produtividade como um dado, enquanto Porter a enfoca de maneira dinâmica tornando-a suscetível de ser criada por meio de melhorias e inovações.

A disponibilidade de fatores é importante tanto na teoria de Heckscher-Ohlin quanto na de Porter. Contudo, enquanto, para Heckscher-Ohlin, essa disponibilidade tem o papel central na determinação do fluxo de comércio, ou seja, quanto maior a disponibilidade relativa do país em um fator maior será sua vantagem comparativa na produção desse bem e, logo, sua exportação do mesmo, para Porter o comércio é determinado pela produtividade. Para esse autor, a dotação de fatores é apenas um dos quatro determinantes do diamante nacional que podem levar à vantagem competitiva. Ao contrário de Heckscher e Ohlin, argumenta que o país terá condições de exportação somente dos produtos produzidos com abundância de fatores com maior disponibilidade relativa interna, Porter defende que a escassez de fatores pode ser um impulsionador capaz de levar a empresa a inovar, a fim de enfrentar a dificuldade, alcançando através disso a vantagem competitiva que poderá acarretar na exportação em outro momento.

A teoria de Heckscher e Ohlin sugere políticas governamentais de comércio internacional que diferem significativamente das aconselhadas por Porter. Enquanto aquela sugere a interferência direta, esta defende políticas de fomento por meio de investimento na qualificação da mão-de-obra e em pesquisa e desenvolvimento, além do incentivo à concorrência interna. Assim, as políticas governamentais devem abordar a criação de condições que facilitem e estimulem a inovação.

Conclui-se, portanto, que a base da argumentação de Porter encontra respaldo nas teorias econômicas já consagradas. Seu ponto de vista assemelha-se ao de Ricardo quanto à ênfase na produtividade como razão da vantagem competitiva, à teoria de Heckscher e Ohlin 
em relação à importância dos de fatores, e às teorias de Linder e Vernon pelas condições da demanda.

\subsection{Internacionalização de Empresas}

$\mathrm{Na}$ literatura econômica, o conceito de internacionalização de empresas é definido como sinônimo de cooperação econômica internacional e muitas vezes entendido como globalização. Algumas correntes de análise, sejam administrativas ou econômicas, entendem a internacionalização como o processo de inserção internacional realizada por investimentos diretos (Cintra \& Mourão, 2005). Entretanto, o investimento direto estrangeiro não incorpora os mais diversos métodos pelos quais as empresas participam em operações fora de seu país de origem, os quais envolvem diversos tipos de empreendimento de colaboração e diferentes modos de coordenação e controle de transações, que incluem relações contratuais e fluxos comerciais de exportação e importação (Dickens, 2010). Apesar da relevância para estudos sobre multinacionais com produção no exterior, a compreensão da internacionalização através da inserção por investimentos (Dunning \& Lundan, 2008) é restrita, uma vez que não incorpora todas as complexidades, níveis e maturidade do processo (Coelho, 2014). Considera-se, neste estudo, que a análise da internacionalização deve ser capaz de incorporar todas as complexidades, níveis e maturidade do processo. Assim, definições mais abrangentes, como a de Brasil et al. (1996, p. 11), que determina a internacionalização como "um processo crescente e contínuo de envolvimento de uma empresa nas operações em outros países fora de sua base de origem", a definição de Cyrino e Barcellos (2006, p.224), que entende a "internacionalização como movimento das empresas além das fronteiras de seu país de origem", ou ainda Welch e Luostarinen (1999, p.84) que apresentam a internacionalização como "o processo de crescente envolvimento em operações internacionais", estão mais alinhadas com este estudo.

A internacionalização comercial não é um fenômeno propriamente novo. Sua origem regressa ao período Mercantilista, que teve seu marco no século XV, com a Revolução Comercial, que ficou famosa pelos grandes descobrimentos marítimos e pela abertura de novas rotas comerciais. Contudo, foi após a Segunda Guerra Mundial que esse processo apresentou um grande crescimento, uma vez que os Estados Unidos passaram a focar no comércio internacional para a expansão de negócios, aproveitando a crescente demanda 
mundial por conta, principalmente, da devastação bélica (Silva Júnior \& Rodrigues, 2002). Ou seja, o fenômeno é recente, mas tem contornos bem definidos.

Depois da Segunda Guerra Mundial, com a criação de instituições de apoio às nações, primeiramente o GATT - Acordo Geral Sobre Tarifas e Comércio, houve uma crescente queda nas barreiras comerciais, gerando um aumento na evolução das trocas internacionais. As tarifas de importação caíram de uma média de 50\%, em 1948, para aproximadamente 2,5\%, nos dias de hoje, apesar da existência de picos tarifários em muitos países, principalmente nas nações industrializadas (Silva Júnior \& Rodrigues, 2002).

Segundo Yip (2001, p. 347), “Globalizar ou não globalizar - ou seja, internacionalizar - têm se tornado duas das mais calorosas questões estratégicas para os gerentes no mundo todo". Globalizar é mais do que fazer negócios em um determinado número de países, envolve fazer negócios em todo o mundo, de uma nova maneira, equilibrando as qualidades dos seus produtos e serviços com as necessidades específicas das diversas bases de clientes locais (Daniels, Daniels, \& Liske, 1996). A decisão de explorar novos mercados geográficos implica drasticamente no modo operacional das empresas (Cyrino \& Penido, 2007). A iniciativa de operar fora das fronteiras domésticas tem sido abordada por alguns autores como uma das decisões estratégicas ao lado das decisões de diversificação (Ansoff \& Mcdonnel, 1993 ) e, por outros, como um ato de empreendedorismo (Anderson, 1990), dados os riscos e os benefícios potenciais envolvidos.

Os motivos que levam à internacionalização de empresas não são apenas de ordem econômica (Aliber, 1983; Teece, 1985), mas também derivados das necessidades estratégicas e da dinâmica do crescimento das empresas (Dunning \& Rugman, 1985). Relacionam-se à expectativa de aumento de ganhos, melhoria da lucratividade e do seu valor de mercado através dos benefícios esperados por tal estratégia, que se vinculam a questões econômicas, de mercado, transacionais, comportamentais, ou governamentais (Cyrino \& Penido, 2007; Unctad, 2006; Cyrino et al., 2010). Esses motivadores podem ser entendidos como os fatores que desencadeiam ou intensificam o processo de internacionalização das empresas, normalmente tratados a partir de suas características locais, isto é, de seu país de origem (push factors), ou daqueles do destino (pull factors) (Unctad, 2006). Dentre os principais motivadores da internacionalização destacam-se a busca de maior controle sobre os canais de distribuição e do contato com o cliente final, proximidade dos seus principais clientes nas regiões onde estão presentes (cliente-following), busca de ativos importantes para o sucesso competitivo, superação de barreiras tarifárias, pressão da concorrência global, busca de economia de escala, aprendizado e desenvolvimento de competências para operar em novos 
mercados internacionais e saturação do mercado doméstico (Cyrino et al., 2010). Adicionamse, ainda, no contexto recente, um terceiro grupo (policy), relacionado às políticas governamentais em particular as políticas de incentivos à internacionalização, sejam na saída (outward), ou na entrada (inward) de capital e fatores produtivos.

A escolha de ingresso em mercados internacionais vem acompanhada por maiores riscos e incertezas (Hymer, 1976), quando comparados à decisão de expandir geograficamente no mesmo território (Cyrino \& Penido, 2007). Desta maneira, o que se observa é que as empresas tendem a esgotar as suas possibilidades de crescimento nos mercados de origem, antes de partirem para o exterior, sendo que apenas empresas que já desenvolveram vantagens competitivas significativas no mercado interno são capazes de alavancá-las no mercado estrangeiro (Haussmann, Holtbrügge, Rygl, \& Schillo, 2006).

Cyrino et al. (2010), agruparam em três grandes categorias as dificuldades e obstáculos à internacionalização das empresas: (i) barreiras internas, que dizem respeito à adequação das capacidades e recursos das empresas para atuarem em mercados internacionais; barreiras situadas no ambiente competitivo do país de origem, relacionadas à adequação da infraestrutura econômica e institucional à oferta de fatores e a atitudes e características culturais; barreiras situadas nos mercados de destinos, também de natureza econômica, político-institucional e cultural.

\subsubsection{Oportunidades e Ameaças da Internacionalização das Empresas}

A empresa, em um mercado internacional, encontra-se com concorrentes de seu mercado doméstico e com concorrentes de cada país em que atua. Alguns desses concorrentes serão conhecidos, enquanto outros serão encontrados pela primeira vez (Bradley, 1995). O padrão de competição internacional difere de indústria para indústria, assumindo num extremo a forma multi-doméstica - ou seja, a competição é independente em cada país - e, em outro extremo, a forma global (Porter, 1993).

Os concorrentes, em geral, não representam apenas ameaças à empresa, mas também um estímulo, em muitas indústrias, à posição competitiva, uma vez que a presença de concorrentes certos pode produzir uma variedade de benefícios estratégicos que se enquadram em quatro categorias gerais: ampliar a vantagem competitiva, melhorar a atual estrutura industrial, ajudar no desenvolvimento do mercado e deter a entrada de novos entrantes (Porter, 1990; Hausmann et al., 2006; Fleury A \& Fleury M, 2007). Bradley (1995) também 
afirma que a concorrência tem efeitos positivos e negativos a serem considerados. Tais efeitos atingem o mercado e a própria empresa, porém, se monitorados e gerenciados, podem trazer benefícios. A busca pela qualidade dos produtos é um dos fatores positivos. Com a concorrência, o consumidor torna-se mais exigente e força os fabricantes a buscarem melhores tecnologias para produzirem melhores produtos. Além disso, a presença de concorrentes ressalta as vantagens competitivas da empresa.

\subsubsection{Benefícios, Riscos e Custos da Internacionalização.}

Ghemawat (2001) defende que a decisão de internacionalizar se situa conceitualmente entre dois opostos extremos: considerando a convergência dos mercados como resultado da globalização, a internacionalização seria como a entrada em mais um território já conhecido, enquanto considerando que os mercados são puramente locais, isto é, diferentes entre si, a decisão de internacionalizar implica um ato de alto risco, diante da inviabilidade de lançar mão dos ativos e das competências já desenvolvidos no país de origem.

Desta maneira, a decisão de internacionalizar está marcada pela tensão existente entre a tendência de reproduzir o já conhecido em outros contextos e a de criar soluções próprias para as características de cada mercado (Cyrino \& Penido, 2007). Assim, o sucesso das empresas no plano internacional depende da sua capacidade de conciliar as duas forças opostas: a de maximizar as vantagens compensatórias oriundas da base de ativos e dos conhecimentos desenvolvidos nos mercados em que atua, e a de estabelecer uma nova configuração de competências, adaptada a circunstâncias e características locais e explorá-las numa escala global (Buckley \& Casson, 2002).

Diferentes benefícios e riscos associados à diversificação internacional de mercados são apresentados pela literatura sobre a internacionalização (Hymer, 1976). Os benefícios que uma empresa abre mão, ou os riscos que ela assume, dependem de muitos fatores, destacandose entre eles o estágio em que a empresa se encontra no processo de internacionalização, sua localização na cadeia produtiva, o setor em que ela compete e as características do contexto econômico e institucional da sua base doméstica e nos mercados potenciais onde ela pretende atuar. A internacionalização pode, assim, ser vista como resultado da imperfeição de mercado, o que torna a coordenação das atividades de produção internas na empresa, mais vantajosa do que mediá-las nos mercados (Hymer, 1976). As firmas podem se internalizar no mercado por meio de investimentos diretos no exterior. Neste caso, a empresa evita custos de acordos, o 
que inclui a supervisão de preço, do output ou a perda de lucratividade e da vantagem competitiva. Essa situação ocorre, principalmente, quando há monopólios ou mesmo oligopólios, sendo assim, o controle do processo fundamental para a redução da competição e para que ocorra a apropriação completa do emprego de um ativo específico (Hermais \& Hilal, 2004). Outra opção é a externalização via licenciamento, que é mais comum para os casos de mercado com características de competição perfeita. Apesar de muitas empresas iniciarem suas operações por licenciamento, Hymer (1983) destaca que não há um modo predefinido para essa tomada de decisão, uma vez que os mercados são imperfeitos, e as empresas apresentam características próprias.

Os benefícios da expansão internacional são inúmeros, destacando-se (Chudnovsky \& López, 2000; Garrido, 1999, 1999; Kosacoff, 1999; FDC, 2012; Cyrino \& Penido, 2007): (i) expansão de mercados; (ii) melhoria de eficiência; (iii) aprendizagem; (iv) aumento do valor da marca pela presença internacional; (v) capacidade ampliada de atendimento a clientes globais; (vi) diferenciação perante concorrentes domésticos ou menos internacionalizados; (vii) melhoria da imagem da empresa no mercado doméstico; (viii) capacitação de inovação tecnológica potencializada; (ix) desenvolvimento de equipes com habilidades multiculturais; (x) busca de fundos através do acesso a mercados de capital internacionais; (xi) desenvolvimento de novos produtos e segmentos; (xii) melhoria do desenvolvimento econômico financeiro; (xiii) redução do risco do negócio por não estar exposto a um único mercado consumidor; (xiv) redução de custos através de economias de escala e de escopo; (xv) acesso a novos mercados com forte crescimento econômico; (xvi) aumento da competitividade da empresa frente a players internacionais; (xviii) proteção da base de clientes; (xix) economia de custos com melhor planejamento tributário.

A expansão de mercado é uma das principais causas para a expansão e a diversificação internacional de uma empresa. Isso ocorre quando as perspectivas de crescimento no país de origem já não são mais atrativas o suficiente para assegurar os retornos desejados pelos acionistas, ou então a empresa identifica oportunidades de negócios mais interessantes para a aplicação dos seus ativos no exterior (Cyrino \& Penido, 2007).

A presença em múltiplos mercados internacionais propicia a empresa vantagens como:

a. Maior capacidade de resposta aos clientes internacionais - uma vez que a presença da empresa em mercados internacionais facilita a compreensão das necessidades dos clientes estrangeiros, bem como dos clientes nacionais com presença em outros países; 
b. Fortalecimento da posição competitiva - a presença física da empresa nos mercados internacionais leva a um melhor entendimento da concorrência local e estrangeira;

c. Diversificação do portfólio geográfico e redução de riscos - a decisão de internacionalizar pode ser encarada como uma tentativa de obter um portfólio geográfico de risco-retorno mais equilibrado, reduzindo, com isso, a dependência do país de origem. Esses riscos, entre outros, incluem os políticos e econômicos de cada país, envolvendo deste a imposição de taxas excessivas e restrições legais onerosas, por parte das autoridades do país, até a quebra de contratos, expropriação de ativos físicos, confisco ou risco de não transferência de divisas, fenômenos adversos da natureza, guerras e distúrbios civis (Cyrino \& Penido, 2007). Morck e Yeung (1991) afirmam que empresas listadas em bolsas de valores apresentam um aumento no valor de mercado, uma vez que para os investidores, a presença em diferentes países reduz a percepção de risco.

d. Efeito de demonstração - isso ocorre com frequência em países emergentes, cujos consumidores são muito influenciados por produtos importados e marcas estrangeiras. Além do orgulho nacionalista de ter uma empresa que está operando em mercados internacionais, há o efeito da transferência do sucesso no exterior.

Quanto à melhoria da eficiência, ela ocorre porque as empresas são capazes de atingir novos patamares, com a expansão internacional, em decorrência dos ganhos de escala e escopo, bem como da possibilidade de acesso a fatores de produção a custos mais acessíveis. Isso ocorre, devido a vantagens como:

a. Economias de escala e escopo - exemplos são encontrados na indústria de aviação e indústria química, nas quais a internacionalização é um caminho inevitável para as indústrias que se situam em mercados globais.

b. Acesso a recursos escassos e/ou a custos inferiores - otimização da cadeia de suprimentos em escala global e na busca do acesso a recursos e insumos a custos mais favoráveis (Cyrino \& Penido, 2007).

c. Ganhos de arbitragem - diferenças nos custos de insumos e preços entre os diversos países em que as multinacionais operam, possibilitam a realização de operações lucrativas para as mesmas (Kogut, 2002). Isso porque a presença em 
diversos mercados possibilita que essas empresas movam suas produções, explorarem regimes tributários favoráveis, reajam a mudanças nas taxas de câmbio e transferiram conhecimentos e know-how de uma localidade para outra, reagindo mais rapidamente a ameaças e oportunidades.

No que tange à aprendizagem, a diversificação da base de conhecimentos adquiridos pela exposição a situações diferentes nos diversos mercados em que a empresa atua é um dos ganhos decorrentes do processo de internacionalização (Welge \& Holtbrügge, 2003). As diversas soluções que uma empresa precisa desenvolver como resposta a problemas locais nos mercados internacionais se incorporam ao repositório de conhecimentos dos quais a empresa pode lançar mão quando se defronta com situações semelhantes em novos países. O acúmulo dessas experiências leva a um upgrade das competências da empresa como um todo, permitindo, inclusive, a melhoria da produtividade e qualidade nos mercados domésticos (Haussmann et al., 2006). A aprendizagem no novo mercado leva as seguintes vantagens:

a. Acumulação de conhecimento, desenvolvimento e aperfeiçoamento das competências existentes - a empresa é capaz, à medida que se expande em novos mercados geográficos, aproveitar os conhecimentos e capacidades desenvolvidos nos mercados de origem, bem como incorporar novas experiências com mercados internacionais (Johanson \& Vahlne, 1977). No âmbito da expansão internacional, esse efeito reproduz o clássico efeito da curva de experiência ou curva de aprendizado, aplicado ao nível da produção. Quanto mais os repertórios de soluções e experiências vão se integrando na base de conhecimento e ativos da empresa, mais esta pode tirar partido dessa diversidade para solucionar os problemas decorrentes da entrada em novos países.

b. Alavancagem das competências empresariais atuais a novos produtos e segmentos - nos mercados internacionais, as empresas são obrigadas a encontrar soluções inovadoras para o atendimento das características próprias dos mercados, que muitas vezes são bem diferentes do portfólio de produtos originais.

c. Desenvolvimento e aquisição de novas competências empresariais - a expansão internacional pode servir como uma busca consciente de criação de novas competências e conhecimentos, não disponíveis e/ou valorizados no mercado de origem (Haussmann et al., 2006). Muitas empresas europeias e asiáticas de 
informática procuram localizar-se nos clusters tecnológicos, como o do Vale do Silício ou do Research Triangle, a fim de se capacitarem no uso de novas tecnologias (Cyrino \& Penido, 2007). Muitas vezes, é parte da estratégia de internacionalização da empresa buscar as tendências emergentes nos mercados mais exigentes e os desenvolvimentos tecnológicos nos centros mais desenvolvidos para que ela possa, internacionalizando-se, ou por meio de novas alianças, incorporar esse aprendizado na forma de novos produtos (Doz \& Santos, 2001).

Quanto aos custos e riscos mais importantes do processo de internacionalização, podese dizer que são: (i) custos crescentes de coordenação e governança; (ii) desvantagem do recém-chegado (liability of newness); (iii) desvantagem de ser estrangeira (liability of outsidership); e, (iiii) riscos políticos e econômicos dos mercados internacionais.

Com o crescimento do nível de diversificação geográfica de empresas, surge a necessidade de maiores investimentos em mecanismos de processos de coordenação e de gestão do seu portfólio de atividades internacionais. A crescente complexidade e a diversidade das operações internacionais impõem uma sobrecarga aos recursos existentes - deslocamento de profissionais expatriados, atenção gerencial às novas operações - e exigem novos recursos especializados - na forma de estruturas e processos de controle, contribuindo, no final das contas, para o aumento dos custos gerais de coordenação e governança da empresa (Welge \& Holtbrügge, 2003). Quanto maior a expansão internacional de uma empresa, maior será a intensidade nos esforços de comunicação, nos processos de planejamento e coordenação entre as diversas subsidiárias, dificultados, naturalmente, em função da distância.

Por outro lado, ao se instalar em uma nova localidade, independentemente se é ou não internacional, a empresa se defronta com os custos de ser nova no mercado (Hymer, 1976; Stinchcombe, 1965 apud Cyrino \& Penido, 2007). Estes custos, em geral, são decorrentes de se instalar no local, encontrar e recrutar pessoas e gerentes, negociar com fornecedores, adquirir acesso aos canais de distribuição, formar a base de clientes e se enquadrar no esquema regulatório legal (Zaheer \& Mosakowki, 1997).

Esse início coloca uma subsidiária em desvantagem com relação aos seus concorrentes locais já instalados, não só em termos de desembolsos iniciais (já amortizados pelos concorrentes instalados), mas também na curva de aprendizagem e de experiência local (na qual os competidores locais estão mais avançados). Quando uma empresa instala uma operação greenfield no exterior, estes custos de "recém-chegada" são mais elevados. Outros 
modos de entrada reduzem o custo da novidade. Assim, a aquisição de uma empresa local no país estrangeiro, ou a aliança com empresas locais, pode superar os obstáculos de ser novo no mercado, embora tenha outros impactos que devam ser levados em consideração (em particular, o maior custo de controle e de governança associados a essas modalidades).

Já a desvantagem de ser estrangeiro trata do desconhecimento e da dificuldade de lidar com diferentes mercados e culturas muito diferentes daquelas do país de origem (Hymer, 1976). Um dos maiores obstáculos da expansão transfronteiriça é a distância entre o país de origem e o país de destino, em relação às diferenças administrativas, culturais, econômicas, físicas e geográficas (Ghemawat, 2003). Os custos da aprendizagem internacional são muito grandes no início e se reduzem à medida que a empresa aprende a operar negócios no novo mercado.

As empresas podem reduzir os níveis dos custos de ser estrangeiro, buscando, inicialmente, mercados internacionais mais semelhantes aos do país de origem, mesmo que sejam economicamente menos interessantes. De fato, a trajetória das empresas brasileiras mostra que elas, em geral, iniciaram as suas operações internacionais em países da América Latina, antes de ingressar em mercados mais maduros (Cyrino, Penido, \& Tanure, 2005).

Em geral, os clientes e a comunidade de negócios associam alguns estereótipos, nem sempre positivos, ao país, que contaminam a empresa e que custam a ser desfeitos, mesmo quando a empresa se destaca por sua excelência. Cyrino e Penido (2007) destacam que muitas empresas brasileiras estão engajadas em um grande esforço de marketing empreendido para desfazer alguns preconceitos associados ao Brasil, por exemplo.

Já o risco político e econômico do mercado deve ser muito bem avaliado, tanto na escolha do mercado, como na operação das subsidiárias internacionais. Muitos mercados que são economicamente interessantes para as multinacionais de países emergentes, por causa da sua instabilidade, podem comprometer a rentabilidade das operações e, em alguns casos, ocasionar perdas significativas (Cyrino \& Penido, 2007).

\subsubsection{Teorias de Internacionalização}

O processo de internacionalização apresenta decisões intrínsecas, que são: escolha de país, escolha de estrutura de controle, programação e sequência de investimentos, escolha dos produtos a serem produzidos no exterior, escolha do processo a ser utilizado, transferência de 
conhecimento, logística e suprimento de fábrica, modelo de gestão, coordenação geral e sistema de fábricas no exterior (Fleury \& Fleury, 2007).

Uma revisão da literatura desenvolvida sobre o tema revela a gradual emergência de diferentes perspectivas, que analisam o processo de internacionalização da empresa como um todo. Edith Penrose foi pioneira no estudo sobre a internacionalização das empresas. Em seu artigo de 1956, Foreign Investment and the Growth of Firm, Penrose realiza um estudo de caso da subsidiária da General Motors na Austrália, analisando os ganhos de capital obtidos com a criação da subsidiária, e mostrando que a empresa foi além do estabelecimento de uma fábrica de automóveis naquele país, diversificando suas atividades e ingressando em outros ramos industriais, não apenas por dispor dos recursos financeiros, mas também pela existência de condições favoráveis no mercado australiano e, principalmente, devido à disponibilidade e aproveitamento de recursos tecnológicos e administrativos, acumulados pela sua matriz nos Estados Unidos. Penrose (1956) argumenta, com esse exemplo, que o processo de estabelecimento de filiais no exterior ocorreu em decorrência do crescimento e diversificação das empresas industriais americanas, em sua maioria oligopolizadas nos seus respectivos mercados.

Penrose (1956) também fez considerações sobre o efeito para as políticas econômicas dos países em desenvolvimento das implicações dessa internacionalização produtiva das empresas. A autora considera que, apesar de esse investimento favorecer o desenvolvimento dos países hospedeiros, os ganhos dessa expansão só podem ser parcialmente apropriados por eles pela via tributária. Além disso, Penrose atenta para os custos macroeconômicos ocasionados pelos valores remetidos ao exterior, além de custos sociais e políticos atrelados à oligopolização de mercados locais e à progressiva subordinação das políticas nacionais de desenvolvimento aos interesses das empresas multinacionais.

Em seu artigo de 1960, The Growth of the Firm, publicado no Business History Review, Penrose apresenta os argumentos centrais da Teoria do Crescimento da Firma, apontando o desempenho da empresa como resultado de uma interação dos seus recursos produtivos e das suas oportunidades de mercado. Segundo a autora, os recursos produtivos (tecnológico, empresarial e administrativo) limitam ou determinam a expansão e diversificação da firma através do tempo. A firma expande suas fronteiras à medida que ela cresce, e o mesmo ocorre com suas responsabilidades administrativas. Logo, a taxa de crescimento da empresa é limitada pelo aumento do conhecimento nela existente, que permite inovações e diversificações, que ocasionam a expansão das suas fronteiras. 
Para Penrose, o crescimento de empresas multinacionais não é diferente da teorização para outras firmas:

\begin{abstract}
A literatura sobre o tema das firmas multinacionais tem crescido rapidamente desde meados do século XX, junto com a expansão das próprias empresas em suas diversas manifestações. Boa parte da análise do crescimento das firmas como a que apresentei parece de modo geral aplicar-se igualmente bem à expansão de investimentos externos diretos em sua forma contemporânea - nos quais os processos de crescimento, o papel do aprendizado, a teoria da expansão baseada em recursos internos, humanos e de outra natureza, o papel da administração, a diversificação da produção, o papel das fusões e das aquisições são todos importantes (Penrose, 2007, p.19).
\end{abstract}

Assim, mesmo reconhecendo as especificidades dos países, Penrose reitera que o processo de expansão das multinacionais pode ser compreendido através da estrutura teórica do crescimento da firma, sendo necessária apenas a adoção de alguns pressupostos "empíricos" para analisar a oportunidades e ameaças que não estão disponíveis para empresas que atuam em um único país.

Os pioneiros nos estudos voltados a internacionalização das empresas foram pesquisadores na área de Economia Internacional, que buscavam teorias que explicassem a racionalidade econômica do movimento das empresas que passavam a produzir no exterior. Os autores mais conhecidos deste grupo são John Dunning, da Universidade de Reading, na Inglaterra e Stephen Hymer. Suas primeiras publicações datam dos anos 1950 e 1960, respectivamente. A abordagem econômica parte do pressuposto de que as empresas se internacionalizam ou para explorar vantagens competitivas ou para internalizar transações que seriam menos eficientes ou mais caras se fossem feitas pelos mecanismos de mercado. $\mathrm{Ou}$ seja, prevalecem pressupostos racionais de decisões que buscam a maximização dos retornos econômicos (Dib \& Carneiro, 2006).

A segunda corrente, também conhecida por Escola Nórdica (Johanson \& Vahlne, 1977), enfatiza os aspectos comportamentais da internacionalização. Inspirada por trabalhos anteriores de "economistas comportamentais", especialmente Raymon e Vernon, esse grupo procurou lançar luzes sobre a questão da internacionalização como um processo no qual a aprendizagem organizacional assume o papel mais importante. Nas seções seguintes, serão analisados os principais representantes de cada uma dessas correntes. 


\subsubsection{A Teoria Eclética da Internacionalização da Firma}

A abordagem de racionalidade econômica foi sintetizada por John Dunning através do seu Paradigma Eclético (Dunning, 1988; 1993; 2000). Trata-se de uma abordagem pela qual se é possível identificar e ponderar os fatores significativos que influenciam tanto o ato inicial da produção no estrangeiro quanto o seu crescimento (Dunning, 2002). O autor estruturou o Paradigma por meio de frentes teóricas que, apesar de não explicarem separadamente o fenômeno da produção internacional, articuladas são capazes de interpretar as suas determinantes, extensão e padrões. Para responder as questões do por quê, para onde e quando se internacionalizar, Dunning baseou-se nas teorias da organização industrial, da localização, e do ciclo do produto de Vernon. O grande mérito de Dunning foi colocar em um único esquema analítico essas teorias independentes umas das outras Entretanto, de acordo com o próprio Dunning, o paradigma eclético não pode ser visto como algo que:

[...] ofereça uma explicação completa dos diversos tipos de produção internacional; e ser visto como algo que aponta para uma metodologia e para um conjunto genérico de variáveis que contém os elementos necessários para qualquer explicação específica de tipos particulares de atividades produtivas no exterior (Dunning, 1991, p.125).

O processo de internacionalização produtiva está vinculado, segundo Dunning (1977; 1988), ao aproveitamento das vantagens de propriedade, que são específicas das próprias firmas e dos países e que tornam possível explicar as atividades das empresas no exterior. O autor considerou a interação de três conjuntos de variáveis fundamentados em diversas correntes teóricas da Economia e Administração (Dunning, 2002). De acordo com o Paradigma Eclético, o que leva uma empresa a utilizar o investimento direto, ao invés de licenciamento ou exportação, são as falhas de mercado (custos de informação e transação, oportunismo dos agentes e especificidades de ativos). Segundo essa abordagem, para se internacionalizar, as empresas devem possuir certos tipos de vantagens sobre os seus competidores, que justifiquem o investimento direto no exterior. $\mathrm{O}$ paradigma admite três conjuntos de vantagens competitivas (Dunning, 2002):

a. Vantagens específicas de propriedade (ownership) - estão associadas a ativos tangíveis (como recursos naturais e mão-de-obra de baixo custo) e ativos intangíveis (como patentes, tecnologia, marca, imagem, habilidade para a diferenciação de produtos, capital humano, capacidade gerencial), ou seja, as capacidades próprias desenvolvidas pela organização, que lhe permitem se 
posicionar relativamente melhor no mercado estrangeiro quando comparada com os produtores locais ou outros produtores estrangeiros (Dunning, 2002);

b. Vantagens específicas de localização (location) - derivam de fatores relacionados à localidade onde vai ser implantada a operação internacional (Dunning, 2002). Essas vantagens são denominadas estruturais quando os fatores decorrem de condições locais que vão influenciar o desempenho da subsidiária (por exemplo, subsídios) ou transnacionais, quando, pelo fato de a empresa instalar operações num determinado país, ela modifica o processo de coordenação de ativos distribuídos por diferentes países e regiões (Dunning, 2002). Exemplos de vantagens de localização oferecidas pelos países são recursos naturais, mão-deobra, infraestrutura, ambiente institucional (sistema político-econômico e políticas públicas); incentivos e desincentivos ao investimento, tamanho do mercado, língua, entre outros (Dunning, 2002).

c. Vantagens específicas de internalização (internalization) - dizem respeito às possibilidades abertas à transferência de ativos entre países através da estrutura da empresa ao invés de utilizar os mecanismos do mercado. As vantagens de internalização são aquelas que indicam que, se os custos de incorporação e organização produtiva são inferiores aos custos de transação relacionados à transferência dessas capacidades a um terceiro, a firma investirá na produção nesse mercado.

O princípio do paradigma de Dunning é que a internacionalização da empresa só ocorrerá quando ela obtiver os três grupos de vantagens, como esquematizado na Figura 3.

Assim, segundo a teoria eclética, para a internacionalização é necessário que as empresas tenham vantagens de propriedade significativas nos mercados de origem, pois sem elas as falhas de mercado e a existência de custos de transação não justificariam a internacionalização da produção. Sem ativos específicos a proteger, não haveria necessidade de internalizar mercados e de integrar a produção para frente.

Dunning $(1988 ; 2000 ; 2002)$ ainda classificou o investimento direto estrangeiro em quatro tipos, definidos pelas motivações e direcionamento da realização da produção no exterior: a. busca por mercado (market seeking), realizada com o intuito de atender a demanda de um ou mais mercados em particular; b. busca por recursos (resource seeking), que ocorre orientada pelo acesso a recursos, que podem ser naturais, minerais, agrícolas, mão-de-obra, 
etc.; c. busca por eficiência (efficiency seeking), advém na busca por uma divisão de trabalho mais eficiente, ou maior especialização; d. busca por recursos estratégicos (strategic asset seeking), que objetiva proteger ou aumentar uma vantagem de propriedade da empresa e/ ou reduzir aquelas de suas competidoras.

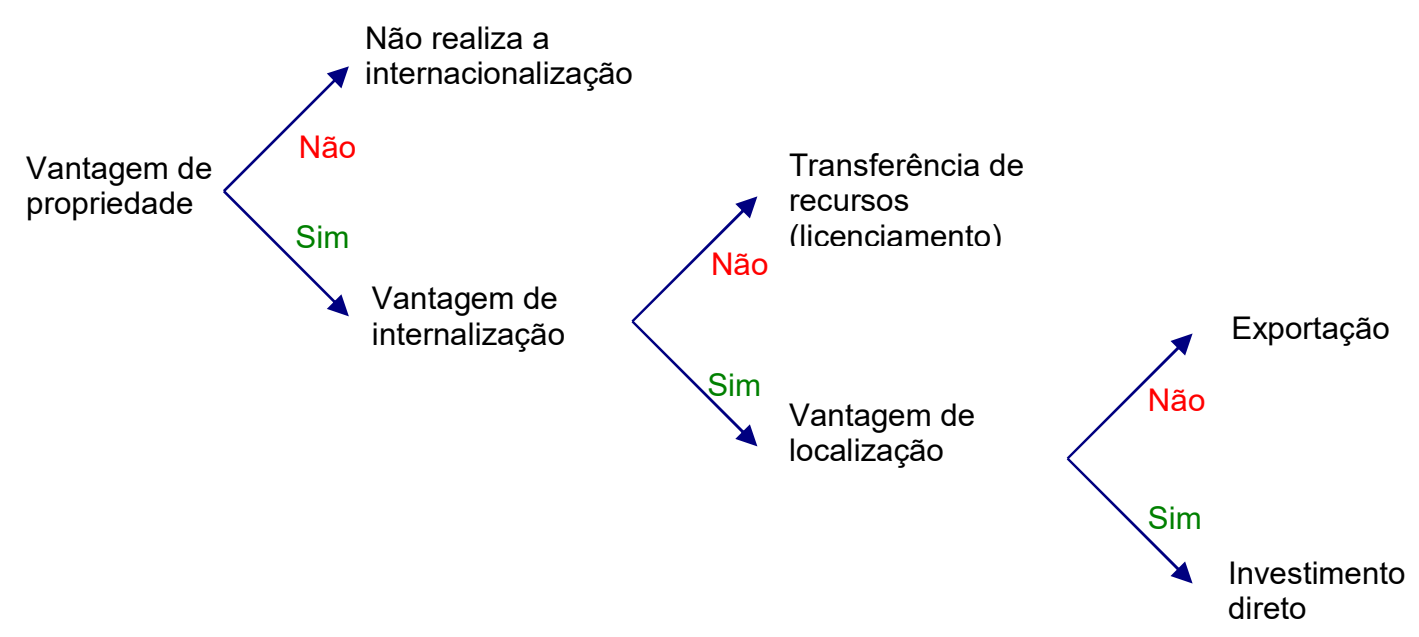

Figura 3 - Árvore de decisão para a entrada no mercado externo segundo a teoria eclética de Dunnig

Fonte: Welge, \& Holtbrügge (2003, p.73), elaborado a partir de Dunning (1981)

Algumas críticas ao paradigma eclético de Dunning são encontradas na literatura. Macharzina e Engelhard (1991) afirmam que, devido à ampla abrangência, a teoria acaba se relativizando. Já, para Perlitz (2000), a ligação dos fatores individuais, que necessitam de diferentes níveis de explicações, acaba sendo trabalhada de maneira insuficiente, não encontrando a dependência desejada dos fatores. Stehn (1992) critica o fato de que o investimento recíproco em dois ou mais países não pode ser explicado pela teoria eclética, uma vez que, de acordo com essa teoria, as vantagens de localização são em relação a outros países, e assim, o investimento direto só poderia ocorrer em um sentido. Para Hermais e Hilal (2004), o caráter estático da sua concepção não deixa espaço para as estratégias das empresas.

Dunning (2000) levanta a necessidade de uma revisão do paradigma eclético devido aos seguintes acontecimentos no final do século XX: (i) uma nova etapa do capitalismo; (ii) aprofundamento das atividades internacionais, inclusive das redes eletrônicas; (iii) maior liberdade transfronteiriça e flutuação de moedas; e (iv) novos players no cenário mundial.

Com isso, as principais revisões nos subparadigmas do tripé OLI reconhecem: 
a. O subparadigma da propriedade - há uma mudança na importância das vantagens específicas uma vez que os mercados estão mais abertos e as atividades de criação de valores são mais intensivas em conhecimento.

b. O subparadigma locacional - há a necessidade de uma abordagem mais dinâmica para as vantagens competitivas nas nações e regiões.

c. O subparadigma da internalização - há a necessidade de se levar em conta falhas de mercados, associadas à racionalidade limitada, produtos públicos fornecidos em conjunto e ativos intangíveis.

\subsubsection{Modelo Comportamentalista}

Os modelos comportamentalistas entendem que existem outros fatores, além do econômico, que moldam as decisões das firmas em relação à internacionalização. Esses fatores são de natureza diversa, estando relacionados com o ambiente externo da firma, as características da organização e as atitudes psicológicas dos seus administradores (Welge \& Holtbrügge, 2003). Orientados pela busca de redução de riscos nas decisões, a expansão internacional advém dede atitudes, percepções e comportamentos daqueles que decidem (Dib \& Carneiro, 2006).

A escola de Uppsala é a linha mais importante dentre os modelos comportamentalistas (Kutschker \& Schmid, 2005). Reconhecido como Escola Nórdica de Negócios Internacionais, este modelo foi desenvolvido pelos professores da Universidade de Uppsala, Johanson e Wiedersheim-Paul (1975) e Johanson e Vahlne (1977; 1990).

A ideia-chave desses modelos é que o processo de internacionalização ocorre gradualmente, uma vez que existem diferenças culturais e distância psicológica entre o exportador, por um lado, e o mercado a ser conquistado, por outro. Essas diferenças ou distâncias geram, sobre os resultados das transações, incertezas que só podem ser diminuídas pelo conhecimento da outra cultura (Welge \& Holtbrügge, 2003; Cyert \& March, 1963; Hernais \& Hilal, 2004). O processo de conhecimento do mercado externo ocorre de maneira gradual, uma vez que a firma aprende a outra cultura pela experiência no próprio mercado (Penrose, 1956; 2006; Aharoni, 1966; Johanson \& Vahlne, 1990; 2003; Weisfelder, 2001). Conforme há um maior envolvimento da empresa no mercado externo, a firma vai aprendendo as características da outra cultura. Consequentemente, diminuem as incertezas 
iniciais e, dessa maneira, pode ser aumentado o comprometimento de recursos nesse mercado (Johanson \& Wiedersheim-Paul, 1975; Johanson \& Vahlne, 1977).

Assim, o modelo de Uppsala, ou modelo dinâmico de aprendizagem, considera que o processo de internacionalização da empresa ocorre através de uma estratégia de natureza incremental e sequencial (Buckley, Casson \& Gulamhussen, 2002), na qual a empresa passa da expansão para mercados mais próximos fisicamente aumentando seu comprometimento com outros mercados internacionais de forma gradual, por etapas ou por meio de uma série de estágios evolutivos, formando relacionamentos cujo retorno se dará na forma de conhecimento do mercado e implicará um empenho maior de recursos a cada etapa vencida. Inicialmente, observa-se um envolvimento leve, para se adquirir conhecimento sobre o novo mercado. A partir do aumento desse conhecimento, bem como da melhoria dos canais de informações, o envolvimento se aprofunda, podendo a empresa chegar a um alto nível de envolvimento, através do estabelecimento de subsidiárias no país hospedeiro. O ponto central do modelo de Uppsala é a distância psíquica definida por Johanson e Vahlne (1977, p. 24) como "a soma de fatores que interferem no fluxo de informações entre mercados, como a diferença entre línguas, educação, práticas de negócios, cultura, desenvolvimento industrial entre outros". Ou seja, o grau de incerteza será maior, quanto mais diferente forem os países nos seus níveis de desenvolvimento, desenvolvimento industrial educação, sistema político, idioma, cultura e prática de negócios, entre outros.

É importante ressaltar que a distância psíquica abordada pelo modelo atribui relevância aos aspectos culturais e de fluxos comerciais entre os países envolvidos, tornando, em certos casos, um país mais próximo de outro apesar da distância física (Iglesias \& Veiga, 2002).

Posteriormente, Johanson e Vahlne $(1977,1990)$ refinaram o modelo, caracterizando seu aspecto incremental. Assim, as empresas definem seu processo de internacionalização a partir de variáveis como conhecimento do mercado e comprometimento de recursos. $\mathrm{O}$ conhecimento de mercado diz respeito à identificação de oportunidades e ameaças que são oriundas, a princípio, da decisão inicial de internacionalização, bem como a aquisição de informações sobre o ambiente político, econômico, cultural e social do país de destino, e depois proveniente do início das atividades (Alem \& Cavalcanti, 2005). Esse processo avança à medida que a firma se envolve com atividades comerciais e toma decisões de comprometimento de recursos, sendo a aprendizagem organizacional e a aquisição de conhecimento e experiência sobre os mercados estrangeiros determinantes tanto da velocidade de expansão das empresas no exterior, quanto da definição das regiões em que ocorrerá e de 
em quais modos operacionais será realizado (Petersen, Petersen \& Sharma, 2003). Os escritórios comerciais, as subsidiárias comerciais e fabris indicam uma sequência de maior comprometimento de recursos, como resultado do maior conhecimento (Iglesias \& Veiga, 2002).
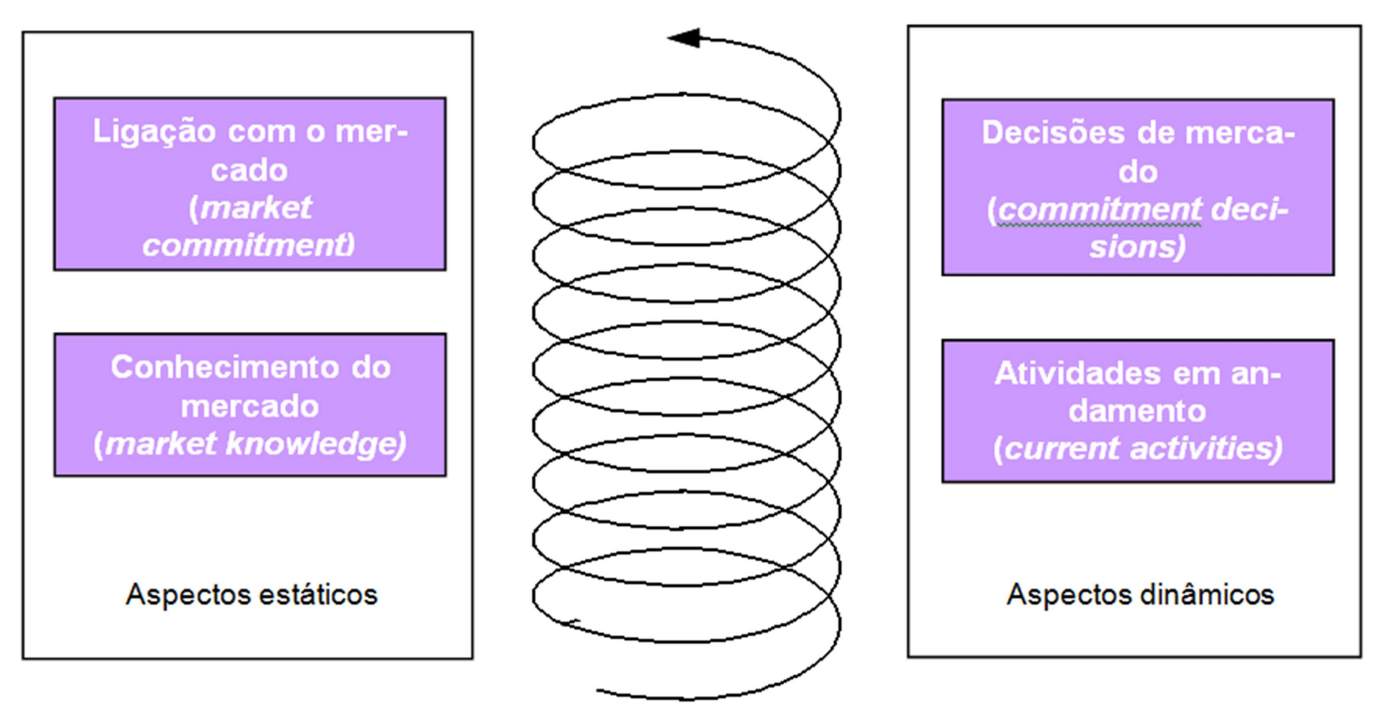

Figura 4 - Processo de Internacionalização segundo Johanson/Vahlne

Fonte: Johanson e Vahlne (1990, p. 12)

Nordström e Vahlne (1992) trouxeram para o modelo as características como o tamanho do mercado e outros determinantes econômicos importantes no processo de expansão internacional das empresas. Além disso, atentaram que o modelo não deveria ser aplicado a empresas que atuam em mercados altamente internacionalizados, pois as forças competitivas superariam a distância psíquica como fator determinante na internacionalização. Este argumento vai de acordo com Johanson e Mattsson (1988), que alegam que esse modelo é menos eficiente para mercados e empresas altamente internacionalizados.

Uma das principais críticas à escola de Uppsala é o fato de ser muito determinista, não reconhecendo que a firma pode se manter em um determinando estágio e não evoluir, assim como pode fazer uma escolha estratégica diferente quanto aos modos de entrada e expansão no mercado internacional (Fleury \& Fleury, 2007).

\subsubsection{As Novas Teorias Da Internacionalização}

Nos últimos anos, pesquisadores vêm dedicando certo esforço para buscar a compreensão das estratégias e comportamentos das novas multinacionais. Dentre tais estudos 
merecem destaque os trabalhos de Dunning e Narula (1996), Matthews (2006a, 2006b), Ramamurti e Singh (2009), e a teoria Born Global.

Dunning e Narula (1996) sugerem, por meio da teoria The Investment Development Path (IDP), que os países passam por cinco estágios de desenvolvimento, que, baseados na extensão e padrões das vantagens específicas de propriedade das empresas, das vantagens locacionais dos países e da presença de vantagens de transações relativas aos benefícios comerciais das transações entre firmas, indicam a propensão de serem investidores diretos ou receptores de investimento direto (Marinho 2013). Ou seja, o modelo sugere uma relação direta entre o nível de desenvolvimento do país e a sua posição internacional de investimento.

Os países que se encontram no primeiro estágio apresentam vantagens de localização que são consideradas insuficientes para atrair IDE, tratando-se de países com sistemas econômicos ou políticas públicas inapropriadas, uma infraestrutura inadequada de transporte e uma mão de obra desqualificada e pouco motivada. Assim, as empresas estrangeiras atuam através de exportações e importações, ou acordos de cooperação com empresas locais que não envolvam nenhum tipo de responsabilidade societária.

No segundo estágio, o país cria alguma vantagem específica de localização, o que leva a um aumento do IDE, eventualmente estimulado por um crescimento do mercado interno tanto em tamanho quanto em poder de compra. As empresas nacionais desenvolvem algumas vantagens de propriedade, o que possibilita que as mesmas iniciem um processo de internacionalização de suas atividades buscando novos mercados em regiões ou países que se situam em estágio de desenvolvimento menor, ou ainda invistam em países situados em estágios de desenvolvimento maior com a finalidade de aumentar seus ativos estratégicos e suas vantagens de propriedade.

O terceiro estágio é marcado por redução gradual da taxa de crescimento dos fluxos de IDE e por um aumento dos seus investimentos diretos no resto do mundo, o que deverá permitir o aumento de sua posição internacional de investimento. As empresas nacionais modificam suas vantagens de propriedade e aumentam suas competências e habilidades de gerenciar e coordenar ativos localizados em diferentes áreas geográficas.

Quando o estoque de IDE no exterior iguala ou supera o de empresas estrangeiras no mercado nacional, o país entra no quarto estágio. A taxa de crescimento do IDE no exterior continua aumentando mais rapidamente que a do IDE interno, ou seja, as empresas domésticas passam a competir efetivamente em outros mercados e regiões.

O quinto estágio é caracterizado por um equilíbrio nos fluxos de saída e entrada de IDE. Neste estágio, o IDE das suas empresas no exterior depende das estratégias das mesmas, 
e não das diferenças que possam existir entre os países. Portanto, suas multinacionais atuam independentemente das vantagens de localização do seu país de origem.

Já John Matthews (2006a, 2006b) propõe o conceito de Challenger Multinational Enterprise para designar as multinacionais, caracterizadas por uma rápida internacionalização, alta capacidade de inovações estratégicas e organizacionais e por sua articulação com a economia global através de complexos vínculos entre firmas (Marinho 2013).

Ao contrário, do Paradigma OLI, em que as empresas multinacionais exploram no exterior os recursos desenvolvidos em seus países de origem, as Challenger Multinational se internacionalizam com a finalidade de conseguir os recursos que precisam, atuando no mercado global de forma integrada, o que favorece a criação de cadeias de valor cujas funções estão distribuídas mundialmente. John Matthews (2006a; 2006b) denomina esse processo de internacionalização como "a segunda economia global" e propõe o Paradigma LLL (Linkagem, Leveraging, Learning) como mais adequado para a compreensão do mesmo:

i. Linkagem (ligação): aquisição de recursos ocorre através de colaboração com outras firmas, o que leva a redução dos riscos inerentes às operações no mercado externo. As novas multinacionais buscam vantagens que podem ser adquiridas externamente, sobre os recursos que podem ser acessados fora delas.

ii. Leveraging (alavancagem): o foco é sobre as formas como as ligações podem ser estabelecidas para se ter acesso aos recursos, possibilidades de imitação, transferências ou substituição, ou seja, o objeto de análise é verificar de que forma esses obstáculos de entrada podem ser superados.

iii. Learning (aprendizagem): a repetição de ligações e alavancagens resulta na aprendizagem da empresa em realizar tais operações de forma mais eficiente (aprendizagem organizacional), incrementando sua produtividade.

Outra linha teórica surge com Ramamurti e Singh (2009) que apresentam um grupo de estratégias genéricas de internacionalização a partir da análise do contexto dos países emergentes (vantagens específicas do país de origem) e das vantagens específicas das firmas neles localizadas, que apresentam adequação dos produtos a mercados emergentes, produção e excelência operacional, acesso privilegiado a recursos e mercados; vantagem da adversidade e ativos tangíveis tradicionais (Marinho 2013). Os autores propõem cinco estratégias genéricas: 
i. Integração vertical de recursos naturais - adotada por empresas geralmente originárias de um país rico em recursos naturais ou que possui um grande mercado doméstico para explorar.

ii. Otimizador local - as empresas obtêm vantagens ao aperfeiçoar seus produtos e processos às condições especiais do mercado.

iii. Parceiro de baixo custo - estratégia obtida pela vantagem de mão de obra barata visando servir às necessidades de empresas sediadas em países ricos.

iv. Consolidador global - refere-se a empresas que, como o nome sugere, consolidam indústria, atendendo os diversos níveis da cadeia produtiva.

v. First-mover global - caracteriza-se pela estratégia de criação de um negócio global em uma nova indústria ou segmento. As empresas identificam uma oportunidade de implantação de um negócio inovador em uma indústria existente, ou, ainda, de uma inovação tecnológica, sendo, assim, inovadora tanto em termos do que faz quanto em como o faz em relação a seus competidores locais e estrangeiros.

O termo Born Global ${ }^{1}$ deriva de um estudo realizado no início da década de 1990 pela firma de consultoria Mckinsey (Marinho, 2013), que identificou um número significativo de empresas de pequeno e médio porte que não seguiram um processo lento e gradual de desenvolvimento internacional, mas que já nasceram globais. A propriedade de ativos fora no seu país de origem, não é uma condição essencial desses empreendimentos internacionais, sendo sua principal preocupação com o valor agregado no produto e suas competências para mantê-lo e adaptá-lo. (Oviatt \& McDougall, 1994 apud Marinho, 2013). O principal modo de entrada das Borns Globals nos mercados internacionais é através das exportações. Pode-se dizer que, de modo geral, as novas teorias de internacionalização se limitam a alguns aspectos ou casos específicos, não tendo ainda demonstrado serem capazes de compreender esse fenômeno como um todo.

\footnotetext{
A literatura de negócios internacionais apresenta diferentes denominações para esse fenômeno: Born Global (Rennie, 1993; Dib, 2008); Global start-ups (Oviatt \& McDougall, 1994); Early internationalizing firms (Rialp \& Rialp, 2007); entre outros. Nesta tese será adotado o termo Born Global por ser o mais utilizado e difundido.
} 
2.2.4 Escolha da Forma de Internacionalização

$\mathrm{Na}$ construção de suas redes de produção internacionais, as transnacionais têm que decidir não apenas sobre a localização, mas também sobre o modo de controle e coordenação das operações internacionais (Unctad, 2011). Assim, a escolha do método de entrada em um mercado externo é um passo importante após a empresa decidir se internacionalizar (Nickels \& Wood, 1997).

Ao optar pela expansão para o mercado externo, a empresa tem três opções possíveis: a atuação isolada e independente, a criação de subsidiárias no estrangeiro ou a colaboração com outras empresas. Na escolha da estratégia de internacionalização, a empresa deve levar em conta as características culturais, econômicas e geopolíticas da nação de origem e do país de destino. Neste sentido, Stoner e Freeman (1995) apontam que as empresas devem se preocupar com os padrões de desenvolvimento econômico, infraestrutura, crescimento e saturação do mercado, níveis de inflação, taxas de câmbio e balança de pagamentos, dentre vários outros fatores econômicos, bem como estar atenta aos tipos de controle de exportações, importações e investimentos estrangeiros. A empresa deve também considerar os fatores políticos que afetam o ambiente de negócios no país hospedeiro e estão relacionados à estabilidade política, à eficácia da burocracia governamental, ao sistema legal, à política externa e às atitudes em relação aos negócios e ao investimento externo (Almeida \& Lara, 2010). Os fatores tecnológicos também desempenham um papel de destaque no contexto dos negócios internacionais, especialmente porque os avanços, nesta área, tornam-se cada vez mais rápidos e requerem adaptação para que possam ser transferidos. Neste contexto, a própria escolha das estratégias de internacionalização, ou modos de entrada em mercados internacionais de uma empresa, pode depender das características tecnológicas incorporadas em sua atividade.

A escolha da forma de internacionalização pode ser vista como uma combinação de decisões interdependentes sobre a forma de trabalho, de propriedade e de "colonização" do mercado (Welge \& Holtbrügge, 2003). A escolha da forma de trabalhar o mercado envolve as decisões sobre quais as atividades serão realizadas no mercado local e quais nos países para os quais elas estão se internacionalizando. Enquanto com a exportação apenas o último nível do processo de comercialização ocorre no país de destino, na abertura de uma filial no exterior, pode-se observar o processo de produção e distribuição realizados nesse país. As decisões sobre a forma de propriedade se referem ao tipo de transferência de recursos, ou seja, se a empresa transferirá conhecimentos à outra através de joint ventures, fará cooperação ou 
seguirá sozinha. Segundo Welge e Holtbrügge (2003), o último grupo de decisões é a forma de "colonização" que envolve a possibilidade de "ligação" dos recursos através de combinação de atividades com outras empresas ou a compra de todos os recursos.

Para os autores Boone e Kurtz (1998), os níveis de envolvimento no mercado internacional são determinados de acordo com critérios de risco e controle. O método de entrada adequado nos mercados externos dependerá de fatores específicos da empresa e da indústria a qual pertence. Exemplos desses fatores são os objetivos da empresa em relação ao volume de negócios internacionais desejados, cobertura geográfica, concorrência externa, tamanho da empresa em venda e ativos, linha de produtos da empresa e sua natureza (consumidor industrial ou consumidores finais, alto ou baixo preço, conteúdo tecnológico) (Terpstra \& Sarathy, 1997).

A exportação é a primeira alternativa de internacionalização para empresas incipientes em relação a mercados externos. Muito utilizada, essa alternativa requer um grau reduzido de risco e comprometimento por parte da empresa. (Jeannet \& Hennessey, 1992; Nickels \& Wood, 1997; Terpstra \& Sarathy, 1997).

De acordo com Rocha (1988, p. 125), "tornar-se exportador significa aceitar determinados riscos e consequências, positivas e negativas, para a empresa". A tomada de decisão rumo à exportação traz consigo, de forma tácita, a aceitação de riscos e comprometimento inerentes a essa atividade.

De uma maneira mais rigorosa, segundo Jeannet e Hennessey (1992), Kotler (1998) e Terpstra e Sarathy (1997), as exportações podem ser divididas em dois tipos de operações: as exportações diretas e indiretas. As exportações diretas são aquelas realizadas através de um intermediário localizado fora do país de origem, como, por exemplo, atacadistas, representante comissionado, distribuidores, agente do fabricante, filial de vendas, além das exportações realizadas diretamente ao consumidor final. A vantagem é que possibilita ao exportador um maior controle sobre os canais de distribuição utilizados e, portanto, sobre o mercado para o qual está exportando (Kutschker \& Schmid, 2005).

As exportações indiretas são realizadas por intermediário localizado no país do fabricante. A vantagem desse tipo de exportação é que o agente é quem tem que conhecer as normas e trâmites do comércio internacional, logo, o fabricante não necessita uma estrutura própria (Kutschker \& Schmid, 2005).

Segundo Kotler (2000), a maneira básica de envolvimento no mercado internacional é a propriedade direta de instalações de fabricação ou montagem no exterior, através do investimento direto estrangeiro (IDE). A empresa estrangeira pode comprar uma empresa 
local, ou tornar-se acionista, ou construir suas próprias instalações (Welge \& Holtbrügge, 2003). Se o mercado em questão parecer suficientemente grande, as instalações de produção, neste país, oferecem várias vantagens. Primeiramente, a empresa garante economia de custos por meio de mão-de-obra e matérias-primas mais baratas, incentivos do governo para investimentos estrangeiros e economia de frete. Em segundo lugar, fortalece sua imagem no país que a hospeda porque cria empregos. Em terceiro lugar, desenvolve um relacionamento mais profundo com o governo, os clientes, os fornecedores locais e os distribuidores. Em quarto lugar, mantém total controle sobre os seus investimentos. Entretanto, eventuais riscos e desvantagens devem ser avaliados e ponderados uma vez que as exigências de capital e recursos, bem como o risco inerente, serão mais altos (Boddewyn, 1985).

Entre as formas de exportação e IDE, há formas intermediárias, que permitem as empresas transnacionais um "meio-termo" na sua governança, exteriorizando atividades, mantendo um nível de controle, ou seja, permitem um melhor trade-off entre as vantagens e os custos da externalização (Hennart, 2009). A escolha, portanto, não está apenas entre o controle através de participação (IDE) ou livre mercado (exportação), mas entre uma variedade de modos em que o controle é exercido em várias configurações e em vários graus, através de contratos e poder de negociação. Os modos intermediários nas operações transfronteiriças surgem quando a empresa exterioriza parte de suas operações para um parceiro com base no país de acolhimento, no qual não tem participação acionária, mantendo um nível de controle sobre a operação, contratualmente (Unctad, 2011).

$\mathrm{Na}$ análise do modo de entrada, os custos de internalização das atividades devem ser avaliados em relação às vantagens óbvias de manter o controle completo sobre a cadeia de valor. As transnacionais buscam maximizar a captura de valor, contudo, a externalização claramente implica desistir de parte dos lucros gerados ao longo da cadeia. No entanto, a internalização evita os custos de transação associados à apropriação de terceiros e aos acordos contratuais que tendem a se tornar mais complexos quanto maiores os riscos percebidos associados com a perda de controle sobre partes da cadeia de valor, ativos e valiosa propriedade intelectual (Unctad, 2011). Além disso, a internalização também elimina os custos de gerenciamento de relações com parceiros, incluindo os fluxos de conhecimentos, produtos e serviços, além dos fluxos de comunicação, informação, monitoramento e controlo do cumprimento das obrigações contratuais (Unctad, 2011).

Por outro lado, a externalização tem um número de vantagens intrínsecas, como a transferência de certos custos e riscos a terceiros, bem como o acesso rápido aos bens e recursos de terceiros através da parceria. Tais recursos podem ser plantas produtivas e 
equipamentos, capacidade tecnológica e know-how, ou mesmo redes e relacionamentos nos países de acolhimento. Além disso, a externalização permite a empresa estabelecer uma divisão interna das tarefas mais eficaz, libertando recursos escassos para ser usado em outros segmentos de sua cadeia de valor, focando no seu core business. Quanto mais fácil a transferência de conhecimento e propriedade intelectuais necessários à realização da atividade, mais viável será a externalização (Unctad, 2011).

Logo, a configuração de propriedade e controle na atuação no país de acolhimento é o resultado de um conjunto de opções estratégicas pela empresa transnacional. As transnacionais são geralmente preparadas para terceirizar qualquer atividade que não sejam fundamentais para a vantagem competitiva em seu mercado ou indústria e que possam ser realizadas a um menor custo ou de forma mais eficaz por parte de terceiros, desde que os riscos associados à externalização sejam limitados ou possam ser contidos (Unctad, 2011).

A Figura 5 apresenta as formas intermediárias de internacionalização a partir de uma adaptação da nomenclatura utilizada pela Unctad (2011).

\begin{tabular}{|c|l|}
\hline Formas de Contratos & \multicolumn{1}{c|}{ Definições } \\
\hline $\begin{array}{c}\text { Contratos de produção } \\
\text { Terceirização de serviços }\end{array}$ & $\begin{array}{l}\text { Relações contratuais através das quais uma empresa internacional contrata a } \\
\text { produção ou determinado serviço da sua cadeia de valor (o que se estende até } \\
\text { mesmo para os aspectos de desenvolvimento de produto) de uma empresa do país } \\
\text { de acolhimento. Serviços de terceirização normalmente envolvem a } \\
\text { externalização de processos de suporte, incluindo funções de conhecimento de TI, } \\
\text { e de negócios. }\end{array}$ \\
\hline \multirow{3}{*}{ Agricultura por contrato } & $\begin{array}{l}\text { Relação contratual entre um comprador internacional e associações de } \\
\text { agricultores (incluindo o formato através de intermediários) do país anfitrião, que } \\
\text { estabelece condições para o cultivo e comercialização de produtos agrícolas. }\end{array}$ \\
\hline Licenciamento & $\begin{array}{l}\text { Relação contratual em que uma empresa (licenciador) oferece para uma empresa } \\
\text { de um país de acolhimento (licenciado) o direito de usar uma propriedade } \\
\text { intelectual (por exemplo, direitos autorais, marcas, patentes, direitos de design } \\
\text { industrial, segredos comerciais) em troca de pagamento (royalties). } \\
\text { Licenciamento pode assumir várias formas, incluindo o licenciamento da marca, } \\
\text { licenciamento de produtos e licenciamento de processo. O licenciamento refere- } \\
\text { se a uma empresa adquirir uma licença de outra empresa. As licenças são } \\
\text { concedidas por períodos de tempo, territórios e produtos determinados, sendo } \\
\text { considerados os investimentos necessários para a entrada no mercado, os quais, } \\
\text { normalmente, são bem inferiores aos requeridos para o desenvolvimento de um } \\
\text { produto novo, e o tipo de empresa ou indústria licenciada (Kutschker \& Schmid, } \\
\text { 2005, p. 841). }\end{array}$ \\
\hline Contratos de gestão & $\begin{array}{l}\text { Relação contratual em que o controle operacional de um ativo em um país de } \\
\text { acolhimento é realizado por uma empresa internacional, o contratante, que } \\
\text { administra o ativo em troca de uma taxa. }\end{array}$ \\
\hline
\end{tabular}

(Continua)

Figura 5 - Formas de internacionalização 


\begin{tabular}{|c|c|}
\hline Formas de Contratos & Definições \\
\hline Franquias & $\begin{array}{l}\text { Relação contratual em que uma empresa internacional (franqueador) permite que } \\
\text { uma empresa de um país de acolhimento (franqueado) realize um negócio } \\
\text { utilizando-se do modelo desenvolvido pelo franqueador em troca de uma taxa ou } \\
\text { de um mark-up sobre os bens ou serviços fornecidos pelo franqueado. De acordo } \\
\text { com Minervini (1991, p. 97), em geral, traduz-se num acordo através do qual uma } \\
\text { empresa (o "franquiado") obtém de outra (o "franqueador") o direito de explorar } \\
\text { em exclusivo e sob certas condições um produto, uma marca ou tecnologia dentro } \\
\text { de uma determinada área. Na prática esse direito é um "pacote" que inclui não só } \\
\text { marcas e know-how tecnológico, mas também assistência na gestão do negócio, } \\
\text { nomeadamente, na área financeira e comercial (Welge \& Holtbrügge, 2003, p. } \\
\text { 101). }\end{array}$ \\
\hline Concessões & $\begin{array}{l}\text { Relação contratual em que o controle operacional de um ativo no país de } \\
\text { acolhimento é realizado por uma empresa internacional, a concessionária. A } \\
\text { empresa gerencia os ativos em contra partida ao retorno (ou parte do retorno) } \\
\text { gerado pelos mesmos. Concessões são normalmente acordos complexos, como } \\
\text { arranjos de build own transfer, o que pode incluir elementos de investimento por } \\
\text { parte da empresa transnacional ou propriedade do ativo por um período. } \\
\text { Legalmente eles podem ser estruturados de várias maneiras, inclusive como } \\
\text { parcerias público-privadas (PPPs). }\end{array}$ \\
\hline Joint ventures contratuais & $\begin{array}{l}\text { Relação contratual entre duas ou mais empresas para perseguir um objetivo } \\
\text { conjunto de negócio. Os contratos estabelecem os termos, obrigações e } \\
\text { responsabilidades das partes, mas não implicam na criação de uma nova entidade } \\
\text { jurídica. "Crescer a partir de uma associação em que cada uma das partes coloque } \\
\text { a melhor de suas capacidades, tecnologia e know-how é o ideal das empresas que } \\
\text { formam joint ventures" (IFC, 1998: 12). De acordo com a OCDE, uma joint } \\
\text { venture consiste na participação de várias empresas no capital de uma unidade } \\
\text { econômica juridicamente independente dando assim origem à partilha do } \\
\text { respectivo patrimônio, lucros e risco de negócio. }\end{array}$ \\
\hline Alianças estratégicas & $\begin{array}{l}\text { Relação contratual entre dois ou mais parceiros estratégicos. Ao contrário de uma } \\
\text { joint venture, a aliança estratégica consiste na associação de várias empresas } \\
\text { dando origem à criação de uma nova organização (KUTSCKER; SCHMID, 2005: } \\
\text { 869). Os parceiros decidem exatamente em que área cada um irá cooperar. Os } \\
\text { parceiros podem fornecer a aliança com produtos, canais de distribuição, } \\
\text { capacidade de produção, equipamentos de capital, conhecimento, experiência, ou } \\
\text { de propriedade intelectual. Alianças estratégicas envolvem transferência de } \\
\text { propriedade intelectual, especialização, despesas compartilhadas e risco. Os } \\
\text { principais motivos que levam as empresas a fecharem alianças estratégicas são: } \\
\text { atingir economias de escala e de escopo, bem como dividir os riscos na entrada de } \\
\text { novos mercados, obtenção de uma maior flexibilidade, e gestão de novos } \\
\text { conhecimentos (GLAISTER; BUCKLEY, 1996, p. 303-308). }\end{array}$ \\
\hline
\end{tabular}

(Conclusão)

Figura 5 - Formas de internacionalização

Fonte: Unctad, Wir (2011, p. 128)

Para Welge e Holtbrügge (2003), as vantagens de um licenciamento são geradas principalmente por se tratar de uma forma segura de entrada no mercado internacional, que não exige grandes custos para o licenciador. Além disso, a proximidade do novo mercado permite a empresa utilizar o contato do licenciado com os consumidores para colher informações do mercado, adaptando o produto ou serviço a esse mercado mais facilmente. Há, entretanto, desvantagens nesta forma de internacionalização, como, por exemplo, a 
dependência do licenciador de que o licenciado gere receita para poder pagar os royalties devidos, os quais, normalmente, são acordados sobre o volume de vendas gerado pelo produto em questão. Outra desvantagem é a não garantia da qualidade do produto fabricado pelo licenciado, o que pode vir a danificar a imagem do licenciador (Walldorf, 1987).

Segundo Minervini (1991), o licenciamento é a forma mais rápida de entrar no mercado internacional e é particularmente adaptável para pequenas e médias empresas que não possuem grandes recursos financeiros, organizacionais e de pessoal, mas que apresentam conhecimentos altamente especializados para oferecer, obtendo vantagens. Todavia, há de se considerar a possibilidade de praticamente se estar criando um concorrente no mercado internacional, daí a importância da seleção e avaliação do parceiro escolhido. Por outro lado, ao não se transferir tecnologia, outros poderão fazê-lo.

Relativamente à exportação, o licenciamento reduz a necessidade de investimentos de prospecção do licenciador, ao mesmo tempo em que possibilita o acesso a mercados que poderiam ser inacessíveis. Já, para o concessionário, a vantagem encontra-se no acesso a produtos, tecnologias, conhecimentos ou marcas já testadas em outros mercados (Contractor, 1981).

As joint ventures, por sua vez, podem trazer múltiplas vantagens às empresas envolvidas no acordo (Roos, 1989 apud Welge \& Holtbrügge, 2003), como as reduções de custos geradas por economias de escala, menores necessidades de financiamento, acesso a novas tecnologias, novos mercados, novas formas de gestão, entre outros. Para empresas de países em desenvolvimento, o acesso à tecnologia é a mais importante contribuição que um sócio estrangeiro pode fornecer, além da reputação internacional da empresa multinacional e o acesso aos mercados de exportação. Contudo, a literatura apresenta também diversas dificuldades encontradas por empresas que iniciam uma joint venture. Walldorf (1987) destaca os problemas encontrados na definição dos termos para o acordo que satisfaça ambas as partes, ainda mais quando a joint venture é formada por empresas com antecedentes culturais diferentes. Problemas como cuidados com o direito de concorrência, convergência estratégica de ambas as partes, altos custos de coordenação e integração, bem como a dificuldade para medir os resultados são detalhadamente discutidos por Kutschker e Schmid (2005).

Em relação às alianças estratégicas, Kutscker e Schmid (2005) argumentam algumas desvantagens, sendo as principais: necessidade alta de concordância entre as empresas parceiras, perda de conhecimento para o concorrente, dificuldade de equilíbrio entre a 
cooperação e a concorrência com as demais empresas, escolha de parceiros errados, confiança entre os parceiros e dificuldade de medição de resultados obtidos.

\subsection{Fundamentação Econômica}

\subsubsection{Teoria dos Custos de Transação}

Segundo os teóricos institucionalistas, as causas para a internacionalização de empresas podem ser buscadas no conceito de origem da firma, apresentado por Coase em seu artigo The nature of the Firm (1937), no qual ele apresenta que o benefício de incorporar uma transação que acontece no mercado para os domínios da empresa é gerado devido aos custos de transação. Considerando que no mercado real os custos de transação não são nulos, o surgimento da empresa será justificado quando o processo de coordenação da atividade internamente for mais produtivo do que se deixar a atividade no mercado. O processo de internacionalização das empresas pode ser compreendido neste contexto.

Para North (1991), o ambiente econômico é formado por uma matriz institucional, que é o resultado observado pelo conjunto dos efeitos das instituições formais e informais em determinado mercado. As instituições influenciam o modo como às organizações realizam essas trocas.

Quando os custos da organização com atividades através do mercado superam os custos de realizá-las internamente, surge a firma. Ou seja, decisões otimizadoras dos agentes econômicos relativas à minimização de custos de transação definem os limites da firma (Saes, 2008).

Seguindo esta linha, Williamson (1985) apresenta que a economia dos custos de transação coloca o problema da organização econômica como um problema de contratação: contratos implícitos ou explícitos e aparelhos de apoio associados a cada um deles. $\mathrm{O}$ autor chama a atenção para os custos de transação ex-ante e ex-post. Ex-ante são os custos de elaboração, negociação e salvaguarda de um acordo. Os custos ex-post estão relacionados à má adaptação do contrato em relação aos envolvidos, aos custos de negociação para corrigir os desalinhamentos ex-post, aos custos de funcionamento da estrutura de governança sob a qual as disputas são submetidas, e aos custos de ligação de efetuar compromissos seguros. Tais custos são difíceis de quantificar. 
A ECT sustenta que a economia nos custos de transação é a principal responsável pela escolha de uma forma de organização em detrimento de outra. Williamson (1996) afirma que essa hipótese pode ser levantada para qualquer questão que envolva direta ou indiretamente um problema de contratação (Williamson, 1996).

Williamson define que as transações se diferenciam por três características básicas: a especificidade dos ativos (não específico, misto ou muito especifico), a incerteza (intrínseca à transação, uma vez que as sucessivas adaptações ocorrem devido à impossibilidade de se enumerar todas as futuras contingências ou adaptações que surgirão com o passar do tempo) e a frequência (ocasional ou recorrente). A frequência das transações define os custos fixos médios relacionados à coleta de informações e à elaboração de contratos entre as partes, bem como a facilidade de se impor perdas aos contratantes para evitar comportamento oportunista. Logo, quanto maior a frequência, menor o custo e o risco de comportamento oportunista. As incertezas estão associadas às transações e às preferências dos consumidores e à complexidade do próprio ambiente econômico, que impossibilita uma avaliação precisa, podendo acarretar maiores custos. Quanto maior a incerteza, maior a dificuldade e o risco no desenvolvimento de parcerias (Saes, 2008).

De acordo com Zylbersztajn e Neves (2000), a incerteza está associada a efeitos não previsíveis, não passíveis de terem uma função de probabilidade conhecida a eles associada. Segundo os autores, a impossibilidade de previsão de choques que alterarem as características dos resultados da transação, não permite que os agentes participantes definam cláusulas contratuais que relacionem a distribuição dos resultados aos impactos externos, já que estes não são conhecidos ex-ante.

O principal fator que explica a economia de custos de transação na integração vertical é a especificidade (Williamson, 1985). Sem ela, a contratação no mercado entre as etapas de produção sucessivas, normalmente, tem boas propriedades de economia. À medida que aumenta a especificidade de ativos, o equilíbrio desloca a favor da organização interna.

O gerenciamento dessas transações é feito por mecanismos de controle denominado "estruturas de governança", enquadradas em três categorias: de mercado, intermediárias e hierárquicas. A definição dos mecanismos relativos a essas estruturas afeta diretamente os limites de eficiência das firmas e pode representar soluções com custos e potenciais diferenciados para a mitigação do oportunismo nas transações econômicas.

Os custos de transação devem ser relacionados aos pressupostos comportamentais do modelo, que se encontram na racionalidade limitada e no oportunismo. A assimetria de informações faz com que apesar dos indivíduos buscarem a maximização dos lucros, sua 
racionalidade seja limitada, logo, em vez de uma decisão ótima, o agente toma a melhor decisão possível, dado o seu conhecimento limitado (Saes, 2008). Já o oportunismo ocorre devido aos agentes econômicos agirem em benefício próprio com astúcia. Segundo Saes (2008), a informação incompleta ou limitada pode dar margem a ações oportunistas.

A redução de barreiras e o advento da tecnologia, possibilitando acesso rápido e até mesmo remoto a diferentes mercados, ocasionou um aumento dos fluxos de produtos e serviços entre os países. A coordenação eficiente desses produtos e serviços transacionados internacionalmente pode ser complexa e com altos custos de transações, o que direciona as empresas na criação de multinacionais (Buckley \& Casson, 2002). Desta maneira, a lógica da internacionalização está atrelada à necessidade de superação das imperfeições do mercado a partir dos fatores específicos da indústria na qual as empresas estão inseridas, uma vez que as características do setor de atuação determinam a necessidade ou não de internalização da produção (Coelho, 2014). Assim, o processo de integração vertical da produção é um determinante para o surgimento das multinacionais, que, pela ótica dos custos de transação, buscam, através das vantagens comparativas dos países, a distribuição dos seus fatores onde eles possam ser melhores otimizados (Coelho, 2014).

Com isso, pode-se dizer que no processo de internalização, ao observar as vantagens comparativas e as características institucionais das diferentes localidades, a empresa define a estratégia de expansão para o mercado, optando pela melhor forma de entrada diante das suas vantagens específicas, das características da indústria de atuação e em função das imperfeições de mercado (Rugman, 1981; Buckley \& Casson, 2002).

Williamson (1991) defende que a decisão entre contratar agentes no mercado ou internalizar o processo ou produção por meio de hierarquias é resultado das imperfeições de mercados, que geram custos de transação, que serão analisados de forma a maximizar os resultados da empresa.

Para Teece (1986a; 1986b), a decisão de internalizar a produção ou externalizá-la com um agente estrangeiro, via contratos, está atrelada não apenas aos custos de transação, mas, também, à transferência de conhecimento. 


\subsubsection{Visão Baseada em Recursos (VBR) ou Resource Based View (RBV)}

A Visão Baseada em Recursos (VBR) é uma abordagem que combina a análise interna das empresas e a análise externa do setor e do ambiente competitivo, desenvolvendo, a partir disso, a estratégia da empresa.

Penrose (1995:49) define que "a diferença essencial entre as atividades econômicas internas à firma e as que são realizadas no mercado é o fato de que as primeiras se desenvolvem no contexto de uma organização administrativa, enquanto as segundas não". A autora argumenta que "o aumento do tamanho, qualquer que seja sua definição, da unidade produtiva administrativa tem importância porque quanto maior for essa unidade, tanto menor será a medida na qual a destinação dos recursos produtivos para diferentes usos e através do tempo estará diretamente subordinada às forças de mercado, e tanto maior serão as oportunidades para um planejamento consciente das atividades econômicas" (Penrose; 1995:49).

A VBR busca identificar os recursos e capacidades de uma firma que proporcionam a organização, uma vantagem competitiva sustentável (Barney \& Hesterly, 1999). Segundo Wernerfelt (1984, p.172), recurso pode ser definido como "qualquer coisa que pode ser pensada como um ponto forte ou uma fraqueza de uma empresa".

A VBR busca explicar e prever a razão de certas empresas serem capazes de constituir posições de vantagens competitivas sustentáveis, percebendo a empresa como um conjunto de recursos e capacidades cuja principal função da gestão é maximizar o valor por intermédio da ótima utilização dos recursos e capacidades (Grant, 1996).

Barney \& Clark (2007) apresentam os pressupostos da VBR para a análise de fontes de vantagem competitiva. Os autores argumentam que esse modelo pressupõe que as empresas dentro de uma indústria (ou grupo) podem ser heterogêneas com relação aos recursos estratégicos que elas controlam. Assim, o cerne da VBR pressupõe um modelo de equilíbrio competitivo, com pelo menos uma empresa heterogênea (Demsetz, 1973; Lippman \& Rumelt, 1982; Barney, 1991; Peteraf, 1993; Peteraf \& Barney, 2003; Foss \& Stieglitz, 2010). Tais recursos não podem ser perfeitamente móveis entre as empresas e, assim, a heterogeneidade pode ser de longa duração. A VBR analisa as implicações dessas duas hipóteses para a análise de fontes de vantagem competitiva sustentável.

Barney afirma que tão importante quanto explicar a existência de vantagens competitivas entre as empresas, é a análise da sustentabilidade dessas vantagens, sendo que algumas vantagens podem ser fugazes, e outras de longa duração. Uma empresa é dita ter uma 
vantagem competitiva sustentável quando cria mais valor econômico do que a empresa marginal em sua indústria e, quando outras empresas são incapazes de duplicar os benefícios desta estratégia (Barney \& Clark; 2007).

Barney (1990) sugere que as fontes de vantagem competitiva sustentada são recursos da empresa que são valiosos, raros, imperfeitamente imitável, e explorado pela organização. Esses recursos incluem uma ampla gama de fenômenos organizacionais, sociais e individuais dentro das empresas. Ao invés de ser contraditório, o modelo da VBR sugere que as teorias de organização e comportamento organizacional podem ser uma rica fonte de descobertas e teorias sobre recursos raros, não imitáveis, e exploráveis nas empresas (Barney \& Clark; 2007). Neste contexto, os gestores são importantes, pois eles são capazes de compreender e descrever o potencial de desempenho econômico de uma organização. Sem tais análises gerenciais, a vantagem competitiva sustentada não é provável (Barney \& Clark; 2007).

Segundo Barney (2007), "uma organização tem vantagem competitiva se ela consegue criar valor econômico além do ponto de equilíbrio de um produto concorrente" (Barney, 2007: p.24). Valor econômico pode ser compreendido como a diferença entre o custo do bem ou serviço para a empresa e o ganho de benefício percebido pelo consumidor. Assim, a vantagem competitiva está na capacidade de a empresa criar valor.

Foss e Foss (2005) argumentam que os custos de transação são presente na estrutura da VBR. A unidade básica de análise na VBR é o recurso. A noção de recurso possui apelo direto e intuitivo, porque pode ser associado tanto a bens físicos, como máquinas, edifícios, peritos, e assim por diante, quanto a serviços de rendimento dos recursos (Penrose, 1959). Na verdade, os recursos são realmente coleções de "atributos", isto é, serviços, funcionalidades, etc. Em um mundo sem custos de transação, todos esses atributos poderiam ser identificados e negociados, e não haveria razão para trocar recursos discretos (Foss \& Stiglitz, 2010).

Estes fundamentos indicam que o desempenho da firma se relaciona ao desenvolvimento de recursos internos ou adquiridos no mercado de forma específica. Assim, a criação, manutenção e renovação da vantagem competitiva estão, fortemente, relacionadas aos recursos (atributos) internos da empresa (Foss, 1993). A organização deve identificar os recursos relevantes para a obtenção da vantagem competitiva sustentável, ou seja, de difícil imitação (Barney, 1991). Barney (1995) argumenta que a sustentabilidade da vantagem competitiva está relacionada ao estoque de recursos, o que possibilita as empresas resistirem às pressões dos concorrentes.

Barney (2002) elaborou uma estrutura de análise para a verificação se um recurso ou capacidade é um ponto forte ou fraco da organização através de questionamentos sobre o 
valor (se o recurso agrega valor ou reduz custos), raridade (se é utilizado por um número pequeno de concorrentes), imitabilidade (se o custo de obtenção pela concorrência é elevado) e organização (se existem normas ou procedimentos organizados para tirar o máximo de proveito desses recursos).

Para Barney (2002), a partir das respostas da análise VRIO (valor, raridade, imitabilidade e organização), é possível identificar se esse recurso contribui em termos de implicações competitivas (temporária ou sustentada), bem como de desempenho econômico (abaixo do normal, normal ou superior ao normal).

A VBR tem, em sua essência, conceituar os recursos como o embasamento principal para a estratégia da firma. Outra vertente da VBR, que se pode dizer que herdeira de Penrose, segue uma linha de análise mais focada na capacidade dinâmica das organizações (Foss \& Stieglitz, 2010), e considera que a base do conhecimento produtivo e organizacional da firma é as suas competências, as suas capacidades (capabilities) e as habilidades, sendo esses recursos fundamentais para a obtenção da vantagem competitiva sustentável (Kretzer et al., 2006). Newbert (2007), por exemplo, argumenta que o contexto de organização de uma empresa, suas capacidades dinâmicas e não seus recursos estáticos são essenciais para a compreensão de posições competitivas e rentabilidade superior.

Em contraste à visão focada nos recursos, essa vertente se baseia na dinâmica de aprendizagem, no conhecimento e em aspectos sociais, no sentido de que estejam ligados, de alguma forma, a uma coletividade de agentes que interagem (Felin \& Foss, 2005). Os autores dessa vertente tendem a colocar muita ênfase sobre a natureza tácita do conhecimento que, supostamente, reside na interação (Foss \& Stieglitz, 2010). Assim, capturam noções de "capacidades", "capacidades dinâmicas" e "rotinas". Capacidades dinâmicas são definidas como a capacidade da empresa para integrar, construir e reconfigurar competências internas e externas para resolver rapidamente ambientes em mudança (Teece, Pisano e Shuen, 1997). Logo, as capacidades dinâmicas refletem os processos de aprendizagem, como eles são um padrão aprendido de atividade coletiva através da qual a organização sistematicamente gera e modifica suas rotinas operacionais em busca de um melhor desempenho (Foss \& Stieglitz, 2010). 
2.3.3 Visão Baseada em Conhecimento (VBC) ou Knowledge Based View (KBV)

A ideia de que o conhecimento tem uma importância crucial para o desempenho e crescimento das empresas, regiões e países tornou-se nos últimos anos amplamente difundida (Malerba \& Orsenigo, 2000). É importante entender como o conhecimento pode ser caracterizado e como ele produz o seu impacto na economia. Ou seja, é necessário compreender as suas dimensões e, como consequência, quais são os mecanismos através dos quais o conhecimento melhora o bem-estar (Malerba \& Orsenigo, 2000).

Segundo Grant (1996) a VBC, observa o conhecimento como o recurso mais valioso e primordial para a criação de capacidades essenciais que gerem vantagens competitivas sustentáveis. Quando tratamos de recursos baseados no conhecimento, a blindagem contra a imitação está mais relacionada à sua própria natureza tácita e socialmente complexa do que ao regime de propriedade intelectual.

Segundo Teece (1998, p.57), “os ativos de conhecimento são, muitas vezes, inerentemente difíceis de copiar; ademais, como os ativos físicos, alguns ativos de conhecimento desfrutam de proteção contra furtos sob as leis de propriedade intelectual de nações individuais".

Diferentes tipos e formas de conhecimento são susceptíveis de exercer efeitos muito distintos sobre a forma como as atividades econômicas são organizadas, na produtividade e nas taxas globais de progresso tecnológico e econômico (Malerba \& Orsenigo, 2000). O conhecimento não pode simplesmente ser tratado como informação e aquisição de informações (Malerba \& Orsenigo, 2000). Segundo Hayek (1945), se todas as informações fossem conhecidas, as decisões seriam puramente matemáticas. Contudo, as informações são limitadas, muitas vezes restritas a pequenos grupos de indivíduos. Logo, temos o problema que o conhecimento de uma situação não é detido completamente por ninguém.

Existe uma estrutura conceitual em que as visões tradicionais e não tradicionais do conhecimento são integradas na teoria da criação do conhecimento organizacional. Segundo Nonaka e Takeuchi (1997), o conhecimento contém duas dimensões em sua estrutura conceitual: a epistemológica e ontológica. De acordo com a dimensão ontológica (Nonaka \& Takeuchi, 1997), em termos restritos, apenas indivíduos criam conhecimento, ou seja, uma organização não pode criar conhecimento sem indivíduos. Assim, a organização proporciona situações favoráveis e suporta os indivíduos para que eles gerem conhecimento. A criação do conhecimento organizacional deve ser entendida como um processo que amplia 
organizacionalmente o conhecimento criado pelos os indivíduos, cristalizando-o como parte das redes de conhecimento da organização.

$\mathrm{Na}$ dimensão epistemológica, estabelecida por Michael Polanyi (1983) entre conhecimento tático e conhecimento explícito, o conhecimento tático é pessoal e particular a uma situação, o que o torna difícil de ser formulado e comunicado. Diferentemente, o conhecimento explícito ou "codificado" é passível de ser comunicado por linguagem formal e sistemática.

Polanyi (1983) pondera que o conhecimento explícito representa apenas "a ponta do iceberg" do conhecimento adquirido e organizado pelo indivíduo a partir das suas experiências.

Os seres humanos criam conhecimento envolvendo-se com objetos, ou seja, através do envolvimento e compromisso pessoal (Polanyi, 1983). Portanto, a objetividade científica não constitui a única fonte de conhecimentos.

O debate sobre tacitividade contra codificação do conhecimento introduzido por Nelson e Winter (1982) chama a atenção dos economistas sobre o fato de que pode ser profundamente enganoso tratar o conhecimento como informação. Em vez disso, as atividades produtivas e inovadoras geralmente requerem o uso de recursos que não são adequadamente conceituados como informação, porque implicam o conhecimento que está estruturado e "embalado" de maneiras específicas. Assim, dois agentes dotados com a mesma informação podem muito bem acabar fazendo coisas diferentes (ou, até mesmo, fazendo a mesma coisa de uma melhor ou pior maneira), porque as estruturas cognitivas de indivíduos distintos ou grupos são susceptíveis de serem desenvolvidas através da experiência, a exposição a problemas particulares, etc., e, consequentemente, a sua compreensão cognitiva da informação é diferente (Malerba \& Orsenigo, 2000).

O conceito de conhecimento tácito tem sido usado para apoiar a busca por uma definição das noções de competências, competências essenciais, capacidades organizacionais e similares, que se tornaram nos últimos anos tão relevantes na literatura de gestão (Prahalad \& Hamel, 1990; Teece \& Pisano, 1994) e na teoria da firma (Nelson \& Winter, 1982; Winter, 1987; Chandler, 1992), com implicações importantes também para o comércio e teoria do crescimento (Malerba \& Orsenigo, 2000).

Em princípio, o conhecimento codificado é provável que tenha as propriedades de um bem público. Além disso, a codificação é susceptível de induzir, ceteris paribus, divisão do trabalho, por meio da redução dos custos de transação implicados na troca de conhecimentos entre diferentes agentes, permitindo que a modularização do conhecimento e, como 
consequência, a sua separabilidade e especialização em diferentes fases ou domínios dos processos de produção de conhecimento e uso por diferentes agentes (Malerba \& Orsenigo, 2000). A alegação aqui é que como o conhecimento torna-se codificado, torna-se mais fácil de transmiti-lo (Malerba \& Orsenigo, 2000). Como consequência, a divisão do trabalho é provável que surja e seja benéfica para o bem-estar. No entanto, embora, provavelmente, o conhecimento codificado se mostre mais fácil de transmitir do que o conhecimento tácito, essa proposição aplica-se estritamente apenas para o "mesmo" conhecimento (Malerba \& Orsenigo, 2000). Mais uma vez, há coisas que são difíceis para transmitir independentemente do seu grau de codificação (Malerba \& Orsenigo, 2000).

Por outro lado, quanto mais conhecimento é conceituado como tácito, mais a ênfase recai sobre a análise dos processos através dos quais os agentes individuais usam esse conhecimento para gerar novos produtos e processos que são inicialmente difíceis para os rivais de reproduzir e, assim, constituir variedade competitiva no sistema econômico (Malerba \& Orsenigo, 2000).

O reconhecimento do fato de que tacitividade ou codificação não são simplesmente propriedades do conhecimento como tal, mas são (pelo menos parcialmente) endógena, sendo influenciado por incentivos econômicos e outros processos sociais e institucionais, representa um grande passo em frente.

É necessário distinguir entre o conhecimento (tácito e codificado) e competências. A noção de competências foi desenvolvida como uma extensão da teoria original da RBV.

Competências correspondem a formas específicas de embalagem do conhecimento sobre coisas diferentes. Portanto, eles têm conteúdo organizacional intrínseco e implicações. Há uma diferença entre ter acesso a alguns conhecimentos e usar esse conhecimento para produzir produtos, serviços e novos conhecimentos. As competências podem ser simplesmente definidas como o conjunto de informação controlada por qualquer um agente (Malerba \& Orsenigo, 2000).

Basicamente, o conceito de competências tende a captar as ideias que (Malerba \& Orsenigo, 2000) agentes diferentes (empresas) sabem como fazer coisas diferentes de formas diferentes (domínios, os níveis de desempenho, etc.). Como tal, eles constituem uma das principais fontes de heterogeneidade entre as empresas e suas competitividades diferenciais.

O problema torna-se mais complexo, logo que seja reconhecido que o conhecimento é diferente da informação, na medida em que também inclui o conhecimento tácito do agente. Neste contexto, competências podem ser pensadas como a parte do conhecimento que não está codificado, mas é tácito (Malerba \& Orsenigo, 2000). A necessidade de distinguir entre 
conhecimento e competência surge, mais claramente, quando a questão das habilidades cognitivas dos agentes e da natureza de tais processos cognitivos é explicitamente considerada (Malerba \& Orsenigo, 2000). Em particular, surge com o reconhecimento de que:

a) Existem diferentes formas e graus de codificação e que a codificação implica a imposição de uma estrutura particular no conhecimento disponível.

b) $\mathrm{O}$ estoque de conhecimento de qualquer agente inclui conhecimento sobre diferentes coisas (domínios e funções) que têm de ser integrados para fins específicos.

Em um nível, o estoque de conhecimento de qualquer agente pertence a diferentes objetos (Dosi, Marengo \& Fagiolo, 1996), visões do mundo, propriedades da natureza, identidades de outros agentes, procedimentos para fazer as coisas (Malerba \& Orsenigo, 2000). Ou seja, o conhecimento é geralmente composto de vários domínios e conteúdos: disciplinas técnicas e científicas, conhecimento dos mercados específicos, conhecimento do ambiente institucional, etc. Assim, o "estoque de conhecimento" de qualquer agente é susceptível de ser sempre composto de várias partes, que podem ser integradas de diferentes maneiras e em diferentes graus, de acordo com a situação específica que agente enfrenta (Malerba \& Orsenigo, 2000). A esse respeito, as competências podem ser pensadas como a parte do conhecimento que se refere à ligação em conjunto dos vários pedaços de conhecimento tácito e codificado, que lhes permite ser mapeado sobre si através de códigos, linguagens e práticas (Malerba \& Orsenigo, 2000).

Competências poderiam ser entendidas como as formas através das quais o conhecimento é provocado, utilizado e aplicado a contextos e domínios específicos. Uma maneira ligeiramente diferente para reformular esta ideia consiste em reconhecer que existe uma diferença entre ter acesso ao conhecimento e usá-lo (Malerba \& Orsenigo, 2000). Com efeito, o conhecimento pode também ser definido como incluindo não só a acessibilidade, mas também o domínio (Malerba \& Orsenigo, 2000). Essa discussão é assumida na economia da informação, na qual se afirma que uma das principais propriedades da informação é que ela é cara para produzir, mas é reutilizável por tempo indeterminado, a custo zero (Malerba \& Orsenigo, 2000). No entanto, ele ainda pode ser útil para distinguir entre dois tipos de conhecimento: o conhecimento como insumo no processo de produção e o conhecimento como a capacidade de usar essas entradas no processo de transformação, finalizado na geração de novos artefatos e conhecimento (Malerba \& Orsenigo, 2000). 
Em outras palavras, o conhecimento codificado (como informações) certamente reduz os custos de aquisição de fragmentos particulares de conhecimento, mas a sua utilização efetiva pode também acarretar custos substanciais.

O conhecimento é usado para gerar novos conhecimentos, novos produtos, processos e serviços. Malerba e Orsenigo (2000) afirmam que outras dimensões do conhecimento, juntamente com a noção de processos de aprendizagem e de competências, são importantes para a compreensão da evolução das empresas:

i. Acessibilidade, a oportunidade de adquirir conhecimentos externo a empresas;

ii. Cumulatividade, à medida que novos conhecimentos se baseiam em conhecimentos atuais, e;

iii. Regime tecnológico, que inclui oportunidade, cumulatividade e apropriabilidade, bem como outras características do conhecimento da base de atividades inovadoras em uma indústria.

O conhecimento pode ter diferentes graus de acessibilidade e cumulatividade. A acessibilidade se refere a oportunidades de adquirir conhecimentos que são externos às empresas (Malerba \& Orsenigo, 2000). Esse conhecimento pode ser interno para a indústria (favorecendo, assim, a imitação dentro de uma indústria) ou externos a ela (afetando a disponibilidade de oportunidades tecnológicas para os operadores históricos e novas empresas). Em ambos os casos, a maior acessibilidade do conhecimento diminui a concentração de uma indústria (Malerba \& Orsenigo, 2000).

A acessibilidade do conhecimento externo para a indústria está relacionada com oportunidades científicas e tecnológicas. Aqui, o ambiente externo pode afetar as empresas através de capital humano em certo nível por meio do conhecimento científico ou tecnológico desenvolvido em empresas ou outras organizações, como universidades ou laboratórios de pesquisa (Malerba \& Orsenigo, 2000). Contudo, nem todo conhecimento externo pode ser facilmente usado e transformado em novos artefatos. Se o conhecimento externo é facilmente acessível, facilmente transformáveis em novos artefatos e expostos a uma grande quantidade de atores (tais como clientes ou fornecedores), então a entrada inovadora pode ter lugar (Winter, 1984).

Hayek (1945) expõe que este problema de acesso restrito a informações não foi tratado nos modelos econômicos puramente matemáticos. $\mathrm{O}$ autor trata dos aspectos do processo de 
planejamento, que são baseados em conhecimentos, surgindo, assim, a dificuldade de realizar o planejamento de maneira concentrada, uma vez que os conhecimentos são dispersos. Isso apenas leva a outro problema: indivíduos possuem conhecimentos únicos, que muitas vezes não serão transmitidos, o que leva a vantagens para a tomada de decisão nos casos específicos.

Já a cumulatividade do conhecimento significa algo diferente de acessibilidade: o grau em que a geração de novos conhecimentos se baseia em conhecimento atual. Podem-se identificar três diferentes fontes de cumulatividade (Malerba \& Orsenigo, 2000):

i. Processos dinâmicos de aprendizagem atrelados ao nível da tecnologia;

ii. Capacidades organizacionais. Estas capacidades são firmas-específicas e só podem ser melhoradas gradualmente ao longo do tempo. Elas definem implicitamente o que uma empresa aprende e o que pode esperar alcançar no futuro;

iii. Feedback do mercado.

De acordo com Malerba e Orsenigo (2000), algumas dimensões de acessibilidade e cumulatividade são bastante semelhantes em vários países, contudo, a capacidade de gerar e explorar condições de oportunidades é diferente em todos os países. Essa capacidade está relacionada com o nível e alcance da pesquisa universitária, a presença e a eficácia dos mecanismos de ciência e da indústria de ponta, ligações verticais e horizontais entre as empresas locais, e os tipos e níveis de esforços inovadores das empresas (Nelson, 1993) (Malerba \& Orsenigo, 2000).

Uma segunda característica do conhecimento está relacionada a seus domínios (Malerba \& Orsenigo, 2000), que podem variar drasticamente, afetando o tipo de competências e da concorrência em uma indústria (Malerba \& Orsenigo, 2000). Há uma distinção básica em relação à tecnologia e o conhecimento sobre a demanda. Assim, as empresas desenvolvem competências que são altamente setoriais e de tecnologia específica (Pavitt, 1990; Grandstand, 1998).

Outro domínio do conhecimento diz respeito a aplicações, usuários e demanda (Malerba \& Orsenigo, 2000). As empresas podem aprender as principais características dos usuários ao longo do tempo e desenvolver competências que estão relacionados com as características específicas de consumidores e demanda. Uma mudança na demanda, usuários e 
aplicações representa uma mudança no contexto em que as empresas operam e pode favorecer a entrada de novas empresas, em vez de o sucesso da já estabelecidas (Rosenbloom \& Christensen, 1994; Levinthal, 1998; Malerba \& Orsenigo, 2000).

A complementaridade de conhecimento foi mais um aspecto abordado por Malerba e Orsenigo (2000). Quando complementaridades do conhecimento estão presentes, a integração organizacional (e não a especialização) pode ocorrer por causa da necessidade de ter uma melhor coordenação e integração de diferentes capacidades complementares em inovações sistémicas (Malerba \& Orsenigo, 2000). Na verdade, um aspecto fundamental das atividades das empresas consiste na integração de diferentes peças de conhecimento (Pavitt, 1998) através de capacidades de coordenação e integração, devido à complementaridade, em especial no caso de inovações sistêmicas.

Sempre que o conhecimento subjacente das atividades das empresas tem um forte componente tácito, ou ainda, existem custos de transações, que podem ser muito alto diante de rápida mudança ou inovação, nas trocas de informações codificadas, negociações, e, cordenação e transmissão de conhecimentos aos atores externos, as empresas tendem a decidir pela integração vertical (Langlois \& Robertson, 1996; Teece, 1986a).

\subsubsection{A Governança do Conhecimento}

A governança do conhecimento permeia as diversas áreas da gestão (Foss \& Mahoney, 2010). Em particular, representa um cruzamento de gestão do conhecimento, gestão estratégica e as teorias da firma. Davenport e Prusak (1999) descrevem a gestão do conhecimento como uma ação baseada em recursos existentes, como gestão de sistemas de informação, de mudança organizacional e de recursos humanos. Já para Bukowitz e Williams (2002), é o do processo pelo qual a organização gera riqueza, a partir do seu conhecimento ou capital intelectual.

A governança do conhecimento representa a convergência da economia organizacional (economia de custos de transação, direitos de propriedade, e a teoria da agência) e o ponto de vista do conhecimento em gestão estratégica, bem como a interface emergente entre a gestão do conhecimento e perspectivas da teoria de organização e comportamento organizacional (Foss, 2007).

A governança do conhecimento considera como a implantação de mecanismos de governança influenciam processos de conhecimento (partilha, retenção e criação), e vice- 
versa (Foss \& Mahoney, 2010). Probst, Raub e Romhardt (2002) definem como métodos para influenciar os ativos intelectuais da organização e orientar seu desenvolvimento. Logo, podese definir a gestão do conhecimento como um processo sistemático de identificação, criação, renovação e aplicação dos conhecimentos de uma organização, que são estratégicos para o seu desempenho.

Observa-se em distintos cenários que o conhecimento produz alguns problemas transacionais nas firmas, entre eles a dificuldade de se medir o produto marginal de cada participante no processo de criação do conhecimento, dificuldades de se apurar os resultados e assimetria de informação.

Processos de conhecimentos têm uma série de características importantes que são particularmente difíceis, tais como: (i) os elementos significativos da equipe de produção (Alchian \& Demsetz, 1972; Lindenberg, 2003) que tornam difícil medir o produto marginal de cada participante nos processos de criação e compartilhamento do conhecimento, (ii) dificuldades de apuração do resultado, (iii) problemas de informação assimétrica, e (iv) planos detalhados de contingências para processos de conhecimento podem ser extremamente caro de desenhar. Há uma tendência na literatura para explicar o desenvolvimento de capacidades em termos de capacidades anteriores, ou seja, a capacidade de absorção da empresa em $\mathrm{t}+1$ é explicada em termos de capacidade de absorção no tempo t. Como Felin e Foss (2005) apontam, no entanto, esta abordagem equivale a explicar uma variável agregada apenas em termos de outra variável agregada, sem incorporar na explicação o papel da interação individual, estruturado pela organização. Foss e Mahoney (2010) destacam a importância da governança do conhecimento ocorre não somente dentro das firmas, como entre firmas, formando alianças estratégicas.

Assim, nota-se que há um fluxo de pesquisas distintas, indicando a tentativa de ir mais longe e pensar sobre o entrelaçamento do conhecimento e da organização de uma forma unida e mais sistemática. Um ponto de partida é a convergência entre a economia organizacional e a VBC no gerenciamento estratégico (Grandori, 2001; Foss, 2003; Nickerson \& Zenger, 2004). Cada vez mais as pesquisas começaram a examinar as motivações dos indivíduos para usar, compartilhar, construir e integrar o conhecimento, considerando como o comportamento e interação moldam os processos de conhecimento.

Pode-se dizer, portanto, que a governança do conhecimento significa a implantação de mecanismos que atenuem os custos de criação e compartilhamento de conhecimento, devido às características acima de conhecimento (Heiman \& Nickerson, 2002). Governança do conhecimento, portanto, significa escolher estruturas de governança (por exemplo, mercados, 
híbridos, hierarquias) e de mecanismos de coordenação (por exemplo, contratos, diretivas, esquemas de recompensa, incentivos, confiança, estilos de gestão e cultura organizacional), de forma a maximizar os benefícios líquidos dos processos de transferência, compartilhamento e criação de conhecimento. Estruturas de governança e mecanismos de governação são importantes porque definem os incentivos e coordenar as ações dos membros organizacionais em processos de conhecimento.

\subsubsection{Distância transfronteiriça}

Há décadas, a distância entre as nações é utilizada como uma das principais variáveis explicativas no modo de internacionalização das empresas (Werner, 2002). Hymer (1960) observou que um fator chave na internacionalização da empresa é o chamado "foreign responsabilities", que aumenta com a distância entre os países de origem e de acolhimento. $\mathrm{O}$ paradigma eclético (Dunning, 1993) também chamou a atenção para a distância internacional, propondo uma perspectiva multidimensional, na qual os países podem ser distantes não só no sentido geográfico, mas também nas diferenças econômicas, sociais, culturais ou políticas, tornando mais difícil para as empresas operar por meio delas.

Johanson e Vahlne (1977, p. 24) mencionaram as "diferenças de língua, educação, práticas de negócios, cultura e desenvolvimento industrial" como dimensões relevantes para a diferença entre os países. Kogut e Singh (1988, p. 413) referiram-se genericamente às "características de um mercado estrangeiro". Por seu lado, Barkema, Bell e Pennings (1996, p. 153) referem-se aos "fatores linguísticos, institucionais, culturais e políticos", mas em termos de distância de blocos culturais dos países. Por último, Hennart e Larimo (1998, p. 517) se aproximaram do conceito de distância na perspectiva de custos de transação, restringindo a sua definição para "características culturais nacionais de origem e de acolhimento países".

A suposição geral, na maioria desses estudos, é que quanto mais diferente o ambiente externo quando comparado ao país de origem de uma empresa, mais difícil será para coletar, analisar e interpretar corretamente informações sobre ele, aumentando, portanto, as incertezas e dificuldades, tanto reais quanto esperadas. O mesmo ocorre com o custo de fazer negócios através das fronteiras, isto é, os custos de transação associados aos negócios internacionais, uma vez que os tomadores de decisão podem subestimar sistematicamente diferenças reais para países percebidos como muito semelhante ao do país de origem (O'Grady \& Lane, 1996; Fenwick, Edwards, \& Buckley, 2003), ou também exagerar nas percepções de distância, 
levando os gestores a renunciar oportunidades de negócios rentáveis no exterior (Håkanson \& Ambos, 2010).

As culturas nacionais também influenciam a forma como as organizações percebem a incerteza ambiental e, portanto, afetam seu modo de interpretar e responder a questões estratégicas (Schneider \& De Meyer, 1991).

Embora reconhecendo conceitualmente a natureza multidimensional da distância, a maioria dos estudiosos de negócios internacionais realizou trabalhos empíricos sobre a distância entre países efetivamente prestando atenção a uma única dimensão, na análise empírica, a cultural.

\subsubsection{Distância Cultural}

Cultura é definida como um conjunto de suposições, expectativas ou regras tomadas como certas para estar no mundo, seja no nível nacional ou organizacional. O conceito de cultura enfatiza a abordagem cognitiva partilhada com a realidade que distingue um determinado grupo de outros (Adler \& Jelinek, 1986).

Estudos de comparações transnacionais estão preocupados com como a cultura de um país influencia os negócios internacionais, ou seja, a ligação entre a cultura e o comportamento ou atitudes de indivíduos e grupos em organizações ou o comportamento das organizações como entidades. Sob a suposição de que as fronteiras culturais foram assumidas para coincidir com as fronteiras nacionais, a identidade nacional (e, portanto, cultural) foi admitida como uma dada característica única e imutável de um indivíduo (Dakessian, 2014). Assume-se a cultura como sendo um conjunto coerente e duradouro de valores que agem sobre os membros de um Estado-nação (Boyacigiller et al., 2007).

De acordo com Hofstede (1980, p. 13), a cultura é a "programação coletiva da mente que distingue os membros de um grupo humano de outro". Já, para Fons Trompenaars e Hampden-Turner (1998, p. 6), a cultura é "o caminho em que um grupo de pessoas resolve problemas e reconcilia dilemas". Ronen e Shenkar (2013, p. 868) consideram que as instituições políticas, econômicas, sociais e regulatórias determinam o poder do Estado-nação, sendo um delimitador cultural. Assim, definem a cultura como "uma forma de vida compartilhada de um grupo de pessoas socialmente interagindo, transmitido de uma geração para a próxima via de aculturação e socialização processos que distinguem os membros de um grupo de outras pessoas". 
Considerando-se a importância do ambiente de negócios cada vez mais globalizado, tanto para as empresas como para os países, a compreensão do impacto das interações interculturais e da influência mútua de pessoas de diferentes nações em contextos organizacionais, mostra-se fundamental.

Estudos sobre negócios internacionais têm abordado o impacto das distâncias das culturas nacionais nos mais diversos temas de pesquisa: escolha de mercados para exportação e modos de entrada nos mercados estrangeiros (Harzing, 2004), a concepção de práticas de gestão de recursos humanos (Bjorkman \& Furu, 2000; Rosenzweig \& Nohira, 1994), o poder de distribuidores dos mercados estrangeiros (Griffith \& Harvey, 2001), táticas de negociação (Rao \& Schmidt, 1998), a disposição para investir em pesquisa e desenvolvimento em subsidiárias nos países hospedeiros (Mumlidharan \& Phatak, 1999) e a concepção de práticas de transferência de conhecimentos (Minbaeva, Pedersen, Björkman, Fey, \& Park, 2003; Simonin, 1999), entre outros.

A abordagem mais amplamente utilizada para a distância transfronteiriça é baseada nas quatro dimensões culturais de Geert Hofstede, originalmente disponibilizadas em consequência ao seu trabalho publicado em 1980. Hofstede $(1980,1997)$, realizou um grande levantamento de dados, em mais de 50 países ao redor do mundo, através de um questionário aplicado entre 1967 e 1973 entre os gerentes das filiais da IBM ao redor do mundo. Aproveitando-se do fato de que, de um país para outro, eles mostraram semelhanças em todos os aspectos, exceto nacionalidade, os efeitos de suas diferenças de nacionalidade eram extraordinariamente claros sobre as suas respostas às perguntas que foram formuladas em uma série de pesquisas. A análise estatística das respostas revelou problemas comuns com soluções diferentes de país para país em quatro áreas-chave, que Hofstede (1997) analisou como os aspectos distintivos chave da cultura nacional e chamou de dimensões culturais:

i. Distância ao poder - a relação com autoridade, o grau em que os membros menos poderosos de instituições e organizações esperar e aceitar que o poder é distribuído de forma desigual;

ii. Aversão à incerteza - formas de lidar com a incerteza, relacionada ao controle da agressão e a expressão das emoções, pode ser definida como o grau em que os membros de uma cultura se sentem ameaçados por situações incertas ou desconhecidas, um sentimento que pode ser expresso através de um estresse nervoso e em uma necessidade de regras escritas e não escritas; 
iii. Individualismo - a relação entre o indivíduo e o grupo, diz respeito a sociedades em que os laços entre os indivíduos estão soltos, em contraste com as sociedades coletivas em que as pessoas (desde o nascimento) são integradas fortemente agrupos;

iv. Masculinidade - sociedades masculinas são aqueles em que os papéis sociais de gênero são claramente distintos - os homens devem ser assertivo, fortes e focados no sucesso material, enquanto as mulheres são supostamente modestas, sensíveis e preocupadas com a qualidade de vida - e o oposto, as sociedades femininas, são aqueles em que os papéis sociais de género são semelhantes e ambos, homens e mulheres, devem ser modestos, sensíveis e preocupados com a qualidade de vida.

Enquanto muitos estudiosos de gestão têm adotado as dimensões culturais de Hofstede como a base das medidas de distâncias transfronteiriças, críticas a esta abordagem são abundantes (Guille'n \& Suarez, 2001; Shenkar, 2001; Lee \& Soutar, 2007; Baskerville, 2003). Em primeiro lugar, Hofstede reduziu todas as diferenças entre os países para a dimensão da cultura, falhando assim para capturar a rica variedade de dimensões ao longo do qual os países diferem uns dos outros (Ghemawat, 2001), como economia, língua, religião, e fatores legais (Tang \& Koveos, 2008; Berry; Guillén \& Zhou, 2010). Em segundo lugar, Hofstede assumiu que as distâncias entre países não mudam ao longo do tempo (Berry et al., 2010), entretanto, pesquisas sociológicas recentes demonstram que a distância cultural, econômica ou política, por si só, podem mudar ao longo do tempo de forma bastante rápida (Inglehart \& Baker, 2000; Shenkar, 2001; Webber, 1969). Em terceiro lugar, quando os pesquisadores usam medidas culturais de Hofstede para estudar o comportamento dos gestores individuais, eles podem incorrer em um erro de interpretação, ao assumir que os membros individuais de um grupo têm as características médias da população em geral (Berry et al., 2010). Em quarto lugar, e relacionado com a terceira crítica, Hofstede assumiu que os gestores de uma única corporação (ou seja, IBM) são representativos da população total em um determinado país (Lu, 2006; Smith, 1996; Berry et al., 2010). Além disso, é possível que a distância cultural percebida pelos empregados em uma organização intercultural, como a IBM é menor do que a distância cultural real entre os dois países, devido às interações entre os empregados da mesma companhia (Lu, 2006; Berry et al., 2010).

Em 1988, Bruce Kogut, professor visitante do Instituto de Negócios Internacionais na Escola de Economia de Estocolmo, e Harbir Singh, da Wharton School of Business, publicaram um artigo no Jornal de Estudos de Negócios Internacionais em que a sua 
proposição central foi avaliar o efeito da cultura nacional sobre a escolha do modo de entrada. A suposição do estudo era de que as diferenças de culturas entre os países de origem e de acolhimento influenciam a percepção dos gestores quanto aos custos e incerteza dos modos alternativos de entrada em mercados estrangeiros. Kogut e Singh (1988) propuseram um procedimento para medir o índice de diferença cultural [CD], de forma a utilizá-lo como uma variável independente em seu modelo, baseado no desvio de cada uma das quatro dimensões escalas culturais nacionais de Hofstede: distância do poder, aversão à incerteza, masculinidade e individualismo. Matematicamente, o seu índice de distância cultural é determinado como se segue:

$$
C D_{j k}=\sum_{i=1}^{4} \frac{1}{4}\left[\frac{\left(I_{i j}-I_{i k}\right)^{2}}{V_{i}}\right]
$$

em que $C D$ é a distância cultural entre os países $\mathrm{j}$ e $\mathrm{k}, \mathrm{I}_{\mathrm{ij}}$ é o índice para a $\mathrm{i}^{\text {th }}$ dimensão cultural para o país jth $\mathrm{j}_{\mathrm{ik}}$ é o índice para a dimensão cultural do país $\mathrm{k}$, e $\mathrm{V}_{\mathrm{i}}$ é a variância para a dimensão cultura. Sua suposta decisão de impor pesos com base na variação do índice se deu com o fim de evitar correlações indesejáveis entre erros de medição e outras variáveis independentes.

Não obstante, a principal desvantagem do índice de Kogut e Singh, assim como Hofstede, encontra-se no cálculo da percepção de distância baseado apenas nas características culturais (Shenkar, 2001; Yeganeh \& Su, 2006). O estudo de Kogut e Singh acabou por ser um dos trabalhos mais citados na literatura de negócios internacionais e o índice teve uma aceitação generalizada entre os investigadores, dada a sua conveniência inerente ao ser empregues em modelos estatísticos.

Além de extensões do trabalho de Kogut e Singh (Slangen \& Hennart, 2008), esse índice tem sido utilizado em uma variedade de outras questões teóricas, tais como o impacto das diferenças culturais nacionais sobre a longevidade de entradas de estrangeiros (Barkema et al. 1996), as motivações por trás das dissoluções de joint venture (Park \& Ungson, 1997), as preferências para o licenciamento de investimentos diretos no exterior (Shane, 1992), o efeito da distância cultural sobre o desempenho da empresa (Gomez-Mejia \& Palich, 1997), e na investigação dos efeitos da distância cultural sobre o desempenho de fusões e aquisições (Dakessian \& Feldmann, 2013; Dakessian, 2014; Morosini, Shane, \& Singh, 1998; Slangen, 2006; Weber, Shenkar, \& Raveh, 1996). 
Fons Trompenaars e Hampden-Turner (1998), partindo de uma visão conceitual semelhante de Hofstede, propuseram uma estrutura baseada em sete dimensões que definem o conjunto compartilhado de valores e normas que orientam comportamento de cada país, no entanto, eles diferem de Hofstede quanto aos valores que acreditam capturar essas diferenças nacionais. Os autores consideram cinco dimensões decorrentes dos estudos sociológicos realizados por Parsons (1951): universalismo / particularismo; individualismo/coletivismo; afetividade (neutro/emocional); especificidade (específico/difusa); realização / atribuição; atitudes em relação ao tempo; e, atitudes em relação ao ambiente. Os dados foram coletados por meio de pesquisa realizada entre 1980 e 1990, envolvendo gestores em 54 países (Magnusson, Wilson, Zdravkovic, Zhou, \& Westjohn, 2008; Uhlenbruck, 2004).

Alternativa para a abordagem de Hofstede, o estudo GLOBE foi realizado durante a década de 1990 (House, Hanges, Javidan, Dorfman, \& Gupta, 2004). Destinava-se a conceituar, operacionalizar, testar e validar as relações entre cultura, liderança, eficácia organizacional, a competitividade econômica das sociedades, e da condição humana de membros das sociedades envolvidas no projeto (House \& Javidan, 2004).

A abordagem de GLOBE desenvolveu nove dimensões culturais a partir de uma revisão da teoria organizacional e cultural existente. O questionário foi aplicado a gerentes de nível médio em várias organizações, concorrentes em serviços financeiros, processamento de alimentos e indústrias de telecomunicações e localizadas em 58 países. As respostas foram analisadas por procedimentos psicométricos convencionais, tais como análise de itens, análise fatorial, análise de cluster e análise de generalização (House et al., 2004; Magnusson et al., 2008; Dakessian, 2014).

Apesar de ser mais abrangente e recente do que o estudo de Hofstede, GLOBE sofre os mesmos problemas de uni dimensionalidade, invariância tempo, e representatividade. Hofstede (2006) comparou as semelhanças e diferenças entre GLOBE e sua abordagem, concluindo que, apesar de uma abordagem muito diferente, o estudo GLOBE ainda reflete a estrutura de seu modelo original (Berry et al., 2010).

Em suma, os estudos sobre a distância transfronteiriça tendem a ser unidimensional e invariante no tempo, baseando as suas medidas em dados que não são totalmente representativos das características ricas e diversificadas dos países, e, oferecendo dados para menos de um terço do número total de países em todo o mundo. Além disso, o método de cálculo utilizado, geralmente, não leva em consideração as diferenças nas escalas de medição ou correlações entre as variáveis subjacentes (Berry et al., 2010). De acordo com Berry et 
al.(2010), a caracterização limitada da distância cultural não é suficiente para captar as múltiplas formas em que os países diferem uns dos outros.

\subsubsection{Distância Psíquica}

Distância cultural e distância psíquica são conceitos que têm sido usados de forma equivalente, sem distinção entre eles. Entretanto, trata-se de construções, conceitualmente, diferentes e capturam fenômenos distintos, mas, sobrepostos (Brewer, 2007; Dow \& Karunaratna, 2006; Evans, Treadgold, \& Mavondo, 2000; Håkanson \& Ambos, 2010; Smith, Dowling, \& Rose, 2011; Sousa \& Bradley, 2006; Vahlne \& Nordström, 1992; Dakessian, 2014).

A escola comportamental de Simon (1947), March e Simon (1993), Cyert e March (1963) e Aharoni (1966), propiciaram importante contribuição, para os estudos de negócios internacionais ao impor a ideia de que os processos de internacionalização (e outras transações internacionais) não são apenas determinados pelas realidades econômicas objetivas, mas são influenciadas também pela disponibilidade de informações e pelas capacidades cognitivas daqueles que tomam as decisões nas empresas. Nesta linha de raciocínio, o conceito de distância psíquica foi introduzido na literatura por Beckerman (1956, p. 36), como uma "distância subjetivamente percebida em país estrangeiro", em estudo no qual ele abordou a questão da distância na determinação do padrão de comércio da Europa Ocidental. $\mathrm{O}$ autor apresenta que além de barreiras geográficas, o comércio internacional também pode ser afetado por barreiras de distância psíquica. Linnemann (1966), em um estudo econométrico dos fluxos comerciais internacionais, também indicou a distância psíquica como um fator que aflige o comércio internacional.

Mas o que é a distância psíquica? O conceito de distância psíquica ganhou proeminência em meados da década de 1970, com a introdução da teoria da internacionalização pelos membros da escola de Uppsala, na Suécia. Especificamente, ganhou destaque nos trabalhos de autores, como Johanson e Wiedersheim-Paul (1975), e em particular por Johanson e Vahlne (1977). Para Johanson e Vahlne (1977), a distância psíquica é a soma de fatores que impedem o fluxo de informações entre os mercados, ou seja, diferenças de língua, cultura, sistemas políticos, educação, níveis de atividade industrial e desenvolvimento afetam os negócios, assim como os fluxos de investimentos e outras formas de produção internacional. Tais diferenças podem impedir ou pelo menos perturbar os fluxos 
de informação entre empresas e mercado. Com o tempo, diversas definições foram debatidas (Brewer, 2007; Evans \& Mavondo, 2002; O 'Grady \& Lane, 1996) enfatizando questões como percepções contra diferenças reais, e a distinção entre distâncias e diferenças. De acordo com Joliet e Hubner (2003), a distância psíquica é a distância percebida entre o país de origem e um país estrangeiro, resultante das diferenças em termos de cultura, negócios, políticas, ou seja, diferenças na linguagem, sistemas políticos e legais, na prática do comércio, na estrutura da indústria, etc.

Na conceituação da escola Uppsala (Hörnell et al., 1973), a distância psíquica é uma categoria cognitiva de capturar o conhecimento e a quantidade de informações que os indivíduos têm (ou acreditam que têm) de outros países. Seus principais determinantes são, portanto, o custo ou dificuldade de obtenção de informações relevantes e precisas sobre as condições de negócios de mercados estrangeiros. Nessa linha de raciocínio, a distância psíquica afeta as decisões sobre as atividades estrangeiras, impedindo que os gestores tomem decisões economicamente racionais com conhecimento de causa (Berry et al., 2010). Diferenças de cultura são potencialmente problemáticas principalmente porque elas aumentam requisitos de informação e os custos de pesquisa. A prática seguida posteriormente na literatura para tratar a distância cultural como sinônimo ou como proxy para a distância psíquica tira a ênfase do papel do acesso à informação em favor de um foco sobre os custos (adicionais) que os gestores acreditam estar associados com operações em um ambiente culturalmente desconhecido. De acordo com Kogut e Singh (1988), tais custos podem ser perceptuais ou apenas avaliações precisas do aumento das dificuldades de gerenciar uma força de trabalho estrangeira em países culturalmente distantes. Em contraste com a escola de Uppsala, esta abordagem assume que os custos e disponibilidade de informação relevante sobre os diferentes países diferem apenas marginalmente e que os principais desafios de fazer negócios no exterior estão associados com diferenças absolutas nas culturas dos países

As diferenças culturais entre os países são simetricamente definidas, assumindo implicitamente que as dificuldades de transferência e adaptação das práticas de negócios entre quaisquer dois países são os mesmos, independentemente da direção (Håkanson \& Ambos, 2010). Håkanson e Ambos (2010) assumem que as percepções de distância psíquica são formadas com base em estímulos ambientais, principalmente a quantidade e o tipo de conhecimento que uma pessoa possui (ou acredita possuir) sobre um país estrangeiro. Este, por sua vez, será ser influenciado por uma série de fatores, muitos dos quais são historicamente determinantes. Segundo os autores, por exemplo, a linguagem comum pode, muitas vezes, ser um legado dos antigos laços coloniais e é significativo não só para facilitar a 
comunicação e troca de informações; muitas vezes é associado também com mais profundas afinidades culturais que afetam a percepção distância psíquica (Brewer, 2007).

O valor e a utilidade da informação sobre um país estrangeiro dependem não só da sua quantidade e conteúdo, mas também da capacidade do destinatário para interpretá-la corretamente. Isto tenderá a ser mais difícil quanto mais diferente o contexto cultural e institucional a que se refere à informação. As diferenças culturais são importantes, na medida em que afetam as habilidades de um indivíduo de compreender intelectualmente e relacionar emocionalmente com as condições em países estrangeiros. Quanto mais familiar um país estrangeiro do país de origem (ou de outros países com os quais o sujeito está familiarizado), menor é a distância psíquica (Håkanson \& Ambos, 2010).

Enquanto a distância cultural é um fenômeno coletivo relacionado a diferenças nacionais em normas e valores compartilhados (Drogendijk \& Slangen, 2006; Hofstede, 1980, 1997), a distância psíquica é conceituada no nível individual e é, geralmente, concebida como um fenômeno perceptivo e cognitivo, associado não só às diferenças culturais nacionais entre dois países, mas também a outros fatores que podem dificultar o fluxo de informação entre estes países e afetar a capacidade dos indivíduos para interpretar essas informações, tais como religião dominante, linguagem de negócios, forma de governo, o desenvolvimento econômico e os níveis de emigração (Boyacigiller, 1990; Dakessian, 2014). Não obstante o fato de que o indivíduo é a unidade de análise apropriada quando se mede a distância psíquica, as medidas nacionais de distância psíquica devem ser entendidas como a distância psíquica média realizada pela comunidade empresarial de um país estrangeiro particular (Dow \& Karunaratna, 2006; Håkanson \& Ambos, 2010; Smith et al., 2011).

Em uma tentativa de construir um instrumento multidimensional abrangente para medir a distância psíquica, Dow e Karunaratna (2006) desenvolveram e testaram uma ampla seleção de indicadores, tais como diferenças de língua, religião e sistemas políticos - além das medidas tradicionais de dimensões culturais de Hofstede - que formam o contexto no qual a percepção de distância psíquica dos gestores é formada e, portanto, pode influenciar as decisões internacionais sobre a seleção mercado de exportação (Dakessian, 2014).

Usando como variável dependente os dados dos fluxos comerciais entre um conjunto de 38 países, eles apresentaram que a maioria dos indicadores propostos se mostraram estatisticamente significantes na análise dos de fluxos comerciais, enquanto uma medida composta com base nas dimensões culturais de Hofstede acabou por ser não significativa. Håkanson e Ambos (2010) investigaram os potenciais impulsionadores da percepção da construção da distância psíquica, com base em dados de 25 das maiores economias do mundo. 
Eles concluem que essas percepções são influenciadas por uma série de fatores culturais, geográficos, políticos e econômicos. Entre as variáveis de previsão está distância geográfica, explicando a maior parte da variação, sugerindo que a distância física deve ser dada um papel mais proeminente para investigar empiricamente decisões de negócios internacionais - como as decisões sobre mercado externo e seleções de países-alvo e os modos de entrada, entre outros - para a qual distância psíquica pode ser relevante.

Håkanson e Ambos (2010) demonstraram que a distância psíquica percebida é influenciada por um conjunto complexo de fatores e não pode de forma fiável ser aproximada por diferenças culturais isoladamente. Tais resultados validam críticas empiricamente recentes do índice de distância cultural de Kogut e Singh (1988) com base em considerações teóricas (Shenkar, 2001). Estudos que tentam capturar distâncias de percepção por meio de um índice de distância cultural simples correm o risco de cometer erros de atribuição, quanto à influência da distância psíquica em fenômenos como a seleção de mercado de exportação, modos de entrada ou o desempenho de subsidiária estrangeira. Outra implicação importante da pesquisa de Håkanson e Ambos (2010) é que fica claro que a proximidade geográfica e os fatores econômicos são antecedentes poderosos de distâncias psíquicas percebidas entre países. Segundo o resultado da pesquisa a distância geográfica simples acaba por ser mais de três vezes mais importante do que a distância cultural como medida pelo índice Kogut e Singh.

\subsubsection{Distância Institucional}

Os mercados reais estão longe de serem perfeitos, consequentemente, as instituições importam (North, 1990; Williamson, 1985). Instituições afetam os custos de transação e de coordenação relativos de produção e inovação, para não mencionar a concorrência entre os sistemas institucionais como alguns deles provaram ser bem-sucedida na promoção do crescimento, concorrência e abertura, enquanto outros perderam para fora e não conseguiram alcançar esses resultados (Mudambi \& Navarra, 2002). North (1990) apontou que as estruturas institucionais complexas têm sido desenvolvidas ao longo do tempo para restringir ações de agentes sociais e reduzir a incerteza de interação social. Essas instituições incluem contratos formais e garantias, as leis de falência, e direitos de propriedade definidos e efetivamente protegidos, marcas e organizações empresariais. As instituições que uma sociedade desenvolve são instrumentos cruciais para o comércio de longa distância. Essas 
instituições facilitam o crescimento econômico, os investimentos internacionais e o fluxo de comércio. As instituições ajudam a, reduzir o oportunismo nas transações entre pessoas desconhecidas umas das outras e fornecem um modelo para a criação multilateral reputação, apoiados por estruturas de credível compromisso, aplicação e coordenação (Mudambi \& Navarra, 2002).

De acordo com os teóricos institucionais, as instituições são issue-specific e, portanto, as características institucionais de um país devem ser avaliadas em relação a um fenômeno específico em vez de em termos gerais (Kostova, 1997). As variações no ambiente institucional dos diversos países acrescentam incerteza a novas operações estrangeiras que, por sua vez, eleva a taxa mínima de retorno e desencoraja a entrada. Mercados que são semelhantes em estruturas política, de mercado, de fatores e da cultura representam menor incerteza, e, relativamente baixos custos de entrada, portanto, os obstáculos para a rentabilidade são menores. As empresas que investem são mais propensas a entrar em países onde o regime político é relativamente fácil de prever e são menos propensas a entrar em países que são culturalmente distantes e têm estruturas organizacionais diferentes.

Outra fonte de incerteza é a instabilidade no nível do processo de tomada de decisão em países com regimes instáveis, em particular, sobre os impactos dos riscos políticos e o oportunismo que as empresas multinacionais enfrentam devido a compromissos do governo para estruturas de dados de tributação e regulamentação ou mesmo um conjunto de direitos de propriedade (Mudambi \& Navarra, 2002).

A fim de captar a rica diversidade de formas em que os países diferem, os estudiosos de negócios internacionais têm se dedicado a conceituar, medir e analisar a influência da distância transfronteiriça baseado na teoria da análise institucional.

As características institucionais de um país refletem os vários aspectos deste, incluindo normas culturais, conhecimento social, regulamentos e outros (Scott, 1995). De acordo com Scott (1995), ambientes institucionais são compostos por três principais tipos de instituições, ou pilares: regulamentar, cognitivas e normativas. O componente regulamentar reflete as leis e regras existentes em um ambiente nacional que promovem certos tipos de comportamentos e restringem outros. O componente cognitivo reflete as estruturas cognitivas e conhecimento social compartilhado pelas pessoas de um determinado país. Eles afetam o comportamento individual como eles moldam os programas cognitivos (esquemas, quadros e conjuntos inferencial) que as pessoas usam quando selecionar e interpretar informações. O componente normativo consiste em normas sociais, valores, crenças e suposições sobre a natureza e o comportamento humano que são socialmente compartilhados e são realizadas por indivíduos, 
sendo que alguns pesquisadores realizaram estudos neste sentido (Meyer \& Rowan, 1977; Scott, 1995; Zucker, 1991).

O conceito de perfil institucional do país e os contextos organizacionais e relacionais foram utilizados por Kostova (1997/ 1999), para formular uma série de proposições sobre a transferência transnacional de práticas organizacionais estratégicas. Já a distância institucional (ou perfil institucional) entre os países de acolhimento e de origem nas dimensões regulatórias, normativas e cognitivas das instituições foram decompostas por Xu e Shenkar (2002), que ajustaram estas aos atributos da empresa para formular proposições relativas à seleção do país anfitrião e estratégias de entrada no mercado externo. Inúmeros estudos têm abordado a importância das instituições para a compreensão de estratégia de negócios e desempenho através das fronteiras nacionais (Berry et al., 2010; Bevan, Estrin, \& Meyer, 2004; Jackson \& Deeg, 2008; Mudambi \& Navarra, 2002).

A teoria econômica neoclássica tradicional postula que a vantagem competitiva de um determinado local pode ser avaliada por suas condições macroeconômicas, ignorando ou tratando apenas como fatores secundários as variações nas estruturas institucionais entre países.

Considerando a importancia das instituições, uma das tentativas mais abrangentes de ampliar o estudo da distância entre as nações se encontra na abordagem de quatro dimensões de Ghemawat (2001), cultural, administrativa, geográfica e distância econômica. Embora esse artigo tenha mudado a maneira pela qual os pesquisadores de estratégia e de negócios internacionais observam a questão da distância cross-nacionais, concentrando a atenção sobre a sua natureza multidimensional, não foi suficientemente longe no reconhecimento das complexidades de distância, uma vez que ele não levou em consideração finanças, política, demográfia, conhecimento ou conexão global, e não forneceu orientação sobre como medir cada dimensão.

Já, Berry et al. (2010) fornecem um quadro teórico que acomoda as diferentes dimensões, baseadas nas teorias institucionais, ao longo do qual os países diferem uns dos outros. Seguindo a recente teorização institucional no campo dos negócios internacionais (Jackson \& Deeg, 2008; Pajunen, 2008), basearam a abordagem em três perspectivas teóricas. A primeira perspectiva teórica na distância cross-nacional foi lançada por Richard Whitley (1992), e é focada no conceito de "sistemas empresariais nacionais". A segunda foi formulada pelos estudiosos Witold Henisz e Oliver Williamson (1999), e por Rafael La Porta, Florencio Lopez-de-Silanes, Andrei Shleifer e Robert Vishny (1998). Ela enfatiza as implicações das diferenças entre os sistemas nacionais de governança. A terceira foi proposta por Richard 
Nelson e Nathan Rosenberg (1993), observando os sistemas de negócios nacionais como “arranjos especiais nas relações de hierarquia de mercado" (Whitley, 1992, p. 10). Os países diferem em graus variados em termos das características de seus sistemas de negócios, especificamente suas práticas econômicas, financeiras e administrativas. Whitley (1992) argumentou que tais diferenças têm origem em instituições demográficas, geográficas, culturais e políticas, que fazem alguns países mais diferentes, ou distantes, do que outros de um determinado país focal, uma característica que afeta decisões gerenciais.

Um segundo impulso importante na literatura sobre instituições transnacionais trata de governança. Os sistemas nacionais de governança referem-se aos "conjuntos de incentivos, salvaguardas e resolução de disputas processos usados para ordenar as atividades de várias partes interessadas" (Kester, 1996, p. 109), tais como proprietários (ou sociedade), gestores, trabalhadores, credores, fornecedores e clientes. Eles se originam nas instituições administrativas e políticas que historicamente fazem certas partes interessadas mais poderosas em certos países do que em outros (Glendon, Gordon, \& Osakwe, 1994; Henisz, 2000; Henisz \& Williamson, 1999; La Porta et al., 1998). Dimensões de governança também são relevantes para decisões gerenciais, porque as empresas precisam estabelecer relações com as partes interessadas, a fim de operar em um determinado país. Finalmente, os sistemas nacionais de inovação se referem a configurações de instituições que promovam o desenvolvimento de tecnologia e inovação (Nelson \& Rosenberg, 1993). Um princípio central documentado por esta literatura é que os países diferem em sua capacidade de produzir conhecimento, e na medida em que pode aproveitar esse conhecimento ao ser conectado a outros países (Furman, Porter, \& Stern, 2002; Porter, 1990).

Usando a abordagem de Mahalanobis para abordar a questão das relativamente altas correlações entre as variáveis indicadoras e as diferentes escalas em que são medidas, Berry et al. (2010) identificaram nove dimensões de distância: econômica, financeira, política, administrativa, cultural, demográfica, conhecimento, conectividade e geográfica. Os modelos foram empiricamente testados em quatro contextos gerenciais experimentados por empresas multinacionais americanas: as decisões de entrada inicial e sequenciais de empresas; a escolha de produção contra subsidiárias de distribuição; a escolha entre países de acolhimento de renda alta e baixa; e as escolhas de mercados estrangeiros por empresas de alto versus baixo investimento em pesquisa e desenvolvimento.

Uma característica importante da abordagem de Berry et al. (2010) é que eles realizaram o cálculo das distâncias para cada dimensão separadamente, permitindo, assim, aos 
investigadores, utilizarem aquele que melhor se adapta teoricamente à sua pergunta de pesquisa.

Os autores descobriram que: a) a distância cultural (combinando as dimensões do Hofstede quer por métodos euclidianos e de Mahalanobis) desencoraja as empresas de investir no exterior, b) variáveis de cultura em conjunto com outras dimensões de distância têm efeitos diferenciais sobre a propensão das empresas para investir em mercados estrangeiros, c) essas diferenças na propensão são específicas ao contexto. Estas descobertas tornam explícitas as limitações do uso de uma variável distância que se baseia exclusivamente em uma dimensão cultural, e sublinham a importância de se considerar múltiplas dimensões de distância quando se analisa a influência das distâncias transfronteiriças em toda uma gama de decisão empresariais (Berry et al., 2010).

\subsection{Políticas Públicas de Suporte a Exportação e Internacionalização}

Até meados do século XX, os governos participavam dos negócios internacionais quase que exclusivamente por meio de políticas públicas de promoção das exportações, que se apoiavam nas vantagens comparativas ricardianas (Coelho, 2014). Os governos estavam restritos a políticas comerciais e industriais, cujo objetivo era incentivar a estrutura de produção e produtividade de suas economias, buscando uma melhoria do bem-estar social. Contudo, esse tipo de política comercial privilegiava a exportação como forma de inserção internacional. Assim, as empresas mantinham suas atividades de valor e produção no país (Coelho \& Oliveira Junior, 2016).

A partir do final do século $\mathrm{XX}$, muitos governos perceberam que auxiliar a competitividade internacional das empresas em seu território, leva ao fortalecimento do próprio poder nacional (Porter, 1989; Castells, 1999; Krugman, 1996; Dunning, 2003; Dicken, 2010).

Alem e Cavalcanti (2005) argumentam que a internacionalização pode levar a um crescimento do número de empregos na economia de origem, o que certamente poderia deixar de acontecer caso uma empresa não internacionalizada e enfraquecida pela concorrência internacional com outras transnacionais viesse a fechar as suas portas. Segundo Ricupero e Barreto (2007), um exemplo disso é o que aconteceu com firmas brasileiras de autopeças, de eletrônica e de telecomunicações que foram adquiridas para serem fechadas ou convertidas em escritórios de importação e oficinas de montagem de insumos importados. A consequência 
disso não foi apenas a perda de empregos, mas, principalmente, "a perda irreparável de centros de pesquisa e de desenvolvimento de tecnologia brasileira autônoma" (Ricupero \& Barreto, 2007: 24).

A literatura teórica e a experiência das firmas indicam que dependendo das características dos produtos, bem como do mercado receptor e do tipo de investimento realizado, o investimento no exterior pode ser importante também para aumentar o volume exportado no país de origem. Por exemplo, os investimentos que têm como objetivo aumentar o espaço no mercado externo ou aumentar a produtividade da firma tendem a incrementar as exportações e a eficiência da firma investidora (Iglesias \& Veiga, 2002). Contudo, investimentos feitos para obter insumos melhores e de forma mais econômica, normalmente não têm um impacto direto sobre as exportações da firma investidora e do país emissor, podendo contribuir para o aumento das importações. Já o investimento direto para produção no exterior também pode ter um efeito negativo sobre as exportações, na medida em que substitui exportações por produção no mercado de destino (Unctad, 1996).

Entretanto, é importante ressaltar que os impactos do investimento no exterior não se restringem a exportação. Ao substituir exportações, normalmente, as filiais geram demanda por outros produtos de bens intermediários e serviços, que acabam sendo oferecidos por empresas parceiras do país de origem (Unctad, 1996). Somente através da análise de todos os efeitos indiretos seria possível definir o impacto total do IDE sobre o comércio externo do país. Segundo estudo da Unctad (1996), frequentemente, a substituição da exportação devido à produção em outro país leva a um aumento da exportação de suporte comercial, além de proporcionar novas comercializações. Em países desenvolvidos, há claras evidências de que o investimento direto no exterior tem efeitos positivos nos países de origem, o que foi comprovado através de uma série de estudos realizados com empresas transnacionais nos Estados Unidos (Unctad, 1996: 80):

i. No que se refere à relação entre as exportações dos Estados Unidos e os IDEs em indústrias manufatureiras, um estudo encontrou uma correlação positiva entre a expansão dos investimentos diretos no exterior e a exportação americana, com forte associação que, entretanto, decresce com o aumento do IDE (Bergsten; Horst \& Moran, 1978 apud Unctad, 1996). A conclusão de Bergsten foi que nos estágios iniciais de investimento direto no exterior, as filiais estrangeiras são altamente dependentes das exportações das matrizes de produtos intermediários e finais, contudo, com a expansão das operações locais, a dependência reduz. 
ii. Outro estudo encontrou que o nível de produção das filiais das empresas americanas nos países em que expandiram apresenta um impacto favorável na exportação da indústria daquele país (Lipsey \& Weiss, 1981 apud Unctad, 1996). Contudo, a produção externa das filiais americanas impacta negativamente na exportação dos mesmos produtos no país de origem.

iii. Pesquisa baseada em cross-section de transnacionais americanas na década de 1970 identificou que havia uma correlação positiva entre as saídas de investimento direto no exterior (medidos em termos da produção das filiais estrangeiras) e o valor da exportação de manufaturados de firmas complementares, isso em todas as regiões americanas, bem como nas indústrias pesquisadas (Lipsey \& Weiss, 1984 apud Unctad, 1996). O aumento das exportações da produção das filiais no exterior não apresenta relação com a redução da exportação da empresa, no país de origem para outros países. Por outro lado, observou-se um alto impacto positivo no aumento da exportação das empresas matrizes no que tange produtos intermediários e finais.

iv. Estudos realizados com transnacionais suecas apresentaram positiva correlação entre a produção das filiais estrangeiras e a exportação das empresas nos países emissores (Swedenborg, 1979,1985 apud Unctad, 1996).

v. Estudo realizado em 1982 sobre a produção das filiais estrangeiras e a exportação das maiores indústrias mundiais encontrou uma correlação positiva entre as duas variáveis (Pearce, 1990 apud Unctad, 1996). Esse estudo mostrou que o investimento direto no exterior estava mais positivamente ligado à exportação no grupo da empresa do que entre diferentes companhias.

Os diversos estudos sobre o efeito dos fluxos de investimento direto no exterior indicam que há evidências que tanto o volume de exportação quanto o volume de importação aumentam com o fluxo de IDE, porém, sua composição se altera, aumentando o volume de peças e bens intermediários e diminuindo o volume de produtos finais (Lipsey; Weiss, 1984; Pearce, 1990 apud Unctad, 1996), uma vez que uma das principais razões para a realização do IDE de empresas em outros países é que elas consigam produzir determinado bem em outros locais com maiores vantagens comparativas.

Assim, não se deve analisar apenas o impacto na balança comercial do país para chegar às conclusões de vantagens ou desvantagens do investimento no exterior para o país emissor. 
Diante de tais fatos, inúmeros países passaram a incorporar a dinâmica da competição internacional através de políticas direcionadas à internacionalização das empresas (Porter; 1986).

Neste contexto, os governos assumiram papéis mais ativos nos processos de desenvolvimento de suas economias, ultrapassando a questão das políticas macroeconômicas de estabilização e abordando, também, políticas de impactos estruturais, voltadas a uma estratégia de desenvolvimento (Castells, 1999; Bresser-Pereira, 2006). Assim, os governos, buscando um fortalecimento da competitividade internacional de suas empresas, passaram a abordar, também, políticas de estimulo ao investimento direto estrangeiro (IDE) em ambas as direções (Sauvant, et.al., 2014).

Com isso, as políticas públicas de apoio à internacionalização devem englobar tanto vantagens comparativas com base em produtividade, quanto incorporar aspectos das determinantes microeconômicas e estratégicas das empresas, desde as suas motivações e características até as suas vantagens de propriedade e outros fatores comportamentais (Penrose, 1956; 2006; Hymer, 1976; 1983; Vernon, 1966; 1979; Buckley, Casson, 2002; Dunning, 1980, 1988, 2001; Johanson; Vahlne, 1977; 1990).

É visão amplamente sustentada, apoiada pela literatura, que IDE traz uma contribuição positiva para a economia de um país anfitrião, introduzindo um conjunto de recursos tangíveis e intangíveis: capital, tecnologia, habilidades, técnicas de gestão, marcas e acesso aos mercados, entre outros. No entanto, a atração de IDE não garante que todos os benefícios que ela carrega possam ser colhidos pelos países anfitriões. Faz-se necessário que haja políticas locais que garantam as ligações com a economia doméstica, regras de concorrência adequadas com as empresas nacionais, entre outras coisas, o que reforça a atenção significativa dada às políticas para atrair, reter e maximizar os benefícios potenciais de IDE.

Por outro lado, a ambiguidade dos efeitos líquidos no país de origem das firmas gera grande dificuldade para definir a conveniência ou não de ter políticas públicas que estimulem o investimento das empresas domésticas no exterior (Iglesias \& Veiga, 2002). Um questionamento frequente, nos países em desenvolvimento, se confronta com o problema da melhor utilização de um recurso relativamente escasso, como são as divisas externas (Unctad, 1995). Alem e Cavalcanti (2005) apresentam, ainda, a dúvida se é desejável que um país em desenvolvimento que está absorvendo recursos externos estimule a saída de capitais no conceito de investimento no exterior, bem como, o fato de o investimento no exterior reduzir as exportações líquidas do país emissor, ao substituir exportações por produção no mercado 
externo, o que pode agravar mais ainda os problemas do financiamento do balanço de pagamentos.

Contudo, segundo Iglesias e Veiga (2002), o contra-argumento utilizado é que, para empresas que competem em forma globalizada e que enfrentam transformações no plano tecnológico e produtivo, a internacionalização via investimento externo pode ser a única alternativa, uma vez que o investimento externo é vitalmente necessário para poder continuar competindo nos mercados externos e desenvolvendo a linha de produtos da firma.

De acordo com John Stopford, professor da London Business School e do projeto Global Players da Fundação Dom Cabral, as empresas locais devem, se não por outras razões, para ao menos garantir a sua participação de mercado, aprender a competir no mesmo nível das empresas mais eficientes do mundo, o que tem mais chance de ocorrer com os ganhos de competitividade decorrentes da internacionalização. É importante ter a percepção de que se mantendo apenas no mercado doméstico, as empresas não desenvolvem os conhecimentos necessários para competirem no mercado internacional.

Quando uma empresa intensifica seu processo de internacionalização, aumenta a capacidade de competir com concorrentes transnacionais, tanto no mercado global, quanto em seu mercado de origem. Sauvant (2007: 62) reforça que "os governos de países emergentes precisam se conscientizar da importância da saída de IDEs para a competitividade das suas empresas". Segundo ele,

"Hoje as empresas já não conseguem mais se refugiar no abrigo seguro dos seus mercados domésticos, como fonte relativamente certa de lucro. A concorrência das empresas estrangeiras está em todo lugar. Ela se manifesta através de importações, da entrada de investimentos de formas não acionárias de participação, etc.” (SAUVANT, 2007: 62).

A liberalização e a globalização da economia mundial resultam que para uma firma ser competitiva, e melhorar o desempenho do seu país de origem, ela deve ser capaz de compreender e se adaptar aos desafios globais (Unctad, 1995). Assim, não realizar investimentos no exterior pode acarretar perda de dinamismo das empresas nacionais devido à pressão da concorrência internacional, ocasionando impactos negativos sobre o emprego e a competitividade da economia.

Pesquisa realizada por Salerno e De Negri (2005) confirma que a escala de produção das firmas brasileiras com investimento direto no exterior é significativamente superior à daquelas que não investem no exterior. Arbix, Salerno e De Negri (2004), por sua vez, testando, através de um modelo econométrico, os fatores explicativos da probabilidade de a firma industrial brasileira realizar investimentos no exterior, concluíram que "a inovação 
tecnológica de produto novo para o mercado é positiva e fortemente correlacionada com a condição de as firmas industriais brasileiras realizarem IDE".

Para Travesso Neto (2007: 139), “à medida que mais empresas se internacionalizam, o processo evolui e traz melhorias ao país e aos brasileiros". Além da ampliação de mercado, as “multinacionais" brasileiras geram conhecimento, tecnologia e novos processos, contribuindo para um melhor posicionamento estratégico, melhorando os fornecedores - com exigências de padrão global - e, obviamente, transferindo isso tudo para o mercado local, ou seja, para a sociedade brasileira.

Prochnik, Esteves e Freitas (2006) comprovaram através de suas pesquisas que as empresas industriais de capital brasileiro que realizam IDE têm produtividade muito mais elevada que as congêneres que somente exportam. Por sua vez, a produtividade destas últimas é significativamente maior que a daquelas que não exportam nem investem. Os autores concluem que "a estratégia de inovação, a política de recursos humanos das empresas e o seu porte e produtividade são dimensões relevantes para explicar o grau de internacionalização das firmas brasileiras" (Prochnik; Esteves \& Freitas, 2006: 342) e ressaltam que a variável mais importante é o percentual de pessoas ocupadas em pesquisa e desenvolvimento.

A internacionalização de empresas representa, na verdade, uma importante oportunidade de acesso ao conhecimento e a recursos que repercutem favoravelmente em suas comunidades de origem. Permite que a empresa absorva novas tecnologias, obtenha recursos financeiros mais facilmente e a menores custos, aprimore sua capacidade gerencial e acesse informações de mercado mais preciosas e profundas, possibilitando um aumento de eficiência de atuação naquele mercado. Isso tudo, não aumenta apenas a capacidade competitiva da empresa, mas sim do país como um todo (Almeida, 2007).

O resultado de todas essas pesquisas realizadas torna evidente a importância de que os governos utilizem políticas para estimular suas empresas a expandirem para o mercado internacional, melhorando, com isso, não apenas a competitividade empresarial, mas também, a competitividade nacional.

De acordo com a Unctad (2006), não há uma fórmula ou padrão de política pública de internacionalização que seja um modelo a ser adotado por todos os países. Elas são concebidas a partir das condições específicas de desenvolvimento e estratégia nacional de cada país.

As políticas de promoção à internacionalização surgem como formas de reduzir as imperfeições, assimetrias e barreiras existentes nos mercados, que restringem as possibilidades de inserção externa das empresas (IPEA, 2012). As políticas de 
internacionalização podem ser compreendidas de duas maneiras distintas (Sennes \& Mendes, 2009): (i) a primeira tem caráter mais amplo e engloba todas as iniciativas que agem de forma direta ou indireta para impactar positivamente a internacionalização das empresas, como políticas de inovação pró-tecnologia, apoio a reformas regulatórias específicas, políticas voltadas para a promoção de ganhos de eficiência nas empresas nacionais em segmentos específicos; e (ii) a segunda refere-se a políticas mais restritivas, que impactam de forma direta e explícita as decisões das empresas sobre projetos de investimento, parcerias, concorrência ou aquisições no exterior. Nesse caso, o enfoque não está num maior ganho competitivo, mas sim na alteração das condições regionais da empresa para concorrer em situações específicas que atendem às particularidades dos concorrentes de outros mercados e regiões.

É importante distinguir as políticas de promoção de outras medidas que afetam os fluxos de investimento. Esse instrumento deve ir além de permitir, simplesmente, a liberalização da saída de IDE (que é uma condição necessária, mas não suficiente para que as empresas de um país de origem possam se envolver em IDE), ou mesmo ter uma política neutra (Economou \& Sauvant, 2013). Em vez disso, é necessário que as ações governamentais facilitem, apoie ou mesmo promova tal investimento, através de instrumentos como o fornecimento de informações, de seguro de risco político, da celebração de acordos bilaterais de investimentos e de dupla tributação, benefícios financeiros ou fiscais, ou ainda ajuda direta para empreender no exterior (Sauvant, et.al., 2014).

Como podem ser observadas na Figura 6, essas medidas não são novas, sendo que políticas de incentivos para facilitar o IDE no exterior foram introduzidas na década de 1950 e 1960 pelos Estados Unidos, Reino Unido, Japão, Alemanha, França e, na década de 1970, na maioria dos outros países desenvolvidos.

A partir dos anos 1980, houve o compartilhamento da ideia comum que os governos podem, e devem ter papel importante no estímulo aos negócios internacionais, o que deve ocorrer por meio de políticas de promoção às exportações que incluam programas de assistência e suporte que incluam elementos como (Unctad, 2004, 1995; Lewis, 1990): i) liberalização das restrições aos investimentos diretos no exterior - tendo em vista que implicam saída de divisas (isso foi particularmente relevante no caso de países em desenvolvimento e nas economias em transição); ii) criação de instrumentos internacionais que facilitem e protejam os investimentos no exterior; iii) informação e assistência técnica; iv) incentivos fiscais; v) mecanismos de seguros para os investimentos; e vi) financiamento. 


\begin{tabular}{|c|c|c|c|c|c|c|}
\hline & \multicolumn{4}{|c|}{ Informação e assistência técnica } & \multirow[b]{2}{*}{ Financiamento } & \multirow{2}{*}{$\begin{array}{l}\text { Seguros e } \\
\text { Garantias }\end{array}$} \\
\hline & Informações & Missões & $\begin{array}{l}\text { Análise de } \\
\text { viabilidade }\end{array}$ & $\begin{array}{l}\text { Desenv. do } \\
\text { Projeto }\end{array}$ & & \\
\hline Austrália & $\mathrm{X}$ & $\mathrm{X}$ & $\mathrm{X}$ & & & \\
\hline Áustria & $\mathrm{X}$ & & & & $\mathrm{X}$ & $\mathrm{X}$ \\
\hline Bélgica & $\mathrm{X}$ & & & & $X$ & $X$ \\
\hline Canadá & $\mathrm{X}$ & $\mathrm{X}$ & $\mathrm{X}$ & $\mathrm{X}$ & $X$ & \\
\hline Dinamarca & & & & & $\mathrm{X}$ & \\
\hline Finlândia & $\mathrm{X}$ & $\mathrm{X}$ & $\mathrm{X}$ & $\mathrm{X}$ & $\mathrm{X}$ & $\mathrm{X}$ \\
\hline França & $\mathrm{X}$ & & $\mathrm{X}$ & $\mathrm{X}$ & $\mathrm{X}$ & \\
\hline Alemanha & $\mathrm{X}$ & $\mathrm{X}$ & $\mathrm{X}$ & $\mathrm{X}$ & $\mathrm{X}$ & $\mathrm{X}$ \\
\hline Itália & $\mathrm{X}$ & $\mathrm{X}$ & $\mathrm{X}$ & $\mathrm{X}$ & $\mathrm{X}$ & $\mathrm{X}$ \\
\hline Japão & $\mathrm{X}$ & $X$ & $\mathrm{X}$ & $\mathrm{X}$ & $X$ & $X$ \\
\hline Países Baixos & $\mathrm{X}$ & $X$ & $\mathrm{X}$ & & $X$ & $X$ \\
\hline Nova Zelândia & $\mathrm{X}$ & & $\mathrm{X}$ & $\mathrm{X}$ & & \\
\hline Noruega & $\mathrm{X}$ & $\mathrm{X}$ & $\mathrm{X}$ & $\mathrm{X}$ & $\mathrm{X}$ & $\mathrm{X}$ \\
\hline Portugal & $\mathrm{X}$ & $X$ & & & $X$ & \\
\hline Espanha & $X$ & $X$ & & & $X$ & $\mathrm{X}$ \\
\hline Suécia & $\mathrm{X}$ & & $\mathrm{X}$ & $\mathrm{X}$ & & \\
\hline Suíça & $X$ & $X$ & $\mathrm{X}$ & $X$ & $X$ & $X$ \\
\hline Reino Unido & & & & $X$ & $X$ & \\
\hline Estados Unidos & $\mathrm{X}$ & $\mathrm{X}$ & $\mathrm{X}$ & $\mathrm{X}$ & $\mathrm{X}$ & $\mathrm{X}$ \\
\hline
\end{tabular}

Figura 6 - Instrumentos de apoio ao investimento direto no exterior (países desenvolvidos), início da década de 1990.

Fonte: Unctad (1996, p. 196)

Nos anos mais recentes, um número crescente de países em desenvolvimento tem iniciado políticas de incentivo à internacionalização de empresas nacionais, o que tem gerado o crescimento do número de multinacionais com origem nestes países (Unctad, 1995).

No aspecto metodológico, todas as políticas públicas de fomento ao processo de internacionalização descritas neste estudo seguem um padrão de classificação baseado no IPEA (2012) e Unctad (2006) conforme a Figura 7.

A utilização dessa classificação serve para separar as políticas específicas (que refletem a preocupação dos governos com a internacionalização) das políticas gerais que influenciam a realização de investimentos diretos no exterior (capacitação de recursos humanos, produção de ciência e tecnologia, estabilidade política, infraestrutura, entre outras) (Unctad, 2006).

De acordo com a Unctad (2006), existem duas vertentes sobre os processos de promoção à internacionalização das empresas. A primeira defende que as políticas públicas devem ser mais específicas e voltadas para grupos específicos, os chamados "picking winners", ou seja, os de maior importância estratégica, que desenvolvem vantagens tecnológicas e de inovação, bem como para a promoção de aglomerados industriais e arranjos 
produtivos locais em desenvolvimento e com alto potencial econômico. Essa seletividade permite o alcance de objetivos sócio-políticos para a promoção de uma ação afirmativa para esses diferenciais competitivos.

\begin{tabular}{|c|c|}
\hline Classificação & Políticas Públicas \\
\hline $\begin{array}{l}\text { Apoio informacional, } \\
\text { assistência técnica e } \\
\text { outras orientações }\end{array}$ & $\begin{array}{l}\text { Compreende todos os mecanismos e instrumentos governamentais } \\
\text { direcionados a propiciar suporte informacional e por vezes experiencial às } \\
\text { empresas em processo de internacionalização, cujos objetivos primários estão } \\
\text { direcionados às reduções de assimetrias de informação e de custos de } \\
\text { transação. Disponibilização de publicações, base de dados, facilitação de } \\
\text { contatos, promoção de seminários, organização de missões oficiais; } \\
\text { treinamento, serviços técnicos - como assistência legal, consultorias, estudos } \\
\text { de viabilidade. }\end{array}$ \\
\hline Criação de comfort zone & $\begin{array}{l}\text { Compreende as ações voltadas a criar, nos países de destinos, instituições nas } \\
\text { quais seja possível se criar e desenvolver serviços e redes de contato capazes } \\
\text { de propiciar à empresa demandante uma chegada facilitada e apoiada ao seu } \\
\text { destino. Criação no país de destino do investimento de um one stop point, } \\
\text { onde é possível o acesso facilitado a vários serviços num mesmo lugar. }\end{array}$ \\
\hline $\begin{array}{l}\text { Instrumentos fiscais e } \\
\text { tributários }\end{array}$ & $\begin{array}{l}\text { Compreende todos os incentivos fiscais e tributários promovidos pelos órgãos } \\
\text { governamentais, sejam de isenções, suspensões, reduções ou restituições. } \\
\text { Visam à redução do custo dos projetos de investimentos no exterior, por meio } \\
\text { de incentivos fiscais e isenções tarifárias. }\end{array}$ \\
\hline $\begin{array}{l}\text { Mecanismos de segurança } \\
\text { de investimento e } \\
\text { minimização de riscos }\end{array}$ & $\begin{array}{l}\text { Compreende todas as garantias de cobertura e seguro direcionadas a reduzir } \\
\text { riscos associados a restrições de transferência de moedas, expropriações, } \\
\text { guerras e demais situações de instabilidade econômicas e políticas. }\end{array}$ \\
\hline $\begin{array}{l}\text { Ampliação dos } \\
\text { mecanismos e das } \\
\text { modalidades de } \\
\text { financiamento }\end{array}$ & $\begin{array}{l}\text { Compreende os incentivos creditícios disponibilizados pelos governos às suas } \\
\text { empresas, destacadamente as linhas de financiamentos específicas à } \\
\text { internacionalização, empréstimos preferenciais, equity e créditos de } \\
\text { exportações. }\end{array}$ \\
\hline $\begin{array}{l}\text { Celebração de acordos } \\
\text { internacionais de } \\
\text { investimentos e tributação }\end{array}$ & $\begin{array}{l}\text { Celebração de acordos por parte dos Estados, envolvendo países considerados } \\
\text { prioritários para investir - geralmente tratados de proteção jurídica dos } \\
\text { investimentos e eliminação da bitributação. }\end{array}$ \\
\hline
\end{tabular}

Figura 7 - Padrão de classificação para as políticas públicas de fomento ao processo de internacionalização

Fonte: Elaboração própria baseado em informações do Ipea (2012) e Unctad (2006)

Por outro lado, enquanto a perspectiva acima descrita enfatiza que os investidores devem se comportar escolhendo setores estratégicos da economia, a outra vertente, com uma perspectiva mais restritiva implica em políticas "severas", como a reserva de mercado para uma parcela de empresas, como as micro e pequenas empresas, as empresas estatais e as empresas de determinados grupos étnicos, bem como a imposição de exigências para investidores estrangeiros com o objetivo de estabelecer equidade nacional, acordos de partilha de tecnologia ou metas obrigatórias de exportação, relativas ao comércio e a medidas de investimento (Unctad, 2006). 
Igualmente, Kray (2006), Hoekman e Javorcik (2006) e Harris e Cher Li (2005), complementam as perspectivas de políticas públicas da Unctad (2006), ao apresentar a primeira como mais ampla e que envolve todas as iniciativas que agem de forma direta ou indireta para impactar positivamente a internacionalização das empresas, como políticas de inovação pró-tecnologia e apoio a reformas regulatórias específicas no mercado de capitais que e tornariam o mercado mais atraente frente a seus concorrentes regionais. Já a segunda refere-se a políticas mais restritivas, que impactam de forma direta e explícita as decisões das empresas sobre projetos de investimento, parcerias, concorrência ou aquisições no exterior.

Enquanto na primeira abordagem as políticas são focadas mais em possibilitar que as empresas concorram no mercado internacional de forma mais ampla e homogênea, na segunda há a promoção de ações governamentais variáveis, dependendo do setor, região e país.

Neste contexto, observou-se o surgimento de agências de promoção de exportações e investimentos, as quais se tornaram protagonistas na realização e condução deste tipo de política. Devido às características existenciais de atuar diretamente no fornecimento de conhecimento sobre mercados, essas organizações acabaram por se destacar como os principais agentes de políticas governamentais de promoção das exportações em detrimento de outros programas, tornando-se, nesse sentido, fundamental a análise de suas estratégias de atuação (Coelho, 2014). Nos anos mais recentes, essas agências se tornaram também instrumentos fundamentais para a atração de investimentos e estímulos de internacionalização de empresas nacionais.

\subsection{O Papel das Agências de Promoção à Exportação e ao Investimento (APEI)}

Como salientado por diversos autores (Ricupero, 2007; Porter, 1989; Fleury \& Fleury, 2007), em um mundo globalizado, vantagens competitivas podem estar além das fronteiras de uma nação. Assim, é fundamental a projeção internacional das empresas de um país. Considerando que no mercado real os custos de transação não são nulos, o surgimento da empresa será justificado quando o processo de coordenação da atividade internamente for mais produtivo do que deixá-la atuando isoladamente no mercado. Para Coase (1937), a economia é basicamente orientada pelo mercado e as empresas só surgem quando a coordenação gerencial se mostra superior ao mercado. 
O processo de internacionalização das empresas pode ser compreendido por meio deste contexto. Ideias de Coase, Buckley e Casson (2009) consideram que a existência de mercados imperfeitos gera benefícios de se internalizar a produção, levando ao surgimento de empresas transnacionais. Analisando-se sob esta perspectiva, não apenas os mercados consumidores finais são os motivadores para a internacionalização das empresas, mas também os mercados intermediários, uma vez que os processos produtivo e comercial no ambiente internacional podem proporcionar vantagens em termos de tecnologia, patente, capital humano, etc.

No lado da empresa, mais que a exportação, o IDE é uma estratégia empresarial intrinsecamente arriscada. Ela envolve grandes investimentos, como os relativos aos custos de aquisição de informação para superar a falta de conhecimento e familiaridade com o mercado local.

As especificidades do mercado de destino, destacadamente com suas assimetrias de informações das mais diversas ordens e riscos institucionais existentes, têm compelido os governos a optarem por estabelecer, no âmbito de suas políticas de internacionalização, agências de promoção de exportações e investimentos como estratégia para vários países (Coelho \& Oliveira Junior, 2016). Essas agências são consideradas instituições-chave na indução da inserção internacional de empresas nacionais, consequentemente do aumento da prosperidade e bem-estar de um país.

Ao disponibilizar informações de mercado, auxiliar os investidores na busca por parceiros, prestar serviços e divulgar informações sobre o país, coordenar atividades que melhorem o ambiente de negócios, as agências de promoção à exportação e ao investimento reduzem a incerteza do mercado, e o risco ao comportamento oportunista das empresas no exterior.

Neste contexto, o surgimento das APEI resulta dos esforços por parte do governo em mitigar os elevados riscos em mercados internacionais e promover um aumento da competitividade das empresas nacionais, via exportações e investimentos no exterior, além de buscar atrair o investimento estrangeiro (Hayakawa et al., 2014). As APEIs têm objetivos de fornecer serviços de apoio à exportação, tais como programa ou informações sobre o financiamento do comércio formação exportador e para coincidir com potencial exportador e importador, além de promover a saída de IDE (Hayakawa et al., 2011; Hayakawa et al., 2014).

As atividades das APEIs governamentais e semigovernamentais podem ser justificadas por determinadas falhas de mercado (Hayakawa et al., 2011). Portanto, se APEIs 
governamentais são capazes de fornecer informações sobre mercados estrangeiros para as empresas nacionais, eles podem agir como um catalisador para o aumento das exportações (Hayakawa et al., 2011).

As APEIs e suas operações podem servir como espelho aos governos, refletindo o estado de prática da política, pois, políticas de promoção de exportações e fluxos de IDE devem ser vistos como os dois lados de uma mesma moeda. São indissociáveis e a promoção não é nada mais do que a execução de uma parte fundamental das políticas dos governos, que são, muitas vezes, mais fácil de serem articuladas do que colocadas em prática.

Wells e Wint (2001, p. 4) definem a promoção do investimento como "atividades que divulgam informações sobre, ou tentar criar uma imagem do site de investimentos e prestar serviços de investimento para os investidores potenciais". Esta definição engloba as duas justificaçõess analíticas mais importantes para APEIs. A primeira justificativa é o seu papel na comunicação e divulgação de informações. De fato, as empresas locais podem voluntariamente restringir os fluxos de informação para evitar a entrada de novos concorrentes potenciais. Campanhas de promoção constituem um mecanismo importante para comunicar todas as características que tornam um país de acolhimento atraente para os investidores, incluindo as políticas existentes e iniciativas de reforma recentes. Já a segunda justificativa é que as APEIs podem desempenhar um papel na coordenação da maioria das atividades destinadas a melhorar o ambiente de negócios no país de acolhimento. Esse papel pode variar de prestação de assistência a potenciais investidores em seus problemas diários, como realização de lobby para a política chave e reformas legais. Em muitos países, a APEI é vista como uma interface entre os setores públicos e privado (Morisset \& Andrews-Johnson, 2004).

Apesar da complexidade do processo que envolve os fluxos de comércio entre os países, estruturas diversificadas de APEIs com sistemas de apoio diferenciados têm prestado contribuição significativa ao desenvolvimento de suas economias. Pequenas, médias e grandes empresas privadas ou públicas têm se beneficiado de inúmeros tipos de apoios disponibilizados por essas agências de países em diferentes fases de desenvolvimento econômico e com estruturas produtivas variadas.

Conforme salientado anteriormente, muitos governos vêem nas APEIs um instrumento nas estratégias para o desenvolvimento dos respectivos países. Esse modelo de agência foi inicialmente concebido para ser exclusivamente de promoção da inserção comercial, via exportações, no que era denominado TPO - trade promotion organization (Coelho \& Oliveira Junior, 2016). Conforme Jaramillo (1992), suas atividades eram agrupadas em quatro 
dimensões: i) identificação e desenvolvimento de produtos e mercado; ii) serviços de informação sobre comércio; iii) assistência especializada; e iv) atividades promocionais no exterior. A atuação era principalmente no mercado interno do país de origem da agência, onde esta buscava identificar potenciais produtos e mercados, capacitar e induzir as empresas nacionais à exportação (Lederman; Olarreaga, \&Payton, 2006; Jaramillo, 1992; Coelho \& Oliveira Junior, 2016).

Contudo, não obstante os esforços de promoção das exportações, as agências têm ampliado o seu escopo de atuação, empenhando-se em várias frentes, destacadamente aquelas que incluem formas mais avançadas de inserção internacional, como os IDEs, e atividades e serviços de apoio mais complexos e baseados nos mercados externos (Morisset, 2003). Assim, além da formação de uma base nacional de identificação de empresas e produtos potenciais, passaram a se estabelecer nos mercados estratégicos de destino, oferecendo novos serviços que facilitam a inserção das empresas nacionais nesses países.

Diante desse novo modelo, as agências alteram as suas estratégias de atuação, ampliando o apoio à internacionalização comercial, para a inserção produtiva e operacional, via investimento direto e contratos com empresas locais. Dessa maneira, novo portfólio de serviços é ofertado, o que passa a ser seguido de novas ações, as quais, em grande parte das vezes, são realizadas nos mercados de destino e a partir deles. Assim, essas agências passam a atuar nos mercados estrangeiros, adquirindo status de grandes facilitadoras de inserção, uma vez que constituem redes (networks) capazes de mobilizar tanto agentes privados quanto públicos de várias esferas e competências (Coelho, 2014).

De forma mais especifica, as agências de promoção de exportação e investimento (APEI) desenvolvem uma ampla e diversificada gama de atividades para estimular a internacionalização das empresas de um país. Segundo o International Trade Center (2000), tais atividades podem ser definidas em termos de externas (programas de desenvolvimento de mercados); internas (desenvolvimento de capacitação) e de desenvolvimento nacional. A escolha das atividades depende de seu planejamento estratégico, escopo, disponibilidade de recursos, demanda do público alvo, natureza e diversificação da oferta exportável e características dos mercados alvo.

De acordo com Hibbert (1989), as APEIs devem atuar também no suporte ao governo em todos os assuntos relativos à promoção de exportações, o que envolve o aconselhamento e suporte técnico às empresas e empresários; a promoção e desenvolvendo das exportações, suporte às empresas para o desenvolvimento de produtos voltados ao mercado externo, além de pesquisas relacionadas à sua área de atuação. Seringhaus e Botschen (1991) adicionam a 
essa lista a necessidade da APEI aconselhar o governo sobre redução de barreiras à exportação, bem como o desenvolvimento de incentivos ao exportador atual e potencial.

Além disso, os autores destacam que as agências devem auxiliar as empresas com potencial exportador possibilitando visibilidade a oportunidades de exportação, o acesso a conhecimentos sobre o processo de exportar, assistência para planejamento e preparação das atividades no mercado externo e apoio a iniciativas empresariais nos mercados estrangeiros.

Quanto à sua constituição, as APEIs podem ser puramente públicas, puramente privadas ou mistas (público e privadas) (ITC, 2000; Wells \& Wint, 2000). As organizações são consideradas mistas quando: parte de seu orçamento total é originário de recursos privados e parte de recursos públicos. Ou, quando tanto o setor público quanto o privado estão representados no alto escalão diretivo e administrativo da organização (Hibbert, 1989; ITC, 2000). Hibbert (1989) enfatiza que a APEI deveria possuir status administrativo e legal próprio, a fim de que seja reconhecida por outros órgãos governamentais como responsável pela coordenação de todos os esforços nacionais que visem expansão das exportações.

De acordo com o ITC (2000), uma organização de promoção de exportações bem sucedida apresenta quatro características: (1) a natureza da organização deve ser mista, garantindo o interesse do setor privado, (2) ser independente de autoridades políticas, garantindo continuidade, (3) ter mecanismos de financiamento exigindo participação do setor privado em parte do orçamento operacional, (4) que a estrutura salarial seja diferente daquela adotada pelo setor público, encorajando a retenção de talentos.

Entretanto, apesar dos países optarem por modelos diferentes de atuação e implantação, de operações e serviços dessas agências mundo afora, suas atividades podem ser geralmente apreendidas por uma divisão basicamente dada por duas macro áreas: promoção comercial e a atração de investimento (Morisset, 2003). E, de acordo com tal modus operandi, parte dos funcionários da agência ficaria responsável pelas informações sobre o mercado e outros serviços afins, como a indicação de contratação de serviços jurídicos e logísticos locais, para os exportadores, ou seja, a inserção comercial, e outra alocada na prospecção e auxílio aos empresários que pretendem se inserir pelos investimentos, fixando-se naquele mercado.

Diante dos desafios impostos pela promoção comercial e de investimentos nos mercados estrangeiros, diversos países optam por alocar o seu corpo diplomático como funcionários das agências; caso dos países que baseiam as suas agências nos Ministérios de Relações Exteriores. Já outros governos preferem contratar profissionais altamente 
qualificados do setor privado diante das competências específicas de cada serviço prestado (USAID, 2004).

Morisset (2003) propõe que as agências de promoção, principalmente as de investimentos, podem ser vistas como veículos para abordar questões de informação e coordenação que tendem a desaparecer ao longo do tempo, uma vez que haja efetividade e sucesso de seus fins, com investimentos e comércio feitos entre os países envolvidos.

Wells e Wint (2001, p.4) definem a promoção ao investimento como "atividades que divulgam informações sobre, ou tentam criar uma imagem do local de investimentos, bem como prestar serviços para os investidores em potencial." Baseados nesta definição, esses autores argumentam que as duas principais justificativas para a existência das APEIs são:

i. Comunicação e divulgação da informação: campanhas de promoção constituem um mecanismo importante para comunicar todas as características que tornam um país atraente para os investidores, incluindo as políticas, reformas recentes e iniciativas existentes;

ii. Coordenação das atividades que visam melhorar o ambiente de negócios no país de acolhimento: este papel pode variar de prestação de assistência aos investidores potenciais e existentes em seus problemas diários de lobby e reformas legais. Em muitos países, a APEI é vista como uma interface entre os setores públicos e privado.

O Figura 8 apresenta as quatro funções chaves exercidas pelas APEIs (WELLS; WINT, 2001).

Embora as APEIs tenham tradicionalmente sido uma ferramenta utilizada pelos países, muitas vezes é difícil de avaliar com precisão a eficácia da mesma. Mais precisamente, é difícil estabelecer se a presença de um escritório da APEI em um país de destino incentiva empresas do país de origem a exportarem ou investirem neste país. A principal fonte de dificuldade é o problema de endogeneidade. Ou seja, o governo do país de origem da APEI pode decidir pela criação de um escritório da APEI no país destino precisamente porque muitas empresas do país de origem estão investindo no país destino. Por outro lado, a decisão pode ser baseada na boa relação entre os países ou relativamente atraente clima de investimento no país destino (Hayakawa et al., 2014). 


\begin{tabular}{|c|l|}
\hline \multirow{2}{*}{ Construção de imagem } & $\begin{array}{l}\text { Publicidade dos meios financeiros } \\
\text { Participação em exposições de investimento } \\
\text { Publicidade na indústria ou setor de meios específicos } \\
\text { Realização de missões de investimento do país de origem para país de } \\
\text { acolhimento ou vice-versa } \\
\text { Realização de seminários sobre oportunidades de investimento }\end{array}$ \\
\hline $\begin{array}{c}\text { Prestação de serviços } \\
\text { aos investidores }\end{array}$ & $\begin{array}{l}\text { Prestação de serviços de aconselhamento de investimento } \\
\text { Acelerar o processamento dos pedidos e autorizações } \\
\text { Prestação de serviços de pós-investimento }\end{array}$ \\
\hline Geração de investimento & $\begin{array}{l}\text { Engajar-se em mala direta ou campanhas de telemarketing } \\
\text { Realização missões específicas por indústria ou setor econômico de investimento } \\
\text { do país de origem para país hospedeiro e vice-versa } \\
\text { Realização seminários com informações de setores específicos } \\
\text { Engajar-se em pesquisa específica para determinada empresa }\end{array}$ \\
\hline Defesa política & $\begin{array}{l}\text { Participar de forças-tarefa políticas } \\
\text { Desenvolvimento de atividades de lobbying } \\
\text { Elaboração de leis ou recomendações políticas } \\
\text { Relatórios de percepção dos investidores }\end{array}$ \\
\hline
\end{tabular}

Figura 8 - Principais funções exercidas pelas APEIs

Fonte: Wells e Wint (2001)

Uma série de estudos tem avaliado o papel das agências governamentais na promoção das atividades de negócios internacionais de empresas de seus países. A maioria dos estudos existentes com esse enfoque é sobre a promoção das exportações e IDE. Estudos de promoção das exportações, que incluem Alvarez e Crespi (2000), Gil-Pareja et al. (2008) e Martincus e Carballo (2008) encontraram um efeito positivo significativo de promoção das exportações sobre as exportações (Hayakawa et al., 2014). Em um estudo recente com base em dados de pesquisa que abrangem 103 países desenvolvidos e em desenvolvimento, Lederman et al. (2010) confirma as conclusões anteriores de agências de promoção de exportações exercendo um efeito positivo significativo sobre as exportações (Hayakawa et al., 2014). Eles destacam a importância dos serviços das APEIs para superar as barreiras comerciais estrangeiras e resolver problemas de informação assimétrica associados à exportação (Hayakawa et al., 2014). Estudos de promoção de IDE examinaram se os esforços dos governos dos países de acolhimento para atrair investidores estrangeiros para o país são eficazes ou não (Hayakawa et al., 2014).

Em geral, esses estudos, que incluem Charlton e Davis (2007) e Harding e Javorcik (2010), mostram um efeito positivo da promoção IDE no IDE do país. Em contraste com o grande e crescente número de estudos sobre exportação e promoção de IDE, quase não há estudos que analisam as importações e promoção de saída de IDE (Hayakawa et al., 2014). Isto é perfeitamente compreensível, porque a prioridade tradicional dos governos tem sido a 
de promover as exportações e entradas de IDE e eles só recentemente começaram a promover importações e saída de IDE (Hayakawa et al., 2014).

Morisset e Johnson (2004) realizaram um estudo transversal, no qual exploraram a relação entre o esforço de promoção do investimento e fluxos de IDE em 58 países durante o ano de 2001. A amostra foi diversificada em termos de região, nível de renda per capita, e a magnitude do esforço de promoção do investimento. Os pesquisadores coletaram dados sobre a quantidade de recursos de 58 agências de promoção dedicadas a determinadas atividades de promoção e sobre a organização e financiamento dessas agências. Assumiu-se que a causalidade do esforço de promoção para os fluxos de IDE, e descobriram que a promoção do investimento, junto com o clima de investimento, medida pelo Heritage Foundation e o nível de desenvolvimento em cada país, desempenha um papel significativo para explicar as variações fluxos de IDE entre países. Esta associação positiva foi encontrada somente quando o esforço de promoção foi medido pelo orçamento da APEI. Os autores calcularam a elasticidades: em média, um aumento de 10 por cento em despesas de promoção parece produzir um aumento de 2,5 por cento em IDE (Morisset \& Johnson, 2004). No entanto, o estudo mostra que os gastos abaixo de um determinado nível anual deram pouco ou nenhum retorno.

Harding e Javorcik (2007) também encontraram uma relação positiva entre a promoção do investimento e sucesso na atração de IDE. Uma pesquisa recente realizada pela Universidade de Oxford mostrou também que um dólar gasto na promoção do investimento aumenta os fluxos de IDE em 189 dólares (Harding \& Javorcik, 2011).

A razão da relação e um possível impacto da atividade APEI sobre o IDE pode ser encontrada na assimetria de informação que os investidores estrangeiros enfrentam ao entrar em um novo mercado. Como sugere o estudo de Morisset e Andrews-Johnson (2004), a promoção do investimento é mais eficaz nos países nos quais há maior presença de assimetrias de informações e procedimentos burocráticos mais complexos. Além disso, as agências são estruturadas de forma a priorizar atividades e a focalização de esforços em determinados setores da economia que apresentam uma relação direta com o resultado gerado. Isso reforça a argumentação que as APEIs atuam como redutores de custos de transação no processo de internacionalização das empresas.

Estudos empíricos mostram que as agências mais eficientes compartilham uma grande visibilidade e potencial de participação do setor privado relativamente forte, através da existência de um conselho de administração, que inclui representantes do setor privado e a participação do primeiro-ministro ou presidente do país (Morisset \& Andrews-Johnson, 
2004). Morisset e Andrews-Johnson (2004, p.49) também identificaram um conjunto de variáveis internas que justificam a estrutura institucional das APEI, sendo elas: idade da agência; regime jurídico (fundada por lei ou decreto); filiação institucional e as ligações com o governo (público, público-privado, autônomo, ou privado); articulação com o setor privado (contribuição financeira, a frequência de reuniões e insumos, o grau de representação do setor privado); arranjos de relatórios (placa, órgão do governo, primeiro-ministro ou presidente); presença de escritórios no exterior; número de mandatos encima de promoção do investimento estrangeiro (por exemplo, promoção de exportações, programas de privatização); características dos funcionários e política salarial (funcionário público, nível salarial em comparação com o setor privado, bônus e incentivos).

A pesquisa de Morisset Andrews-Johnson (2004) mostra ainda que apenas três características parecem ter efeitos significativos sobre a eficácia das APEIs em todos os países:

i. Os fluxos de investimento direto estrangeiro (IDE) são significativamente mais baixos em países onde a APEI faz parte de um ministério em vez de um organismo autónomo ou uma instituição público-privada.

ii. A eficácia das APEIs é reforçada quando a agência relata a um conselho fiscal que inclui representantes do setor privado. Quanto maior o número de membros privados, maior será a eficácia da APEI.

iii. Quando a agência reporta diretamente ao presidente de um país ou um primeiroministro e todos os outros fatores são iguais, encontram-se maiores fluxos de IDE.

Segundo Morisset e Andrews-Johnson (2004), o estudo permite que se conclua que a criação de uma agência de promoção traz benefícios na maioria dos países ao redor do mundo, sendo que quanto maior a visibilidade da APEI no país e a participação do setor privado na agência, maior será a eficiência da mesma, o que evidencia a importância das relações institucionais.

\subsection{APEX-Brasil}

A necessidade de ampliar as exportações de produtos brasileiros deu início à APEXBrasil em 21 de novembro de 1997, via Decreto $n^{\circ} 2.398$, no governo do presidente Fernando 
Henrique Cardoso. Entre 1997 e 2003, a agência funcionava como uma gerência especial do SEBRAE Nacional (Serviço Brasileiro de Apoio às Micro e Pequenas Empresas). Em 2003, o presidente Luiz Inácio Lula da Silva reestruturou o serviço, criando a Agência Brasileira de Promoção de Exportação e Investimentos (APEX-Brasil), por meio do Decreto Presidencial $\mathrm{n}^{\circ} 4.584 / 2003$, que ampliou o seu porte, orçamento, responsabilidade e escopo de ação a partir de 2007 (para investimentos diretos e relações contratuais, inclusive), tornando-a uma das principais protagonistas da internacionalização de empresas brasileiras. Assim, a ApexBrasil tornou-se uma agência do governo brasileiro, como um serviço social autônomo ligado ao Ministério do Desenvolvimento, Indústria e Comércio Exterior (MDIC).

A agência atende empresas de todos os portes, especialmente pequenas e médias, e em todos os estágios de maturidade exportadora. Sua atuação está focada na promoção dos produtos e serviços brasileiros no exterior e na atração de investimentos estrangeiros para setores estratégicos da economia brasileira (Coluchi, 2011).

A APEX-Brasil tem a missão de desenvolver a competitividade das empresas brasileiras, promovendo a internacionalização dos seus negócios e a atração de investimentos estrangeiros diretos. Desde a sua criação, a agência vem ampliando a promoção comercial, mediante de projetos setoriais, dos mais diversos segmentos da economia brasileira. A APEXBrasil atua intensamente na promoção da imagem do Brasil e de seus produtos e serviços no exterior, contribuindo para uma presença mais ampla e mais qualificada do Brasil, auxiliando as empresas com diluição de custos para sua presença externa, capacitando as mesmas para o mercado internacional e até mesmo auxiliando nas negociações.

Assim, através da execução de projetos com entidades de classe representativas de setores da indústria e serviços, a agência vem contribuindo para os resultados da balança comercial por meio da diversificação da pauta exportadora, abertura de novos mercados e consolidação e ampliação dos mercados tradicionais e de itens com maior valor agregado.

A APEX-Brasil trabalha com as seguintes diretrizes: identificar vocações produtivas regionais; fortalecer as entidades de classe; realizar estudos e prospecções de mercado; firmar acordos de cooperação com redes internacionais; realizar grandes eventos, tendo o Brasil como tema; inserir novas empresas no mercado internacional; promover encontros de negócios com importadores; executar/coordenar eventos internacionais (missões comerciais, feiras, encontros de negócios); promover a imagem do Brasil (Coluchi, 2011).

Para atingir seus objetivos, a APEX-Brasil criou a Unidade de Inteligência Comercial, responsável pelo desenvolvimento de estudos de mercado que identificam oportunidades para a comercialização dos produtos brasileiros em mercados estrangeiros. Com o intuito de apoiar 
empresas em estágios mais avançados de exportação, foi iniciada, em 2005, a implantação de Centros de Distribuição (CDs) em cidades ao redor do mundo (Miami, Frankfurt, Lisboa, Varsóvia e Dubai), incrementando o apoio logístico e administrativo oferecido aos exportadores brasileiros (Coluchi, 2011; Coelho, 2014). Por esse sistema, a APEX-Brasil alugava o espaço total, subloca partes desse espaço às empresas de pequeno e médio porte que já possuíssem cultura exportadora e obtinham ganhos de escala para essas empresas. $\mathrm{O}$ estabelecimento de centros de distribuição pela agência brasileira visava à implantação de uma estratégia para promover a internacionalização competitiva das empresas nacionais por meio da eliminação de intermediários comerciais. Buscava-se, assim, aproximar a produção nacional dos consumidores estrangeiros a partir do destino, permitindo preços mais competitivos. Dessa forma, os Centros de Distribuição se constituíram em espaços físicos de estocagem, pensados para facilitar a entrega dos produtos e proporcionar maior capacidade de resposta das empresas em atividades de pós-venda.

Contudo, entre 2007 e 2010, motivada, em grande parte, pelo novo cenário nacional e internacional do processo de internacionalização, a agência mudou o seu foco de atuação nos mercados de destino, reformulando os Centros de Distribuição em Centros de Negócios, expandindo suas ações para além da inserção comercial internacional via exportações, passando a estimular o avanço das empresas para fases de maior envolvimento e comprometimento de recursos no exterior, já que o foco no suporte logístico às exportações evoluiu para um apoio global à instalação de empresas no exterior, abrangendo estudos de viabilidade, de inteligência comercial, suporte informacional, jurídico, administrativo, relacional e físico, até a definitiva instalação de uma operação local. As empresas localizadas nos centros de negócios ainda contam com serviços e relatórios de inteligência de mercado mais customizados às suas demandas, além da possibilidade de trabalhos de promoção comercial, como visitas técnicas e missões, organizadas nas pontas de destino, o que aumenta consideravelmente a escolha de parceiros mais bem alinhados com os interesses das empresas entrantes, assim como do fortalecimento de uma rede de interação constante no local.

Diferentemente da ideia de centro de distribuição, os Centros de Negócios cobriram inicialmente os trabalhos de relações públicas com atores-chave do processo de instalação local, para, posteriormente, assumirem o papel de plataformas de acesso aos mercados internacionais considerados estratégicos. Esses Centros de Negócios foram localizados na Ásia (Pequim - China), Oriente Médio (Dubai - Emirados Árabes Unidos), América do Norte (Miami - EUA), América Central e Caribe (Havana - Cuba), Europa Ocidental (Bruxelas - 
Bélgica), Leste Europeu (Moscou - Rússia) e África (Luanda - Angola). Os serviços disponíveis em cada Centro de Negócios encontram-se na Figura 9.

\begin{tabular}{|c|c|c|c|c|}
\hline Escritório & $\begin{array}{c}\text { Estudo de } \\
\text { mercado } \\
\text { customizado }\end{array}$ & $\begin{array}{c}\text { Agenda de } \\
\text { negócios }\end{array}$ & $\begin{array}{c}\text { Apoio à instalação } \\
\text { local }\end{array}$ & Incubadora \\
\hline Angola & & $\mathrm{X}$ & $\mathrm{X}$ & \\
\hline Bélgica & & $\mathrm{X}$ & $\mathrm{X}$ & \\
\hline China & & $\mathrm{X}$ & $\mathrm{X}$ & \\
\hline Cuba & & $\mathrm{X}$ & $\mathrm{X}$ & \\
\hline EUA & $\mathrm{X}$ & $\mathrm{X}$ & $\mathrm{X}$ & $\mathrm{X}$ \\
\hline Oriente Médio & & $\mathrm{X}$ & $\mathrm{X}$ & $\mathrm{X}$ \\
\hline Rússia & $\mathrm{X}$ & $\mathrm{X}$ & $\mathrm{X}$ & \\
\hline Colômbia & & $\mathrm{X}$ & $\mathrm{X}$ & \\
\hline
\end{tabular}

Figura 9 - Portfólio de serviços e escritórios da Apex-Brasil no exterior

Fonte: APEX- Brasil. Relatório sobre Programa de Internacionalização Apex-Brasil

Além disso, em Bruxelas, passou a funcionar também o Brazilian Business Affairs (BBA), escritório da Apex-Brasil em parceria com a Confederação Nacional da Indústria (CNI), que acompanha as tendências e deliberações da União Europeia.

Outro braço da APEX-Brasil, em 2007, a agência definiu como um dos focos para o período de 2008 a 2010 o apoio à internacionalização das empresas brasileiras em todas as suas fases, desde a pré-exportação até a instalação de subsidiárias no exterior, dando origem, em 2008, ao Programa Extensão Industrial Exportadora (PEIEX). O PEIEX atua para ampliar a desempenho de empresas não exportadoras ou iniciantes. Com o objetivo de oferecer serviços de capacitação em exportação para empresas, os 38 Núcleos Operacionais do PEIEX estão instalados em 13 estados brasileiros (Alagoas, Bahia, Ceará, Goiás, Minas Gerais, Pará, Paraná, Pernambuco, Rio de Janeiro, Rio Grande do Sul, Santa Catarina, São Paulo e Sergipe) e no Distrito Federal. A Apex-Brasil também estabeleceu parceria com instituições de ensino e pesquisa de excelência, com o intuito de realizar um diagnóstico tecnológico e gerencial das empresas, a fim de sugerir medidas que permitam as mesmas iniciar suas exportações de forma segura e direcionada.

Ainda em 2008, a agência brasileira criou a Unidade de Relações com Clientes, implantando uma plataforma de CRM (Gerenciamento de Relações com Clientes), que possibilita a todos os funcionários da mesma uma visão única dos clientes e de suas necessidades. Atualmente, a Apex-Brasil já está presente, com Unidades de Atendimento em 
catorze estados brasileiros, em cooperação, principalmente, com a Confederação Nacional da Indústria (CNI) e as Federações de Indústrias.

Embora seja uma Agência jovem, em 2009, a Apex-Brasil foi eleita pelo Banco Mundial como a $2^{\mathrm{a}}$ melhor agência em atendimento ao investidor (um dos quesitos de avaliação das agências) entre 181 instituições de todo o mundo, conquistando o topo do ranking da América Latina e Caribe. Em 2010, a Agência foi premiada com o TPO Network Award como melhor agência de promoção comercial entre os países em desenvolvimento. A Apex-Brasil atende empresas de todos os portes, e em todos os estágios de maturidade exportadora. Contudo, o foco principal é nas pequenas e médias, e nos setores estratégicos para o desenvolvimento e a competitividade do Brasil. Atualmente, agência apoia mais de 13 mil empresas de 81 setores da economia brasileira. A Apex-Brasil também coordena os esforços de atração de investimentos estrangeiros diretos para o Brasil com foco em setores estratégicos para a economia brasileira e visando à competitividade e ao desenvolvimento do país. O objetivo é atrair investimentos produtivos que facilitem a transferência de tecnologias inovadoras para as empresas brasileiras e contribuam para o adensamento das cadeias produtivas e para as exportações e a inserção internacional ativa do Brasil. 


\section{FORMULAÇÃO DE HIPÓTESES}

Levando em consideração o arcabouço teórico apresentado, as seguintes hipóteses foram formuladas para o estudo:

\subsection{Informações Assimétricas}

A lógica da internacionalização é atrelada à busca das empresas em superar as imperfeições do mercado a partir dos fatores específicos da indústria na qual estão inseridas, dado que esses fatores determinam consideravelmente a internalização de mercados para produtos e atividades intermediários, propiciando, por conseguinte, estruturas de produção verticalizadas (Buckley \& Casson, 2002; Williamson, 1991). A estratégia de localização de uma empresa verticalmente integrada é predominantemente determinada pela ação combinada das vantagens comparativas, barreiras comerciais e incentivos regionais à internalização (Buckley \& Casson, 2002, p.35); a firma será multinacional sempre que esses fatores tornarem ideal a posição de diferentes estágios da produção em diferentes países (Buckley \& Casson, 2002, p.35). Williamson (1991) retoma os preceitos de Coase (1937), acerca da internalização e custos de transação, focando em mercados e hierarquias, empenhado em identificar os fatores ambientais que, relacionados a fatores humanos, expliquem as circunstâncias sob as quais será custoso elaborar, implementar e se fazer respeitar contratos (Williamson, 1991). Conforme defende Williamson (1991, p.25), a empresa, "ao enfrentar tais dificuldades, e considerando os riscos colocados por simples contratos (ou aqueles incompletos) de condições contingentes, [...] poderá decidir evitar o mercado e recorrer a modelos hierárquicos de organização.”.

Do argumento de Williamson (1991), decorre-se que as questões determinantes de uma organização, sua forma, escopo e fronteiras, encontram-se nas decisões entre contratar agentes no mercado ou utilizar a sua própria estrutura (constituindo hierarquias), no clássico questionamento make or buy. Em outras palavras, as imperfeições de mercados direcionam os tomadores de decisões a decidir mediante uma análise dos custos de transação, sendo o seu resultado a internacionalização das empresas. Os custos inerentes de se redigir e executar contratos completos por meio de um mercado variam segundo as características das pessoas encarregadas de tomar as decisões, as quais estão inseridas na transação, por um lado, e nas propriedades objetivas de mercado, de outro (Williamson, 1991), ou seja, ainda que os fatores 
humanos e ambientais que impedem o intercâmbio entre as empresas (por meio do mercado) se manifestem de um modo diferente dentro da empresa, o mesmo conjunto de fatores se aplica a ambos.

Dessas considerações, é possível concluir que as organizações empresariais e suas transações no mercado ocorrem e são influenciadas pela incerteza e complexidade do ambiente e pelo oportunismo e racionalidade limitada (Simon, 1972, 1983) característicos do comportamento humano. Os comportamentos oportunistas dos agentes nos mercados, como a falta de sinceridade e honestidade, tendem a elevar o custo percebido pelos tomadores de decisão, principalmente em contratos de longo prazo, dadas as complexidades e incertezas que geram no ambiente, o que acaba por determinar a estratégia da empresa: optar pelo mercado ou pelas hierarquias (Williamson, 1991).

Onde a incerteza e complexidade dominar o ambiente, a hierarquia se torna o melhor meio de se reduzir os custos de governança (Buckley \& Casson, 2002). Logo, ao longo do processo de análise dos mercados, a decisão de internacionalização de uma empresa, bem como a decisão de internalizar a produção a partir de uma filial no exterior ou externalizá-la com um agente estrangeiro, via contratos, será determinada por dois fatores básicos: questões atreladas aos custos de transação e da transferência de conhecimento (Teece, 1986a; 1986b).

As APEIs têm funções de comunicação e divulgação de informações a respeito de mercados (Wells \& Wint, 2001). As empresas locais podem simplesmente restringir os fluxos de informação para evitar a entrada de novos concorrentes potenciais. Campanhas de promoção constituem um mecanismo importante para comunicar todas as características que tornam um país de acolhimento atraente para os investidores, incluindo as políticas existentes e iniciativas de reforma recentes (Wells \& Wint, 2001). Além disso, as APEIs podem desempenhar um papel na coordenação da maioria das atividades destinadas a melhorar o ambiente de negócios no país de acolhimento. Este papel pode variar de prestação de assistência à busca de mercado potencial a auxilio dos investidores em seus problemas diários existente para fazer lobby para a política chave e reformas legais (Morisset \& AndrewsJohnson, 2004).

A economia dos custos de transação (ECT) sugere que a assimetria de informações aumenta os custos de transação, uma vez que são estabelecidas salvaguardas contra oportunismos (Klein, Crawford, \& Alchian, 1978; Williamson, 1985; Dyer, 1997) e, com isso, reduz as transações, consequentemente, os fluxos comerciais e de investimentos. 
Assim, a presença da APEI, com a disponibilidade de informações do mercado (consumidores, fornecedores, instituições), reduz a incerteza e as assimetrias de informações. Tais argumentos nos levam as hipóteses seguintes:

- Hipótese 1a (H1a): A presença da APEI do país de origem do capital no país hospedeiro aumenta o fluxo do país de origem da APEI para o país hospedeiro.

- Hipótese 1b (H1b): A presença da APEI do país de origem do capital no país hospedeiro aumenta o fluxo do país hospedeiro para o país de origem da APEI.

No intuito de testar a hipótese para os fluxos de exportação, importação, saída de IDE e entrada de IDE, essas hipóteses foram desdobradas, conforme a Figura 10:

\begin{tabular}{|c|l|}
\hline \multicolumn{2}{|c|}{ Hipóteses } \\
\hline H1aI & $\begin{array}{l}\text { A presença da APEX no país hospedeiro aumenta o fluxo de exportação do Brasil para o } \\
\text { país hospedeiro. }\end{array}$ \\
\hline H1aII & $\begin{array}{l}\text { A presença da APEI do país de origem no Brasil aumenta o fluxo de importação do Brasil } \\
\text { do país de origem. }\end{array}$ \\
\hline H1aIII & $\begin{array}{l}\text { A presença da APEX no país hospedeiro aumenta o fluxo de IDE brasileiro no país } \\
\text { hospedeiro. }\end{array}$ \\
\hline H1aIV & $\begin{array}{l}\text { A presença da APEI do país de origem no Brasil aumenta o fluxo de IDE do país de origem } \\
\text { no Brasil. }\end{array}$ \\
\hline H1bI & $\begin{array}{l}\text { A presença da APEI do país de destino do fluxo no Brasil aumenta o fluxo de exportação do } \\
\text { Brasil para o país de destino. }\end{array}$ \\
\hline H1bII & $\begin{array}{l}\text { A presença da APEX no país de origem do fluxo aumenta o fluxo de importação do Brasil } \\
\text { deste país. }\end{array}$ \\
\hline H1bIII & $\begin{array}{l}\text { A presença da APEI do país de destino do fluxo no Brasil aumenta o fluxo de IDE do Brasil } \\
\text { para o país de destino. }\end{array}$ \\
\hline H1bIV & $\begin{array}{l}\text { A presença da APEX no país de origem do fluxo aumenta o fluxo de IDE do país de origem } \\
\text { para o Brasil. }\end{array}$ \\
\hline
\end{tabular}

Figura 10 - Desdobramentos das hipóteses H1a e H1b

Fonte: Elaborado pela autora.

\subsection{Aprendizagem}

Uma fonte de vantagem competitiva para a firma, por exemplo, é o know-how, que se apresenta em distintos cenários como o diferencial para expansão e/ ou controle do mercado. Teece $(1998$, p.57) conceitua da seguinte maneira "os ativos de conhecimento são, muitas vezes, inerentemente difíceis de copiar; ademais, como os ativos físicos, alguns ativos de 
conhecimento desfrutam de proteção contra furtos sob as leis de propriedade intelectual de nações individuais".

Baseado nas teorias de gestão de conhecimento, quanto maior o tempo de atuação, maior será o ganho com a experiência e aprendizado. Partindo-se dessa ideia a seguinte hipótese foi formulada:

- Hipótese 2a (H2a): A aprendizagem da APEI do país de origem no país hospedeiro aumenta o fluxo do país de origem para o país hospedeiro.

- Hipótese 2b (H2b): A aprendizagem da APEI do país de origem no país hospedeiro aumenta o fluxo do país hospedeiro para o país de origem.

Assim como para as hipóteses H1a e H1b, com o intuito de testar a hipótese para os fluxos de exportação, importação, saída de IDE e entrada de IDE, essas hipóteses foram desdobradas, conforme a Figura 11:

\begin{tabular}{|l|l|}
\hline \multicolumn{2}{|c|}{ Hipóteses } \\
\hline H2aI & $\begin{array}{l}\text { A aprendizagem da APEX no país hospedeiro aumenta o fluxo de exportação do Brasil para } \\
\text { o país hospedeiro. }\end{array}$ \\
\hline H2aII & $\begin{array}{l}\text { A aprendizagem da APEI do país de origem no Brasil aumenta o fluxo de importação do } \\
\text { Brasil do país de origem. }\end{array}$ \\
\hline H2aIII & $\begin{array}{l}\text { A aprendizagem da APEX no país hospedeiro aumenta o fluxo de IDE brasileiro no país } \\
\text { hospedeiro. }\end{array}$ \\
\hline H2aIV & $\begin{array}{l}\text { A aprendizagem da APEI do país de origem no Brasil aumenta o fluxo de IDE do país de } \\
\text { origem no Brasil. }\end{array}$ \\
\hline H2bI & $\begin{array}{l}\text { A aprendizagem da APEX no país hospedeiro aumenta o fluxo de importação do Brasil com } \\
\text { origem no país hospedeiro da agência. }\end{array}$ \\
\hline H2bII & $\begin{array}{l}\text { A aprendizagem da APEI do país de origem no Brasil aumenta o fluxo de exportação do } \\
\text { Brasil para o país de origem da agência. }\end{array}$ \\
\hline H2bIII & $\begin{array}{l}\text { A aprendizagem da APEX no país hospedeiro aumenta o fluxo de IDE do país hospedeiro } \\
\text { para o Brasil. }\end{array}$ \\
\hline H2bIV & $\begin{array}{l}\text { A aprendizagem da APEI do país de origem no Brasil aumenta o fluxo de exportação do } \\
\text { Brasil para o país de origem da agência. }\end{array}$ \\
\hline
\end{tabular}

Figura 11 - Desdobramentos das hipóteses H2a e H2b

Fonte: Elaborado pela autora.

\subsection{Distância cultural}

Baseado no trabalho de Johanson e Vahlne (1977; 1990), países com distância cultural mais elevada acarretam em um ambiente mais incerto para as empresas. Em países com maior 
distância cultural, o impacto da presença da APEI tente a ser maior, uma vez que a mesma atua na redução das incertezas do mercado. Para isso, foi formulada a seguinte hipótese:

- Hipótese 3 (H3): A presença da APEI reduz o efeito negativo da distância cultural sobre o fluxo do país de origem para o país hospedeiro.

A figura 12 mostra os desdobramentos da Hipótese H3 para cada um dos fluxos.

\begin{tabular}{|l|l|}
\hline \multicolumn{2}{|c|}{ Hipóteses } \\
\hline H3a & $\begin{array}{l}\text { A APEX reduz o efeito negativo da distância cultural sobre o fluxo de exportação do Brasil } \\
\text { para o país hospedeiro da agência. }\end{array}$ \\
\hline H3b & $\begin{array}{l}\text { A APEI reduz o efeito negativo da distância cultural sobre o fluxo de importação do Brasil } \\
\text { em relação ao país de origem da agência. }\end{array}$ \\
\hline H3c & $\begin{array}{l}\text { A APEX reduz o efeito negativo da distância cultural sobre o fluxo de saída de IDE do } \\
\text { Brasil para o país hospedeiro da agência. }\end{array}$ \\
\hline H3d & $\begin{array}{l}\text { A APEI reduz o efeito negativo da distância cultural sobre o fluxo de entrada de IDE no } \\
\text { Brasil em relação ao país de origem da agência. }\end{array}$ \\
\hline
\end{tabular}

Figura 12 - Desdobramentos da hipótese $\mathrm{H3}$

Fonte: Elaborado pela autora

\subsection{Distância geográfica}

O estudo de Håkanson e Ambos (2010) mostra que entre as variáveis de previsão dos fluxos de investimento, a distância geográfica explica a maior parte da variância. Os autores sugerem que deve ser dado um papel mais proeminente a distância física nas investigações empíricas sobre as decisões de negócios internacionais - como as decisões sobre mercado externo e seleções de países-alvo e os modos de entrada, entre outros - para a qual distância psíquica pode ser relevante.

A proximidade geográfica pode facilitar significativamente a interpretação e compreensão de um ambiente externo (Håkanson \& Ambos, 2010). As empresas podem, por exemplo, ser bem aconselhadas para localizar pontes regionais perto de mercados estrangeiros com o intuito de aumentar a qualidade de suas informações e tomada de decisões que lhes digam respeito. Assim, pode-se dizer que a distância funciona como proxy de distância psíquica, o que permite a formulação da hipótese seguinte:

- Hipótese 4 (H4): A presença da APEI reduz o efeito negativo da distância geográfica sobre o fluxo do país de origem para o país hospedeiro da agência. 
A figura 13 mostra os desdobramentos da Hipótese H4 para cada um dos fluxos.

\begin{tabular}{|l|l|}
\hline \multicolumn{2}{|c|}{ Hipóteses } \\
\hline H4a & $\begin{array}{l}\text { A APEX reduz o efeito negativo da distância geográfica sobre o fluxo de exportação do } \\
\text { Brasil para o país hospedeiro da agência. }\end{array}$ \\
\hline H4b & $\begin{array}{l}\text { A APEI reduz o efeito negativo da distância geográfica sobre o fluxo de importação do } \\
\text { Brasil em relação ao país de origem da agência. }\end{array}$ \\
\hline H4c & $\begin{array}{l}\text { A APEX reduz o efeito negativo da distância geográfica sobre o fluxo de saída de IDE do } \\
\text { Brasil para o país hospedeiro da agência. }\end{array}$ \\
\hline H4d & $\begin{array}{l}\text { A APEI reduz o efeito negativo da distância geográfica sobre o fluxo de entrada de IDE no } \\
\text { Brasil em relação ao país de origem da agência. }\end{array}$ \\
\hline
\end{tabular}

\section{Figura 13 - Desdobramentos da hipótese H4}

Fonte: Elaborado pela autora

\subsection{Controle Societário e Autonomia Organizacional}

Alguns estudos identificaram que diferentes formas de controle societário, autonomia organizacional e subordinação parecem resultar em diferentes desempenhos das agências (Wells \& Wint, 2000; Hibbert, 1989; ITC, 2000).

As APEIs podem ser puramente públicas, puramente privadas ou mistas (público e privadas) (ITC, 2000; Wells \& Wint, 2000). De acordo com ITC (2000), uma organização de promoção bem-sucedida apresenta as seguintes características: a natureza da organização deve ser mista, público-privada, assegurando-se que as operações tenham metodologias e objetivos do setor privado; ser independente de autoridades políticas, garantindo continuidade; que os mecanismos de financiamento sejam, em alguma medida, independentes do governo central, exigindo participação do setor privado em parte do orçamento operacional.

Em contraste com as agências públicas, as público-privadas tendem a estabelecer redes elaboradas de escritórios no exterior, independentes de redes de consulados ou embaixadas de seus países (Wells \& Wint, 2000). As agências público-privadas tendem a dedicar mais esforço para o desenvolvimento de sistemas de informação e controle do que agências públicas (Wells \& Wint, 2000). As agências público-privadas não dependem de redes existentes de escritórios diplomáticos (Wells \& Wint, 2000), demonstrando seu compromisso com a promoção do investimento através da construção de uma impressionante rede de escritórios promocionais stand-alone (Wells \& Wint, 2000).

Assim, características organizacionais diversas resultam em diferentes desempenhos das agências. Partindo-se dessa ideia as seguintes hipóteses foram formuladas: 
- Hipótese 5a (H5a): Agências com estrutura pública e privada apresentam impacto maior do que aquelas que são formadas apenas por capital público.

- Hipótese 5b (H5b): Agências com escritórios próprios têm impacto maior sobre os fluxos do que as agências com escritórios nos consulados do país de origem no país hospedeiro.

- Hipótese 5c (H5c): Agências subordinadas a ministérios apresentam impacto menor do que aquelas subordinadas à presidência.

A Figura 14 mostra os desdobramentos das Hipóteses H5a, H5b e H5c.

\begin{tabular}{|l|l|}
\hline \multicolumn{2}{|c|}{ Hipóteses } \\
\hline H5aI & $\begin{array}{l}\text { O impacto de APEIs de capital público-privado no fluxo de importação brasileiro do país de } \\
\text { origem da APEI é maior do que o impacto das APEIs de capital público. }\end{array}$ \\
\hline H5aII & $\begin{array}{l}\text { O impacto de APEIs com capital público-privado no fluxo de saída de IDE do Brasil para o } \\
\text { país de origem da APEI é maior do que o de APEI de capital público. }\end{array}$ \\
\hline H5bI & $\begin{array}{l}\text { O impacto de APEIs com escritório independente no fluxo de importação brasileiro do país } \\
\text { de origem da APEI é maior do que o de APEIs com escritórios dentro de consulados. }\end{array}$ \\
\hline H5bII & $\begin{array}{l}\text { O impacto de APEIs com escritório independente no fluxo de saída de IDE do Brasil para o } \\
\text { país de origem da APEI é maior do que o de APEIs com escritórios dentro de consulados. }\end{array}$ \\
\hline H5cI & $\begin{array}{l}\text { O impacto de APEIs subordinadas a ministérios no fluxo de importação brasileiro do país de } \\
\text { origem da APEI é menor do que o de APEIs subordinadas à presidência. }\end{array}$ \\
\hline H5cII & $\begin{array}{l}\text { O impacto de APEIs subordinadas a ministérios no fluxo de saída de IDE do Brasil para o } \\
\text { país de origem da APEI é menor do que o de APEIs subordinadas à presidência. }\end{array}$ \\
\hline
\end{tabular}

Figura 14 - Desdobramentos das hipóteses H5a, H5b e H5c

Fonte: Elaborado pela autora

O capítulo seguinte apresentará a metodologia utilizada para a realização da pesquisa e o teste das hipóteses levantadas. 


\section{METODOLOGIA DE PESQUISA}

$\mathrm{Na}$ presente tese, o problema levantado relaciona a presença das APEIs e seus efeitos sobre os fluxos comerciais (exportação e importação) e os fluxos de investimento direto estrangeiro (IDE) (entrada e saída). Neste contexto, a questão que motiva é se a presença das APEIs exerce algum impacto sobre os fluxos. Nota-se, de imediato, uma natureza exploratória do problema sugerido, uma vez que pretende descortinar camadas de reflexão sobre a presença da APEI, como se dá o seu impacto, qual a diferença do impacto nos diferentes ambientes institucionais e, por fim, a descrição de sua participação e importância na inserção internacional do país de origem e a possibilidade de um aumento da competitividade da indústria nacional.

Diversas classificações da natureza de pesquisa são encontradas em Malhotra (2001) e Sampieri, Collado e Lucio (1991). Dentre elas, os autores descrevem como as mais relevantes as pesquisas exploratórias, descritivas e conclusivas.

Os estudos científicos têm características especificas no que tange ao seu caráter ou tipo. De forma geral, os estudos podem ter caráter exploratório, descritivo, explanatório ou casual/preditivo. As linhas de análise desenvolvidas por Selltiz (1987) e Gil (2011) mostram que a metodologia a ser adotada em um estudo de pesquisa depende da sua natureza e pode ser classificada em três tipos: exploratórios, descritivos e causais.

A pesquisa exploratória visa prover o pesquisador de maior conhecimento sobre o tema ou problema de pesquisa em perspectiva sendo apropriada para os primeiros estágios da investigação quando a familiaridade, o conhecimento e a compreensão do fenômeno por parte do pesquisador são poucos ou inexistentes. O método utilizado é o levantamento de dados através de fontes secundárias, levantamentos de experiências, estudos de casos e observação informal (Malhotra, 2001, p. 187).

Já o estudo denominado pesquisa conclusiva causal é realizado para identificar a natureza da relação entre duas ou mais variáveis (Malhotra, 2001). O pressuposto básico da pesquisa causal é que algumas variáveis causam ou afetam o valor de outras variáveis. Embora as causas não possam ser provadas pela ciência comportamental, se certas evidências forem encontradas, pode-se supor um alto grau de confiança de que as inferências causais sejam corretas (Selltiz, 1987).

Os autores justificam que os fenômenos estudados pelas ciências sociais, como todo objeto que se tenta explicar por meio do conhecimento científico, são intrinsecamente complexos, pelo fato de estarem inter-relacionados por uma malha de causalidade a diversos 
outros fatores (ou outros tipos de fenômenos), que ocorrem dentro de uma sociedade e que comprovam a correlação dos estudos causais nas ciências sociais. Mesmo considerando a dificuldade de fazer asserções causais através da pesquisa correlacional, os pesquisadores não manipulam uma variável, apenas observam os efeitos subsequentes em outra, medem ambas as variáveis e observam a relação entre as duas. Nesta pesquisa, a orientação foi inicialmente exploratória e descritiva, uma vez que se buscou compreender o processo de internacionalização das empresas, bem como descrever como o mesmo ocorre e qual o papel das APEIs. A partir disso, procurou se estabelecer relações entre dois ou mais conceitos ou o grau de relação entre esses conceitos.

\subsection{Método do Estudo}

Pode-se dizer que o método científico de pesquisa é um conjunto de passos específicos e claramente determinados para a obtenção de um conhecimento, passos estes aceitos pelas pessoas que estudaram e militaram na área em que foi realizada a pesquisa (Selltiz, 1987). O desenvolvimento de uma pesquisa acadêmica, inclusive a sua condução, envolve mais do que suposições (Craswell, 2007) ou paradigmas (Mertens, 1998); demanda, necessariamente, a definição de estratégias e procedimentos metodológicos que sejam capazes de permitir ao pesquisador explorar as alegações de conhecimento pretendidas e sugeridas, com vistas a oferecer condições para que as suas intepretações e considerações finais sejam minimamente válidas. A dimensão metodológica, nestes termos, além de fundamental, é aquela que, a partir do problema e objetivos de pesquisas suscitados, identifica a sua natureza e determina os seus respectivos procedimentos e práticas de análise tidas como as mais adequadas, porque validados academicamente para os seus fins previamente propostos.

De forma clássica os métodos de pesquisa são divididos em seis tipos: a bibliografia, $o$ survey, a experimentação, o estudo de caso, a história e a pesquisa-ação.

Para cumprimento dos objetivos deste estudo, foram realizadas, conforme indicação de Malhotra (2001), primeiramente uma pesquisa exploratória através da consulta a fontes bibliográficas e documentais, tais como livros, artigos, relatórios e estatísticas públicas. Os dados para a realização da pesquisa foram obtidos através dos relatórios estatísticos do Ministério do Desenvolvimento, Indústria e Comércio, World Bank, Heritage Foundation, Doing Business, Quality of Government, World Economic Forum - Global Competitiveness Index, The GEODIST database, BIS Statistics Explorer - Bank for International Settlements, 
World Trade Organization, SICE (Foreign Trade Information System), além de entrevistas com as APEIs presentes no Brasil. Procurou-se também identificar nos artigos e documentos pesquisados pontos indicativos de interesse deste estudo. Utilizou-se o modelo do tipo interpretativo para demonstrar o resultado das análises, apoiado no processo de interpretação lógica e na capacidade de análise e discernimento reflexivo do pesquisador em relação ao objeto estudado.

Em seguida, depois de identificados os pontos de convergência, de divergência, tendências e regularidades, passou-se à organização e classificação das informações, sempre levando em consideração o escopo do estudo.

\subsection{Modelo Conceitual}

Schiffman e Kanuk (2000) definem um modelo como sendo uma representação da realidade destinada a mostrar relacionamentos entre vários elementos de um sistema ou processo em investigação. Para Sampieri, Collado e Lucio (1991), os modelos auxiliam na compreensão da realidade em estudo, na medida em que se relacionam os construtos envolvidos e proporcionam um panorama dos antecedentes ou consequências do construto analisado.

Para Nachmias e Nachmias (1996), após a definição do método da pesquisa, a elaboração de um modelo operacional permite a categorização de variáveis representativas e suas devidas relações, bem como evidencia as possíveis análises de dados que possibilitaram sustentar a resolução do problema. Assim, o modelo de operacionalização de variáveis é definido pelo autor como uma representação simplificada dos fenômenos. Nesse sentido, a possibilidade de entendimento da realidade por elementos categóricos se torna o meio para exploração dos fenômenos e suas variáveis, possibilitando um enquadramento dos dados e sua predição estatística.

O modelo permite especificar a relação entre as variáveis: dependentes (fluxos comerciais e de investimentos) e independentes (presença da APEI). As linhas seguidas para a montagem do modelo teórico que serviu de base para este estudo, bem como a sustentação teórica para a formulação das associações constantes do modelo utilizado, são apresentadas a seguir.

O modelo desenhado na Figura 15 não pretendia ser a generalização de todo fenômeno, mas estimulou a possibilidade de entendê-lo e adequá-lo ao fenômeno estudado. 
Para a consolidação do modelo, assumiu-se que a presença das APEI resulta em impacto sobre a internacionalização das empresas (também entendido como o investimento direto no exterior e exportação).

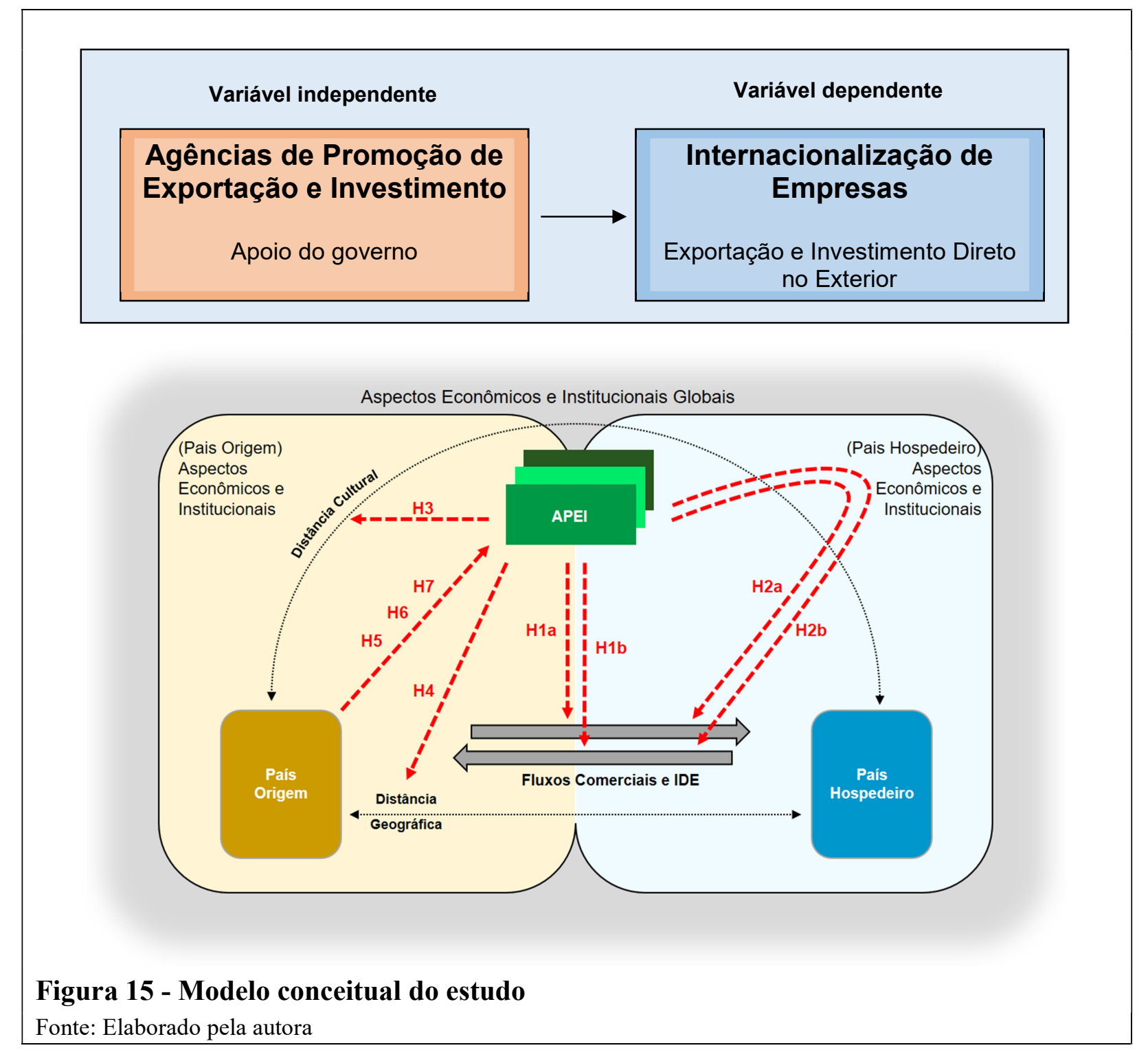

O modelo conceitual concebido para esta pesquisa reflete a questão problema proposta. Contudo, apesar de uma mesma base de análise, os fluxos comerciais e de investimento são influenciados por variáveis específicas, havendo, portanto, a necessidade da construção de dois modelos com variáveis que atendam as especificidades de cada tipo de fluxo. Esses modelos serão tratados como modelo A e modelo B, respectivamente para os fluxos comerciais e os fluxos de investimentos. 
Além disso, as hipóteses levantadas, ao abordarem especificações diferentes requerem modelos especiais para que possam ser testados. Neste contexto, serão apresentados os modelos modificados para os testes de hipóteses.

\subsection{Seleção e Descrição de Variáveis}

Desde a obra de Jan Tinbergen (1963), o tamanho dos fluxos de comércio bilaterais entre países pode ser aproximado pelo modelo gravitacional, por analogia com a teoria da gravitação newtoniana. Assim como os planetas são atraídos mutuamente na proporção de suas dimensões e proximidade, o comércio entre os países é atraído na proporção de seus respectivos produtos internos brutos (PIB) e proximidade geográfica.

Pesquisas recentes sobre a fundamentação teórica do modelo gravitacional destacam a importância de obter as especificações e as variáveis utilizadas no modelo através da teoria econômica. O artigo de Anderson e Wincoop Van (2003) foi particularmente importante neste sentido. Os autores mostram que o controle de custos comerciais relativos é crucial para um modelo gravitacional bem especificado. Seus resultados teóricos mostram que o comércio bilateral é determinado pelos custos comerciais relativos, ou seja, a propensão do país j para importar do país i é determinada pelo custo país j do comércio para i em relação à sua "resistência" global para as importações (custos comerciais médios ponderados) e para a "resistência" média enfrentando exportadores no país I; não simplesmente pelos custos comerciais absolutos entre os países i e j (Anderson \& Van Wincoop, 2003). Assim, os autores destacam a importância de obter variáveis específicas dos países. Kleinert e Toubal (2010), bem como Yeaple (2009) enfatizam o uso do modelo gravitacional na análise de fluxos entre países. Se o PIB do país hospedeiro, que é proxy para o tamanho do mercado doméstico, é relativamente grande, isso torna o país atraente para exportadores e investidores externos.

Estudiosos que usam modelos gravitacionais para os negócios internacionais e literaturas de comércio internacional há muito tempo reconheceram o importante papel da distância geográfica na construção do modelo (Fratianni \& Oh, 2009; Hamilton \& Winters, 1992; Wolf \& Weinschrott, 1973; Chen \& Moore, 2010; Kleinert \& Toubal, 2010). Chen e Moore (2010), bem como Kleinert e Toubal (2010) apontam que a distância geográfica é relacionada não apenas aos custos de comercialização, mas também ao custo de entrada para os investidores. Proximidade geográfica pode facilitar significativamente a interpretação e 
compreensão do um ambiente externo (Ambos \& Hakanson, 2010). Ambos e Hakanson (2010) salientam que empresas podem, por exemplo, ser aconselhadas a localizar pontes regionais perto de mercados estrangeiros para aumentar a qualidade de suas informações e tomada de decisões na região.

Numerosos estudos em negócios internacionais examinaram o impacto do ambiente econômico sobre a escolha do mercado estrangeiro e do modo de entrada (Iyer, 1997; Yeung, 1997; Zaheer \& Zaheer, 1997; Whitley, 1992; Caves, 1996; Berry et al., 2010). No que se refere ao IDE, vários pesquisadores (Schneider \& Frey, 1985; Laplane \& Sarti, 1997; Laplane \& Sarti, 2002; Gregory \& Oliveira, 2005; Serven \& Solimano, 1993; Wai \& Wong, 1982; Blejer \& Khan, 1984; Milman, 1996,) têm testado proxies de níveis de demanda do mercado e as taxas de crescimento do mercado de economias anfitriãs para ver se existe uma associação estatística entre essas proxies e dos fluxos de IDE (Wells \& Wint, 2000). Em geral, a maioria encontrou evidência de uma associação estatística. John H. Dunning (1999) sugeriu que uma das influências dominantes sobre o IDE foi o crescimento e tamanho do mercado do país anfitrião e Schneider e Frey (1985) encontraram relação estatisticamente significativa entre o IDE e procura do mercado e o crescimento do mercado, utilizando como proxies, respectivamente, o PIB per capita e a taxa de crescimento do PIB. Segundo Schneider e Frey, quanto maior a renda per capita, maior o fluxo de IDE.

De acordo com os estudos de Laplane e Sarti (1997), Laplane e Sarti (2002) e Gregory e Oliveira (2005), a taxa de crescimento do PIB, a inflação, e a taxa de câmbio (moeda local/US\$) estão entre as principais variáveis para a análise de investimentos em países em desenvolvimento, grupo do qual o Brasil faz parte. Os estudos de Serven e Solimano (1993), Wai e Wong (1982), e Blejer e Khan (1984) mostraram um efeito positivo do crescimento econômico sobre o IDE. Milman (1996), em uma análise dos determinantes do investimento privado em quatro países da América Latina (Argentina, Chile, México e Venezuela), mostrou que o crescimento anual do PIB foi considerado a variável de maior significância na determinação do IDE. Ou seja, o tamanho do mercado e o grau de estabilidade macroeconômica representam as principais forças que influenciaram os projetos de IDE na região.

A interação entre a economia institucional e a literatura sobre negócios internacionais favoreceu o surgimento de uma série de estudos sobre o impacto das instituições sobre o IDE. Basi (1963) e Aharoni (1966) estão entre os primeiros que incluíram as variáveis relacionadas às instituições políticas na análise do IDE. Basi (1963) e Aharoni (1966) concluiram em suas pesquisas que, após o tamanho do mercado e crescimento, a instabilidade política foi a 
influência dominante nos fluxos de investimento. Estudos realizados por Wells e Wint (2000) indicaram a instabilidade política como um dos principais fatores nas decisões dos investidores a não investir em um determinado país.

Com base na revisão teórica, propõe-se um modelo multidimensional de análise dos determinantes dos fluxos comerciais e de investimentos dentro da perspectiva do paradigma eclético, permitindo, assim, considerar fatores macroeconômicos, e institucionais na avaliação das variáveis relevantes. Variáveis macroeconômicas são recorrentes em grande parte dos modelos de análises e buscam captar os efeitos da estabilidade econômica e do desempenho dos agregados econômicos no país receptor sobre os fluxos. A inclusão de fatores institucionais tem a intenção de capturar os efeitos da qualidade do quadro institucional e de governança pública sobre os fluxos. Com isso, após testar inúmeras variáveis dos bancos de dados do Heritage Foundation, Doing Business, Quality of Goverment, World Economic Forum - Global Competitiveness Index, OECD, UNCTAD, IMF incluíram-se no estudo variáveis do Heritage Foundation, do Doing Business e do World Economic Forum - Global Competitiveness Index como proxies do ambiente institucional.

Inúmeros estudiosos de negócios internacionais têm argumentado que as diferenças entre as nações aumentam a incerteza psíquica ou cultural, impedindo que informação ou conhecimento flua entre países, aumentando assim o custo de fazer negócios através das fronteiras, isto é, os custos de transação associado com negócios internacionais (Berry et al., 2010). Embora reconhecendo conceitualmente a natureza multidimensional da distância, a maioria dos estudiosos de negócios internacionais que se comprometeram com trabalhos empíricos sobre a distância transnacional prestou atenção a uma única dimensão, ao usar dados de Hofstede (1980) na análise empírica.

Apesar de décadas de pesquisa, o campo ainda não possui uma análise abrangente das várias dimensões em que os países diferem uns dos outros. Por exemplo, Johanson e Vahlne (1977, p.24) aludiram as "diferenças de língua, educação, práticas de negócios, cultura e desenvolvimento industrial" como dimensões relevantes. Da mesma forma, Kogut e Singh (1988, p.413) referem-se genericamente as "características de um mercado estrangeiro", e calcularam distâncias entre pares de países utilizando uma métrica a partir dos constructos culturais de Hofstede (1980): aversão à incerteza, distância do poder, individualismo e masculinidade. Por seu lado, Barkema et al. (1996, p. 153) referem-se a "linguística, institucional, cultural e políticos fatores", mas mediram a construção em termos de distância cultural e blocos culturais dos países (Berry et al., 2010). Hennart e Larimo (1998, p. 517) se aproximaram de distância de uma perspectiva de transação custo, restringindo sua definição 
para "características culturais nacionais de origem e de acolhimento países", medindo-as a partir dos dados do Hofstede (Berry et al., 2010).

Berry et al. (2010) abordaram distância entre países do ponto de vista institucional, de modo a captar a rica diversidade de formas em que os países diferem, seguindo assim teorização institucional recente no campo dos negócios internacionais (Jackson \& Deeg, 2008; Pajunen, 2008). Definir e medir a distância entre países ao longo de múltiplas dimensões é importante, porque diferentes tipos de distância podem afetar as decisões das empresas ou individuais de maneiras diferentes, dependendo da dimensão da distância em exame. Por exemplo, enquanto a distância política pode dissuadir as empresas de criação de uma subsidiária de distribuição, pode incentivá-los a criar uma filial de fabricação que torna os produtos para o país anfitrião (Berry et al., 2010). Armados com uma definição multidimensional, Berry et al. (2010) argumentam que se pode entender melhor por diferentes tipos de distância o impacto positivo ou negativo sobre as decisões de gestão, os padrões de comércio do país, ou mesmo relações políticas entre os países (Berry et al., 2010).

Para esta tese seleciou-se as variáveis de distância cultural por Berry et al. (2010).

A literatura teórica e empírica sugere que as assimetrias de informação constituem um obstáculo significativo aos fluxos de capitais através das fronteiras internacionais (Harding \& Javorcik, 2011). As assimetrias de informação entre investidores nacionais e estrangeiros foram apresentadas como uma possível explicação para a preferência nacional, a tendência dos investidores de investir menos em ações estrangeira em relação à previsão de um modelo de escolha de portfólio (Stulz, 1981; Ahearne, Griever \& Warnock, 2005; Harding \& Javorcik, 2011). Gordon e Bovenberg (1996) argumentam que os investidores sabem, por viverem e trabalharem num determinado país, muito mais sobre as perspectivas econômicas do país do que de outros países, sendo que a falta de conhecimento dos estrangeiros pode resultar também num uso menos eficiente de recursos reais, devido, por exemplo, à sua menor capacidade de lidar com os aspectos idiossincráticos do direito nacional dos contratos e com os costumes locais que regem as relações de trabalho. Assim, a presença da APEI do país de origem aumenta o acesso às informações e aos conhecimentos sobre o mercado do país hospedeiro. A presença da APEI impactará positivamente nos fluxos ajudando a reduzir os custos de entrada no mercado. A APEI teria condições de transmitir informações corretas para potenciais investidores e, portanto, atua como um facilitador ou intermediário neste processo (Andrews \& Morisset, 2004).

O objetivo central deste estudo é analisar o impacto da APEI nos fluxos comerciais e de investimentos, assim, introduzimos a variável APEI nas equações. A presença da APEI é a 
nova variável que foi incluída. Para a seleção das variáveis de análise do ambiente institucional, foi utilizada a técnica de regressão passo a passo com o intuito de selecionar as melhores variáveis para o modelo.

As variáveis selecionadas para a análise dos fluxos comerciais estão na Figura 16:

\begin{tabular}{|c|c|c|}
\hline Variáveis & Proxies & Nome das Variáveis \\
\hline \multicolumn{3}{|c|}{ Variável Dependente } \\
\hline $\begin{array}{l}\text { Fluxo Comercial (Exportação e } \\
\text { Importação) }\end{array}$ & Fluxos de Exportação e Importação & exp ou imp \\
\hline \multicolumn{3}{|c|}{ Variáveis Independentes } \\
\hline $\begin{array}{l}\text { Tamanho da economia de origem do } \\
\text { fluxo }\end{array}$ & PIB país de origem & gdpppp_o \\
\hline $\begin{array}{l}\text { Tamanho da economia de destino do } \\
\text { fluxo }\end{array}$ & PIB país destino & gdpppp_d \\
\hline Distância física & Distância geográfica & Distance \\
\hline Demanda efetiva & PIB per capita & gdppercapita_ppp \\
\hline Estabilidade política & $\begin{array}{l}\text { Pontuação geral (nota da Heritage } \\
\text { Foundation) }\end{array}$ & hf_os \\
\hline Abertura Comercial & $\begin{array}{l}\text { Reflete a abertura da economia para } \\
\text { a importação de bens e serviços do } \\
\text { mundo e a capacidade individual do } \\
\text { cidadão de interagir livremente } \\
\text { como comprador ou vendedor na } \\
\text { esfera comercial internacional. }\end{array}$ & db_tab_dtb \\
\hline Estabilidade econômica & Taxa de câmbio & bis_reer \\
\hline Acordos comerciais & $\begin{array}{l}\text { Expressa o envolvimento do país } \\
\text { receptor do investimento em } \\
\text { projetos de integração regional ou } \\
\text { algum tipo de acordo de livre } \\
\text { comércio. Assume } 1 \text { quando o país é } \\
\text { parte de acordo de integração } \\
\text { regional e } 0 \text { em caso contrário. }\end{array}$ & $\begin{array}{l}\text { wto_fta (free trade agreement) } \\
\text { wto_pta (preferencial trade } \\
\text { agreement) }\end{array}$ \\
\hline $\begin{array}{l}\text { Presença da APEI do país de origem } \\
\text { no país de destino do fluxo }\end{array}$ & $\begin{array}{l}\text { Presença da apei no país parceiro. É } \\
\text { uma variável binária que tem o valor } \\
1 \text { para os países e anos em que a } \\
\text { agência brasileira está presente em } \\
\text { determinado pais e } 0 \text { no caso } \\
\text { contrário. }\end{array}$ & apex_ppp ou apei_ppp \\
\hline
\end{tabular}

\section{Figura 16 - Variáveis para a análise dos fluxos comerciais}

Fonte: Elaborado pela autora 
A Figura 17, por sua vez, apresenta as variáveis selecionadas para os modelos de análises dos fluxos de IDE dos países:

\begin{tabular}{|c|c|c|}
\hline Variáveis & Proxies & Nome das Variáveis \\
\hline \multicolumn{3}{|c|}{ Variável Dependente } \\
\hline $\begin{array}{l}\text { Fluxo de Investimento (IDE entrada } \\
\text { e IDE saída) }\end{array}$ & Fluxos de Investimentos & $\begin{array}{l}\text { loginvestout } \\
\text { loginvestin }\end{array}$ \\
\hline \multicolumn{3}{|c|}{ Variáveis Independentes } \\
\hline $\begin{array}{l}\text { Tamanho da economia de origem do } \\
\text { fluxo }\end{array}$ & PIB país de origem & gdpppp_o \\
\hline $\begin{array}{l}\text { Tamanho da economia de destino } \\
\text { do fluxo }\end{array}$ & PIB país destino & gdpppp_d \\
\hline Distância física & Distância geográfica & Distance \\
\hline Demanda efetiva & PIB per capita & gdppercapita_ppp \\
\hline Incerteza nas relações econômicas & $\begin{array}{l}\text { Freedom from corruption (nota da } \\
\text { Heritage Foundation) }\end{array}$ & hf_ffc \\
\hline Liberdade fiscal & Fiscal freedom & hf_ff \\
\hline Facilidade de entrada & $\begin{array}{l}\text { Tempo necessário para iniciar um novo } \\
\text { negócios - dias }\end{array}$ & db_sb_timedays \\
\hline Busca por novos fornecedores & $\begin{array}{l}\text { Qualidade de fornecedores locais - nota } \\
\text { de } 1 \text { a } 7\end{array}$ & wef_gci_lsquality \\
\hline Risco de Mercado & $\begin{array}{l}\text { Comportamento ético das firmas - nota } \\
\text { de } 1 \text { a } 7\end{array}$ & wef_gci_ebf \\
\hline Estabilidade econômica & $\begin{array}{l}\text { Taxa de câmbio real (calculada a partir } \\
\text { da taxa de cambio nominal bilateral do } \\
\text { país doméstico em relação aos EUA (em } \\
\text { moeda local por US\$) }\end{array}$ & bis_reer \\
\hline Crescimento do mercado & Variação do PIB (\%) & gdp_var \\
\hline Instabilidade econômica & $\begin{array}{l}\text { Inflação no país receptor do } \\
\text { investimento (em variação \% ao ano) }\end{array}$ & Inflation \\
\hline $\begin{array}{l}\text { Presença da APEI do país de origem } \\
\text { no país de destino do fluxo }\end{array}$ & $\begin{array}{l}\text { Presença da apei no país parceiro. É uma } \\
\text { variável binária que tem o valor } 1 \text { para } \\
\text { os países e anos em que a agência } \\
\text { brasileira está presente em determinado } \\
\text { pais e } 0 \text { no caso contrário. }\end{array}$ & apex_ppp ou apei_ppp \\
\hline
\end{tabular}

Figura 17- Variáveis para a análise dos fluxos de investimento

Fonte: Elaborado pela autora

\subsection{Modelo Econométrico}

Para estimar o efeito das APEIs sobre os fluxos de comércio e investimento, adotou-se um estimador de painéis dinâmicos com efeito fixo. A utilização de um modelo dinâmico com uma variável dependente defasada - é adotada para reduzir potenciais vieses de variáveis 
omitidas que existam em um modelo estático, uma vez que alguns determinantes dos fluxos possam estar relacionados com a criação de APEIs.

Um dos principais problemas metodológicos a ser enfrentado é a questão da endogeneidade - que estaria relacionando a presença da APEI ser o efeito de outros fatores.

O problema de endogeneidade surge muitas vezes ao estimar o impacto das políticas comerciais e de investimentos, uma vez que estas não são puramente exógenas (Wto \& Unctad, 2012). Os fluxos comerciais serão susceptíveis de serem maiores com parceiros com os quais eles já negociam. Assim, as variáveis explicativas podem estar correlacionadas com o termo de erro da equação se características não observadas dos países pares afetarem os fluxos. Desta forma, problemas de endogeneidade podem surgir devido a variáveis omitidas que facilitam o comércio e não foram incluídas no modelo (Anderson \& Van Wincoop, 2003; Feenstra, 2004; Baldwin \& Taglioni, 2006).

Não há uma solução fácil para o problema da endogeneidade, contudo, o uso de painel de dados, com variáveis de efeitos fixos pode ajudar a superar parte do problema de endogeneidade devido ao viés variável omitida (Feenstra, 2004; Baldwin \& Taglioni, 2006; Wto \& Unctad, 2012; Baier \& Bergstrand; 2007).

Dados em painel ou dados longitudinais são caracterizados por possuírem observações em duas dimensões que em geral são o tempo e o espaço (Gujarati, 2006). Estes tipos de dados contêm informações que possibilitam uma melhor investigação sobre a dinâmica das mudanças nas variáveis, tornando possível controlar para o efeito das variáveis não observadas que são constantes no tempo. Outra vantagem é a melhoria na inferência dos parâmetros estudados, pois propicia mais graus de liberdade e maior variabilidade na amostra em comparação com dados em cross-section ou em séries temporais, o que refina a eficiência dos estimadores econométricos (Wooldridge, 2008). O painel permite que o efeito da APEI seja isolado no comércio bilateral em todos os períodos (Baier \& Bergstrand, 2007).

Contudo, modelos de painéis com efeitos fixos, ainda não resolvem algumas fontes de inconsistências comuns. Dado que alguns tradicionais fatores que explicam os fluxos analisados são ou pré-determinados ou endógenos, ou ambos, os níveis correntes dois fluxos podem depender dos seus valores passados. Posto isto, optamos por estimar modelos de painéis dinâmicos.

Esses estimadores de painéis dinâmicos do Método dos Momentos Generalizados (GMM), desenvolvidos por Holtz-Eakin, Newey, e Rosen (1988); Arellano e Bond (1991); Arellano e Bonver (1995); e Blundell e Bond (1998), são cada vez mais populares. 
Estes estimadores são concebidos para situações na qual a variável dependente é afetada pelas suas próprias realizações passadas. Posto isto, estão correlacionadas com realizações passadas e possivelmente atuais do erro.

Estimou-se o modelo usando o Arellano-Bond (1991) Generalized Method of Moments (GMM), o que permite o controle para vieses em potencial de alguns regressores com a inclusão de uma variável dependente defasada. A especificação auto regressiva é usada como uma representação parcimoniosa de escolhas anteriores e de outros determinantes dos fluxos estudados que estão fora do modelo principal e que podem afetar os coeficientes estimados

Usando esta especificação, aumentamos a nossa capacidade de estimar o verdadeiro efeito de APEI sobre os diferentes fluxos. O estimador system one-step difference GMM tornou-se uma abordagem padrão para estimar modelos de painel dinâmico (Arellano \& Bover, 1995; Blundell \& Bond, 1998; Roodman, 2009).

A consideração explícita do elemento dinâmico permite controlar para a possível existência de correlação entre os valores passados da variável dependente e os valores contemporâneos das demais variáveis explicativas, eliminando, assim, potenciais fontes de viés dos estimadores associadas com esse tipo de correlação (Baltagi, 2005; Arellano \& Bond, 1991).

Os modelos nesta pesquisa apresentam erros padrões robustos à heteroscedasticidade.

Dessa forma, apresentamos as equações que serão estimadas equações dinâmicas, como na Figura 18.

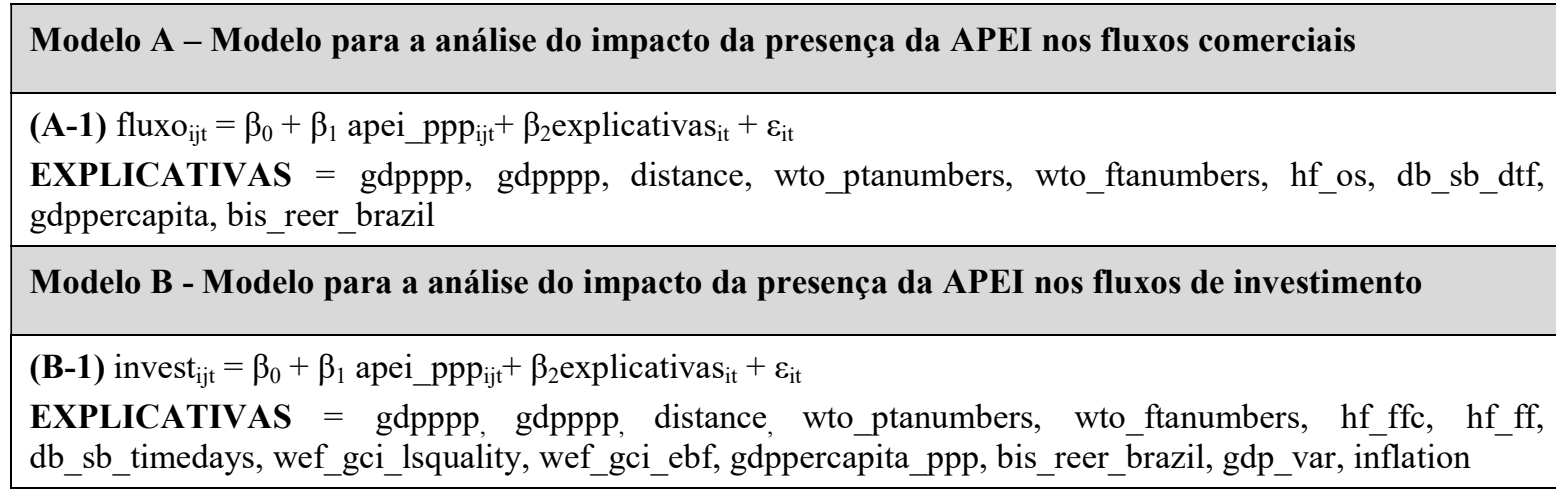

\section{Figura 18 - Modelos de equações dinâmicas para a realização do estudo}

Fonte: Elaborado pela autora

Onde nas equações $\mathrm{A}-1$ e $\mathrm{B}-1$ as variáveis fluxo $\mathrm{i}_{\mathrm{ij}(\mathrm{t}-1)}$ e invest $\mathrm{i}_{\mathrm{j}(\mathrm{t}-1)}$ correspondem às variáveis defasadas dos fluxos comerciais e dos investimentos, respectivamente, no período t1. 
Há várias condições que devem ser satisfeitas a fim de se obter resultados robustos por meio do sistema GMM. Em primeiro lugar, as estimativas devem cumprir o teste de ArellanoBond (AR). Esse teste verifica a existência de auto correlação serial nos resíduos da especificação que leva a estimadores inconsistentes. Para que os estimadores sejam consistentes, a hipótese nula de ausência de auto correlação de primeira ordem dos resíduos (AR1) deve ser rejeitado; e o de segunda ordem de auto correlação (AR2) precisa ser aceito. Em segundo lugar, a fim de mostrar que os instrumentos aplicados são válidos, o modelo precisa rejeitar a hipótese nula para o teste de Hansen de superidentificação. Além disso, o número de instrumentos utilizados no modelo deve ser menor do que o número de grupos de dados; caso contrário, o poder do teste de Hansen é diluído, e pode falsamente rejeitar a hipótese nula (Roodman 2008). Todas as estimativas foram realizadas por um passo GMM.

Além disso, para a realização da análise foram introduzidas dummies anuais, a fim de retirar eventuais choques econômicos da análise.

\subsection{Extensões Metodológicas}

Para o teste das hipóteses estabelecidas na seção anterior, foi necessária a realização de extensões metodológicas no modelo proposto.

Para analisar se o tempo de atuação da APEI tem relevância no seu impacto sobre os fluxos, faz-se necessário mais uma alteração metodológica. Logo, estimou-se uma versão modificada dos modelos, substituindo as variáveis de presença da APEI para as variáveis APEI aprendizagem, como na Figura 19:

Modelo A - Modelo para a análise do impacto da aprendizagem da APEI nos fluxos comerciais

(A-2) fluxo $_{\mathrm{ijt}}=\beta_{0}+\beta_{1}$ apei_pppa $\mathrm{ijt}_{\mathrm{ijt}}+\beta_{2}$ explicativas $_{\mathrm{it}}+\varepsilon_{\mathrm{it}}$

EXPLICATIVAS = gdpppp, gdpppp, distance, wto_ptanumbers, wto_ftanumbers, hf_os, db_sb_dtf, gdppercapita, bis_reer_brazil

Modelo B - Modelo para a análise do impacto da aprendizagem da APEI nos fluxos de investimento

(B-2) invest $_{\mathrm{ijt}}=\beta_{0}+\beta_{1}$ apei_pppa $\mathrm{pit}_{\mathrm{it}}+\beta_{2}$ explicativas $_{\mathrm{it}}+\varepsilon_{\mathrm{it}}$

EXPLICATIVAS = gdpppp, gdpppp, distance, wto_ptanumbers, wto_ftanumbers, hf_ffc, hf_ff, db_sb_timedays, wef_gci_lsquality, wef_gci_ebf, gdppercapita_ppp, bis_reer_brazil, gdp_var, imf_inflation

Figura 19 - Modelos modificados com as variáveis de aprendizagem da APEI

Fonte: Elaborado pela autora 
Onde APEIpppa $a_{\mathrm{ij}}$ é a variável que indica o tempo de presença da agência no país hospedeiro.

Para a análise do efeito das APEIs em relação à distância cultural, o modelo adaptado realiza as análises com a interação entre a variável de presença da APEI com as dimensões culturais propostas por Berry et al.(2010). Logo, os modelos testados foram:

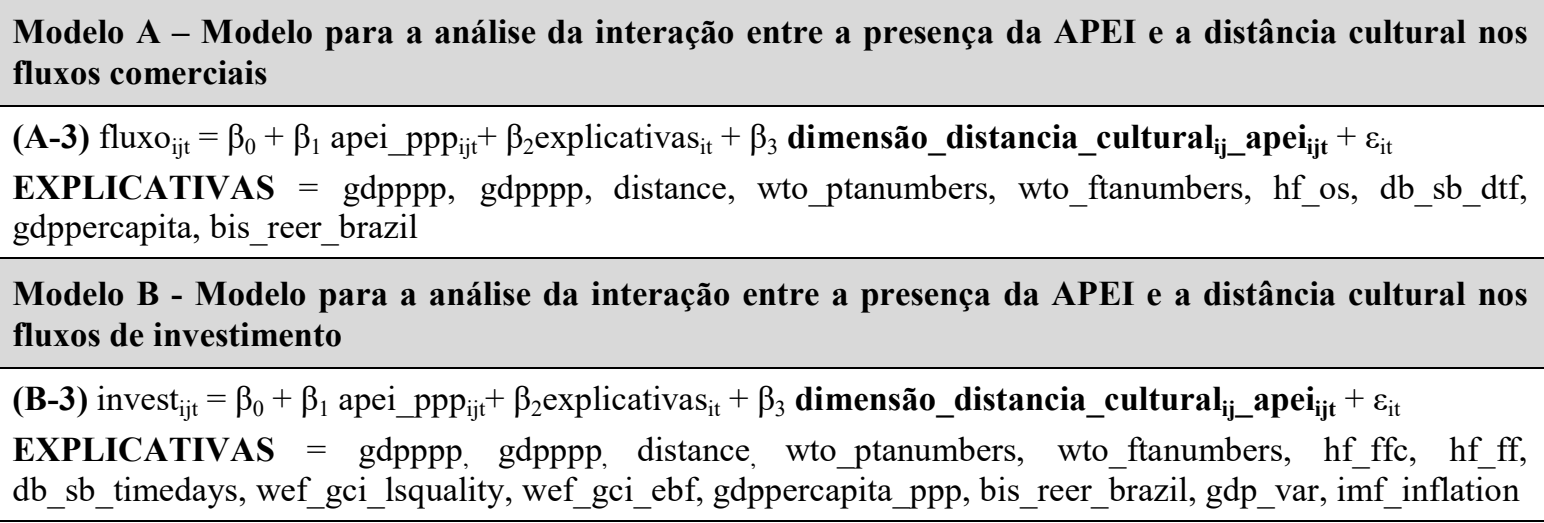

\section{Figura 20 - Modelos com a variável de interação entre APEI e distância cultural}

Fonte: Elaborado pela autora

Onde dimensão_distância_cultural $\mathrm{i}_{\mathrm{ij}}$ *APEI $\mathrm{A}_{\mathrm{ijt}}$ é a variável de interação entre a presença da APEI e as dimensões de distância cultural propostas por Berry et al. (2010).

Uma das extensões é verificar a existência de uma interação entre a distância geográfica e o impacto da presença da APEI sobre os diferentes fluxos. Para isso, estimou-se uma versão modificada das equações A-3.1e B-3.1 adicionando um termo de interação entre a variável de presença da APEI e a distância geográfica, medida em logaritmos. Logo, as equações foram modificadas como aparece na Figura 21, para:

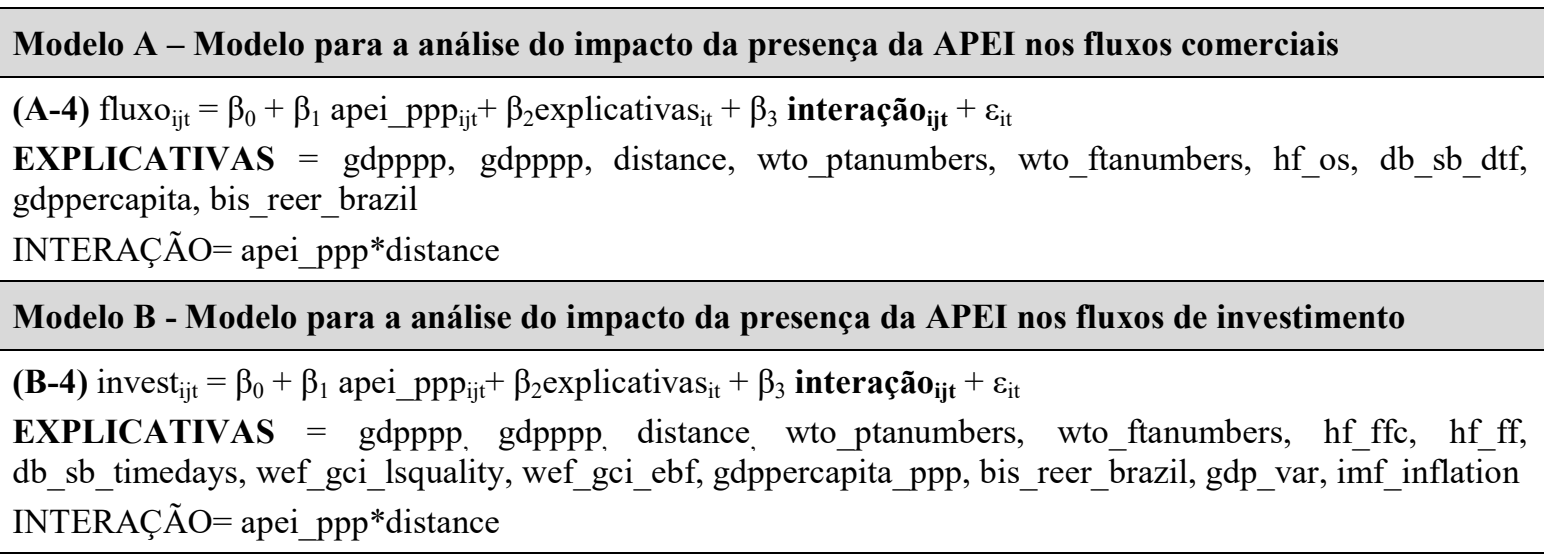

Figura 21 - Modelos com a variável de interação entre APEI e distância

Fonte: Elaborado pela autora 


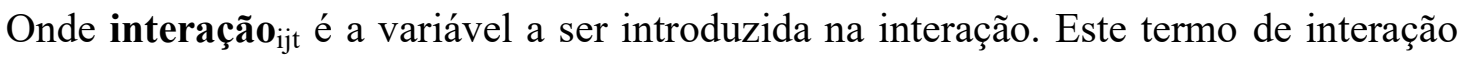
nos permite captar o efeito da APEI e sua variação em relação à distância.

Houve ainda a necessidade de modificar o modelo para que se avaliasse se a estrutura das agências apresenta efeitos sobre seu impacto. O modelo adaptado insere variáveis dicotomias que verificam a diferença no impacto da APEI. Logo, os modelos ficaram como na Figura 22:

Modelo A - Modelo para analise da estrutura da APEI no impacto sobre os fluxos comerciais

(A-5) fluxo ijt $_{\text {it }}=\beta_{0}+\beta_{1}$ apei_ppp ijt $_{\text {ijt }}+\beta_{2}$ explicativas $_{\mathrm{it}}+\beta_{3}$ apei_financiamento $_{\mathrm{ij}}+\varepsilon_{\mathrm{i}}$

(A-6) fluxo ijt $_{\mathrm{jt}}=\beta_{0}+\beta_{1}$ apei_ppp $\mathrm{ijt}_{\mathrm{jit}}+\beta_{2}$ explicativas $_{\mathrm{it}}+\beta_{3}$ apei_ef $\mathbf{f i j}_{\mathrm{ij}}+\varepsilon_{\mathrm{it}}$

(A-7) fluxo $_{\mathrm{ijt}}=\beta_{0}+\beta_{1}$ apei_ppp $_{\mathrm{ijt}}+\beta_{2}$ explicativas $_{\mathrm{it}}+\beta_{3}$ apei_autonomia $_{\mathrm{ij}}+\varepsilon_{\mathrm{it}}$

EXPLICATIVAS $=$ gdpppp, gdpppp, distance, wto_ptanumbers, wto_ftanumbers, hf_os, db_sb_dtf, gdppercapita, bis_reer_brazil

Modelo B - Modelo para analise da estrutura da APEI no impacto sobre os fluxos de investimento

(B-5) invest $_{\mathrm{ijt}}=\beta_{0}+\beta_{1}$ apei_ppp $\mathrm{pit}_{\mathrm{ijt}}+\beta_{2}$ explicativas $_{\mathrm{it}}+\beta_{3}$ apei_financiamento $_{\mathrm{ij}}+\varepsilon_{\mathrm{it}}$

(B-6) invest ijt $_{\mathrm{jt}}=\beta_{0}+\beta_{1}$ apei_ppp $\mathrm{ijjt}_{\mathrm{ij}}+\beta_{2}$ explicativas $_{\mathrm{it}}+\beta_{3}$ apei_ef $_{\mathrm{ijj}}+\varepsilon_{\mathrm{it}}$

(B-7) invest $t_{\mathrm{ijt}}=\beta_{0}+\beta_{1}$ apei_ppp $_{\mathrm{ijt}}+\beta_{2}$ explicativas $_{\mathrm{it}}+\beta_{3}$ apei_autonomia $_{\mathrm{ijj}}+\varepsilon_{\mathrm{it}}$

EXPLICATIVAS $=$ gdpppp, gdpppp, distance, wto_ptanumbers, wto_ftanumbers, hf_ffc, hf_ff, db_sb_timedays, wef_gci_lsquality, wef_gci_ebf, gdppercapita_ppp, bis_reer_brazil, gdp_var, inflation.

Figura 22 - Modelos modificado para a análise da estrutura da APEI no impacto sobre os fluxos

Fonte: Elaborado pela autora

Onde apei_financiamento é a variável que indica se a APEI é de capital público, privado ou parceria público-privada, apei_ef é a variável que indica se a APEI tem estrutura física própria ou se está localizada em um consulado do país de origem no país hospedeiro, e, apei_autonomia é a variável que indica se a APEI esta subordinada a um ministério do país ou direto a presidência.

\subsection{Seleção da Amostra e Coleta de Dados}

O foco nesta tese se dá sobre as agências de promoção de exportação e investimento (APEIs), em especial a avaliação do impacto da sua presença nos fluxos comerciais entre os países de origem e de destino das mesmas, bem como a identificação dos fatores que podem explicar a intensidade e direção destas reações.

A literatura existente que aborda questões de investigação semelhantes é bem pequena e geralmente se concentram em amostras cross-section, porém não temporal, ou com períodos 
bem curtos de tempo, além de restringir a análise a uma ou duas APEIs apenas (Wells \& Wint, 2000; Zanata, Camilo, Consoni, \& Varrichio, 2008; Hayakawa et al., 2010; Morisset; Andrews-Johnson, 2004; Hayakawa et al., 2014; Alvarez \& crespi, 2000; Martincus \& Carballo, 2008; Miskinis \& Byrka, 2014; Morisset, 2003).

A análise de painéis de dados tem sido utilizada em ciências sociais porque permite a análise cross sections e de períodos de tempo no mesmo modelo, o que aumenta o número de observações disponíveis, possibilitando melhores estimativas. Este estudo propõe-se a analisar o efeito das APEIs a partir das transações comerciais e de investimentos do Brasil com seus parceiros. A amostra foi determinada por um critério de acessibilidade, cobrindo todos os fluxos comerciais (exportação e importação) e de investimento (entrada e saída) entre o Brasil duzentos e vinte e quatro países no período de 1995 a 2015. Além disso, foram analisadas as APEIs com presença no mercado brasileiro e a agência brasileira, APEX-Brasil, para as quais foi realizado um levantamento do ano de entrada no país e tempo de atuação entre outros dados que serão apresentados adiante.

O painel de dados foi constituído com variáveis econômicas, institucionais e das APEIs. Os dados foram coletados a partir dos bancos de dados do MDIC, BID Banco Mundial, Heritage Foundation, Doing Business, Global Competitiveness Index, Quality of Goverment, CEPII, IMF, OECD, WTO e entrevistas telefônicas com as agências presentes no estudo. As Figuras 23 e 24 apresentam, respectivamente, os países com os quais o Brasil tem fluxos de investimento direto no exterior e fluxos de investimento.

\begin{tabular}{|c|c|c|}
\hline África do Sul & Eslovénia & Itália \\
\hline Alemanha & Espanha & Japão \\
\hline Arábia Saudita & Estados Unidos & Luxemburgo \\
\hline Argentina & Estónia & México \\
\hline Austrália & Finlândia & Noruega \\
\hline Áustria & França & Nova Zelândia \\
\hline Bélgica & Grécia & Polónia \\
\hline Brasil & Holanda & Portugal \\
\hline Canadá & Hungria & Reino Unido \\
\hline Chile & Índia & República Checa \\
\hline China & Indonésia & Rússia \\
\hline Coréia do Sul & Irlanda & Suécia \\
\hline Dinamarca & Islândia & Suíça \\
\hline Eslováquia & Israel & Turquia \\
\hline
\end{tabular}

Figura 23 - Países com fluxos de investimento com o Brasil

Fonte: Elaborado pela autora com base nos dados da OECD 


\begin{tabular}{|c|c|c|c|}
\hline Afeganistão & Cuba & Jordânia & Polinésia Francesa \\
\hline África do Sul & Dinamarca & Jugoslávia & Polônia \\
\hline Albânia & Djibuti & Kiribati & Porto Rico \\
\hline Alemanha & Dominica & Kuwait & Portugal \\
\hline Andorra & El Salvador & Laos & Quênia \\
\hline Angola & Emirados Árabes Unidos & Lebuan & Reino Unido \\
\hline Anguilla & Equador & Lesoto & República Checa \\
\hline Antígua e Barbuda & Eritréia & Letônia & $\begin{array}{c}\text { República Democrática } \\
\text { do Congo }\end{array}$ \\
\hline Antilhas Holandesas & Eslováquia & Líbano & República do Congo \\
\hline Arábia Saudita & Eslovênia & Libéria & $\begin{array}{l}\text { República do } \\
\text { Quirguizistão }\end{array}$ \\
\hline Argélia & Espanha & Líbia & República Dominicana \\
\hline Argentina & Estados Unidos & Liechtenstein & Reunião \\
\hline Armênia & Estônia & Lituânia & Romênia \\
\hline Aruba & Etiópia & Luxemburgo & Ruanda \\
\hline Austrália & Fiji & Macau & Rússia \\
\hline Áustria & Filipinas & Macedónia & Samoa \\
\hline Azerbaijão & Finlândia & Madagáscar & San Marino \\
\hline Bahamas & França & Madeira & Santa Lúcia \\
\hline Bahrain & Gabão & Malásia & São Cristóvão e Nevis \\
\hline Bangladesh & Gâmbia & Malavi & São Tomé e Príncipe \\
\hline Barbados & Gana & Maldivas & $\begin{array}{c}\text { São Vicente e } \\
\text { Granadinas }\end{array}$ \\
\hline Belarus & Geórgia & Mali & Senegal \\
\hline Bélgica & Gibraltar & Malta & Serra Leoa \\
\hline Belize & Grécia & Marianas do Norte & Sérvia \\
\hline Benin & Grenada & Marrocos & Seychelles \\
\hline Bermudas & Groenlândia & Martinique & Síria \\
\hline Bolívia & Guadalupe & Mauritânia & Somália \\
\hline Bósnia e Herzegovina & Guam & Mauritius & Sri Lanka \\
\hline Botswana & Guatemala & México & Sta. Helena \\
\hline Brasil & Guernsey & Micronésia & Sto. Kitts e Nevis \\
\hline Brunei Darussalam & Guiana & Moçambique & Sto. Pierre e Miquelon \\
\hline Bulgária & Guiana Francesa & Moldova & Suazilândia \\
\hline Burkina Faso & Guiné & Mônaco & Sudão \\
\hline Burundi & Guiné Equatorial & Mongólia & Suécia \\
\hline Butão & Guiné-Bissau & Montenegro & Suíça \\
\hline Cabo Verde & Haiti & Montserrat & Suriname \\
\hline Camarões & Holanda & Myanmar & Tailândia \\
\hline Camboja & Honduras & Namíbia & Taiwan \\
\hline Canadá & Hong Kong & Nauru & Tajiquistão \\
\hline
\end{tabular}

(Continua)

Figura 24 - Países com fluxos comerciais com o Brasil 


\begin{tabular}{|c|c|c|c|}
\hline Canadá & Hong Kong & Nauru & Tajiquistão \\
\hline Catar & Hungria & Nepal & Tanzânia \\
\hline Cazaquistão & Iémen & Nicarágua & Timor Leste \\
\hline República Central Africana & Ilhas Canárias & Níger & Tokelau \\
\hline Chade & Ilhas Cayman & Nigéria & Tonga \\
\hline Chile & Ilhas Marshall & Niue & Trinidad e Tobago \\
\hline China & Ilhas Salomão & Noruega & Tunísia \\
\hline Chipre & Índia & Nova Caledônia & Turquemenistão \\
\hline Cidade do Vaticano & Indonésia & Nova Zelândia & Tuvalu \\
\hline Cingapura & Irã & Omã & Ucrânia \\
\hline Colômbia & Iraque & Palau & Uganda \\
\hline Comores & Irlanda & Palestina & Uruguai \\
\hline Coréia & Islândia & Panamá & Uzbequistão \\
\hline Coreia do Norte & Israel & Papua Nova Guiné & Vanuatu \\
\hline Costa Rica & Itália & Paquistão & Venezuela \\
\hline Cote D'Ivore & Jamaica & Paraguai & Vietnã \\
\hline Croácia & Japão & Peru & Zâmbia \\
\hline & & & Zimbábue \\
\hline
\end{tabular}

(Conclusão)

\section{Figura 24 - Países com fluxos comerciais com o Brasil}

Fonte: Elaborado pela autora com base nos dados do MDIC

A Figura 25 apresenta a descrição das principais variáveis, que foram selecionadas através do procedimento stepwise para a constituição do modelo.

\begin{tabular}{|c|c|c|c|}
\hline Variáveis & Definições & Medidas & Fontes \\
\hline \multicolumn{4}{|c|}{ Dependentes } \\
\hline $\begin{array}{l}\text { Exportação } \\
\text { (export) }\end{array}$ & $\begin{array}{l}\text { Logaritmo do volume de exportação brasileira } \\
\text { para o país de destino }\end{array}$ & $\begin{array}{l}\text { Log (Milhões } \\
\text { de USD) }\end{array}$ & MDIC \\
\hline $\begin{array}{l}\text { Importação } \\
\text { (import) }\end{array}$ & $\begin{array}{l}\text { Logaritmo do volume de importação brasileira } \\
\text { do país de origem }\end{array}$ & $\begin{array}{l}\text { Log (Milhões } \\
\text { de USD) }\end{array}$ & MDIC \\
\hline $\begin{array}{l}\text { IDE saída } \\
\text { (loginvestout) }\end{array}$ & $\begin{array}{l}\text { Logaritmo do volume de IDE brasileiro para o } \\
\text { país de destino }\end{array}$ & Log (USD) & OECD \\
\hline $\begin{array}{l}\text { IDE entrada } \\
\text { (loginvestin) }\end{array}$ & $\begin{array}{l}\text { Logaritmo do volume de IDE recebido no } \\
\text { Brasil dos países de origem }\end{array}$ & Log (USD) & OECD \\
\hline
\end{tabular}

(Continua)

Figura 25 - Variáveis utilizadas no estudo 


\begin{tabular}{|c|c|c|c|}
\hline Variáveis & Definições & Medidas & Fontes \\
\hline \multicolumn{4}{|c|}{ Independentes } \\
\hline $\begin{array}{c}\text { Presença da APEX } \\
\text { em outros países } \\
\text { (apex_ppp) }\end{array}$ & $\begin{array}{l}\text { A APEI do país de origem do fluxo está } \\
\text { presente no país de destino do fluxo }\end{array}$ & $\begin{array}{l}\text { Sim (1) ou não } \\
(0)\end{array}$ & $\begin{array}{l}\text { Obtenção da } \\
\text { informação } \\
\text { através de sites e } \\
\text { contato direto } \\
\text { com as agências }\end{array}$ \\
\hline $\begin{array}{l}\text { Presença da } \\
\text { agência de outros } \\
\text { países no Brasil } \\
\text { (apei_br) }\end{array}$ & $\begin{array}{l}\text { A APEI do país de destino do fluxo está } \\
\text { presente no país de origem deste do fluxo }\end{array}$ & $\begin{array}{l}\text { Sim (1) ou não } \\
(0)\end{array}$ & $\begin{array}{l}\text { Obtenção da } \\
\text { informação } \\
\text { através de sites e } \\
\text { contato direto } \\
\text { com as agências }\end{array}$ \\
\hline $\begin{array}{l}\text { Tempo de } \\
\text { presença da APEI } \\
\text { no país de destino } \\
\quad \text { (apex_pppa) }\end{array}$ & Tempo de presença da APEI no país destino & $\#$ anos & $\begin{array}{l}\text { Contato direto } \\
\text { com as agências }\end{array}$ \\
\hline $\begin{array}{l}\text { Logarítimo do } \\
\text { tempo de presença } \\
\text { da APEI no país de } \\
\text { destino } \\
\text { (apei_pppa_log) }\end{array}$ & $\begin{array}{l}\text { Logaritmo do tempo de presença da APEI no } \\
\text { país destino }\end{array}$ & $\begin{array}{l}\text { Logaritmo } \\
\quad \text { (anos) }\end{array}$ & $\begin{array}{l}\text { Contato direto } \\
\text { com as agências }\end{array}$ \\
\hline $\begin{array}{l}\text { Distância } \\
\text { geográfica } \\
\text { (distance) }\end{array}$ & $\begin{array}{l}\text { Logaritmo da distância geográfica em km entre } \\
\text { os países }\end{array}$ & $\log (\mathrm{Km})$ & $\begin{array}{l}\text { CEPII (disponível } \\
\text { em } \\
\text { http://www.cepii.fr } \\
\text { /anglaisgraph/bdd/ } \\
\text { distances.htm.). }\end{array}$ \\
\hline $\begin{array}{l}\text { PIB do país de } \\
\text { origem } \\
\text { (gdpppp_o) }\end{array}$ & $\begin{array}{c}\text { Indicador do tamanho da economia de origem } \\
\text { do fluxo (Gross domestic product based on } \\
\text { purchasing-power-parity }{ }^{2} \text { (PPP) valuation of } \\
\text { country GDP) }\end{array}$ & Bilhões USD & \begin{tabular}{|} 
World Bank, \\
International \\
Comparison \\
Program database
\end{tabular} \\
\hline $\begin{array}{l}\text { PIB do país de } \\
\text { destino } \\
\text { (gdpppp_d) }\end{array}$ & $\begin{array}{c}\text { Indicador do tamanho da economia de destino } \\
\text { do fluxo (Gross domestic product based on } \\
\text { purchasing-power-parity (PPP) valuation of } \\
\text { country GDP) }\end{array}$ & Bilhões USD & $\begin{array}{l}\text { World Bank, } \\
\text { International } \\
\text { Comparison } \\
\text { Program } \\
\text { database }\end{array}$ \\
\hline $\begin{array}{l}\text { Demanda efetiva } \\
\text { gdppercapita_ppp }\end{array}$ & $\begin{array}{l}\text { PIB per capita - PIB per capita baseado no PPP } \\
\text { (purchasing power parity) }\end{array}$ & & $\begin{array}{c}\text { World Bank, } \\
\text { International } \\
\text { Comparison } \\
\text { Program } \\
\text { database }\end{array}$ \\
\hline
\end{tabular}

(Continuação)

\section{Figura 25 - Variáveis utilizadas no estudo}

2 O fator de conversão da paridade do poder de compra (ppp) é o número de unidades da moeda de um país necessário para comprar a mesma quantidade de bens e serviços em dólares americanos no mercado interno dos Estados Unidos. 


\begin{tabular}{|c|c|c|c|}
\hline Variáveis & Definições & Medidas & Fontes \\
\hline $\begin{array}{l}\text { Liberdade } \\
\text { Econômica } \\
\text { (hf_os) }\end{array}$ & $\begin{array}{l}\text { Esta variável representa a qualidade de } \\
\text { instituições domésticas de países hospedeiros. } \\
\text { É esperado que nos mercados hospedeiros } \\
\text { existam características de liberdade econômica } \\
\text { atraindo níveis maiores de investimento. O } \\
\text { Índice da Liberdade Econômica é composto } \\
\text { por dez itens: Liberdade de negócios, livre } \\
\text { comércio, liberdade fiscal, liberdade monetária, } \\
\text { investimentos governamentais, liberdade } \\
\text { financeira, direitos de propriedade, liberdade } \\
\text { de corrupção e liberdade sindical e controle de } \\
\text { gastos públicos. }\end{array}$ & $\begin{array}{c}\text { Pontuação de } 0 \\
\text { a } 100\end{array}$ & Heritage Index \\
\hline $\begin{array}{l}\text { Acordos de livre } \\
\text { comércio } \\
\text { (wto_fta) }\end{array}$ & $\begin{array}{l}\text { Esta variável expressa o envolvimento do país } \\
\text { receptor do investimento em projetos de } \\
\text { integração regional ou algum tipo de acordo de } \\
\text { livre comércio. }\end{array}$ & $\begin{array}{l}\text { Sim (1) ou não } \\
(0)\end{array}$ & WTO \\
\hline $\begin{array}{l}\text { Acordos } \\
\text { preferenciais } \\
\text { (wto_pta) }\end{array}$ & $\begin{array}{l}\text { Esta variável expressa o envolvimento do país } \\
\text { receptor do investimento em projetos de } \\
\text { integração regional ou algum tipo de acordo de } \\
\text { livre comércio. }\end{array}$ & $\begin{array}{l}\text { Sim (1) ou não } \\
(0)\end{array}$ & WTO \\
\hline $\begin{array}{l}\text { Abertura } \\
\text { Comercial } \\
\text { (db_tab_dtf) }\end{array}$ & $\begin{array}{l}\text { O Doing Business compila os requisitos } \\
\text { procedimentais para exportação e importação } \\
\text { de uma carga padronizada de mercadorias por } \\
\text { transporte marítimo. O tempo e o custo } \\
\text { necessários para completar } 4 \text { etapas pré- } \\
\text { definidas (preparação de documentos; liberação } \\
\text { alfandegária e outras inspeções; transporte } \\
\text { terrestre; e movimentação e manuseio no porto } \\
\text { e no terminal)para exportação e importação de } \\
\text { mercadorias são registrados, mas o tempo e o } \\
\text { custo do transporte marítimo não são incluídos } \\
\text { Todos os documentos necessários ao } \\
\text { comerciante para exportar ou importar as } \\
\text { mercadorias entre fronteiras também são } \\
\text { registrados. }\end{array}$ & $\begin{array}{c}\text { Pontuação de } 0 \\
\text { a } 100\end{array}$ & $\begin{array}{l}\text { Doing Business } \\
\quad \text { Indicators } \\
\text { compiled by the } \\
\text { World Bank }\end{array}$ \\
\hline $\begin{array}{l}\text { Estabilidade } \\
\text { econômica } \\
\text { (bis_reer) }\end{array}$ & $\begin{array}{l}\text { Taxa de câmbio real (calculada a partir da taxa } \\
\text { de câmbio nominal bilateral do país doméstico } \\
\text { em relação aos EUA, em moeda local por } \\
\text { US\$). }\end{array}$ & & $\begin{array}{c}\text { Bankfor } \\
\text { International } \\
\text { Settlements. BIS } \\
\text { Statistics } \\
\text { Explorer. } \\
\text { Disponível em: } \\
\text { http://stats.bis.or } \\
\text { g/statx/srs/table/i } \\
2\end{array}$ \\
\hline
\end{tabular}

(Continuação)

Figura 25 - Variáveis utilizadas no estudo 


\begin{tabular}{|c|c|c|c|}
\hline Variáveis & Definições & Medidas & Fontes \\
\hline $\begin{array}{l}\text { Possibilidade de } \\
\text { Corrupção } \\
\text { (hf_ffc) }\end{array}$ & $\begin{array}{l}\text { Esta variável analisa as incertezas nas relações } \\
\text { econômicas. A corrupção é definida como } \\
\text { desonestidade ou decadência. No contexto de } \\
\text { governança, pode ser definida como a falência } \\
\text { de integridade do sistema, uma distorção pelos } \\
\text { quais indivíduos podem ganhar pessoalmente à } \\
\text { custa dos outros. A corrupção política é } \\
\text { manifestada propriamente em muitas formas } \\
\text { como suborno, extorsão, nepotismo, patrocínio, } \\
\text { desfalque, e (mais comumente) enxerto, por } \\
\text { meio de órgãos oficiais públicos que roubam } \\
\text { ou lucram ilegitimamente de capitais públicos. } \\
\text { Quanto maior a nota, maior a "liberdade" de } \\
\text { corrupção do país. }\end{array}$ & $\begin{array}{c}\text { Pontuação de } 0 \\
\text { a } 100\end{array}$ & Heritage Index \\
\hline $\begin{array}{l}\text { Inicialização de } \\
\text { Negócio } \\
\text { (db_sb_timedays) }\end{array}$ & $\begin{array}{l}\text { Essa variável analisa a facilidade de entrada no } \\
\text { mercado. A medida registra a duração média } \\
\text { que os advogados societários indicam ser } \\
\text { necessária, na prática, para concluir um } \\
\text { procedimento com acompanhamento mínimo } \\
\text { com órgãos do governo e nenhum pagamento } \\
\text { extra. Todos os procedimentos que são } \\
\text { oficialmente exigidos para um empresário } \\
\text { começar as atividades e formalmente funcionar } \\
\text { os negócios industriais ou comerciais. Estes } \\
\text { incluem obter todas as licenças e permissões } \\
\text { necessárias e completando quaisquer } \\
\text { notificações exigidas, verificações as devidas } \\
\text { inscrições para a empresa e empregados com } \\
\text { citações relevantes. }\end{array}$ & \# dias & $\begin{array}{l}\text { Doing Business } \\
\text { Indicators } \\
\text { compiled by the } \\
\text { World Bank }\end{array}$ \\
\hline $\begin{array}{l}\text { Busca por novos } \\
\text { fornecedores } \\
\text { (wef_gci_lsquality) }\end{array}$ & Qualidade de fornecedores locais & nota de 1 a 7 & $\begin{array}{l}\text { Global } \\
\text { Competitiveness } \\
\text { Index-World } \\
\text { Economic Forum }\end{array}$ \\
\hline $\begin{array}{l}\text { Risco de Mercado } \\
\text { (wef_gci_ebf) }\end{array}$ & Comportamento ético das firmas & nota de 1 a 7 & $\begin{array}{l}\text { Global } \\
\text { Competitiveness } \\
\text { Index - World } \\
\text { Economic Forum }\end{array}$ \\
\hline $\begin{array}{l}\text { Crescimento do } \\
\text { mercado } \\
\text { (gdp_var) }\end{array}$ & Variação do PIB (\%) & $\%$ & $\begin{array}{l}\text { World Economic } \\
\text { Outlook-World } \\
\quad \text { Bank }\end{array}$ \\
\hline $\begin{array}{l}\text { Instabilidade } \\
\text { econômica } \\
\text { (inflation) }\end{array}$ & $\begin{array}{l}\text { Inflação no país receptor do investimento (em } \\
\text { variação\% ao ano). }\end{array}$ & $\%$ ao ano & IMF \\
\hline $\begin{array}{l}\text { Controle societário da } \\
\text { APEI } \\
\text { (apei_financiamento) }\end{array}$ & $\begin{array}{l}\text { Indica se a APEI tem financiamento publico } \\
\text { (1), privado (2), ou por parceria publico- } \\
\text { privada (3). }\end{array}$ & $\begin{array}{c}\text { Classificação } \\
\text { com a } \\
\text { numeração de } 1 \\
\text { a } 3\end{array}$ & $\begin{array}{c}\text { Obtenção da } \\
\text { informação através } \\
\text { de sites e contato } \\
\text { direto com as } \\
\text { agências }\end{array}$ \\
\hline
\end{tabular}

(Continuação)

\section{Figura 25 - Variáveis utilizadas no estudo}




\begin{tabular}{|c|l|c|c|}
\hline Variáveis & \multicolumn{1}{|c|}{ Definições } & Medidas & Fontes \\
\hline $\begin{array}{c}\text { Autonomia da } \\
\text { APEI (apei_ef) }\end{array}$ & $\begin{array}{l}\text { Indica se a APEI tem estrutura física dentro de } \\
\text { consulado (1) ou em escritório próprio (2). }\end{array}$ & $\begin{array}{c}\text { Classificação } \\
\text { com a } \\
\text { numeração 1 e } \\
2\end{array}$ & $\begin{array}{c}\text { Obtenção da } \\
\text { informação } \\
\text { através de sites e } \\
\text { contato direto } \\
\text { com as agências }\end{array}$ \\
\hline $\begin{array}{c}\text { Subordinação da } \\
\text { APEI }\end{array}$ & $\begin{array}{l}\text { Indica se a APEI reporta-se a presidência (1) } \\
\text { ou um ministério (2). }\end{array}$ & $\begin{array}{c}\text { Classificação } \\
\text { com a }\end{array}$ & $\begin{array}{c}\text { Obtenção da } \\
\text { informação através } \\
\text { de sites e contato } \\
\text { direto com as } \\
\text { agências }\end{array}$ \\
\hline $\begin{array}{c}\text { apei_autonomia) } \\
\text { Distancia Cultural } \\
\text { (cdist_berry) }\end{array}$ & $\begin{array}{l}\text { Distância cultural entre o país de origem e o } \\
\text { país de destino, medido pelo método de } \\
\text { Mahalanobis, de acordo com Berry et al. } \\
\text { (2010), que compreende quatro dimensões } \\
\text { (Hofstede):a distância do poder, } \\
\text { individualismo, masculinidade/feminilidade e } \\
\text { aversão à incerteza. }\end{array}$ & $\begin{array}{c}\text { Pontuação de 0 } \\
\text { a 124 }\end{array}$ & $\begin{array}{c}\text { Debsite dos autores: } \\
\text { disponibilizados no } \\
\text { http://lauder.wharton } \\
\text {.upenn.edu/ciber/fac } \\
\text { ulty_research.asp }\end{array}$ \\
\hline
\end{tabular}

(Conclusão)

\section{Figura 25 - Variáveis utilizadas no estudo}

Fonte: Elaborado pela autora 
144 


\section{RESULTADOS}

Este capítulo fará uma apresentação dos resultados obtidos nesta pesquisa. Conforme observado na Figura 26, foram levantados dados de 19 agências atuantes no Brasil. Foram selecionadas agências de promoção de países e não de regiões ou estados.

\begin{tabular}{|c|c|c|}
\hline País & APEI & $\begin{array}{c}\text { Ano entrada } \\
\text { Brasil }\end{array}$ \\
\hline Austrália & Austrade & 1993 \\
\hline Chile & Prochile & 1978 \\
\hline Colômbia & Procolombia & 2012 \\
\hline República Tcheca & Czech Trade & 2006 \\
\hline Equador & Proecuador & 2009 \\
\hline Espanha & ICEX & 1996 \\
\hline França & UBIFRANCE - Business France & 2015 \\
\hline Alemanha & BTAI - GTAI & 1997 \\
\hline Irlanda & IDA Ireland & 2009 \\
\hline Israel & Invest in Israel & 2005 \\
\hline Itália & Italian Trade Promotion Agency & 1964 \\
\hline Japão & Jetro & 1972 \\
\hline Coréia do Sul & Kotra & 1960 \\
\hline México & Promexico & 2008 \\
\hline Holanda & NFIA Brazil & 2012 \\
\hline Nova Zelândia & New Zealend Trade and Investment & 1999 \\
\hline Portugal & AICEP Portugal Global & 2007 \\
\hline Suíça & Switzerland Global Enterprise & 2013 \\
\hline Reino Unido & Uktrade & 2003 \\
\hline
\end{tabular}

Figura 26 - APEIs com presença no Brasil selecionadas para participar do estudo

Fonte: Elaborado pela autora

A Figura 27 identifica os países com presença da APEX Brasil, bem como o respectivo ano de entrada e de eventual, saída do mesmo. 


\begin{tabular}{|c|c|c|}
\hline País hospedeiro & $\begin{array}{c}\text { Ano de } \\
\text { entrada }\end{array}$ & $\begin{array}{c}\text { Ano de } \\
\text { saída }\end{array}$ \\
\hline Cuba & 2008 & \\
\hline Colômbia & 2013 & \\
\hline Rússia & 2010 & \\
\hline Bélgica & 2010 & \\
\hline Angola & 2011 & \\
\hline China & 2010 & \\
\hline Alemanha & 2005 & 2011 \\
\hline Polônia & 2005 & 2011 \\
\hline Portugal & 2005 & 2011 \\
\hline Emirados Árabes Unidos & 2006 & \\
\hline Estados Unidos & 2005 & \\
\hline
\end{tabular}

Figura 27 - Países com presença da APEX Brasil

Fonte: Elaborado pela autora

A Tabela 1 apresenta a estatística descritiva das variáveis

Tabela 1 - Estatística descritiva das variáveis

(continua)

\begin{tabular}{cccccc}
\hline Variáveis & Obs. & Média & Desvio Padrão & Min. & Máx. \\
\hline Import & 4114 & 13.8634 & 6.1608 & 0 & 24.343 \\
Export & 3973 & 16.3269 & 4.5955 & 0 & 24.552 \\
Loginvestout & 4729 & 3.6252 & 0.1989 & -1.179 & 5.890 \\
Loginvestin & 4785 & 3.5059 & 0.1965 & -1.110 & 5.619 \\
apex_ppp & 4880 & 0.0154 & 0.1230 & 0 & 1 \\
apei_br & 4880 & 0.0414 & 0.1992 & 0 & 1 \\
apex_pppa_ g & 4880 & 0.0083 & 0.0758 & 0 & 1.041 \\
apei_br_a_ g & 4880 & 0.0341 & 0.1813 & 0 & 1.322 \\
apei_finan 2 & 4880 & 84.3857 & 17.3970 & 0 & 88 \\
apei_ef2 & 4880 & 84.4066 & 17.2957 & 0 & 88 \\
apei_auton 2 & 202 & 1.8911 & 0.4550 & 0 & 2 \\
hf_os & 3264 & 59.5975 & 11.8815 & 0 & 90.5 \\
hf_ffc & 3282 & 41.3793 & 23.3147 & 0 & 100 \\
hf_ff & 3272 & 71.9227 & 16.0014 & 0 & 99.9 \\
db_tab_dtf & 1726 & 63.9780 & 22.8216 & 0 & 100 \\
db_sb_dtf & 2006 & 72.3523 & 19.5895 & 0 & 99.96 \\
db_sb_time $\sim \mathrm{s}$ & 2006 & 34.9444 & 52.7189 & 0 & 697 \\
wto_ptanum $\sim \mathrm{s}$ & 4880 & 0.3230 & 0.7777 & 0 & 5 \\
wto_ftanum $\sim \mathrm{s}$ & 4880 & 0.0115 & 0.1065 & 0 & 1 \\
bis_reer_b 1 & 4740 & 81.2112 & 16.0562 & 53.7342 & 104.6108 \\
wef_gci_ebf & 1370 & 3.8715 & 1.4933 & 0 & 6.7781 \\
\hline
\end{tabular}


Tabela 1 - Estatística descritiva das variáveis

\begin{tabular}{cccccc}
\hline Variáveis & Obs & Média & Desvio Padrão & Min. & Máx. \\
\hline wef_gc $\sim$ ality & 1370 & 4.0991 & 1.4548 & 0 & 6.5375 \\
Gdppppbr & 4880 & 14.2762 & 0.3224 & 13.5787 & 14.7776 \\
Gdpppp & 3990 & 10.1905 & 3.1801 & 0 & 16.7260 \\
gdppercapi $\sim p$ & 3679 & 8.8840 & 1.2363 & 5.6008 & 11.8540 \\
gdp_var & 3822 & 4.6655 & 76.9186 & -1.00 & 2542.155 \\
Inflation & 3688 & 11.2980 & 89.7856 & -72.72 & 4146.01 \\
inflation_br & 4700 & 9.4018 & 12.9719 & 3.19 & 66 \\
gdppercapi $\sim$ r & 9391 & 5362.47 & 5884.627 & 8.8017 & 15838.02 \\
Distance & 4502 & 9.0716 & 0.5023 & 7.0016 & 9.8428 \\
cdis_hof & 1808 & 1.9277 & 0.8462 & 0 & 4.3344 \\
cdist_mahala & 2074 & 12.1985 & 14.4120 & 0.32 & 123.59 \\
\hline
\end{tabular}

Fonte: Elaborado pela autora

As próximas seções deste capítulo apresentaram os resultados do modelo de painel dinâmico para a verificação das hipóteses levantadas neste estudo.

\subsection{Impacto da presença da APEI sobre os fluxos do país de origem para o país hospedeiro da agência}

O resultado do modelo de painel dinâmico para a análise do impacto da presença da APEI sobre os fluxos do país de origem para o país hospedeiro da agência (H1a) se encontra na Tabela 2. Os modelos de I a IV representam, na ordem, exportação, importação, saída de IDE e entrada de IDE. As variáveis apex_ppp e apei_br avaliam, respectivamente, a presença da APEX em países hospedeiros e a presença de agências de diferentes países no Brasil. Como pode ser observado na Tabela 2, a variável apex_ppp foi utilizada nos fluxos de saída do Brasil, logo, exportação (modelo I) e saída de IDE (modelo III), enquanto a variável apei_br aparece nos fluxos de importação (modelo II) e entrada de IDE (modelo IV).

É importante destacar que algumas variáveis aparecem apenas nos modelos de fluxos comerciais (I e III), enquanto outras nos fluxos de investimentos (II e IV). Isso porque em cada modelo foram consideradas as características institucionais relevantes para cada uma das situações, conforme o levantamento teórico.

Devido à diferença no número de observações de cada caso, ou mesmo por causa do número significativo de dados ausentes em um ou outro modelo, nota-se que o valor das observações dos modelos é diferente. 
Um número considerável de aspectos pode ser observado em cada modelo. Primeiramente, a variável de presença de acordos preferenciais (wto_ptanumbers) mostrou-se estatisticamente significante para os modelos de exportação (I), importação (II) e saída de IDE (III), enquanto a variável de acordo de livre comércio (wto_ftanumbers), não foi significante para nenhum dos casos.

Tabela 2 - Modelos de painéis dinâmicos para a presença da agência do país de origem no país hospedeiro sobre os fluxos do país de origem para o país hospedeiro

\begin{tabular}{|c|c|c|c|c|c|c|c|c|c|c|c|c|}
\hline \multirow[b]{3}{*}{ apex_ppp } & \multicolumn{3}{|c|}{$\begin{array}{c}\text { I } \\
\text { Exportação }\end{array}$} & \multicolumn{3}{|c|}{$\begin{array}{c}\text { II } \\
\text { Importação }\end{array}$} & \multicolumn{3}{|c|}{$\begin{array}{c}\text { III } \\
\text { IDE saída }\end{array}$} & \multicolumn{3}{|c|}{$\begin{array}{c}\text { IV } \\
\text { IDE entrada }\end{array}$} \\
\hline & \multicolumn{2}{|c|}{ Coef. } & \multirow{2}{*}{$\frac{\mathrm{SD}^{1}}{0.059}$} & \multicolumn{2}{|l|}{ Coef. } & \multirow[t]{2}{*}{$\mathrm{SD}^{1}$} & \multicolumn{2}{|c|}{ Coef. } & \multirow{2}{*}{$\frac{\mathrm{SD}^{1}}{0.128}$} & \multicolumn{2}{|c|}{ Coef. } & \multirow[t]{2}{*}{$\mathrm{SD}^{1}$} \\
\hline & 0.158 & $* * *$ & & & & & -0.088 & & & & & \\
\hline apei_br & & & & 0.518 & $*$ & 0.310 & & & & 0.118 & & 0.073 \\
\hline L.export & 0.855 & $* * *$ & 0.024 & & & & & & & & & \\
\hline L.import & & & & 0.208 & $*$ & 0.106 & & & & & & \\
\hline L.loginvestout & & & & & & & 0.265 & $*$ & 0.137 & & & \\
\hline L.loginvestin & & & & & & & & & & 0.198 & $* *$ & 0.065 \\
\hline wto_ptanumbers & 0.106 & $* * *$ & 0.028 & 0.779 & $* * *$ & 0.196 & -0.027 & $* *$ & 0.013 & -0.016 & & 0.015 \\
\hline wto_ftanumbers & 0.015 & & 0.074 & 1228 & & 0.897 & -0.012 & & 0.029 & 0.021 & & 0.037 \\
\hline hf_os & 0.003 & & 0.003 & -0.008 & & 0.026 & & & & & & \\
\hline db_tab_dtf & 0.005 & $* * *$ & 0.001 & 0.010 & & 0.013 & & & & & & \\
\hline $\mathrm{db} \_\mathrm{sb} \_\mathrm{dtf}$ & & & & & & & 0.000 & & 0.001 & 0.001 & & 0.001 \\
\hline hf_ffc & & & & & & & 0.004 & $* * *$ & 0.001 & 0.003 & $* * *$ & 0.001 \\
\hline hf_ff & & & & & & & -0.003 & $* * *$ & 0.001 & -0.002 & $*$ & 0.001 \\
\hline db_sb_timedays & & & & & & & 0.000 & $*$ & 0.000 & 0.000 & & 0.000 \\
\hline wef_gci_lsquality & & & & & & & 0.035 & $* *$ & 0.018 & 0.002 & & 0.017 \\
\hline wef_gci_ebf & & & & & & & -0.031 & $*$ & 0.016 & -0.001 & & 0.016 \\
\hline gdpppp_o & 0.131 & $* *$ & 0.054 & 0.572 & $* * *$ & 0.140 & 0.224 & $* * *$ & 0.044 & 0.022 & $*$ & 0.011 \\
\hline gdpppp_d & 0.066 & $* * *$ & 0.020 & -0.326 & & 0.305 & 0.027 & $* *$ & 0.012 & 0.262 & $* * *$ & 0.028 \\
\hline gdppercapita_ppp & 0.097 & $* * *$ & 0.033 & 1.499 & $* * *$ & 0.337 & -0.009 & & 0.013 & 0.000 & & 0.000 \\
\hline bis_reer_brazil & 0.001 & & 0.002 & -0.006 & & 0.013 & -0.004 & $* * *$ & 0.001 & -0.007 & $* *$ & 0.003 \\
\hline Distance & 0.089 & & 0.066 & -0.271 & & 0.440 & -0.032 & & 0.028 & -0.029 & & 0.027 \\
\hline gdp_var & & & & & & & -0.150 & & 0.118 & -3.500 & & 3.054 \\
\hline Inflation & & & & & & & 0.000 & & 0.000 & -0.006 & & 0.058 \\
\hline _cons & 0.000 & & 0.000 & 0.000 & & 0.000 & 0.000 & & 0.000 & 0.000 & & 0.000 \\
\hline $\mathrm{AB}$ test $\mathrm{AR}(1)$ & 0.041 & & & 0.000 & & & 0.038 & & & 0.093 & & \\
\hline $\mathrm{AB}$ test $\mathrm{AR}(2)$ & 0.114 & & & 0.169 & & & 0.187 & & & 0.679 & & \\
\hline R-square robust & 0.924 & & & 0.712 & & & 0.543 & & & 0.322 & & \\
\hline Observações & 1.208 & & & 1.288 & & & 1.028 & & & 1.038 & & \\
\hline
\end{tabular}

${ }^{*} \mathrm{p}<0.1 ; * * \mathrm{p}<0.05 ; * * * \mathrm{p}<0.01$

${ }^{1}$ Erro padrão robusto

Fonte: Elaborado pela autora

As variáveis de tamanho de mercado (gdpppp_o e gdpppp_d) foram significativas para os quatro modelos e com o sinal esperado, com exceção do coeficiente da variável de 
tamanho do mercado do país destino (gdpppp_d) no modelo de importação, que além de não ser significativa, deu o sinal contrário ao esperado. A demanda do país de destino (gdppercapita_ppp) foi significante nos fluxos comerciais e não significante nos fluxos de investimento. Outro aspecto desta variável foi o sinal positivo, como esperado, nos fluxos comerciais, porém negativo, mesmo que muito pequeno, nos fluxos de investimento.

Já a variável de câmbio (bis_reer_brazil) mostrou-se significante apenas para os fluxos de investimentos (modelos III e IV). Enquanto a variável de distância geográfica (distance), que mostrou o sinal esperado (negativo) nos quatro modelos, não foi significativa em nenhum deles.

Nos modelos de fluxos comerciais, entre as variáveis de impacto do ambiente institucional (hf_os, db_tab_dtf), apenas a variável db_tab_dtf, que indica a facilidade de se fazer comércio com o país, mostrou-se significativa no caso do modelo de exportação e nenhuma delas foi significativa no modelo de importação. Mesmo não parecendo significativa para a importação, a variável apresenta o sinal esperado (positivo) nos dois modelos, o que indica que quanto maior a facilidade de se fazer comércio com o país, maior será o fluxo comercial entre os países envolvidos. Apesar de não se mostrar significante e o coeficiente ser muito baixo tanto na exportação quanto na importação, o sinal da variável hf_os foi contrário ao esperado.

$\mathrm{Na}$ análise das variáveis institucionais no modelo de saída de IDE, nota-se que, com exceção da variável db_sb_dtf, que indica a dificuldade de iniciar um novo negócio no país, todas as demais - hf_ffc, hf_ff, db_sb_timedays, wef_gci_lsquality e wef_gci_ebf - foram significativas. Já no caso da entrada de IDE, apenas as variáveis hf_ffc e hf_ff foram significativas.

Conforme esperado, os sinais das variáveis hf_ffc (liberdade de corrupção) e wef_gci_lsquality (qualidade dos fornecedores) foram positivos. Entretanto, contrario às expectativas, os sinais das variáveis hf_ff (liberdade fiscal) e wef_gci_ebf (comportamento ético das firmas) foram negativos.

Os modelos nesta pesquisa apresentam erros padrões robustos à heterocedasticidade.

Conforme os resultados apresentados na Tabela 2, as agências aparecem como significativas nos fluxos comerciais (modelos I e II), mas não significativas nos fluxos de investimentos (modelos III e IV). No modelo I (exportação) a variável de presença da agência mostrou-se estatisticamente significante com um $\mathrm{p}<0.01$. Outro resultado importante dessas variáveis é que nos modelos de exportação (I), importação (II) e entrada de IDE (IV) o sinal 
do coeficiente foi como esperado, positivo, o que indica que as agências impactam positivamente sobre os fluxos comerciais e de entrada de IDE no Brasil.

A Figura 28 apresenta o resultado do teste da hipótese H1a para cada um dos modelos.

\begin{tabular}{|l|l|l|}
\hline \multicolumn{1}{|c|}{ Fluxo } & \multicolumn{1}{|c|}{ Hipóteses } & \multicolumn{1}{c|}{ Resultados } \\
\hline $\begin{array}{l}\text { Exportação } \\
\text { (H1aI) }\end{array}$ & $\begin{array}{l}\text { A presença da APEX no país hospedeiro aumenta o fluxo de exportação do } \\
\text { Brasil para o país hospedeiro. }\end{array}$ & Aceita \\
\hline $\begin{array}{l}\text { Importação } \\
\text { (H1aII) }\end{array}$ & $\begin{array}{l}\text { A presença da APEI do país de origem no Brasil aumenta o fluxo de } \\
\text { importação do Brasil do país de origem. }\end{array}$ & Aceita \\
\hline $\begin{array}{l}\text { IDE saída } \\
\text { (H1aIII) }\end{array}$ & $\begin{array}{l}\text { A presença da APEX no país hospedeiro aumenta o fluxo de IDE } \\
\text { brasileiro no país hospedeiro. }\end{array}$ & Rejeitada \\
\hline $\begin{array}{l}\text { IDE entrada } \\
\text { (H1aIV) }\end{array}$ & $\begin{array}{l}\text { A presença da APEI do país de origem no Brasil aumenta o fluxo de IDE } \\
\text { do país de origem no Brasil. }\end{array}$ & Rejeitada \\
\hline
\end{tabular}

\section{Figura 28 - Resultado para a hipótese H1a}

Fonte: Elaborado pela autora

\subsection{Impacto da presença da APEI sobre os fluxos do país hospedeiro para o país de origem da agência}

A Tabela 3 apresenta o resultado do modelo de painel dinâmico para a análise do impacto da presença da APEI sobre os fluxos do país hospedeiro para o país de origem da agência $(H 1 b)$. Os modelos de V a VIII representam, na ordem, exportação, importação, saída de IDE e entrada de IDE. Ao contrario do teste da hipótese H1a, a variável apex_ppp foi utilizada nos fluxos de entrada no Brasil, logo, importação (modelo VI) e entrada de IDE (modelo VIII), enquanto a variável apei_br aparece nos fluxos de exportação (modelo V) e saída de IDE (modelo VII).

As variáveis testadas foram as mesmas do que nos modelos de I a IV, apenas com a variação das agências testadas em cada caso. Com isso, a análise mais detalhada será realizada apenas quando houver resultados diferentes ao dos modelos testados anteriormente.

Essa diferença ocorre na significância das variáveis institucionais nos fluxos de investimentos (modelos VII e VIII). Para o modelo VII, de saída de IDE, as variáveis db_sb_timedays, wef_gci_lsquality e wef_gci_ebf, diferentemente do modelo III, não foram significativas. Já no modelo VIII, a variável db_sb_timedays, passou a ser significativa.

Conforme os resultados apresentados na tabela 3, as agências aparecem como significativas nos fluxos de importação (modelos VI) e de saída de IDE (modelo VII), mas não significativas nos fluxos de exportação (modelo V) e entrada de IDE (modelos VIII). Nos modelos de exportação (V), importação (VI) e saída de IDE (VII) o sinal do coeficiente foi 
como esperado, positivo. Contudo, no modelo de entrada de IDE (VIII), o sinal do coeficiente foi negativo.

A Figura 29 apresenta o resultado do teste da hipótese H1b para cada um dos modelos.

\begin{tabular}{|l|l|l|}
\hline \multicolumn{1}{|c|}{ Fluxo } & \multicolumn{1}{c|}{ Hipóteses } & \multicolumn{1}{c|}{ Resultados } \\
\hline $\begin{array}{l}\text { Exportação } \\
\text { (H1bI) }\end{array}$ & $\begin{array}{l}\text { A presença da APEI do país de destino do fluxo no Brasil aumenta o } \\
\text { fluxo de exportação do Brasil para o país de destino. }\end{array}$ & Rejeitada. \\
\hline $\begin{array}{l}\text { Importação } \\
\text { (H1bII) }\end{array}$ & $\begin{array}{l}\text { A presença da APEX no país de origem do fluxo aumenta o fluxo de } \\
\text { importação do Brasil deste país. }\end{array}$ & Aceita. \\
\hline $\begin{array}{l}\text { IDE saída } \\
\text { (H1bIII) }\end{array}$ & $\begin{array}{l}\text { A presença da APEI do país de destino do fluxo no Brasil aumenta o } \\
\text { fluxo de IDE do Brasil para o país de destino. }\end{array}$ & Aceita. \\
\hline $\begin{array}{l}\text { IDE entrada } \\
\text { (H1bIV) }\end{array}$ & $\begin{array}{l}\text { A presença da APEX no país de origem do fluxo aumenta o fluxo de IDE } \\
\text { do país de origem para o Brasil. }\end{array}$ & Rejeitada. \\
\hline
\end{tabular}

\section{Figura 29 - Resultado para a hipótese H1b}

Fonte: Elaborado pela autora

Tabela 3 - Modelos de painéis dinâmicos para a presença da agência do país de origem no país hospedeiro sobre os fluxos do país hospedeiro para o país de origem

(Continua)

\begin{tabular}{|c|c|c|c|c|c|c|c|c|c|c|c|c|}
\hline & \multicolumn{3}{|c|}{$\begin{array}{c}\text { V } \\
\text { Exportação }\end{array}$} & \multicolumn{3}{|c|}{$\begin{array}{c}\text { VI } \\
\text { Importação }\end{array}$} & \multicolumn{3}{|c|}{$\begin{array}{c}\text { VII } \\
\text { IDE saída }\end{array}$} & \multicolumn{3}{|c|}{$\begin{array}{c}\text { VIII } \\
\text { IDE entrada }\end{array}$} \\
\hline & Coe & & SD & Coe & & SD & Coef & & SD & Coef & & SD \\
\hline apex_ppp & & & & 0.657 & $*$ & 0.372 & & & & -0.063 & & 0.096 \\
\hline apei_br & 0.005 & & 0.065 & & & & 0.153 & $*$ & 0.086 & & & \\
\hline L.export & 0.854 & $* * *$ & 0.024 & & & & & & & & & \\
\hline L.import & & & & 0.208 & $*$ & 0.106 & & & & & & \\
\hline L.loginvestout & & & & & & & 0.337 & $* *$ & 0.154 & & & \\
\hline L.loginvestin & & & & & & & & & & 0.171 & $* * *$ & 0.056 \\
\hline wto_ptanumbers & 0.101 & $* * *$ & 0.027 & 0.816 & $* * *$ & 0.201 & -0.026 & $* *$ & 0.012 & -0.016 & & 0.017 \\
\hline wto_ftanumbers & 0.007 & & 0.075 & 1293 & & 0.871 & -0.022 & & 0.037 & 0.025 & & 0.050 \\
\hline hf_os & -0.003 & & 0.003 & -0.005 & & 0.026 & & & & & & \\
\hline db_tab_dtf & 0.005 & $* * *$ & 0.001 & 0.011 & & 0.013 & & & & & & \\
\hline db_sb_dtf & & & & & & & 0.000 & & 0.000 & 0.001 & & 0.000 \\
\hline hf_ffc & & & & & & & 0.003 & $* * *$ & 0.001 & 0.003 & $* * *$ & 0.001 \\
\hline hf_ff & & & & & & & -0.002 & $* *$ & 0.001 & -0.003 & $* *$ & 0.001 \\
\hline db_sb_timedays & & & & & & & 0.000 & & 0.000 & 0.000 & $* * *$ & 0.000 \\
\hline wef_gci_lsquality & & & & & & & 0.015 & & 0.016 & -0.001 & & 0.016 \\
\hline wef_gci_ebf & & & & & & & -0.010 & & 0.015 & -0.003 & & 0.014 \\
\hline gdpppp_o & 0.134 & $* *$ & 0.055 & 0.573 & $* * *$ & 0.306 & 0.203 & $* * *$ & 0.049 & 0.032 & $* * *$ & 0.010 \\
\hline gdpppp_d & 0.069 & $* *$ & 0.020 & -0.354 & & 0.140 & 0.019 & $*$ & 0.010 & 0.227 & $* * *$ & 0.031 \\
\hline gdppercapita_ppp & 0.101 & $* * *$ & 0.034 & 1.486 & $* * *$ & 0.336 & -0.009 & & 0.011 & 0.000 & & 0.000 \\
\hline bis_reer_brazil & -0.001 & & 0.002 & -0.006 & & 0.013 & -0.004 & $* * *$ & 0.001 & -0.009 & $* * *$ & 0.003 \\
\hline
\end{tabular}


Tabela 3 - Modelos de painéis dinâmicos para a presença da agência do país de origem no país hospedeiro sobre os fluxos do país hospedeiro para o país de origem

(Conclusão)

\begin{tabular}{lcccccccc}
\hline & \multicolumn{2}{c}{$\begin{array}{c}\text { V } \\
\text { Exportação }\end{array}$} & \multicolumn{2}{c}{$\begin{array}{c}\text { VI } \\
\text { Importação }\end{array}$} & \multicolumn{2}{c}{$\begin{array}{c}\text { VII } \\
\text { IDE saída }\end{array}$} & \multicolumn{2}{c}{ VIII } \\
& Coef. & SD & Coef. & SD & Coef. & SD & Coef. & SD \\
\hline Distance & -0.097 & 0.066 & -0.242 & 0.442 & -0.025 & 0.023 & -0.046 & 0.029 \\
gdp_var & & & & & -0.099 & 0.100 & -1 & 3531 \\
Inflation & & & & & 0.000 & 0.000 & -0.017 & 0.074 \\
_cons & 0.000 & 0.000 & 0.000 & 0.000 & 0.000 & 0.000 & 0.000 & 0.000 \\
AB test AR(1) & 0.041 & & 0.000 & & 0.028 & & 0.089 & \\
AB test AR(2) & 0.114 & & 0.169 & & 0.237 & & 0.633 & \\
R-square robust & 0.924 & & 0.712 & & 0.574 & & 0.313 & \\
Observações & 1.208 & & 1.288 & & 1.028 & & 1.063 & \\
\hline
\end{tabular}

$* \mathrm{p}<0.1 ; * * \mathrm{p}<0.05 ; * * * \mathrm{p}<0.01$

${ }^{1}$ Erro padrão robusto

Fonte: Elaborado pela autora

\subsection{Impacto da Aprendizagem da APEI sobre os fluxos do país de origem da agência para o país hospedeiro}

A Tabela 4 apresenta o resultado do modelo de painel dinâmico para a análise do impacto da aprendizagem da APEI sobre os fluxos do país de origem da agência para o país hospedeiro da mesma $(H 2 a)$. O esperado é que a aprendizagem da agência tenha um efeito positivo sobre os fluxos e que a aprendizagem seja maior no inicio das atividades. Com esse intuito, as variáveis de aprendizagem (apex_pppa e apei_br_a), têm métricas em logaritmos. Os modelos de IX a XII representam, na ordem, exportação, importação, saída de IDE e entrada de IDE. As variáveis apex_pppa e apei_br_a avaliam, respectivamente, a presença da APEX em países hospedeiros e a presença de agências de diferentes países no Brasil. A variável apex_pppa_log foi utilizada nos fluxos de saída do Brasil, ou seja, exportação (modelo IX) e saída de IDE (modelo XI), enquanto a variável apei_br_a_log aparece nos fluxos de importação (modelo X) e entrada de IDE (modelo XII).

As variáveis testadas foram as mesmas do que nos modelos de I a VIII, apenas com a variação da apex_ppp_a_log e apei_br_a_log.

As principais alterações nos coeficientes das variáveis em relação aos modelos anteriores ocorreram no coeficiente do câmbio no modelo XII (entrada de IDE), que passa a ser positivo, e no coeficiente da distância geográfica que passa a ser estatisticamente significante, no modelo XII. 
Conforme os resultados apresentados na tabela 4 , as variáveis de aprendizagem das agências aparecem como significativas nos fluxos comerciais (modelos IX e X), mas não significativas nos fluxos de investimentos (modelos XI e XII). Aqui, novamente, nos modelos de exportação (IX) e importação (X) o sinal do coeficiente foi como esperado, positivo, o que indica que o aprendizado das agências tem um impacto positivo sobre os fluxos comerciais. Contudo, no modelo de saída de IDE, o sinal do coeficiente foi negativo, enquanto no modelo de entrada de IDE, a variável foi omitida no modelo, por colinearidade com outras variáveis.

\section{Tabela 4 - Modelos de painéis dinâmicos para a aprendizagem da presença da agência do país de origem no país hospedeiro sobre os fluxos do país de origem para o país hospedeiro}

\begin{tabular}{|c|c|c|c|c|c|c|c|c|c|c|c|c|}
\hline \multirow[b]{3}{*}{ apex_pppa_log } & \multicolumn{3}{|c|}{$\begin{array}{c}\text { IX } \\
\text { Exportação }\end{array}$} & \multicolumn{3}{|c|}{$\begin{array}{c}\text { X } \\
\text { Importação }\end{array}$} & \multicolumn{3}{|c|}{$\begin{array}{c}\text { XI } \\
\text { IDE saída }\end{array}$} & \multicolumn{3}{|c|}{$\begin{array}{c}\text { XII } \\
\text { IDE entrada }\end{array}$} \\
\hline & \multicolumn{2}{|c|}{ Coef. } & \multirow{2}{*}{$\frac{\mathrm{SD}}{0.256}$} & \multicolumn{2}{|c|}{ Coef. } & \multirow{3}{*}{$\begin{array}{l}\text { SD } \\
0.665\end{array}$} & \multicolumn{2}{|c|}{ Coef. } & \multirow[t]{2}{*}{$\mathrm{SD}$} & \multicolumn{2}{|c|}{ Coef. } & \multirow[t]{2}{*}{$\mathrm{SD}$} \\
\hline & 0.660 & $* *$ & & & & & omitted & & & & & \\
\hline apei_br_a_log & & & & 1.236 & $*$ & & & & & -0.017 & & 0.017 \\
\hline L.export & 0.819 & $* * *$ & 0.055 & & & & & & & & & \\
\hline L.import & & & & 0.083 & & 0.111 & & & & & & \\
\hline L.loginvestout & & & & & & & 0.658 & $* * *$ & 0.062 & & & \\
\hline L.loginvestin & & & & & & & & & & 0.221 & $* *$ & 0.089 \\
\hline wto_ptanumbers & 0.121 & $* * *$ & 0.035 & 0.954 & $* * *$ & 0.221 & -0.010 & & 0.007 & -0.015 & & 0.018 \\
\hline wto_ftanumbers & -0.043 & & 0.062 & 0.000 & & 0.422 & -0.011 & & 0.017 & 0.038 & & 0.068 \\
\hline hf_os & -0.002 & & 0.003 & 0.027 & & 0.031 & & & & & & \\
\hline $\mathrm{db} \_t a b \_d t f$ & 0.004 & $* * *$ & 0.002 & 0.002 & & 0.015 & & & & & & \\
\hline $\mathrm{db} \_s b \_d t f$ & & & & & & & 0.000 & & 0.000 & 0.000 & & 0.000 \\
\hline hf_ffc & & & & & & & 0.002 & $* * *$ & 0.001 & 0.002 & $* * *$ & 0.001 \\
\hline hf_ff & & & & & & & -0.001 & $* *$ & 0.000 & -0.002 & $* *$ & 0.001 \\
\hline db_sb_timedays & & & & & & & 0.000 & & 0.000 & 0.000 & $* *$ & 0.000 \\
\hline wef_gci_lsquality & & & & & & & 0.023 & $* *$ & 0.011 & 0.004 & & 0.014 \\
\hline wef_gci_ebf & & & & & & & -0.019 & $*$ & 0.010 & -0.005 & & 0.013 \\
\hline gdpppp_o & 0.139 & & 0.085 & 0.618 & $* * *$ & 0.152 & 0.010 & & 0.006 & 0.026 & $* * *$ & 0.010 \\
\hline gdpppp_d & 0.075 & $* * *$ & 0.028 & -0.524 & & 0.360 & 0.109 & $* * *$ & 0.020 & -0.054 & $* *$ & 0.024 \\
\hline gdppercapita_ppp & 0.138 & $* * *$ & 0.042 & 1.691 & $* * *$ & 0.383 & -0.008 & & 0.007 & 0.000 & & 0.000 \\
\hline bis_reer_brazil & 0.000 & & 0.003 & 0.007 & & 0.013 & -0.002 & $* * *$ & 0.001 & 0.033 & $* * *$ & 0.006 \\
\hline Distance & -0.084 & & 0.081 & -0.293 & & 0.526 & -0.018 & & 0.015 & -0.051 & $*$ & 0.030 \\
\hline gdp_var & & & & & & & -0.044 & & 0.082 & -1.233 & & 3.595 \\
\hline Inflation & & & & & & & 0.000 & & 0.000 & 0.058 & & 0.064 \\
\hline _cons & 0.000 & & 0.000 & 0.000 & & 0.000 & 0.000 & & 0.000 & 0.000 & & 0.000 \\
\hline AB test AR(1) & 0.027 & & & 0.000 & & & 0.011 & & & 0.003 & & \\
\hline $\mathrm{AB}$ test $\mathrm{AR}(2)$ & 0.212 & & & 0.507 & & & 0.571 & & & 0.825 & & \\
\hline R-square robust & 0.931 & & & 0.661 & & & 0.736 & & & 0.365 & & \\
\hline Observações & 1.028 & & & 1.107 & & & 868 & & & 891 & & \\
\hline
\end{tabular}

${ }^{*} \mathrm{p}<0.1 ; * * \mathrm{p}<0.05 ; * * * \mathrm{p}<0.01$

${ }^{1}$ Erro padrão robusto

Fonte: Elaborado pela autora

A Figura 30 apresenta o resultado do teste da hipótese H2a para cada um dos modelos. 


\begin{tabular}{|l|l|l|}
\hline \multicolumn{1}{|c|}{ Fluxo } & \multicolumn{1}{c|}{ Hipóteses } & \multicolumn{1}{c|}{ Resultados } \\
\hline $\begin{array}{l}\text { Exportação } \\
\text { (H2aI) }\end{array}$ & $\begin{array}{l}\text { A aprendizagem da APEX no país hospedeiro aumenta o fluxo de } \\
\text { exportação do Brasil para o país hospedeiro. }\end{array}$ & Aceita. \\
\hline $\begin{array}{l}\text { Importação } \\
\text { (H2aII) }\end{array}$ & $\begin{array}{l}\text { A aprendizagem da APEI do país de origem no Brasil aumenta o fluxo } \\
\text { de importação do Brasil do país de origem. }\end{array}$ & Aceita. \\
\hline $\begin{array}{l}\text { IDE saída } \\
\text { (H2aIII) }\end{array}$ & $\begin{array}{l}\text { A aprendizagem da APEX no país hospedeiro aumenta o fluxo de IDE } \\
\text { brasileiro no país hospedeiro. }\end{array}$ & Rejeitada. \\
\hline $\begin{array}{l}\text { IDE entrada } \\
\text { (H2aIV) }\end{array}$ & $\begin{array}{l}\text { A aprendizagem da APEI do país de origem no Brasil aumenta o fluxo } \\
\text { de IDE do país de origem no Brasil. }\end{array}$ & Rejeitada. \\
\hline
\end{tabular}

Figura 30 - Resultado para a hipótese H2a

Fonte: Elaborado pela autora

\subsection{Impacto da aprendizagem da APEI sobre os fluxos do país hospedeiro para o país de origem da agência}

A Tabela 5 apresenta o resultado do modelo de painel dinâmico para a análise do impacto da aprendizagem da APEI sobre os fluxos do país hospedeiro para o país de origem da agência $(H 2 b)$. Ao contrario dos modelos de IX a XII, para o teste da hipótese H2b, a variável apex_pppa_log foi utilizada nos fluxos de entrada do Brasil, ou seja, importação (modelo XIV) e entrada de IDE (modelo XVI), enquanto a variável apei_br_a_log aparece nos fluxos de exportação (modelo XIII) e saída de IDE (modelo XV). A intenção desses modelos é verificar o impacto da aprendizagem das agências nos fluxos do país hospedeiro da agência para o país de destino.

Conforme os resultados apresentados na Tabela 5, as variáveis de aprendizagem das agências aparecem como não significativas em todos os fluxos. A Figura 31 apresenta o resultado do teste da hipótese $\mathrm{H} 2 \mathrm{~b}$ para cada um dos modelos.

\begin{tabular}{|l|l|l|}
\hline \multicolumn{1}{|c|}{ Fluxo } & \multicolumn{1}{c|}{ Hipóteses } & \multicolumn{1}{c|}{ Resultados } \\
\hline $\begin{array}{l}\text { Exportação } \\
\text { (H2bI) }\end{array}$ & $\begin{array}{l}\text { A aprendizagem da APEX no país hospedeiro aumenta o fluxo de } \\
\text { importação do Brasil com origem no país hospedeiro da agência. }\end{array}$ & Rejeitada. \\
\hline $\begin{array}{l}\text { Importação } \\
\text { (H2bII) }\end{array}$ & $\begin{array}{l}\text { A aprendizagem da APEI do país de origem no Brasil aumenta o fluxo de } \\
\text { exportação do Brasil para o país de origem da agência. }\end{array}$ & Rejeitada. \\
\hline $\begin{array}{l}\text { IDE saída } \\
\text { (H2bIII) }\end{array}$ & $\begin{array}{l}\text { A aprendizagem da APEX no país hospedeiro aumenta o fluxo de IDE do } \\
\text { país hospedeiro para o Brasil. }\end{array}$ & Rejeitada. \\
\hline $\begin{array}{l}\text { IDE entrada } \\
\text { (H2bIV) }\end{array}$ & $\begin{array}{l}\text { A aprendizagem da APEI do país de origem no Brasil aumenta o fluxo de } \\
\text { exportação do Brasil para o país de origem da agência. }\end{array}$ & Rejeitada. \\
\hline
\end{tabular}

\section{Figura 31 - Resultado para a hipótese 2B}

Fonte: Elaborado pela autora 
Tabela 5 - Modelos de painéis dinâmicos para a aprendizagem da presença da agência do país de origem no país hospedeiro sobre os fluxos do país hospedeiro para o país de origem

\begin{tabular}{|c|c|c|c|c|c|c|c|c|c|c|c|c|}
\hline & \multicolumn{3}{|c|}{$\begin{array}{c}\text { XIII } \\
\text { Exportação } \\
\end{array}$} & \multicolumn{3}{|c|}{$\begin{array}{c}\text { XIV } \\
\text { Importação }\end{array}$} & \multicolumn{3}{|c|}{$\begin{array}{c}\text { XV } \\
\text { IDE saída } \\
\end{array}$} & \multicolumn{3}{|c|}{$\begin{array}{c}\text { XVI } \\
\text { IDE entrada } \\
\end{array}$} \\
\hline & $\mathrm{Coe}$ & & SD & Coe & & SD & $\mathrm{Cos}$ & & SD & Coef & & SD \\
\hline apex_pppa_log & & & & 1.516 & & 1.039 & & & & omitted & & \\
\hline apei_br_a_log & 0.020 & & 0.073 & & & & -0.015 & & 0.011 & & & \\
\hline L.export & 0.820 & $* * *$ & 0.054 & & & & & & & & & \\
\hline L.import & & & & 0.092 & & 0.110 & & & & & & \\
\hline L.loginvestout & & & & & & & 0.657 & $* * *$ & 0.062 & & & \\
\hline L.loginvestin & & & & & & & & & & 0.221 & $* *$ & 0.089 \\
\hline wto_ptanumbers & 0.121 & $* * *$ & 0.034 & 0.930 & $* * *$ & 0.217 & -0.011 & & 0.007 & -0.015 & & 0.018 \\
\hline wto_ftanumbers & -0.041 & & 0.061 & 0.000 & & 0.426 & -0.011 & & 0.017 & 0.038 & & 0.068 \\
\hline hf_os & -0.002 & & 0.003 & 0.026 & & 0.030 & & & & & & \\
\hline db_tab_dtf & 0.004 & $* *$ & 0.002 & 0.003 & & 0.015 & & & & & & \\
\hline $\mathrm{db} \_s b \_d t f$ & & & & & & & 0.000 & & 0.000 & 0.000 & & 0.000 \\
\hline hf_ffc & & & & & & & 0.002 & $* * *$ & 0.001 & 0.002 & $* * *$ & 0.001 \\
\hline hf_ff & & & & & & & -0.001 & $* *$ & 0.000 & -0.002 & $* *$ & 0.001 \\
\hline db_sb_timedays & & & & & & & 0.000 & & 0.000 & 0.000 & $* *$ & 0.000 \\
\hline wef_gci_lsquality & & & & & & & 0.023 & $* *$ & 0.011 & 0.005 & & 0.014 \\
\hline wef_gci_ebf & & & & & & & -0.019 & $*$ & 0.010 & -0.005 & & 0.013 \\
\hline gdpppp_o & 0.137 & & 0.084 & 0.615 & $* * *$ & 0.150 & 0.110 & $* * *$ & 0.021 & 0.026 & $* * *$ & 0.010 \\
\hline gdpppp_d & 0.074 & $* * *$ & 0.028 & -0.477 & & 0.353 & 0.010 & & 0.007 & 0.198 & $* * *$ & 0.027 \\
\hline gdppercapita_ppp & 0.137 & $* * *$ & 0.041 & 1.658 & $* * *$ & 0.379 & -0.008 & & 0.007 & 0.000 & & 0.000 \\
\hline bis_reer_brazil & 0.000 & & 0.003 & 0.005 & & 0.013 & -0.002 & $* * *$ & 0.001 & -0.003 & & 0.005 \\
\hline Distance & -0.083 & & 0.081 & -0.319 & & 0.522 & -0.019 & & 0.015 & -0.050 & $*$ & 0.030 \\
\hline gdp_var & & & & & & & -0.044 & & 0.082 & -1.251 & & 3.592 \\
\hline Inflation & & & & & & & 0.000 & & 0.000 & 0.057 & & 0.064 \\
\hline _cons & 0.000 & & 0.000 & 0.000 & & 0.000 & 0.000 & & 0.000 & 0.000 & & 0.000 \\
\hline $\mathrm{AB}$ test $\mathrm{AR}(1)$ & 0.027 & & & 0.000 & & & 0.000 & & & 0.003 & & \\
\hline $\mathrm{AB}$ test $\mathrm{AR}(2)$ & 0.216 & & & 0.517 & & & 0.996 & & & 0.830 & & \\
\hline $\mathrm{R}$-square robust & 0.931 & & & 0.663 & & & 0.736 & & & 0.365 & & \\
\hline Observações & 1.028 & & & 1.107 & & & 868 & & & 891 & & \\
\hline
\end{tabular}

${ }^{*} \mathrm{p}<0.1 ; * * \mathrm{p}<0.05 ; * * * \mathrm{p}<0.01$

${ }^{1}$ Erro padrão robusto

Fonte: Elaborado pela autora

\subsection{Distância cultural}

A Tabela 6 apresenta os resultados do modelo de painel dinâmico para a análise do efeito da interação da agência com a distância cultural. O intuito deste modelo é verificar se a presença da APEI reduz o efeito negativo da distância cultural sobre o fluxo do país de origem para o país hospedeiro (H3).

O coeficiente da variável de interação mostra o quanto variou o coeficiente da distância cultural com a presença da agência. Logo, o coeficiente da interação indica um deslocamento da curva que mostra o efeito da distância cultural sobre o fluxo avaliado. Ao 
utilizar a distância cultural de Berry et. al., como pode ser observado nos modelos XVII, XVIII XIX e XX da Tabela 6, nota-se que os coeficientes da variável de distancia cultural, em todos os modelos, mostraram-se negativos, o que está de acordo com o esperado na teoria, que a distância cultural diminui os fluxos entre os países. Apesar disso, a variável só aparece como significativa na saída de IDE.

Já ao se analisar o coeficiente da variável de interação, o resultado que se observa é o quanto a presença da agência modificou o coeficiente da distância cultural na equação. Assim, nos modelos de exportação (XVII) e de importação (XVIII), nota-se que a agência teve um efeito positivo, reduzindo o impacto negativo da distância cultural sobre os fluxos comerciais. Esse efeito pode ser mais bem compreendido ao observarmos os gráficos com os deslocamentos das retas, conforme pode ser observado na Figura 33.

O que se observa em ambos os gráficos é que há um deslocamento para cima nas retas dos coeficientes da variável de distância cultural, quando a agência está presente. Isso indica que a presença da agência tende a reduzir efeitos negativos da distância cultural. O coeficiente da variável de interação, contudo, foi significativo no modelo de importação (XVIII). e no de saída de IDE (XIX) com coeficiente negativo.

Tabela 6 - Modelos de painéis dinâmicos para o efeito da interação da agência com a distância cultural medida de acordo com Berry, at.al. (2010)

(Continua)

\begin{tabular}{|c|c|c|c|c|c|c|c|c|c|c|c|c|}
\hline & \multicolumn{3}{|c|}{$\begin{array}{c}\text { XVII } \\
\text { Exportação }\end{array}$} & \multicolumn{3}{|c|}{$\begin{array}{c}\text { XVIII } \\
\text { Importação }\end{array}$} & \multicolumn{3}{|c|}{$\begin{array}{c}\text { XIX } \\
\text { IDE saída }\end{array}$} & \multicolumn{3}{|c|}{$\begin{array}{c}\text { XX } \\
\text { IDE entrada }\end{array}$} \\
\hline & Coet & & $\mathrm{SD}$ & Coe & & SD & Coet & & SD & Coef & & SD \\
\hline apex_ppp & 0.031 & & 0.120 & & & 0.362 & 0.349 & & & & & \\
\hline apei_br & & & & -0.180 & & & & & 0.261 & 0.201 & $*$ & 0.108 \\
\hline cdist_berry & -0.001 & & 0.001 & -0.004 & & 0.001 & -0.001 & $*$ & 0.005 & -0.001 & & 0.001 \\
\hline apex_ppp\#\#c.cdist_berry & 0.003 & & 0.010 & & & & -0.039 & $*$ & 0.014 & & & \\
\hline apei_br\#\#c.cdist_berry & & & & 0.024 & $*$ & 0.020 & & & & -0.009 & & 0.010 \\
\hline L.export & 0.585 & $* * *$ & 0.098 & & & & & & & & & \\
\hline L.L. export & 0.283 & $* *$ & 0.128 & & & & & & & & & \\
\hline L.import & & & & 0.204 & & & & & 0.131 & & & \\
\hline L.L.import & & & & 0.195 & $* *$ & & & & 0.093 & & & \\
\hline L.loginvestout & & & & & & 0.117 & 0.253 & $* *$ & & & & \\
\hline L.loginvestin & & & & & & & & & & 0.182 & $* * *$ & 0.054 \\
\hline wto_ptanumbers & 0.093 & $* *$ & 0.040 & 0.463 & $* * *$ & 0.022 & -0.061 & $* * *$ & 0.151 & -0.032 & & 0.024 \\
\hline wto_ftanumbers & 0.060 & & 0.058 & 0.387 & & 0.050 & -0.024 & & 0.359 & -0.005 & & 0.067 \\
\hline hf_os & -0.001 & & 0.004 & -0.021 & & & & & 0.028 & & & \\
\hline db_tab_dtf & 0.002 & & 0.003 & 0.000 & & & & & 0.017 & & & \\
\hline db_sb_dtf & & & & & & 0.001 & 0.003 & $*$ & & 0.001 & $* *$ & 0.001 \\
\hline hf_ffc & & & & & & 0.002 & 0.005 & $* * *$ & & 0.004 & $* *$ & 0.002 \\
\hline hf_ff & & & & & & 0.002 & -0.002 & & & -0.001 & & 0.002 \\
\hline db_sb_timedays & & & & & & 0.001 & 0.002 & $* *$ & & 0.003 & $*$ & 0.002 \\
\hline wef_gci_lsquality & & & & & & 0.022 & 0.024 & & & -0.006 & & 0.030 \\
\hline wef_gci_ebf & & & & & & 0.021 & -0.013 & & & 0.010 & & 0.028 \\
\hline
\end{tabular}


Tabela 6 - Modelos de painéis dinâmicos para o efeito da interação da agência com a distância cultural medida de acordo com Berry, et.al. (2010)

\begin{tabular}{|c|c|c|c|c|c|c|c|c|c|c|}
\hline \multirow[b]{3}{*}{ gdpppp_o } & \multicolumn{2}{|c|}{$\begin{array}{c}\text { XVII } \\
\text { Exportação }\end{array}$} & \multicolumn{2}{|c|}{$\begin{array}{c}\text { XVIII } \\
\text { Importação }\end{array}$} & \multicolumn{3}{|c|}{$\begin{array}{c}\text { XIX } \\
\text { IDE saída }\end{array}$} & \multicolumn{3}{|c|}{$\begin{array}{c}\text { XX } \\
\text { IDE entrada }\end{array}$} \\
\hline & Coef. & \multirow{2}{*}{$\frac{\mathrm{SD}}{0.070}$} & Coef. & \multirow{2}{*}{$\frac{\text { SD }}{0.053}$} & \multicolumn{2}{|c|}{ Coef. } & \multirow{2}{*}{$\frac{\mathrm{SD}}{0.187}$} & \multicolumn{2}{|c|}{ Coef. } & \multirow{2}{*}{$\frac{\mathrm{SD}}{0.022}$} \\
\hline & 0.031 & & $0.540 \quad * * *$ & & 0.227 & $* * *$ & & 0.049 & $* *$ & \\
\hline gdpppp_d & $0.096 * *$ & 0.042 & -0.162 & 0.019 & 0.070 & $* * *$ & 0.276 & 0.224 & $* * *$ & 0.033 \\
\hline gdppercapita_ppp & 0.086 & 0.054 & $1.284 * * *$ & 0.027 & -0.048 & $*$ & 0.383 & -0.045 & $*$ & 0.026 \\
\hline bis_reer_brazil & 0.002 & 0.003 & -0.011 & 0.002 & -0.005 & $* * *$ & 0.013 & -0.005 & $* * *$ & 0.002 \\
\hline Distance & 0.019 & 0.064 & -0.346 & 0.053 & -0.082 & & 0.330 & -0.043 & & 0.056 \\
\hline gdp_var & & & & 0.225 & -0.552 & $*$ & & -0.437 & $*$ & 0.255 \\
\hline Inflation & & & & 0.000 & 0.000 & & & 0.000 & & 0.000 \\
\hline cons & 0.000 & 0.000 & 0.000 & 0.000 & 0.000 & & 0.000 & 0.000 & & 0.000 \\
\hline $\mathrm{AB}$ test $\mathrm{AR}(1)$ & 0.000 & & 0.004 & & 0.030 & & & 0.082 & & \\
\hline $\mathrm{AB}$ test $\mathrm{AR}(2)$ & 0.158 & & 0.556 & & 0.169 & & & 0.645 & & \\
\hline R-square robust & 0.959 & & 0.820 & & 0.306 & & & 0.323 & & \\
\hline Observações & 660 & & 705 & & 586 & & & 586 & & \\
\hline
\end{tabular}

${ }^{*} \mathrm{p}<0.1 ; * * \mathrm{p}<0.05 ; * * * \mathrm{p}<0.01$

${ }^{1}$ Erro padrão robusto

Fonte: Elaborado pela autora

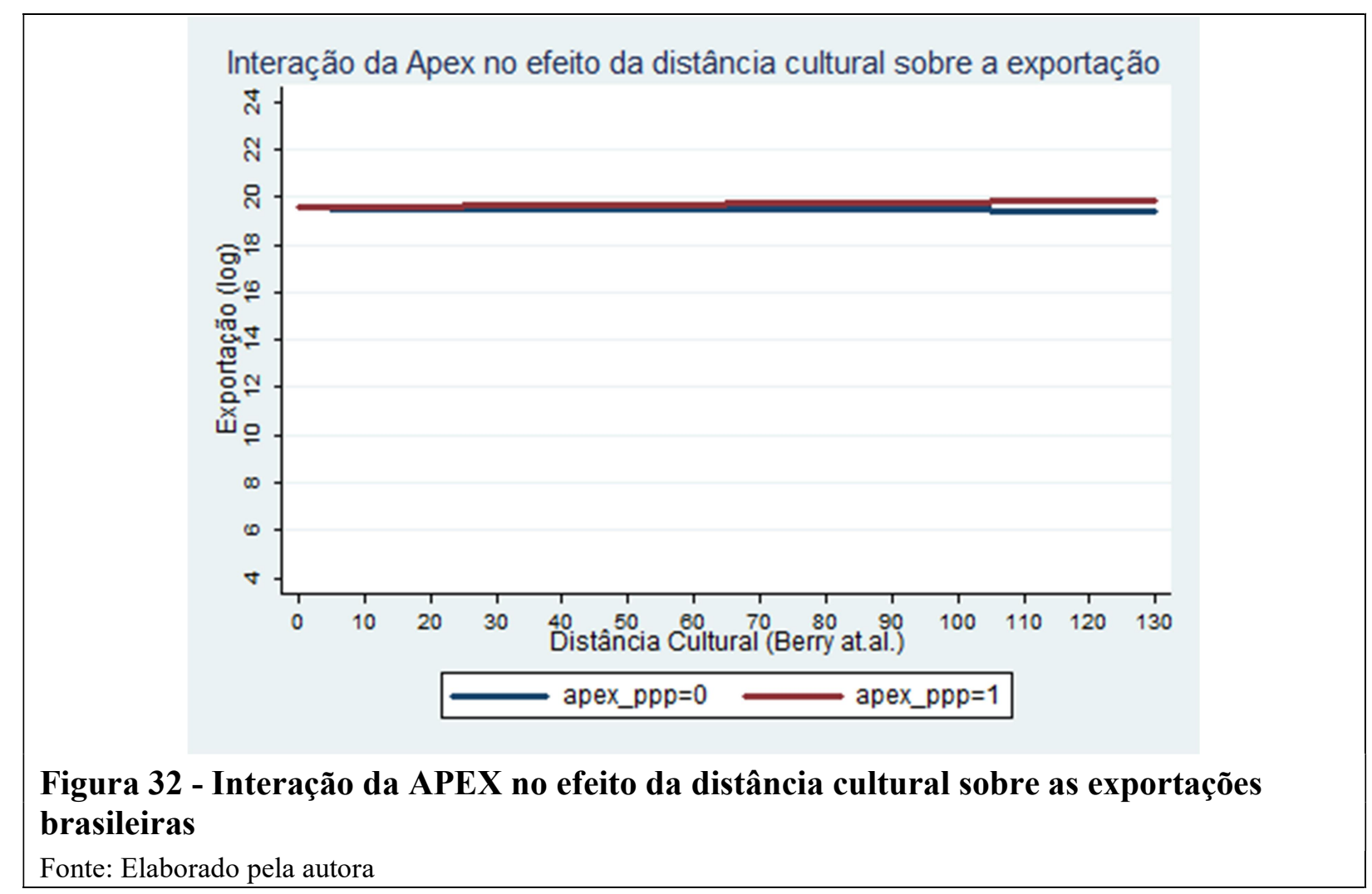

Conforme observado na Figura 32, a presença da agência reduz o efeito da distância cultural de forma praticamente imperceptível. 


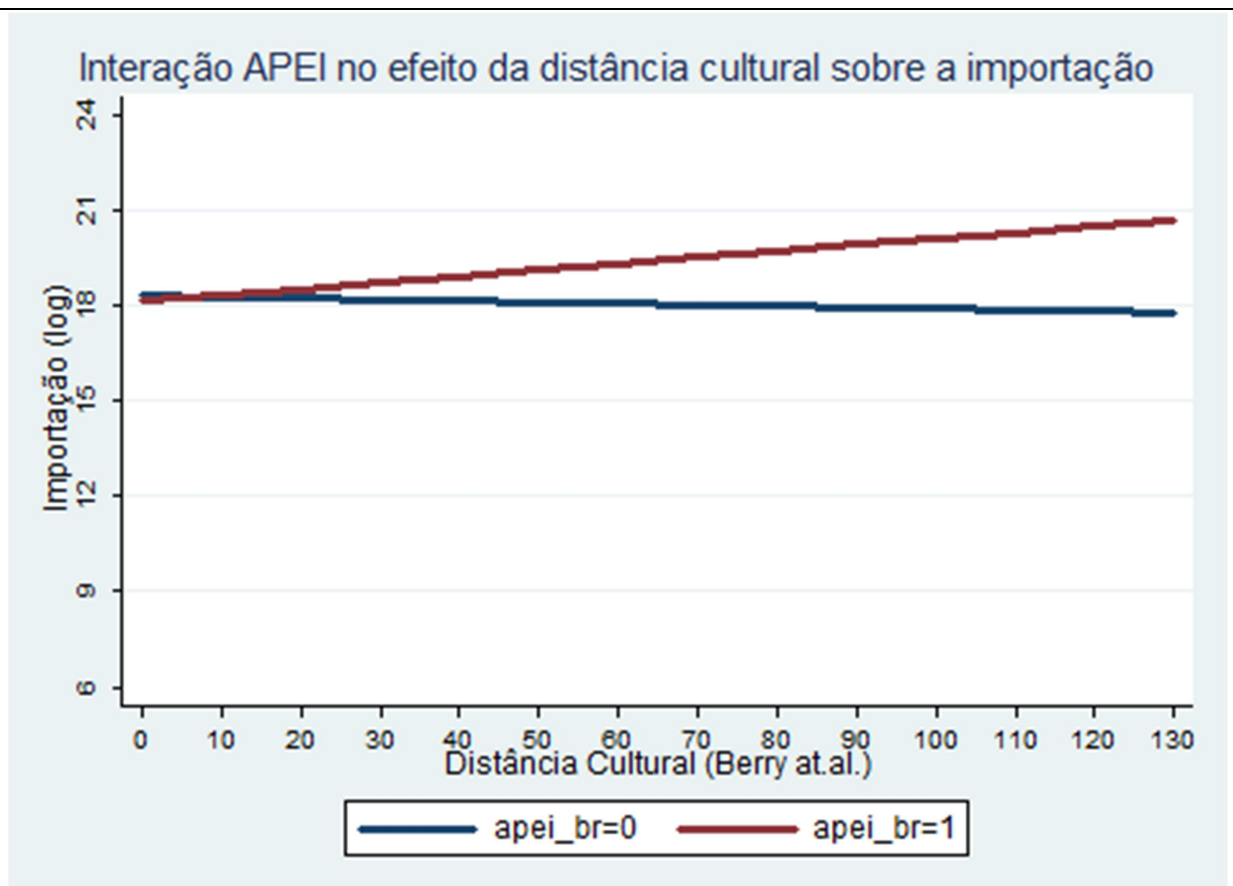

Figura 33 - Interação da APEI no efeito da distância cultural sobre as importações brasileiras

Fonte: Elaborado pela autora

Já, neste caso, nota-se um impacto maior da presença da APEI no deslocamento da curva.

Nos modelos de fluxos de investimentos, tanto no de saída (XIX), quanto no de entrada (XX) de IDE o coeficiente da interação mostra resultado inverso ao esperado, com sinal negativo, sendo que no modelo de saída de IDE a interação da APEX com a distância cultural foi significativa. Ou seja, isso indica que a agência teria um resultado ainda mais negativo sobre os fluxos de investimentos. As Figuras 34 e 35 deixam essa interpretação mais clara. Observa-se em ambos os gráficos que há um deslocamento para baixo dos coeficientes da variável de distância cultural, quando a agência está presente. 


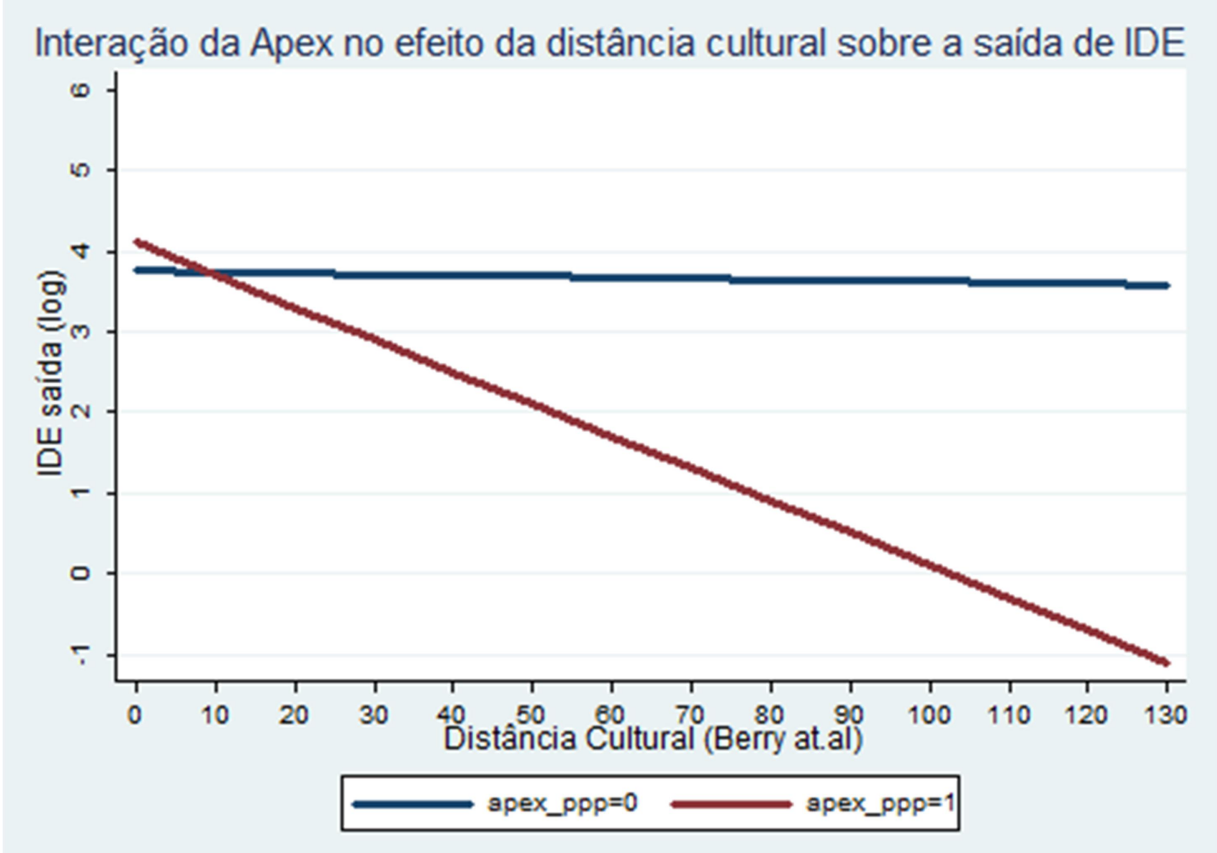

Figura 34 - Interação da APEX no efeito da distância cultural sobre a saída de IDE brasileiro

Fonte: Elaborado pela autora

A Figura 34 mostra que a APEX interage melhorando o de IDE brasileiro para países culturalmente mais próximos, contudo, reduz o fluxo para país culturalmente mais distante.

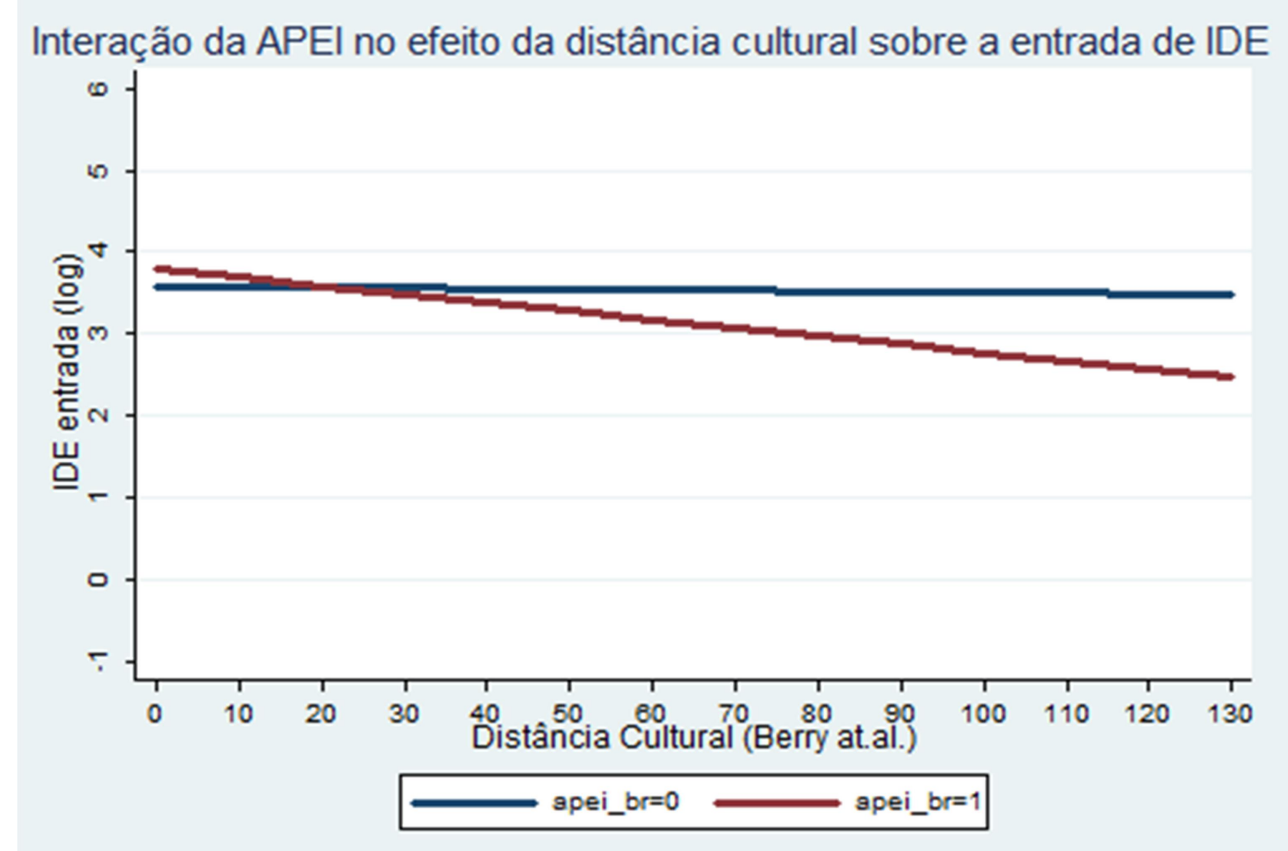

Figura 35 - Interação da APEI no efeito da distância cultural sobre a entrada de IDE do Brasil

Fonte: Elaborado pela autora 
Assim como no caso da presença da APEX na análise do efeito da distância cultural sobre o fluxo de IDE brasileiro no exterior, APEIs no Brasil têm efeito semelhante sobre os fluxos de entrada de IDE no Brasil. No caso de países culturalmente mais próximos, a presença da agência tornará o fluxo maior, enquanto no caso de países culturalmente mais distantes, o fluxo tende a ser reduzido.

A Figura 36 apresenta os resultados do teste da hipótese H3 para cada um dos modelos analisados com a distância cultural segundo a métrica de Berry et.al..

\begin{tabular}{|l|l|l|}
\hline \multicolumn{1}{|c|}{ Fluxo } & \multicolumn{1}{c|}{ Hipóteses } & \multicolumn{1}{c|}{ Resultados } \\
\hline $\begin{array}{l}\text { Exportação } \\
\text { (H3a) }\end{array}$ & $\begin{array}{l}\text { A APEX reduz o efeito negativo da distância cultural sobre o fluxo de } \\
\text { exportação do Brasil para o país hospedeiro da agência. }\end{array}$ & Rejeitada. \\
\hline $\begin{array}{l}\text { Importação } \\
(\mathrm{H} 3 \mathrm{~b})\end{array}$ & $\begin{array}{l}\text { A APEI reduz o efeito negativo da distância cultural sobre o fluxo de } \\
\text { importação do Brasil em relação ao país de origem da agência. }\end{array}$ & Aceita. \\
\hline $\begin{array}{l}\text { IDE saída } \\
(\mathrm{H} 3 \mathrm{c})\end{array}$ & $\begin{array}{l}\text { A APEX reduz o efeito negativo da distância cultural sobre o fluxo de } \\
\text { saída de IDE do Brasil para o país hospedeiro da agência. }\end{array}$ & Rejeitada. \\
\hline $\begin{array}{l}\text { IDE entrada } \\
(\mathrm{H} 3 \mathrm{~d})\end{array}$ & $\begin{array}{l}\text { A APEI reduz o efeito negativo da distância cultural sobre o fluxo de } \\
\text { entrada de IDE no Brasil em relação ao país de origem da agência. }\end{array}$ & Rejeitada. \\
\hline
\end{tabular}

Figura 36 - Resultado para a hipótese H3 com a distância cultural de Berry at.al.

Fonte: Elaborado pela autora

\subsection{Distância geográfica}

A Tabela 7 apresenta o resultado do modelo de painel dinâmico para a análise do efeito da interação da agência com a distância geográfica. As variáveis de interação são apex_ppp\#\#c.distance e apei_br\#\#c.distance. O intuito deste modelo é verificar se a presença da APEI reduz o efeito negativo da distância geográfica sobre o fluxo do país de origem para o país hospedeiro (H4).

Como pode ser observada na Tabela 7 , a variável distância apresenta coeficiente negativo nos modelos de exportação (XXV), importação (XXVI), saída de IDE (XXVII) e entrada de IDE (XXVIII). Este resultado está de acordo com o esperado na teoria, que a distância geográfica diminui os fluxos entre os países.

Já ao se analisar o coeficiente da variável de interação, o resultado que se observa é o quanto a presença da agência modificou o coeficiente da distância geográfica na equação. Assim, nos modelos de exportação, importação e saída de IDE, nota-se que a agência teve um efeito positivo, reduzindo o impacto negativo da distância geográfica sobre os fluxos 
estudados. Esse efeito pode ser mais bem compreendido ao observarmos os gráficos com os deslocamentos das retas, conforme pode ser observado nas Figuras 37, 38 e 39. 
Tabela 7 - Modelos de painéis dinâmicos para o efeito da interação da agência com a distância geográfica (logarítmica) entre os países parceiros

\begin{tabular}{|c|c|c|c|c|c|c|c|c|c|c|c|c|}
\hline & \multicolumn{3}{|c|}{$\begin{array}{c}\text { XXV } \\
\text { Exportação }\end{array}$} & \multicolumn{3}{|c|}{$\begin{array}{c}\text { XXVI } \\
\text { Importação }\end{array}$} & \multicolumn{3}{|c|}{$\begin{array}{c}\text { XXVII } \\
\text { IDE saídas }\end{array}$} & \multicolumn{3}{|c|}{$\begin{array}{c}\text { XXVIII } \\
\text { IDE entrada }\end{array}$} \\
\hline & \multicolumn{2}{|c|}{ Coef. } & $\mathrm{SD}$ & \multicolumn{2}{|c|}{ Coef. } & $\mathrm{SD}$ & \multicolumn{2}{|c|}{ Coef. } & $\mathrm{SD}$ & \multicolumn{2}{|c|}{ Coef. } & $\mathrm{SD}$ \\
\hline apex_ppp & -1.482 & & 1.068 & & & 2.325 & -2.009 & & & & & \\
\hline apei_br & & & & -8.963 & $*$ & & & & 4.675 & 1.011 & & 0.727 \\
\hline Distance & -0.091 & & 0.067 & -0.335 & & 0.028 & -0.034 & & 0.453 & -0.021 & & 0.027 \\
\hline apex_ppp\#\#c.distance & 0.179 & & 0.119 & & & & 0.211 & & 0.519 & & & \\
\hline apei_br\#\#c.distance & & & & 1.044 & $* *$ & 0.257 & & & & -0.099 & & 0.085 \\
\hline L.export & 0.855 & $* * *$ & 0.024 & & & & & & & & & \\
\hline L.import & & & & 0.209 & $* *$ & & & & 0.106 & & & \\
\hline L.loginvestout & & & & & & 0.137 & 0.265 & $*$ & & & & \\
\hline L.loginvestin & & & & & & & & & & 0.197 & $* * *$ & 0.064 \\
\hline wto_ptanumbers & 0.107 & $* * *$ & 0.028 & 0.792 & $* * *$ & 0.012 & -0.026 & $* *$ & 0.196 & -0.017 & & 0.015 \\
\hline wto_ftanumbers & 0.011 & & 0.075 & 1506 & $*$ & 0.029 & -0.014 & & 0.872 & -0.002 & & 0.041 \\
\hline hf_os & -0.003 & & 0.003 & -0.008 & & & & & 0.026 & & & \\
\hline $\mathrm{db} \_$tab_dtf & 0.005 & $* * *$ & 0.001 & 0.01 & & & & & 0.013 & & & \\
\hline $\mathrm{db} \_s b \_d t f$ & & & & & & 0.001 & 0.000 & & & 0.001 & & 0.001 \\
\hline hf_ffc & & & & & & 0.001 & 0.004 & $* * *$ & & 0.003 & $* * *$ & 0.001 \\
\hline hf_ff & & & & & & 0.001 & -0.003 & $* * *$ & & -0.002 & $*$ & 0.001 \\
\hline db_sb_timedays & & & & & & 0.000 & 0.000 & $*$ & & 0.000 & & 0.000 \\
\hline wef_gci_lsquality & & & & & & 0.018 & 0.037 & $* *$ & & 0.011 & & 0.020 \\
\hline wef_gci_ebf & & & & & & 0.017 & -0.033 & $* *$ & & -0.008 & & 0.018 \\
\hline gdpppp_o & 0.132 & $* *$ & 0.054 & 0.567 & $* * *$ & 0.045 & 0.226 & $* * *$ & 0.140 & 0.019 & & 0.013 \\
\hline gdpppp_d & 0.066 & $* * *$ & 0.020 & -0.285 & & 0.013 & 0.027 & $* *$ & 0.310 & 0.227 & $* * *$ & 0.021 \\
\hline gdppercapita_ppp & 0.097 & $* * *$ & 0.033 & 1501 & $* * *$ & 0.013 & -0.010 & & 0.337 & -0.012 & & 0.014 \\
\hline bis_reer_brazil & -0.001 & & 0.002 & -0.006 & & 0.001 & -0.004 & $* * *$ & 0.013 & -0.004 & $* * *$ & 0.001 \\
\hline gdp_var & & & & & & 0.118 & -0.150 & & & -0.182 & & 0.131 \\
\hline Inflation & & & & & & 0.000 & 0.000 & & & 0.000 & & 0.000 \\
\hline _cons & 0.000 & & 0.000 & 0.000 & & 0.000 & 0.000 & & 0.000 & 0.000 & & 0.000 \\
\hline AB test AR(1) & 0.041 & & & 0.000 & & & 0.038 & & & 0.076 & & \\
\hline $\mathrm{AB}$ test $\mathrm{AR}(2)$ & 0.114 & & & 0.169 & & & 0.187 & & & 0.707 & & \\
\hline $\mathrm{R}$-square robust & 0.924 & & & 0.713 & & & 0.544 & & & 0.323 & & \\
\hline Observações & 1.208 & & & 1.288 & & & 1.028 & & & 1.028 & & \\
\hline
\end{tabular}

$* \mathrm{p}<0.1 ; * * \mathrm{p}<0.05 ; * * * \mathrm{p}<0.01$

${ }^{1}$ Erro padrão robusto

Fonte: Elaborado pela autora 
As Figuras 37, 38, 39 e 40 permitem uma melhor visualização do efeito da interação nos modelos apresentados.
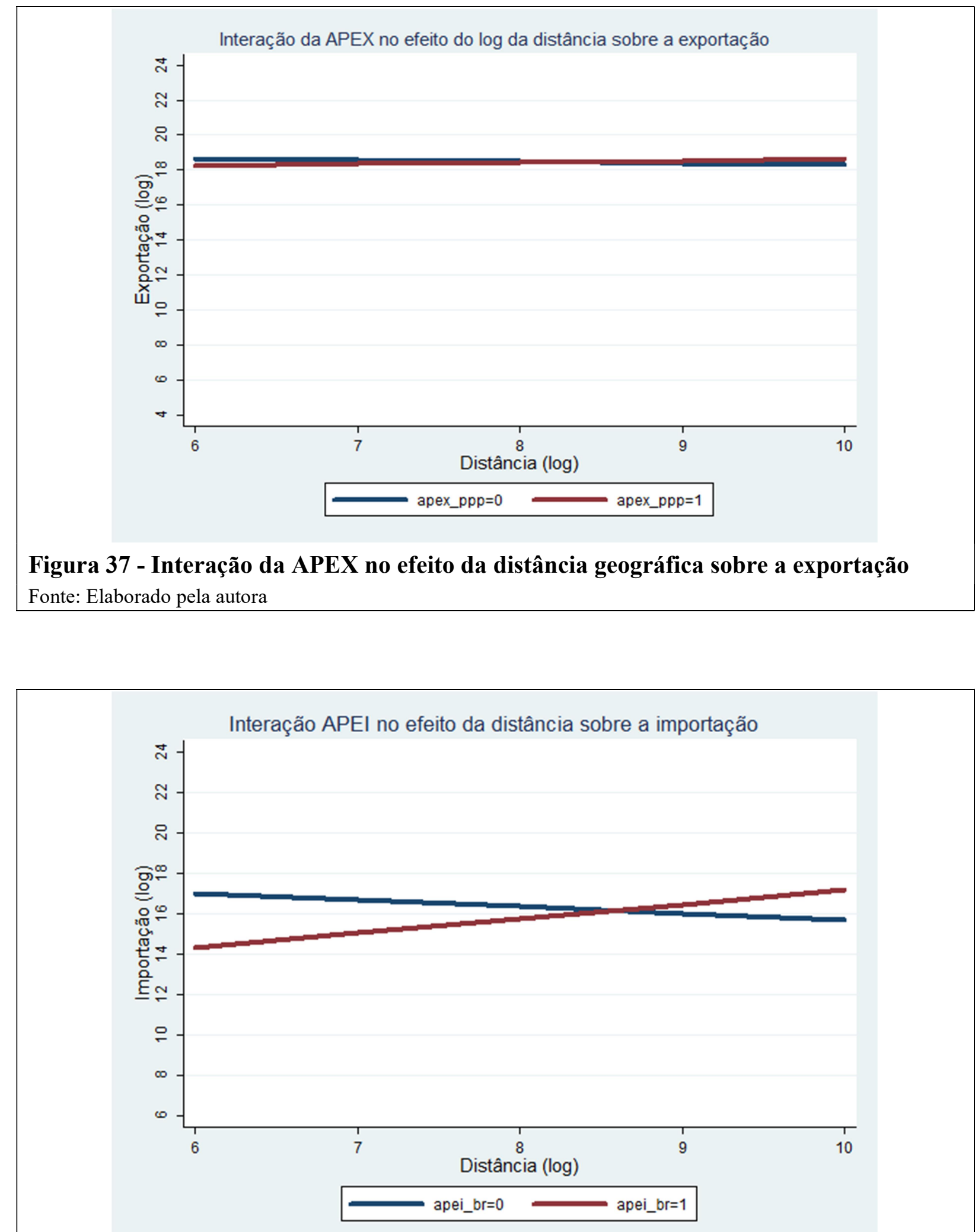

Figura 38 - Interação da APEI no efeito da distância geográfica sobre a importação Fonte: Elaborado pela autora 


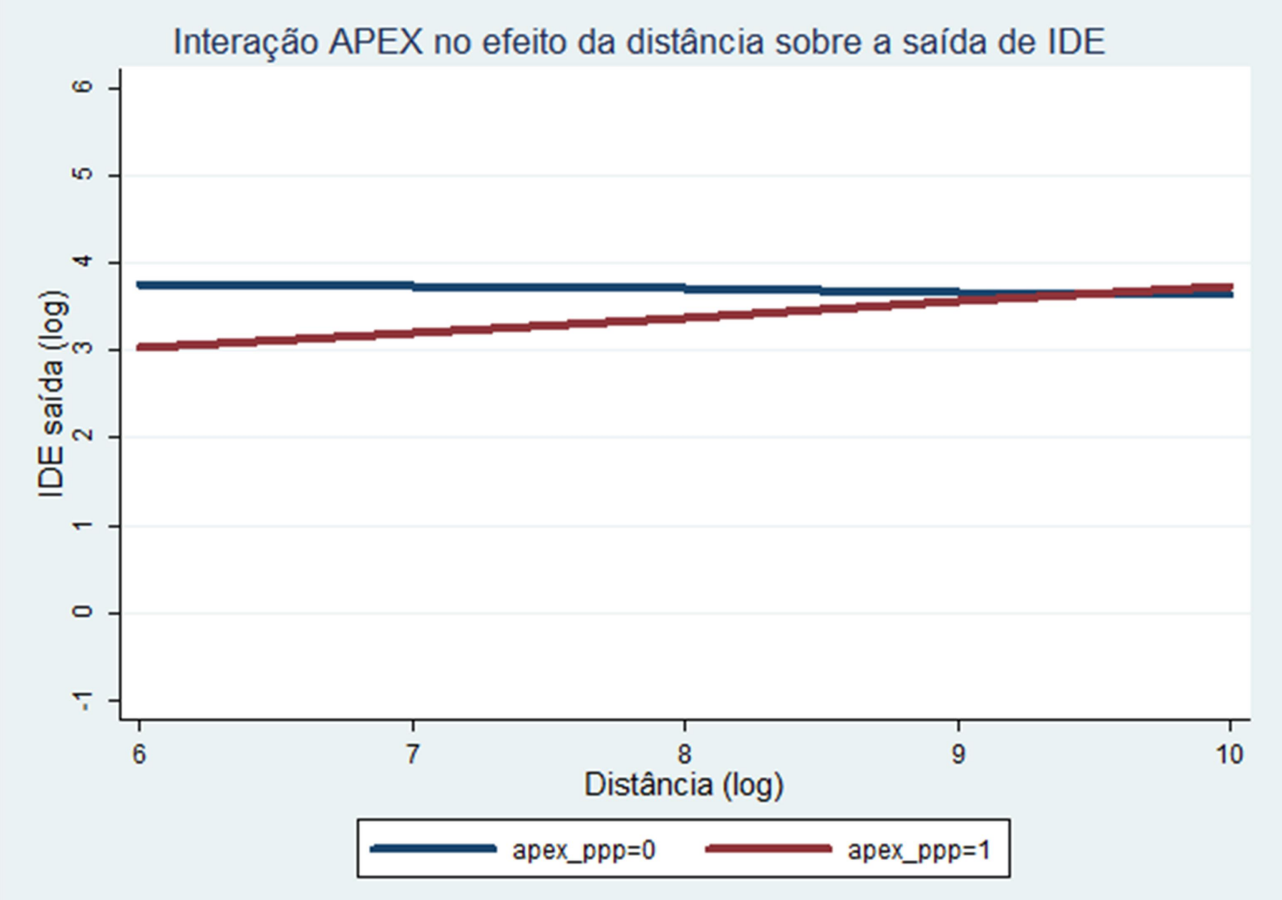

Figura 39 - Interação da APEX no efeito da distância geográfica sobre a saída de IDE

Fonte: Elaborado pela autora

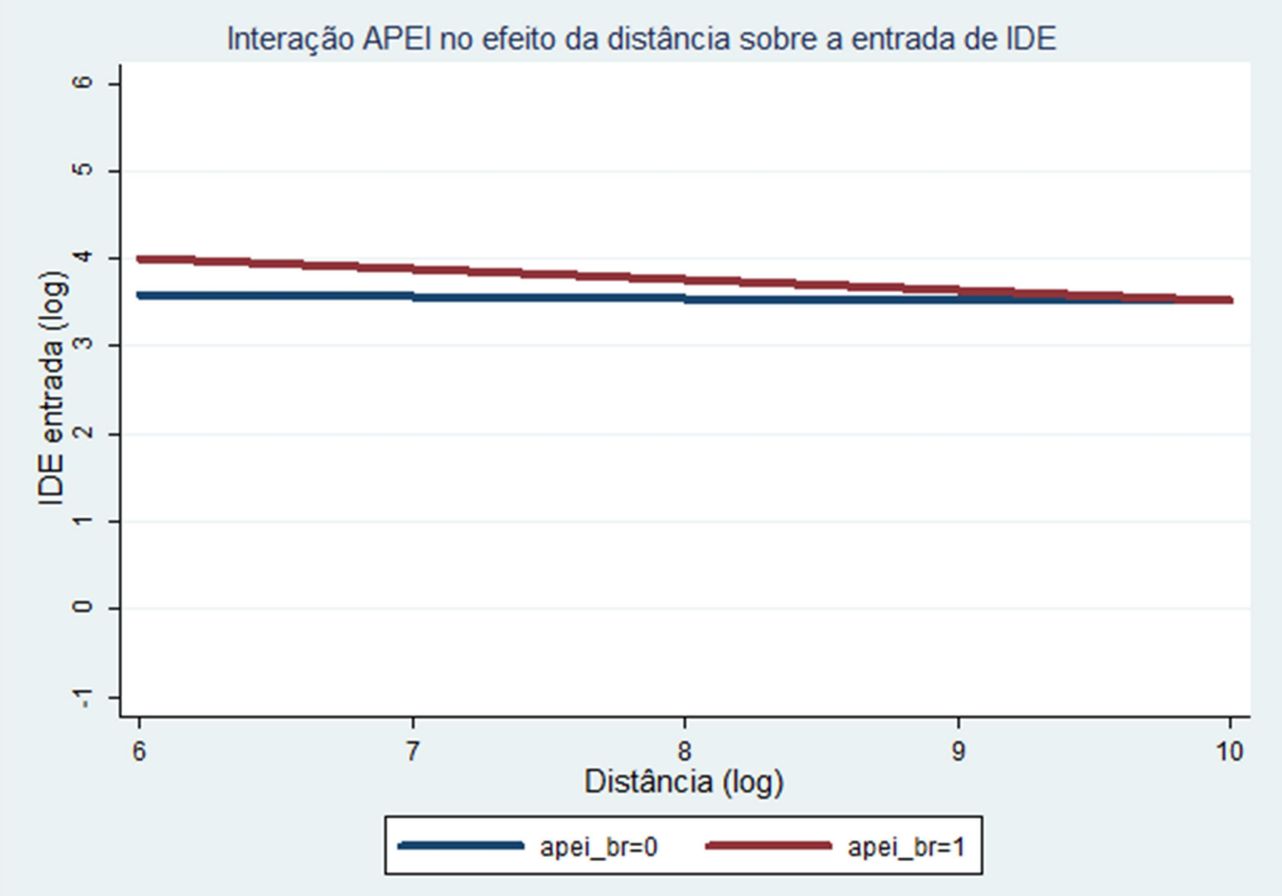

Figura 40 - Interação da APEI no efeito da distância geográfica sobre a entrada de IDE

Fonte: Elaborado pela autora 
A Figura 41 apresenta o resultado do teste da hipótese H4 para cada um dos modelos analisados com a interação da agência e da distância geográfica.

\begin{tabular}{|l|l|l|}
\hline \multicolumn{1}{|c|}{ Fluxo } & \multicolumn{1}{c|}{ Hipóteses } & \multicolumn{1}{c|}{ Resultados } \\
\hline $\begin{array}{l}\text { Exportação } \\
\text { (H4a) }\end{array}$ & $\begin{array}{l}\text { A APEX reduz o efeito negativo da distância geográfica sobre o fluxo de } \\
\text { exportação do Brasil para o país hospedeiro da agência. }\end{array}$ & Rejeitada. \\
\hline $\begin{array}{l}\text { Importação } \\
\text { (H4b) }\end{array}$ & $\begin{array}{l}\text { A APEI reduz o efeito negativo da distância geográfica sobre o fluxo de } \\
\text { importação do Brasil em relação ao país de origem da agência. }\end{array}$ & Aceita. \\
\hline $\begin{array}{l}\text { IDE saída } \\
\text { (H4c) }\end{array}$ & $\begin{array}{l}\text { A APEX reduz o efeito negativo da distância geográfica sobre o fluxo de } \\
\text { saída de IDE do Brasil para o país hospedeiro da agência. }\end{array}$ & Rejeitada. \\
\hline $\begin{array}{l}\text { IDE entrada } \\
\text { (H4d) }\end{array}$ & $\begin{array}{l}\text { A APEI reduz o efeito negativo da distância geográfica sobre o fluxo de } \\
\text { entrada de IDE no Brasil em relação ao país de origem da agência. }\end{array}$ & Rejeitada. \\
\hline
\end{tabular}

\section{Figura 41 - Resultado para a hipótese H4}

Fonte: Elaborado pela autora

\subsection{Controle societário e autonomia organizacional}

Para os testes de avaliação do efeito do controle societário e da autonomia organizacional foi selecionada a variável apei_br, com o intuito de que se obtivesse um maior número de observações, uma vez que apex_ppp só mostra os dados para a agência brasileira, o que impediria a análise comparativa entre as agências. Além disso, foram selecionados para o teste da hipótese apenas os fluxos nos quais essa variável mostrou-se estatisticamente significante. Logo, partindo-se dos modelos testados na hipótese H1a e H1b, os modelos selecionados foram o de importação e o de saída de IDE. 
A Figura 42 apresenta o resultado das características organizacionais das agências analisadas.

\begin{tabular}{|c|c|c|c|c|c|}
\hline País & APEI & $\begin{array}{c}\text { Ano } \\
\text { entrada } \\
\text { Brasil }\end{array}$ & $\begin{array}{c}\text { Controle } \\
\text { societário } \\
\text { público (1), } \\
\text { privado (2) ou } \\
\text { parceria } \\
\text { público- } \\
\text { privada(3). }\end{array}$ & $\begin{array}{c}\text { Subordinação } \\
\text { presidência } \\
\text { (1), ministério } \\
\text { (2). }\end{array}$ & $\begin{array}{c}\text { Autonomia } \\
\text { organizacional } \\
\text { escritório no } \\
\text { consulado (1), } \\
\text { escritório } \\
\text { proprio2. }\end{array}$ \\
\hline Austrália & Austrade & 1993 & 1 & 2 & 1 \\
\hline Chile & Prochile & 1978 & 1 & 2 & 2 \\
\hline Colômbia & Procolombia & 2012 & 1 & 2 & 2 \\
\hline $\begin{array}{l}\text { República } \\
\text { Tcheca }\end{array}$ & Czech Trade & 2006 & 1 & 2 & 2 \\
\hline Equador & Proecuador & 2009 & 1 & 1 & 1 \\
\hline Espanha & ICEX & 1996 & 3 & 2 & 2 \\
\hline França & $\begin{array}{c}\text { UBIFRANCE - Business } \\
\text { France }\end{array}$ & 2015 & 3 & 2 & 2 \\
\hline Alemanha & BTAI - GTAI & 1997 & 1 & 2 & 1 \\
\hline Irlanda & IDA Ireland & 2009 & 1 & 2 & 2 \\
\hline Israel & Invest in Israel & 2005 & 1 & 2 & 1 \\
\hline Itália & $\begin{array}{c}\text { Italian Trade Promotion } \\
\text { Agency }\end{array}$ & 1964 & 1 & 2 & 1 \\
\hline Japão & Jetro & 1972 & 1 & 2 & 2 \\
\hline $\begin{array}{l}\text { Coréia do } \\
\text { Sul }\end{array}$ & Kotra & 1960 & 3 & 2 & 2 \\
\hline México & Promexico & 2008 & 1 & 2 & 2 \\
\hline Holanda & NFIA Brazil & 2012 & 1 & 1 & 1 \\
\hline $\begin{array}{c}\text { Nova } \\
\text { Zelândia }\end{array}$ & $\begin{array}{c}\text { New Zealend Trade and } \\
\text { Investment }\end{array}$ & 1999 & 1 & 2 & 1 \\
\hline Portugal & AICEP Portugal Global & 2007 & 1 & 2 & 1 \\
\hline Suíça & Switzerland Global Enterprise & 2013 & 3 & 2 & 1 \\
\hline Reino Unido & Uktrade & 2003 & 1 & 2 & 2 \\
\hline
\end{tabular}

\section{Figura 42 - Características organizacionais das agências analisadas}

Fonte: Elaborado pela autora

A Tabela 8 apresenta o resultado do modelo de painel dinâmico para a análise da diferença de resultado ocasionado pelos diferentes controles societários das agências, que 
podem ser público ou parceria público-privada, uma vez que nossa amostra não continha nenhuma agência de capital privado.

Tabela 8 - Modelos de painéis dinâmicos para o impacto do controle societário no efeito das agências sobre os fluxos

\begin{tabular}{|c|c|c|c|c|c|c|}
\hline \multirow[b]{3}{*}{ L.import } & \multicolumn{3}{|c|}{$\begin{array}{c}\text { XXIX } \\
\text { Importação }\end{array}$} & \multicolumn{3}{|c|}{$\begin{array}{c}\text { XXX } \\
\text { IDE saída }\end{array}$} \\
\hline & \multicolumn{2}{|c|}{ Coef. } & \multirow{2}{*}{$\begin{array}{l}\text { SD } \\
0.106\end{array}$} & \multicolumn{2}{|c|}{ Coef. } & \multirow[t]{2}{*}{ SD } \\
\hline & 0.208 & $*$ & & & & \\
\hline \multicolumn{7}{|l|}{ L.loginvestin } \\
\hline L.loginvestout & & & & 0.232 & * & 0.139 \\
\hline APEI parceria público privada em relação a pública & 0.560 & & 0.444 & 0.153 & & 0.149 \\
\hline Não ter APEI em relação a APEI pública & -0.417 & & 0.333 & -0.170 & * & 0.097 \\
\hline wto_ptanumbers & 0.774 & $* * *$ & 0.196 & -0.032 & $* * *$ & 0.012 \\
\hline wto_ftanumbers & 1.252 & & 0.886 & -0.023 & & 0.038 \\
\hline hf_os & -0.008 & & 0.026 & & & \\
\hline db_tab_dtf & 0.010 & & 0.013 & & & \\
\hline db_sb_dtf & & & & 0.000 & & 0.000 \\
\hline hf_ffc & & & & 0.002 & $* * *$ & 0.001 \\
\hline hf_ff & & & & -0.003 & $* * *$ & 0.001 \\
\hline db_sb_timedays & & & & 0.000 & $*$ & 0.000 \\
\hline wef_gci_lsquality & & & & 0.001 & & 0.017 \\
\hline wef_gci_ebf & & & & 0.002 & & 0.016 \\
\hline gdpppp_o & 0.573 & $* * *$ & 0.141 & -0.044 & $* * *$ & 0.038 \\
\hline gdpppp_d & -0.286 & & 0.304 & 0.025 & $* * *$ & 0.010 \\
\hline gdppercapita_ppp & 1.498 & $* * *$ & 0.337 & 0.000 & & 0.000 \\
\hline bis_reer_brazil & -0.007 & & 0.013 & 0.029 & $* * *$ & 0.003 \\
\hline Distance & -0.287 & & 0.444 & -0.039 & & 0.026 \\
\hline gdp_var & & & & -1.437 & & 1.149 \\
\hline Inflation & & & & 0.128 & $* *$ & 0.055 \\
\hline _cons & 0.000 & & 0.000 & 0.000 & & 0.000 \\
\hline $\mathrm{AB}$ test $\mathrm{AR}(1)$ & 0.000 & & & 0.042 & & \\
\hline $\mathrm{AB}$ test $\mathrm{AR}(2)$ & 0.169 & & & 0.189 & & \\
\hline R-square robust & 0.712 & & & 0.561 & & \\
\hline Observações & 1.288 & & & 1.067 & & \\
\hline
\end{tabular}

${ }^{*} \mathrm{p}<0.1 ; * * \mathrm{p}<0.05 ; * * * \mathrm{p}<0.01$

${ }^{1}$ Erro padrão robusto

Fonte: Elaborado pela autora

No resultado da Tabela 8 pode-se observar que o modelo separa a variável APEI em duas formas. Na primeira ele compara o coeficiente da APEI com capital público-privado em relação a APEIs de capital público. Aqui os coeficientes apresentados tanto no modelo de importação, quanto no de saída de IDE, apesar de não significativos, são positivos, o que indica que as agências de capital público-privado são mais eficientes do que aquelas de capital público. Na segunda ele compara o resultado de não ter APEI em relação à APEI de capital público. Aqui os coeficientes de ambos os modelos foram negativos, o que indica que a 
presença da APEI é mais eficiente do que não ter a APEI. Contudo, neste caso a variável também não se mostrou significativa.

A Figura 43 apresenta o resultado do teste da hipótese H5a para cada um dos modelos analisados.

\begin{tabular}{|l|l|l|}
\hline \multicolumn{1}{|c|}{ Fluxo } & \multicolumn{1}{c|}{ Hipóteses } & \multicolumn{1}{c|}{ Resultados } \\
\hline $\begin{array}{l}\text { Importação } \\
\text { (H5aI) }\end{array}$ & $\begin{array}{l}\text { O impacto de APEIs de capital público-privado no fluxo de importação } \\
\text { brasileiro do país de origem da APEI é maior do que o impacto das } \\
\text { APEIs de capital público. }\end{array}$ & Rejeitada. \\
\hline $\begin{array}{l}\text { IDE saída } \\
\text { (H5aII) }\end{array}$ & $\begin{array}{l}\text { O impacto de APEIs com capital público-privado no fluxo de saída de } \\
\text { IDE do Brasil para o país de origem da APEI é maior do que o de APEI } \\
\text { de capital público. }\end{array}$ & Rejeitada. \\
\hline
\end{tabular}

Figura 42 - Resultado para a hipótese H5a

Fonte: Elaborado pela autora

A hipótese H5b tem a intenção de verificar o impacto da autonomia sobre o resultado das APEIs. Para isso, estabeleceu-se como critério de avaliação da autonomia se as agências no país hospedeiro estão em escritórios próprios ou em consulados. A Tabela 9 apresenta o resultado do modelo de painel dinâmico para a análise da diferença de resultado ocasionado pelas diversas estruturas organizacionais das agências, no que se refere ao tipo de estrutura do escritório no país hospedeiro, que pode ser escritório próprio ou escritório no consulado do país. 
Tabela 9 - Modelos de painéis dinâmicos para o efeito das diferentes autonomias nos fluxos entre os países

\begin{tabular}{|c|c|c|c|c|c|c|}
\hline & \multicolumn{3}{|c|}{$\begin{array}{c}\text { XXXI } \\
\text { Importação }\end{array}$} & \multicolumn{3}{|c|}{$\begin{array}{l}\text { XXXII } \\
\text { IDE saída }\end{array}$} \\
\hline & Coef & & SD & & oef. & SD \\
\hline L.import & 0.208 & $*$ & 0.106 & & & \\
\hline L.loginvestout & & & & 0.230 & & 0.137 \\
\hline $\begin{array}{l}\text { APEI com escritório próprio em relação à } \\
\text { APEI com escritório no consulado }\end{array}$ & -0.167 & & 0.473 & 0.127 & & 0.161 \\
\hline $\begin{array}{l}\text { Não ter APEI em relação a } \\
\text { APEI com escritório no consulado }\end{array}$ & -0.609 & & 0.406 & -0.113 & & 0.138 \\
\hline wto_ptanumbers & 0.784 & $* * *$ & 0.198 & -0.034 & $* * *$ & 0.013 \\
\hline wto_ftanumbers & 1.245 & & 0.894 & -0.040 & & 0.049 \\
\hline hf_os & -0.008 & & 0.026 & & & \\
\hline db_tab_dtf & 0.010 & & 0.013 & & & \\
\hline db_sb_dtf & & & & 0.000 & & 0.000 \\
\hline hf_ffc & & & & 0.002 & $* * *$ & 0.001 \\
\hline hf_ff & & & & -0.003 & $* * *$ & 0.003 \\
\hline db_sb_timedays & & & & 0.000 & $*$ & 0.000 \\
\hline wef_gci_lsquality & & & & -0.002 & & 0.017 \\
\hline wef_gci_ebf & & & & 0.005 & & 0.016 \\
\hline gdpppp_o & 0.572 & $* * *$ & 0.140 & 0.214 & $* * *$ & 0.041 \\
\hline gdpppp_d & -0.285 & & 0.303 & 0.026 & $* * *$ & 0.010 \\
\hline gdppercapita_ppp & 1.497 & $* * *$ & 0.338 & 0.000 & & 0.000 \\
\hline bis_reer_brazil & -0.007 & & 0.013 & -0.008 & $* *$ & 0.004 \\
\hline Distance & -0.265 & & 0.441 & -0.042 & & 0.026 \\
\hline gdp_var & & & & -1.592 & & 1.172 \\
\hline Inflation & & & & 0.139 & $* *$ & 0.057 \\
\hline _cons & 0.000 & & 0.000 & 0.000 & & 0.000 \\
\hline $\mathrm{AB}$ test $\mathrm{AR}(1)$ & 0.000 & & & 0.039 & & \\
\hline $\mathrm{AB}$ test $\mathrm{AR}(2)$ & 0.169 & & & 0.190 & & \\
\hline R-square robust & 0.712 & & & 0.563 & & \\
\hline Observações & 1.288 & & & 1.067 & & \\
\hline
\end{tabular}

${ }^{*} \mathrm{p}<0.1 ; * * \mathrm{p}<0.05 ; * * * \mathrm{p}<0.01$

${ }^{1}$ Erro padrão robusto

Fonte: Elaborado pela autora

No resultado da Tabela 9 pode-se observar que o modelo separa a variável APEI em duas formas. Na primeira ele compara o coeficiente da APEI para aquelas que têm escritório próprio em relação aquelas com escritório no consulado do país de origem no país hospedeiro. 
Aqui o coeficiente apresentado no modelo de importação é negativo, mas não significativo, ou seja, apenas indica que as agências com escritório próprio não são mais eficientes do que as que têm escritório no consulado. Por outro lado, no modelo de saída de IDE, apesar de não significativo, o coeficiente é positivo, o que indica que as agências com escritório próprio são mais eficientes do que aquelas localizadas no consulado do país de destino do capital, no que se refere à atração de IDE. O modelo ainda compara o resultado de a APEI estar ausente em relação à APEI no consulado. Neste caso, os dois coeficientes foram negativos, o que indica que a presença da APEI é mais eficiente do que não ter a APEI. Contudo, neste caso a variável também não se mostrou significativa.

A Figura 44 apresenta o resultado do teste da hipótese H5b para cada um dos modelos analisados.

\begin{tabular}{|l|l|l|}
\hline \multicolumn{1}{|c|}{ Fluxo } & \multicolumn{1}{|c|}{ Hipóteses } & \multicolumn{1}{c|}{ Resultados } \\
\hline $\begin{array}{l}\text { Importação } \\
\text { (H5bI) }\end{array}$ & $\begin{array}{l}\text { O impacto de APEIs com escritório independente no fluxo de importação } \\
\text { brasileiro do país de origem da APEI é maior do que o de APEIs com } \\
\text { escritórios dentro de consulados. }\end{array}$ & Rejeitada. \\
\hline $\begin{array}{l}\text { IDE saída } \\
\text { (H5bII) }\end{array}$ & $\begin{array}{l}\text { O impacto de APEIs com escritório independente no fluxo de saída do } \\
\text { IDE do Brasil para o país de origem da APEI é maior do que o de APEIs } \\
\text { com escritórios dentro de consulados. }\end{array}$ & Rejeitada. \\
\hline
\end{tabular}

Figura 43 - Resultado para a hipótese H5b

Fonte: Elaborado pela autora

A hipótese H5c também tem a intenção de verificar o impacto da autonomia sobre o resultado das APEIs. Para isso, estabeleceu-se como critério de avaliação da autonomia se as agências estão subordinadas a presidência ou a um ministério. A Tabela 10 apresenta o resultado do modelo de painel dinâmico para a análise da diferença de resultado ocasionado pelas diversas estruturas organizacionais das agências, no que se refere a subordinação da agência, que pode responder direto à presidência ou a um ministério. 
Tabela 10 - Modelos de painéis dinâmicos para o efeito das diferenças de subordinações das agências sobre os fluxos entre os países

\begin{tabular}{|c|c|c|c|c|c|c|}
\hline \multirow[b]{3}{*}{ L.import } & \multicolumn{3}{|c|}{$\begin{array}{c}\text { XXXIII } \\
\text { Importação }\end{array}$} & \multicolumn{3}{|c|}{$\begin{array}{l}\text { XXXIV } \\
\text { IDE saída }\end{array}$} \\
\hline & \multicolumn{2}{|c|}{ Coef. } & \multirow{2}{*}{$\begin{array}{l}\text { SD } \\
0.030\end{array}$} & \multicolumn{2}{|c|}{ Coef. } & \multirow[t]{2}{*}{ SD } \\
\hline & 0.941 & $* * *$ & & & & \\
\hline L.loginvestout & & & & 0.087 & & 0.099 \\
\hline $\begin{array}{l}\text { APEI subordinada a um ministério em relação } \\
\text { à APEI subordinada a presidência }\end{array}$ & -0.008 & & 0.049 & -0.758 & $* * *$ & 0.291 \\
\hline wto_ptanumbers & 0.055 & $* * *$ & 0.021 & -0.140 & $* *$ & 0.055 \\
\hline wto_ftanumbers & -0.016 & & 0.081 & -0.319 & $* *$ & 0.157 \\
\hline hf_os & -0.005 & & 0.003 & & & \\
\hline db_tab_dtf & 0.002 & & 0.002 & & & \\
\hline $\mathrm{db} s \mathrm{~s}-\mathrm{dtf}$ & & & & 0.003 & & 0.007 \\
\hline hf_ffc & & & & 0.008 & & 0.006 \\
\hline hf_ff & & & & 0.008 & & 0.006 \\
\hline db_sb_timedays & & & & -0.006 & & 0.005 \\
\hline wef_gci_lsquality & & & & 0.048 & & 0.088 \\
\hline wef_gci_ebf & & & & -0.017 & & 0.117 \\
\hline gdpppp_o & 0.030 & & 0.031 & -0.269 & $* * *$ & 0.065 \\
\hline gdpppp_d & -1.470 & $* * *$ & 0.036 & 0.371 & $* * *$ & 0.029 \\
\hline gdppercapita_ppp & 0.211 & & 0.130 & 0.000 & $* *$ & 0.000 \\
\hline bis_reer_brazil & 0.201 & $* * *$ & 0.012 & 0.046 & $* * *$ & 0.016 \\
\hline Distance & -0.053 & $* *$ & 0.023 & -0.617 & $* * *$ & 0.096 \\
\hline gdp_var & & & & -7.267 & $*$ & 3.758 \\
\hline Inflation & & & & 0.144 & & 0.097 \\
\hline _cons & & & & & & \\
\hline AB test $\mathrm{AR}(1)$ & 0.034 & & & 0.014 & & \\
\hline $\mathrm{AB}$ test $\mathrm{AR}(2)$ & 0.170 & & & 0.327 & & \\
\hline R-square robust & 0.991 & & & 0.768 & & \\
\hline Observações & 110 & & & 83 & & \\
\hline
\end{tabular}

${ }^{*} \mathrm{p}<0.1 ; * * \mathrm{p}<0.05 ; * * * \mathrm{p}<0.01$

${ }^{1}$ Erro padrão robusto

Fonte: Elaborado pela autora

No resultado da tabela 10 pode-se observar que a análise será feita através do coeficiente da variável que compara o impacto da APEI subordinada a um ministério em relação à APEI subordinada à presidência. Nos dois modelos o coeficiente foi negativo, o que indica que a APEI subordinada a um ministério tem um impacto menor do que aquelas subordinadas à presidência. Apesar de o resultado não ser significante no modelo de importação (XXXIII), para o modelo de saída de IDE a variável é significativa.

A Figura 45 apresenta o resultado do teste da hipótese H5c para cada um dos modelos analisados. 


\begin{tabular}{|l|l|l|}
\hline Fluxo & Hipóteses & Resultados \\
\hline $\begin{array}{l}\text { Importação } \\
\text { (H5cI) }\end{array}$ & $\begin{array}{l}\text { O impacto de APEIs subordinadas a ministérios no fluxo de importação } \\
\text { brasileiro do país de origem da APEI é menor do que o de APEIs } \\
\text { subordinadas à presidência. }\end{array}$ & Rejeitada. \\
\hline $\begin{array}{l}\text { IDE saída } \\
\text { (H5cII) }\end{array}$ & $\begin{array}{l}\text { O impacto de APEIs subordinadas a ministérios no fluxo de saída de IDE } \\
\text { do Brasil para o país de origem da APEI é menor do que o de APEIs } \\
\text { subordinadas à presidência. }\end{array}$ & Aceita. \\
\hline
\end{tabular}

\section{Figura 44 - Resultado para a hipótese H5c}

Fonte: Elaborado pela autora

\subsection{Discussão dos resultados}

A pesquisa foi construída em torno da elaboração de um framework teórico da competitividade internacional de um país e da importância da internacionalização das suas empresas, identificando-se os determinantes e as dificuldades nesse processo, bem como o papel estratégico das agências. Tal etapa foi fundamental para a elaboração desta tese, uma vez que proporcionou o referencial teórico necessário às sugestões de hipóteses que permitissem avaliar o impacto da presença das referidas agências na internacionalização das empresas.

Como analisado na seção 2.5 , em sua dimensão voltada ao apoio informacional e assistência técnica que visam melhorar o ambiente de negócios no país de acolhimento, as agências oferecem suporte e podem ser vistas como instrumentos de auxílio para a internacionalização das empresas.

Nestes termos, ao se verificar as teorias de internacionalização das empresas em paralelo às teorias de custos de transações, visão baseada em recursos e visão baseada em conhecimento, construiu-se um suporte teórico para a análise do papel das agências que direcionaram a pesquisa e a formulação das hipóteses.

Primeiramente, buscou-se verificar se a presença da agência do país de origem no país hospedeiro sobre os fluxos do país de origem para o país hospedeiro apresenta impacto. Para isso, consideraram-se os fluxos comerciais e de investimento direto entre o Brasil e os demais países da amostra. Utilizou-se para a análise estatística o modelo de painel dinâmico com efeito fixo.

Dos modelos testados nesta hipótese, a presença da agência teve significância estatística para os fluxos comerciais brasileiros, ou seja, exportação e importação. Os resultados descortinaram questões interessantes. Primeiramente, verificou-se no modelo que, para importação, no tocante às agências de países de origem no Brasil, o coeficiente da 
presença da agência dessas agências é maior do que o coeficiente de presença da APEX Brasil nos fluxos de exportação brasileiros, o que leva à suposição de que as demais agências têm um impacto maior que a APEX Brasil nos fluxos comerciais brasileiros. Outro achado deste modelo foi que a presença das agências do país de origem no país hospedeiro não se mostrou estatisticamente significativa para os fluxos de IDE do país de origem para o país hospedeiro.

Interessante observar duas coisas acerca dos achados deste modelo: em primeiro lugar, que a associação com a presença das agências foi positiva, sugerindo que, quando presentes, os fluxos são maiores; e, em segundo lugar, que a presença foi estatisticamente significante apenas nos fluxos comerciais.

Os resultados acima remetem ao fato de que, conforme a teoria comportamentalista, o processo de internacionalização ocorre gradualmente, uma vez que existem diferenças culturais e distância psicológica entre o exportador, por um lado, e o mercado a ser conquistado, por outro. Essas diferenças ou distâncias geram incertezas sobre os resultados das transações, as quais só podem ser diminuídas pelo conhecimento da outra cultura. No processo de IDE, supõe-se que as empresas já tenham adquirido certo conhecimento do outro país, o que poderia justificar menor destaque da agência nesse processo específico.

Já os modelos de painéis dinâmicos para a presença da agência do país de origem no país hospedeiro sobre os fluxos do país hospedeiro para o país de origem mostraram significância estatística nos fluxos de importação e de saída de IDE. Isso implica que a presença da APEX Brasil em outros países levou a um aumento da importação brasileira desses países. Outro achado importante é que a presença das agências de outros países no Brasil levou a um aumento do fluxo de IDE brasileiro nestes países. Esse efeito indica que as agências de atração de investimento de outros países conseguem, de certa maneira, cumprir seu papel de atração de investimento. Já a presença da APEX Brasil em outros países, apesar de não atrair IDE para o Brasil, ao estar presentes e ser um ponto de referência do país, acabam aumentando o fluxo comercial entre os mesmos.

Aspecto relevante a se destacar dos modelos discutidos anteriormente é a significância estatística das variáveis de características do ambiente institucional, as quais indicam a relevância do ambiente institucional para os fluxos comerciais e de investimentos.

No caso dos modelos que avaliam a aprendizagem das agências sobre os fluxos, apenas os modelos de fluxos comerciais para a presença da agência do país de origem no país hospedeiro sobre os fluxos do país de origem para o país hospedeiro, a aprendizagem da agência mostrou-se estatisticamente significante. Esse coeficiente indica um ganho de 
aprendizagem ao longo do tempo, sendo o impacto da aprendizagem maior nos primeiros anos da presença da agência.

Nos modelos de interação da presença da agência com a distância cultural entre os países, o resultado esperado era o de que a agência reduzisse o efeito negativo da distância cultural sobre os fluxos. Conforme os resultados apresentados, o coeficiente da distância cultural foi negativo, como esperado pelo levantamento teórico. Nos fluxos de exportação e importação, a interação da agência reduziu o efeito negativo da distância cultural sobre os fluxos comerciais, mesmo sendo significativo estatisticamente apenas para o resultado do fluxo de importação. Contudo, contrário ao esperado, nos fluxos de investimento direto, a presença da agência acentuou o efeito negativo da distância cultural. Esse resultado foi estatisticamente significativo para os fluxos de saída de IDE brasileiro. Os gráficos de interação demonstram que, nos casos dos modelos de IDE, a presença da agência diminui o efeito da distância cultural para países com pouca distância cultural, porém acentuam quando a distância cultural é maior. Isso pode indicar que os investidores, através da presença da agência, identificam países com menor distância cultural aumentando seus fluxos para os mesmos e reduzindo para aqueles que percebem como mais distantes e nos quais poderiam enfrentar maior dificuldade de adaptação.

Nos modelos de interação da presença da agência com a distância geográfica, o resultado observado foi uma surpresa. Apesar de a distância geográfica apresentar coeficiente negativo em todos os modelos, a variável não foi estatisticamente significativa, o que difere do esperado pela teoria. A variável de interação da presença da agência com a distância geográfica foi significativa apenas para o modelo de importação. A análise do gráfico da interação para o fluxo de importação mostra que para as maiores distâncias, a presença da agência levou a um aumento do fluxo em relação à curva na qual a agência não estava presente. Entretanto, o resultado para os países de menor distância geográfica foi o oposto, ou seja, a presença da agência diminuiu o fluxo.

Os últimos modelos testados foram para hipóteses sobre as diferentes características das agências nos impactos das mesmas. Nos modelos de painéis dinâmicos que verificaram os diferentes impactos das agências de acordo com os controles societários, ou seja, públicas ou público-privadas, apesar de o resultado não ter sido significante, a variável de comparação do impacto das APEIs público-privadas em relação à pública foi positiva, o que indica que o impacto das APEIs público-privadas é maior em comparação às APEIs sem a participação do setor privado. De todo modo, vale ressalvar, novamente, que tal resultado não foi estatisticamente significante. 
Já na comparação entre a APEI pública e a ausência da APEI, o modelo de saída de IDE mostrou-se estatisticamente significante, indicando que a presença da agência tem impacto positivo sobre o fluxo de saída de IDE.

No que se refere à autonomia das APEIs, que, neste estudo, foi testada como escritório próprio, no país hospedeiro ou escritório no consulado do país de origem no país hospedeiro, pode-se dizer que o referido teste traz à tona discussão sobre a forma de entrada da APEI no país hospedeiro e seus benefícios em cada caso. Apesar de não se mostrar estatisticamente significante, o modelo desperta a atenção para a diferença dos resultados no caso do fluxo comercial (importação) e no fluxo de investimento (IDE saídas). Enquanto para o fluxo comercial o coeficiente de comparação dos dois casos sugere que o efeito da APEI com escritório no consulado é maior, no caso da saída de IDE o coeficiente indica o contrário, ou seja, para o fluxo de investimento, APEIs com escritório próprio teriam maior impacto sobe os fluxos. Aqui, convém destacar que o resultado pode ter sido estatisticamente insignificante por haver uma quantidade pequena de agências para a comparação.

O último teste realizado envolveu as formas de subordinação das agências, se em relação a ministérios ou a presidências. Apesar de o resultado não ser estatisticamente significante no fluxo comercial, para o fluxo de investimento, no caso, saída de IDE, o resultado foi significativo, indicando um efeito maior das agências subordinadas à presidência. Esse resultado atende à expectativa inicial.

Em relação às demais variáveis utilizadas nos modelos, vale destacar a significância da qualidade de fornecedores para o fluxo de IDE, bem como a significância do comportamento ético das firmas, o que indica a importância das características do ambiente institucional, de acordo com a teoria apresentada. Outro resultado interessante foi o de que a variável de acordo preferencial se mostrou significativa na maioria dos fluxos, apresentando coeficiente positivo para os fluxos comerciais, e negativos para os fluxos de investimento, ao contrário do previsto. O mesmo foi observado para os acordos de livre comércio, que apresentaram coeficiente positivo para os fluxos comerciais, porém negativos para os fluxos de investimentos. Entretanto, esta variável não se mostrou estatisticamente significante. Esperava-se que essa associação fosse positiva, uma vez que os acordos regionais promovem reduções de barreiras tarifárias e não tarifárias ao comércio. Tal inversão, porém, pode ter como origem o fato de o Brasil possuir poucos acordos regionais.

Em suma, os modelos mostraram um impacto positivo da presença da agência para os fluxos comerciais e para o fluxo de IDE do país hospedeiro para o país de origem, o que indica o poder de atração de investimento mediante a presença da agência. 


\section{CONCLUSÕES FINAIS}

Este estudo pode ser visto como uma das primeiras tentativas para examinar empiricamente o efeito da presença das agências de promoção de exportação e investimento em países em desenvolvimento.

Uma contribuição metodológica desta pesquisa foi a abordagem do problema, adotando-se um estimador de painéis dinâmicos com efeito fixo. Este modelo, com a presença de uma variável defasada, reduz potenciais vieses de variáveis omitidas que existam em um modelo estático, uma vez que alguns determinantes dos fluxos podem estar relacionados com a criação das APEIs. Assim, o uso de painel de dados, com variáveis de efeitos fixos, pode ajudar a superar parte do problema de endogeneidade, devido ao viés da variável omitida. Além disso, os dados em painéis têm uma vantagem na inferência dos parâmetros estudados, pois propicia mais graus de liberdade e maior variabilidade na amostra em comparação com dados em cross-section ou em séries temporais, o que refina a eficiência dos estimadores econométricos.

Em um nível mais amplo, uma das principais contribuições para a literatura empírica sobre o papel das APEIs em atividades comerciais transfronteiriças é que o estudo aborda tanto os fluxos de saída quanto os de entrada, além de considerar a presença das APEIs dos países de origem e de destino do fluxo, o que permitiu averiguar seu impacto intencional e "acidental", ou seja, se a agência tem a intenção de promover a exportação e acaba impactando positivamente na importação. Além disso, a pesquisa discute a relação das agências com os fluxos em um país em desenvolvimento, o Brasil, o que o relevante, dado o recente surgimento de países em desenvolvimento, como exportadores globais e origem de IDE.

APEIs têm sido ativas na promoção de atividades de negócios internacionais, principalmente na promoção de exportações e a atração de fluxos de IDE em seus países. Isso ocorre porque as exportações e entradas de IDE têm sido tradicionalmente vistas como mais benéficas para o crescimento e desenvolvimento do que as importações e saída de IDE. Refletindo essa percepção generalizada, a maioria dos estudos empíricos sobre as atividades de promoção de negócios internacionais limitam-se ao efeito das agências sobre as exportações e atração de IDE. 
Entretanto, em linha com o crescente reconhecimento dos benefícios econômicos potencialmente consideráveis de importações e saída de IDE, alguns governos também começaram a promover importações e saída de IDE.

A presente tese se propôs a investigar empiricamente o impacto da presença da APEI nos fluxos de transação entre os países, tanto sobre os fluxos de saída (exportação e investimento direto no exterior), quanto os fluxos de entrada (importação e investimento direto estrangeiro no Brasil).

De um modo geral, o balanço das evidências desse estudo indica que a presença das APEIs tem sido significativa no aumento dos fluxos comerciais e de atração de IDE. Intuitivamente, o papel das APEIs para atenuar o grande risco associado a se aventurar em mercados estrangeiros não deve ser menos pertinente para IDE do que para as exportações. A promoção de exportação e investimento é um esforço da parte dos governos para aliviar os problemas associados com a falta de informação e conhecimento sobre o novo mercado. Se as informações fornecidas pelas APEIs não forem úteis para as firmas basearem as suas decisões, não haverá relação estatística significativa entre a atuação da APEI e os fluxos comerciais e de investimentos.

Neste sentido, o estudo encontrou relação estatisticamente significante para a atuação das APEIs no mercado brasileiro e da APEX nos países hospedeiros. Os resultados empíricos encontraram um efeito positivo significativo da atuação da APEI brasileira (APEX) nos fluxos de exportação e importação brasileiras. Esse resultado apoia a questão de que as agências funcionam como redutores de custos de transação, reduzindo as incertezas em relação aos mercados desconhecidos, o que leva a um aumento dos fluxos comerciais. Em relação à presença da APEI de outros países no Brasil, os resultados significativos foram nos fluxos de importações brasileiras e IDE brasileiro no exterior, o que indica que elas cumprem seu papel de estimular as exportações e atrair IDE para seus mercados internos. Ou seja, os resultados sugerem que a presença das APEIs dos países de origem dos fluxos de importação brasileiras e acolhimento do IDE brasileiro têm um impacto positivo sobre os fluxos brasileiros.

Quando observamos o coeficiente da presença das agências, nota-se que o coeficiente das APEIs é maior do que o coeficiente da APEX, o que sugere uma atuação mais eficiente das APEIs de outros países no mercado brasileiro do que da APEX nos países de acolhimento.

Em relação à atuação da agência ao longo do tempo, utilizado como uma proxy de aprendizagem, os resultados encontrados foram estatisticamente significantes na atuação das agências nos países hospedeiros para os fluxos comerciais. Nestes casos, o coeficiente foi 
positivo, indicando um ganho de aprendizagem ao longo do tempo. Aqui, vale ressaltar que o estudo mostrou um ganho maior nos primeiros anos de atuação.

Além disso, se a promoção à exportação e ao investimento é um canal eficaz de aliviar as assimetrias de informação, deve ser mais eficaz no caso de países onde a informação é mais difícil de se obter. $\mathrm{O}$ estudo considerou a distância cultural e a distância geográfica como proxies para a assimetria de informações. No caso da distância geográfica, o efeito positivo da agência sobre o impacto negativo da distância nos fluxos foi verificado. Apesar de não ter se mostrado estatisticamente significante, o coeficiente de interação foi positivo. Ao fazer a análise da interação da atuação da APEIs com a distância cultural, verificou-se que a presença das agências reduz o efeito negativo da distância, o que indica, mais uma vez, seu papel sobre a redução de incertezas. Já em relação à distância geográfica os resultados foram ambíguos, aparecendo tanto o efeito positivo, quanto negativo.

No geral, a variável de distância cultural apresentou coeficiente negativo, indicando que quanto maior a distância menor os fluxos.

O estudo indica, ainda, que há diferenças no efeito das agências dependendo das distâncias culturais. Quanto maior a distância entre os países, maior o impacto do deslocamento da curva sobre os fluxos comerciais e de investimento. Isso implica que a APEI pode ajudar as empresas de seus países a se internacionalizarem, seja por meio da exportação, ou de investimentos diretos para países culturalmente mais distantes, fornecendo-lhes informação local e suporte relevante. A presença da agência de seus países de origem também pode dar um sentido psicológico de segurança para os investidores que se aventuram em mercados arriscados e incertos.

No que tange às diferenças nas estruturas organizacionais das agências, apesar de o resultado não ter sido estatisticamente significante, os coeficientes indicam que agências com a participação de capital privado são mais eficientes do que as de capital público, tanto no estímulo à exportação do país para o Brasil quanto na atração de investimento brasileiro. $\mathrm{O}$ estudo mostrou que há indicios de que os fluxos de IDE são expressivamente mais baixos nos países onde a APEI é de capital público em contraste a ser uma instituição público-privada. Esses achados indicam que as APEIs se beneficiam da visibilidade e da participação do setor privado por meio de seus conselhos ou das relações institucionais. Também sugerem que o setor privado contribui para ampliar a plataforma e ajudar a alcançar um consenso no esforço da APEI para o mercado do país no exterior. Em muitos aspectos, a promoção de exportação e investimento se encaixa na descrição de uma atividade do governo que poderia se beneficiar ao contratar o setor privado. 
Apesar de requerer financiamento do governo por causa da discrepância entre o lucro privado e benefício social, o que nesse sentido, é uma função pública, algumas tarefas exigem conhecimentos de mercado que poderiam, talvez, ser mais rentáveis por meio de concorrência no mercado.

O mesmo é observado em relação a quem a APEI está subordinada, ou se reporta. Apesar de não terem se mostrado estatisticamente significativos, os resultados sugerem que o efeito da APEI é maior quando esta se reporta diretamente ao presidente de um país do que quando se reporta a um ministério. O mecanismo de se reportar para o presidente ou para um ministério pode refletir o compromisso global do governo com as políticas de internacionalização.

Em relação à autonomia da agência, analisada pela proxy de se ter um escritório independente ou estar vinculada ao consulado do país de origem no país de acolhimento, notam-se resultados diferentes no caso do estímulo à exportação e à atração de investimento. Para o estimulo à exportação, o resultado indica que uma agência com escritório no consulado apresenta impacto mais expressivo do que aquelas com escritórios independentes. Já, para a atração de IDE, o resultado foi o contrário, sugerindo que as agências com escritório próprio atraem mais IDE do que aquelas localizadas em consulados.

No que se refere às agências estarem subordinadas à presidência do país ou a um consulado, os resultados não divergem. Tanto para a promoção de exportação quanto para a promoção de investimento, aquelas subordinadas diretamente à presidência apresentam um efeito maior. Vale ressaltar que, apesar de o resultado para a exportação não ser significante, no caso da atração de IDE, foi estatisticamente significante.

Com isso, pode-se afirmar que a visibilidade política e a participação do setor privado parecem ser dois elementos que contribuem para o desempenho das APEIs.

Além da presença das agências, os modelos indicaram características institucionais que se mostram relevantes e significativas para os fluxos comerciais e de investimento, como a abertura comercial, liberdade de corrupção, comportamento ético das firmas e acordos preferenciais. A qualidade de fornecedores também se mostrou relevante, o que pode ser interpretado tanto na busca de fornecedores quanto para aumentar a competitividade da empresa. Isso mostra a importância de um bom ambiente institucional, a fim de se obter maior êxito na internacionalização das empresas e atração de investimento.

Em vista disso, as APEIs devem tentar trabalhar com os seus governos na elaboração de políticas destinadas a melhorar o clima de negócios em seus países, o que fortalece não apenas a atuação no ambiente internacional, mas também a competitividade do país. 
O resultado dos coeficientes das variáveis de presença da agência brasileira (APEX Brasil) e das APEIs presentes no mercado brasileiro sobre os fluxos comerciais e de saída de IDE gera importante questionamento. Tais coeficientes indicam um impacto maior das agências dos outros países no mercado brasileiro, o que implica necessária reflexão sobre o que poderia ser feito de forma diferente pela APEX Brasil.

Além disso, os resultados levam a uma série de implicações e questionamentos políticos, como, por exemplo, a importância da participação privada para um melhor resultado da APEI e a instalação em escritório próprio ou em consulados nos países hospedeiros. O estudo indica a necessidade de se observar com mais detalhes se o gasto com escritórios independentes de consulados nos países hospedeiros não se justificam em razão do melhor resultado das agências na atração de IDE, além de sugerir atenção redobrada ao ambiente institucional no qual a agência será localizada, para que a sua atuação tenha o efeito desejado.

\subsection{Limitações da pesquisa e possibilidades de estudos futuros}

Inúmeras foram as limitações enfrentadas para a realização desta pesquisa, contudo, a maior delas esteve na dificuldade para a obtenção de dados que permitissem as análises. Além da dificuldade da obtenção de alguns dados macroeconômicos, informações sobre as agências não são facilmente encontradas.

Apesar de contar com uma extensa relação de países, os dados foram analisados sempre com o Brasil sendo uma das pontas do fluxo, o que pode limitar o resultado da pesquisa aos fluxos do Brasil, mesmo considerando que foram analisados dados com agências de 20 países, incluindo a agência brasileira.

Assim, para estudos futuros seria interessante a construção de um painel de dados mais extenso e que envolvesse um número maior de países base na análise. Isso permitiria uma generalização dos dados encontrados. Ademais, futuramente seria importante a realização de estudo que verificasse se o impacto da atuação da agência difere de setor para setor, por tamanho de empresa e por tipo de atividade, o que auxiliaria na identificação do benefício social gerado pela agência.

Estudo comparando o budget das agências com seus desempenhos, também serviriam de orientação para a definição dos bugets dos governos que deveriam ser destinados a essas atividades. Além disso, a interação da presença da agência com diferentes características institucionais de países hospedeiros possibilitaria melhor orientação das características 
institucionais que devem ser analisadas na decisão de se instalar a agência em determinado pais.

Outra possibilidade seria uma pesquisa que verificasse se a presença da agência impacta sobre o modo de internacionalização das empresas, ou seja, exportação, IDE e formas intermediárias através de contratos. Se a agência atua como redutor dos custos de transação, seria esperado que a presença das agências aumentasse a internacionalização formas intermediárias, de forma mais acentuada do que o aumento da exportação e do IDE.

Outra direção que também poderia ser considerada é a avaliação da ênfase dada pelas agências na atração de qualidade ou quantidade de IDE, o que pode estar diretamente associado ao interesse na criação de emprego, exportações ou transferências de tecnologia associados aos fluxos de IDE.

Por fim, também seria interessante a realização de estudos de casos individuais, com foco em algumas agências, dando-se atenção às suas características internas e ambiente externo, avaliando-se as técnicas promocionais específicas, alémdas diferentes estruturas, o que poderia aumentar o conhecimento sobre os efeitos das estruturas nas diferentes formas de atuação. 


\section{REFERÊNCIAS BIBLIOGRÁFICAS}

Adler, N. J., \& Jelinek, M. (1986). Is "organization culture" culture bound?, Human Resource Management, 25(1), 73-90.

Aharoni, Y. (1966). The foreign investment decision process. The Int. Exec. The International Executive, 8(4), 13-14. doi:10.1002/tie.5060080407

Ahearne, A. G., Griever, W. L., \& Warnock, F. E. (2004). Information costs and home bias: an analysis of US holdings of foreign equities. Journal of international economics, 62(2), 313-336.

Alchian, A. A., \& Demsetz, H. (1972). Production, Information Costs, and Economic Organization. American Economic Review.

Alem, A. C., \& Cavalcanti, C. E. (2005). O BNDES e o Apoio à Internacionalização das Empresas Brasileiras: Algumas Reflexões. Revista do BNDES, Rio de Janeiro, 12 (24), 43-76.

Aliber, R. Z. (1970). A theory of direct of direct foreign investment. In C. P. Kindleberger (Org). The international corporation: a symposium. Cambridge: MIT Press.

Almeida, A. L. S. (2007). A relevância do investimento brasileiro direto no exterior para as empresas e para a sociedade. In A. L. S. Almeida (Org.). Internacionalização de empresas brasileiras: Perspectivas e Riscos. Rio de Janeiro: ELSEVIER.

Almeida, R. M., \& Lara, J. E. (2010). Estratégias de Internacionalização na Siderurgia: o caso CST-USINOR-ARCELOR. FACEF Pesquisa-Desenvolvimento e Gestão, 8(2).

Alvarez, R., \& Crespi, G. T. (2000). Exporter Performance and Promotion Instruments: Chilean Empirical Evidence. Estudios De Economía, 27(2), 225-241.

Anderson, E. (1990). Two Firms, One Frontier: On Assessing Joint Venture Performance. Sloan Management Review, 34 (2), 19-30.

Anderson, J. E., \& Wincoop, E. V. (2003). Gravity with Gravitas: A Solution to the Border Puzzle. American Economic Review, 93(1), 170-192. Doi: 10.1257/000282803321455214

Anderson, J. E., \& Wincoop, E. V. (2004). Trade Costs. Journal of Economic Literature, 42(3), 691-751. Doi: 10.1257/0022051042177649

Andrews-Johnson, K., \& Morisset, J. (2004). The Effectiveness of Promotion Agencies at Attracting Foreign Direct Investment. Doi: 10.1596/0-8213-5606-2

Ansoff, H. I., \& McDonnell, E. J. (1993). Implantando a administração estratégica. São Paulo: Atlas. 
Appleyard Jr, D. R. i AJ Field Jr. (1998). International Economics, Third Edition, Irwin McGraw-Hill, SL.

Arbix, G., Salerno, M. S., \& De Negri, J. A. (2004). Inovação, via internacionalização, faz bem para as exportações brasileiras. Brasília: IPEA.

Arellano, M., \& Bond, S. (1991). Some Tests of Specification for Panel Data: Monte Carlo Evidence and an Application to Employment Equations. The Review of Economic Studies, 58(2), 277. Doi: 10.2307/2297968

Arellano, M., \& Stephen, R. B. (1998). Dynamic Panel Data Estimation Using DPD98 for Gauss: A Guide for Users.

Arellano, M., \& Bover, O. (1995). Another look at the instrumental variable estimation of error-components models. Journal of Econometrics, 68(1), 29-51. Doi: 10.1016/03044076(94)01642-d

Arino, A., Ghemawat, P., \& Ricart, J. E. (2004). Creating Value through International Strategy. Palgrave Macmillan. Doi: 10.1057/9780230005563

Arnold, D. J., \& Quelch, J. A. (1998). New strategies in emerging markets. MIT Sloan Management Review, 40(1), 7.

Azevedo, D. B. (2001). Os acordos para a promoção e a proteção recíproca de investimentos assinados pelo Brasil. Estudo Técnico da Consultoria Legislativa da Câmara dos Deputados. Brasilia: Câmara dos Deputados.

Baier, S. L., \& Bergstrand, J. H. (2007). Do free trade agreements actually increase members' international trade?. Journal of international Economics, 71(1), 72-95.

Baldwin, R., \& Taglioni, D. (2006). Gravity for dummies and dummies for gravity equations (No. w12516). National Bureau of Economic Research.

Baltagi, B. (2005). Econometric analysis of panel data. John Wiley \& Sons.

Barkema, H. G., Bell, J. H., \& Pennings, J. M. (1996). Foreign entry, cultural barriers, and learning. Strategic management journal, 17(2), 151-166.

Barney, J. B. (1991). Firm resources and sustained competitive advantage.Journal of management, 17(1), 99-120.

Barney, J. B. (1995). Looking inside for competitive advantage. The Academy of Management Executive, 9(4), 49-61.

Barney, J. B. (2002). Gaining and Sustaining Competitive Advantage. New Jersey: Prentice Hall. 
Barney, J. B., \& Clark, D. N. (2007). Resource-based theory: Creating and sustaining competitive advantage. Oxford University Press on Demand.

Barney, J.B., \& Hesterly, W. (1999). Economia das Organizações: entendendo a relação entre as organizações e a análise econômica. In S. R. Clegg, C. E. Hardy, \& W. R. Nord, (Orgs.). Handbook De Estudos Organizacionais. São Paulo: Atlas.

Barral, W. (2011). Prefácio. In L. Acyoli, L. A. F. Lima, \& E. Ribeiro, (Orgs.). Internacionalização de empresas: experiências internacionais selecionadas. Brasília: Ipea.

Basi, R. S. (1963). Determinants of United States private direct investments in foreign countries. Kent State University.

Baskerville, R. F. (2003). Hofstede never studied culture. Accounting, organizations and society, 28(1), 1-14.

Beckerman, W. (1956). Distance and the pattern of intra-European trade. The review of Economics and Statistics, 31-40.

Bergsten, C. F., Horst, T., \& Moran, T. H. (1978). American multinationals and American interests. Washington, $D C$.

Berry, H., Guillén, M. F., \& Zhou, N. (2010). An institutional approach to cross-national distance. Journal of International Business Studies, 41(9), 1460-1480.

Bevan, A., Estrin, S., \& Meyer, K. (2004). Foreign investment location and institutional development in transition economies. International business review, 13(1), 43-64.

Bjorkman, I., \& Furu, P. (2000). Determinants of variable pay for top managers of foreign subsidiaries in Finland. International Journal of Human Resource Management, 11(4), 698713.

Blejer, M. I., \& Khan, M. S. (1984). Government policy and private investment in developing countries. Staff Papers, 31(2), 379-403.

Blomstermo, A., \& Sharma, D.D. (Orgs.) (2003). Learning in the internationalization process of firms.

Blomstermo, A., \& Sharma, D. D. (2003). Three decades of research on the internationalization process of firms. In A. Blomstermo, \& D. D. Sharma (Org.). Learning in the internationalisation process of firms. Cheltenham, UK: Edward Elgar.

Blundell, R., \& Bond, S. (1998). Initial conditions and moment restrictions in dynamic panel data models. Journal of econometrics, 87(1), 115-143. 
Boddewyn, J. J. (1985). Theories of foreign direct investment and divestment: A classificatory note. Management International Review, 57-65.

Boddewyn, J. J. (1992). Political Behavior Research. In P. J. Buckley, (Org.). New Directions in International Business. Cheltenham: Edward Elgar.

Boisot, M. H. (1998). Knowledge assets: Securing competitive advantage in the information economy. OUP Oxford.

Boone, L. E.; \& Kurtz, D. L. (1998). Contemporary Marketing. Orlando: The Dryden.

Borini, F. M., Fleury, M. T. L., Fleury, A. C. C., \& Oliveira Jr, M. M. (2010). Performance e internacionalização das empresas brasileiras. Multinacionais brasileiras: internacionalização, inovação e estratégia global. Porto Alegre: Bookman, 1, 111-126.

Boyacigiller, N. (1990). The role of expatriates in the management of interdependence complexity and risk in multinational corporations. Journal of International Business Studies, 21(3), 357-381. Doi: 10.2307/154951

Boyacigiller, N. A., Kleinberg, J., Phillips, M. E., \& Sackmann, S. (2007). Conceptualizing culture: elucidating the streams of research in international cross-cultural management. In B. J. Punnett \& O. Shenkar (Orgs.), Handbook for international manegement research (2nd ed), 99-167. Ann Arbor: The University Of Michigan Press.

Bradley, F. (1995). International Marketing Strategy. London: Prentice-Hall International (2nd ed). Prentice Hall.

Brasil, H. V., Arruda, C.A., Leonel, J.N., \& Goulart, L. (1996). Pesquisa De Campo Sobre A Internacionalizacao Das Empresas. In: Brasil, H. V., \& Arruda, C. (Eds.). Internacionalização De Empresas Brasileiras. Rio De Janeiro: Qualitymark.

Brasil, H. V., \& Arruda, C.A. (1996). Internacionalização De Empresas Brasileiras. Rio De Janeiro: Qualitymark.

Brasil, H.V.; Arruda, C. A.; \& Goulart, L. (1994). A evolução na dinâmica de internacionalização. Revista Brasileira de Comércio Exterior, 31-40.

Bresser-Pereira, L. C. (2006). Estratégia nacional e desenvolvimento. Revista De Economia Política. 203-230

Brewer, P. A. (2007). Operationalizing psychic distance: A revised approach.Journal of International Marketing, 15(1), 44-66.

Brouthers, L. E., Brouthers, K. D., \& Werner, S. (2000). Perceived environmental uncertainty, entry mode choice and satisfaction with EC-MNC performance. British Journal of Management, 11(3), 183-195. 
Buckley, P. J. (1998). Government policy responses to strategic rent-seeking transnational firms. In P. J. Buckley, (Org.). International strategic management and government policy. New York: St. Martin's Press.

Buckley, P. J. (2002). Is the international business research agenda running out of steam?. Journal of international business studies, 33(2), 365-373.

Buckley, P. J., \& Casson, M. (1988). Models of the multinational enterprise. Journal of international business studies, 21-44.

Buckley, P. J., \& Casson, M. (2002). The Future of the Multinational Enterprise 25th Anniversary. Doi: 10.1057/9780230371798

Buckley, P. J., \& Casson, M. C. (2009). The internalisation theory of the multinational enterprise: A review of the progress of a research agenda after 30 years. Journal of International Business Studies J Int Bus Stud, 40(9), 1563-1580. doi:10.1057/jibs.2009.49

Buckley, P. J., Casson, M., \& Gulamhussen, M. (2002). Internationalisation - real options, knowledge management and the Uppsala approach. In V. Havila, M. Forsgren, \& H. Håkansson, (Orgs.). Critical perspectives on internationalisation. 229-261.

Bukowitz, W. R., \& Williams, R. L. (2002). Manual de gestão do conhecimento: ferramentas e técnicas que criam valor para a empresa. Bookman.

Camilo, S. P. O., Marcon, R., \& Bandeira-de-Mello, R. (2012). Conexões políticas das firmas e seus efeitos na performance: uma convergência entre as perspectivas da governança e da dependência de recursos-um ensaio teórico. Revista Alcance, 19(2), 241-258.

Castells, M. (1999). A era da informação: economia, sociedade e cultura (Vol. 1). Paz e terra.

Caves, R. E. (1996). Multinational enterprise and economic analysis. Cambridge university press.

Cavusgil, S. T. (1980). On the internationalization process of firms. European research, 8(6), 273-281.

Chandler, A. D. (1992). Organizational capabilities and the economic history of the industrial enterprise. The Journal of Economic Perspectives, 6(3), 79-100.

Charlton, A., \& Davis, N. (2007). Does Investment Promotion Work?. The BE Journal of Economic Analysis \& Policy, 7(1).

Chen, H., \& Chen, T. J. (1998). Network linkages and location choice in foreign direct investment. Journal of international business studies, 29(3), 445-467.

Chen, M. X., \& Moore, M. O. (2010). Location decision of heterogeneous multinational firms. Journal of International Economics, 80(2), 188-199. 
Christiansen, H. (2003). Checklist for foreign direct investment incentive policies. Oecd

Chudnovsky, D., \& López, A. (2000). A third wave of FDI from developing countries: Latin American TNCs in the 1990s. Transnational Corporations, 9(2), 31-74.

Cintra, R., \& Mourão, B. (2005). Perspectivas e estratégias na internacionalização de empresas brasileiras. Revista Autor, São Paulo, Ano, 5.

Coase, R. H. (1937). The nature of the firm. Economica, 4(16), 386-405.

Coase, R. H. (1960). The problem of social cost. In Classic Papers in Natural Resource Economics (pp. 87-137). Palgrave Macmillan UK.

Coelho, D. B. (2014). Empresas e governo no contexto da economia global: o papel do governo brasileiro na internacionalização das empresas brasileiras de bens de capital mecânicos (Tese de Doutorado, Universidade de São Paulo).

Coelho, D. B., \& Junior, M. D. M. O. (2016). A internacionalização de empresas na agenda governamental contemporânea de desenvolvimento: reflexões críticas e analíticas para os negócios internacionais. Cadernos EBAPE. BR, 14, 527.

Coluchi, A. (2011). Promoção de exportações brasileiras: avaliação de desempenho. Universidade de São Paulo

Contractor, F. J. (1981). The role of licensing in international strategy. Columbia Journal of World Business, 16(4), 73-83.

Coutinho, E.S., Peixoto, F.V.L., \& Amaral, H.F. (2005): De Smith a Porter: um ensaio sobre as teorias de comércio exterior. Revista De Gestão Usp, 12(4), 101-113.

Craswell, J. W. (2007). Projeto De Pesquisa: Método Qualitativo, Quantitativo e Misto. Porto Alegre: Bookman.

Cyert, R.M., \& March, J.G. (1963). A behavioral theory of the firm. Englewood Cliffs, Nj.

Cyrino, A. B., \& Barcellos, E. P. (2006). Estratégias de internacionalização: evidências e reflexões sobre as empresas brasileiras. In: Tanure, B.; Duarte, R. G. (Orgs.). (2006): Gestão Internacional. São Paulo: Saraiva, 221-246.

Cyrino, A. B., \& Penido, E. (2007): Benefícios, riscos e resultados do processo de internacionalização das empresas brasileiras. In A. Almeida, (Org.). Internacionalização de empresas brasileiras: perspectivas e riscos. Fundação Dom Cabral, Rio De Janeiro: Elsevier.

Cyrino, A. B., Penido, E., \& Tanure, B. (2005). Trajetórias de empresas brasileiras em mercados internacionais: contribuições empíricas ao debate sobre a importância das distâncias. Caderno De Idéias. Nova Lima Fundação Cabral. 
Cyrino, A. B., Penido, E., \& Tanure, B. (2007). Estratégias de internacionalização: evidencias e reflexões sobre as empresas brasileiras. In A. Fleury, M. T. L. Fleury, (Orgs.). Internacionalização E Os Países Emergentes. São Paulo: Atlas.

Cyrino, A. B., \& Tanure, B. (2009). Trajetórias das multinacionais brasileiras: lidando com obstáculos, desafios e oportunidades no processo de internacionalização. In J. Ramsey, \& A. Almeida, (Orgs.). A Ascensão das multinacionais brasileiras: o grande salto de pesopesados regionais a verdadeiras multinacionais. Rio De Janeiro: Elsevier.

Cyrino, A. B., Oliveira Jr, M. M., \& Barcellos, E. P. (2010). Evidências sobre a internacionalização de empresas brasileiras. In M. M. Oliveira Jr., (Org.). Multinacionais Brasileiras: Internacionalização, Inovação E Estratégia Global. Porto Alegre: Bookman.

Czinkota, M. R. (1994). A National export assistance policy for new and growing business. Journal of International Marketing, 91-101.

Dakessian, L. C. (2014). Probing the effects of cultural and psychic distance on M\&A performance: the case of multilatinas' cross-border acquisitions (Doctoral dissertation, Universidade de São Paulo).

Dakessian, L. C., \& Feldmann, P. R. (2013). Multilatinas and value creation from crossborder acquisitions: an event study approach. BAR-Brazilian Administration Review, 10(4), 462-489.

Daniels, J. L., Daniels, N. C., \& Liske, L. (1996). Visão global. Makron Books do Brasil.

Davenport, T., \& Prusak, L. (1999). Conhecimento empresarial: um guia definitivo para a gestão da informação. Tradução: Lenke Peres. RJ: Campus.

De Negri, F. (2005). O perfil dos exportadores industriais brasileiros para a china. Revista Brasileira de Comércio Exterior. Rio de Janeiro: FUNCEX, 84, 22-35.

Dib, L. A. (2008). O processo de internacionalização de pequenas e médias empresas e o fenômeno Born global: estudo do setor de software no Brasil.Universidade Federal do Rio de Janeiro.

Dib, L. A., \& Carneiro, J. (2006). Avaliação comparativa do escopo descritivo e explanatório dos principais modelos de internacionalização de empresas. Anais do XXX ENANPAD. Salvador: ANPAD.

Dicken, P. (2010). Mudança global: mapeando as novas fronteiras da economia mundial. (5a ed). Porto Alegre: Bookman.

Dosi, G., Marengo, L., \& Fagiolo, G. (1996). Learning in evolutionary environments, Working paper, IIASA. 
Dow, D., \& Karunaratna, A. (2006). Developing a multidimensional instrument to measure psychic distance stimuli. Journal of international business studies, 37(5), 575-577.

Doz, Y., Santos, J. (2001). From global to metanational: How companies win in the knowledge economy. Harvard Business School Press.

Drogendijk, R., \& Slangen, A. (2006). Hofstede, Schwartz, or managerial perceptions? The effects of different cultural distance measures on establishment mode choices by multinational enterprises. International business review, 15(4), 361-380.

Dunning, J. H. (1977). Trade, location of economic activity and the MNE: A search for an eclectic approach. In The international allocation of economic activity (pp. 395-418). Palgrave Macmillan UK.

Dunning, J. H. (1980). Toward an eclectic theory of international production: Some empirical tests. Journal of international business studies, 11(1), 9-31.

Dunning, J. H. (1981). Explaining The International Direct Position Of Countries: Towards A Dynamic Or Developmental Approach. Weltwirtschaftliches Archiv, 117(1), 30-64.

Dunning, J. H. (1988). Explaining international production. London: Unwin Hyman.

Dunning, J. H. (1991). The eclectic paradigm of international production. The Nature of the Transnational Firm, 121.

Dunning, J. H. (1993). The globalization of business: the challenge of the 1990's. London: Routedge.

Dunning, J. H. (1999). Governments, globalization, and international business. Oxford University Press.

Dunning, J. H. (2000). The eclectic paradigm as an envelope for economic and business theories of MNE activity. International business review, 9(2), 163-190.

Dunning, J. H. (2001). The eclectic (OLI) paradigm of international production: past, present and future. International journal of the economics of business, 8 (2), 173-190.

Dunning, J. H. (2002). Theories and paradigms of international business activity: the selected essays of John H. Dunning (vol. 1). Edward Elgar Publishing.

Dunning, J. H. (2003). Business analytic approach to governments and globalization. In: J. H. Dunning. Governments, globalization, and international business. Oxford University Press.

Dunning, J. H., \& Lundan, S. M. (2008). Multinational enterprises and the global Economy. (2a Ed). Edward Elgar Publishing. 
Dunning, J. H., \& Narula, R. (1996). Foreign direct investment and governments. London: Routledge.

Dunning, J. H., \& Rugman, A. M. (1985). The influence of hymers's dissertation on the theory of foreign direct investment. The American Economic Review, 75(2), 228-232.

Dyer, J. H. (1997). Effective interfirm collaboration: how firms minimize transaction costs and maximize transaction value. Strategic Management Journal, 18, 535-556.

Evans, J., A., \& Mavondo, F. (2002). Psychic distance and organizational performance: an empirical examination of international retailing operations. Journal of International Business Studies, 33 (3), 515-532.

Evans, J., Treadgold, A., \& Mavondo, F. T. (2000). Psychic distance and the performance of international retailers-a suggested theoretical framework. International Marketing Review, 17(4/5), 373-391. Doi: 10.1108/02651330010339905

FDC. (2012). Ranking das transnacionais brasileiras 2012: os benefícios da internacionalização. Belo Horizonte: [S.N.].

Felin, T., \& Foss, N. J. (2005). Strategic organization: a field in search of micro-foundations. Strategic Organization, 3, 441-55.

Fenwick, M., Edwards, R., \& Buckley, P.J. (2003). Is cultural similarity misleading? The experience of australian manufacturers in britain, International Business Review 12, 297-309.

Fleury, A., \& Fleury, M. T. L. (2007). Internacionalização e os países emergentes. São Paulo: Atlas.

Fleury, A., \& Fleury, M. T. L. (2009). A evolução dos sistemas de produção globais e o surgimento das emns brasileiras. In J. Ramsey, \& A. Almeida, (Orgs.). A ascensão das multinacionais brasileiras: o grande salto de peso-pesados regionais a verdadeiras multinacionais. Rio De Janeiro: Elsevier.

Fleury, A., \& Fleury, M. T. L. (2011). Brazilian multinationals: competences for internationalization. Cambridge University Press.

Foss, N. J. (1993). Theories of the firm: Contractual and competence perspectives. Journal of evolutionary economics, 3(2), 127-144.

Foss, N. J. (1997). The resource-based perspective: an assessment and diagnosis of problems. Scandinavian Journal of management, 14(3), 133-149.

Foss, N. J. (2003). Selective intervention and internal hybrids: Interpreting and learning from the rise and decline of the Oticon spaghetti organization. Organization Science, 14(3), 331349. 
Foss, N. J. (2007). The emerging knowledge governance approach: Challenges and characteristics. Organization, 14(1), 29-52.

Foss, N. J., \& Mahoney, J. T. (2010). Exploring knowledge governance. International Journal of Strategic Change Management, 2(2-3), 93-101.

Foss, N. J., \& Stieglitz, N. (2010). Modern resource-based theory. In S. L. Newbert, (2007). Empirical research on the resource-based view of the firm: an assessment and suggestions for future research. Strategic management journal, 28(2), 121-146

Fratianni, M., \& Oh, C. H. (2009). Expanding RTAs, trade flows, and the multinational enterprise. Journal Of International Business Studies, 40(7): 1206-1227.

Furman, J. L., Porter, M. E., \& Stern, S. (2002). The determinants of national innovative capacity. Research Policy, 31(6), 899-933.

Garrido, C. (1999). El Caso Brasileño. In D. Chudnovsky, B. Kosacoff \& A. López (Orgs.). Las multinacionales latino americanas: sus estrategias en un mundo globalizado. Buenos Aires: Fondo De Cultura Económica De Argentina S.A.

Ghemawat, P. (2001). The Cross-Border Integration of Markets and International Business. HBS Comp. \& Strategy Unit Working Paper No. CS5701.

Ghemawat, P. (2003). Globalization: the strategy of differences. Harvard Business Review.

Gil, A. C. (2011). Métodos e técnicas de pesquisa social. São Paulo: Editora Atlas.

Gil, S., Llorca, R., \& Serrano, J. A. M. (2008). Measuring the impact of regional export promotion: The Spanish case. Papers in Regional Science, 87(1), 139-146.

Glaister, K. W., \& Buckley, P. J. (1996). Strategic motives for international alliance formation. Journal of Management studies, 33(3), 301-332.

Glendon, M. A., Gordon, M. W., \& Osakwe, C. (1994). Comparative Legal Tradition: Text, Materials, and Cases on the Civil and Common Law Traditions, with Special Reference to French, German, English, and European Law. West.

Gomez-Mejia, L. R., \& Palich, L. E. (1997). Cultural diversity and the performance of multinational firms. Journal Of International Business Studies, 28(2), 309-335.

Gordon, R. H., \& Bovenberg, A. L. (1996). Why is capital so immobile internationally? Possible explanations and implications for capital income taxation. The American Economic Review, 1057-1075.

Grandori, A. (2001). Neither hierarchy nor identity: knowledge-governance mechanisms and the theory of the firm. Journal of management and Governance, 5(3-4), 381-399. 
Granstrand, O. (1998). Towards a theory of the technology-based firm. Research policy, 27(5), 465-489.

Grant, R. M. (1996). Toward a knowledge-based theory of the firm. Strategic management journal, 17(S2), 109-122.

Griffith, D. A., \& Harvey, M. G. (2001). A resource perspective of global dynamic capabilities. Journal of International Business Studies, 32(3), 597-606.

Grosse, R. (2005). International business and government relations in the 21 st century. Cambridge University Press.

Guedes, A. L. (2006). Internacionalização de empresas como política de desenvolvimento: uma abordagem de diplomacia triangular. RAP, Rio de Janeiro, 40(3), 335-56.

Guille'N, M., \& Suarez, S. (2001). The institutional context of multinational activity. In S. Ghoshal \& E. Westney (Orgs.). Organization theory and the multinational corporation, 123145. New York: Palgrave Macmillan.

Gujarati, D. N. (2006). Econometria Básica. Campus, Rj : Elsevier.

Håkanson, L., \& Ambos, B. (2010). The antecedents of psychic distance. Journal of International Management, 16(3), 195-210.

Hamel, G., \& Prahalad, C. K. (1995). Competindo pelo futuro. Rio de janeiro: Campus, 301.

Hamilton, C., \& Winters, L. (1992). Opening up international trade with Eastern Europe. Economic Policy, 7(14): 7-116.

Harding, T., \& Javorcik, B. (2007). Developing economies and international investors: Do investment promotion agencies bring them together?. World Bank Policy Research Working Paper, (4339).

Harding, T., \& Javorcik, B. (2010). Roll out the red carpet and they will come: investment promotion and FDI inflows, The Global Economy, 121(557), 1445-1476.

Harding, T., \& Javorcik, B. S. (2011). Roll out the red carpet and they will come: Investment promotion and FDI inflows. The Economic Journal, 121(557), 1445-1476.

Harris, R. I., \& Cherli, Q. (2005). Review of the literature: the role of international trade and investment in business growth and development. Report to UKTI.

Harzing, A. W. (2004). The role of culture in entry-mode studies: from neglect to myopia? Advances In International Management 15(15), 75-127. 
Haussmann, H., Holtbrügge, D., Rygl, D., \& Schillo, K. (2006). Erfolgsfaktoren mittelständischer weltmarktführer. University Of Erlangen-Nuremberg, Working Paper 3/2006.

Hayakawa, K., Lee, H. H., \& Park, D. (2010). Investment promotion agencies: do they work?.

Hayakawa, K., Lee, H. H., \& Park, D. (2011). Do export promotion agencies increase exports?.

Hayakawa, K., Lee, H., \& Park, D. (2014). Are investment promotion agencies effective in promoting outward foreign direct investment? the cases of Japan And Korea. Asian Economic Journal, 28(2), 111-138.

Hayakawa, K. T., Matsuura, T., Motohashi, K., \& Obashi, A. (2013). A two-dimensional analysis of the impact of outward FDI on performance at home: Evidence from japanese manufacturing firm. Japan and the World Economy, 27: 25-33.

Hayek, F. A. (1945). The use of knowledge in society. The American economic review, 35(4), 519-530.

Heiman, B., \& Nickerson, J. A. (2002). Towards reconciling transaction cost economics and the knowledge-based view of the firm: The context of interfirm collaborations. International Journal of the Economics of Business, 9(1), 97-116.

Hemais, C. A. (2005). O Desafio dos mercados externos: Teoria e prática na internacionalização da firma (2nd ed.). Rio de Janeiro: Mauad.

Hendriks, P. H. J., \& Vriens, D. J. (1999). Knowledge-based systems and knowledge management: friends or foes? Information \& Management 35(2), 113-125.

Henisz, W. J. (2000). The institutional environment for multinational investment. Journal of Law, Economics, and Organization, 16(2), 334-364

Henisz, W. J., \& Williamson, O. E. (1999). Comparative economic organization-within and between countries. Business and Politics, 1(3), 261-277.

Hennart, J. F. (2009). Down with MNE-centric theories! Market entry and expansion as the bundling of mne and local assets. Journal of International Business Studies, 40, 1432-1452.

Hennart, J., \& Larimo, J. (1998). The impact of culture on the strategy of multinational enterprises: does national origin affect ownership decisions?. Journal of International Business Studies, 29(3): 515-538.

Hermais, C. A., \& Hilal, A. (2004). Teorias, paradigmas e tendências em negócios internacionais: de Hymer ao empreendedorismo. In C. A. Hermais, (Org.). O desafio de mercados externos: teoria e prática na internacionalização da firma. Rio de Janeiro: Mauad, 1, 17-39. 
Hibbert, E. P. (1989). The management of international trade promotion. London: Routledge.

Hoekman, B, \& Javorcik, B. S. (2006). Lessons from empirical research on international technology diffusion through trade and foreign direct investment. In B. Hoekman, B. S. Javorcik (Orgs.). Global integration and technology transfer, 225, 1.

Hofstede, G. (1980). Culture's consequences: International differences in work-related values. Beverly Hills, CA: Sage Publications.

Hofstede, G. (1997). Cultures and organizations: software of the mind. New York: Mcgraw Hill

Hofstede, G. (2006). What did globe really measure? Researchers' minds versus respondents' minds. Journal of International Business Studies, 37(6), 882-896. Doi: 10.1057/Palgrave.Jibs. 8400233

Holtz-Eakin, D., Newey, W., \& Rosen, H. S. (1988). Estimating vector autoregressions with panel data. Econometrica: Journal of the Econometric Society, 1371-1395.

Hörnell, E., Vahlne, J. E., \& Wiedersheim-Paul, F. (1973). Export och utlandsetableringar. Almqvist \& Wiksell.

House, R. J., Hanges, P. J., Javidan, M., Dorfman, P. W., \& Gupta, V. (2004). Culture, leadership, and organizations: The GLOBE study of 62 societies. Sage publications.

Hymer, S. (1960). The international operations of national firms: a study of direct foreign investment. Cambridge, Ma: Mit Press.

Hymer, S. (1976): The international operations of national firms: a study of direct foreign investment. Cambridge: Mit Press.

Hymer, S. (1983). Empresas multinacionais: a internacionalização do capital.Rio de Janeiro: Graal.

IFC (1998): Casamento De Conveniência. Hsm Management. International Finance Corporation. São Paulo, Edição Fev/98, 12-16.

Iglesias, R. M.; Veiga, P. M. (2002): Promoção de exportações via internacionalização das firmas de capital brasileiro. In A. C. Pinheiro, R. Markwald, L. V. Pereira, (Orgs.). (2002). $O$ Desafio Das Exportações. Rio De Janeiro: BNDES (1a ed), 367- 446.

Iglesias, R. M., \& Veiga, P. M. (2005). Investimento das firmas brasileiras no exterior: Algumas hipóteses e resultados de uma pesquisa entre exportadores. In C. C. Hemais, (Org.). O desafio dos mercados externos: Teoria e prática na internacionalização da firma (2a ed). Rio De Janeiro: Mauad. 
Inglehart, R., \& Baker, W. E. (2000). Modernization, cultural change, and the persistence of traditional values. American Sociological Review, 65(1), 19-51. Doi: 10.2307/2657288

IPEA. (2012). Internacionalização de empresas: Experiências internacionais selecionadas, 131.

Jackson, G., \& Deeg, R. (2008). Comparing capitalisms: Understanding institutional diversity and its implications for international business. Journal of International Business Studies, 39(4), 540-561.

Janeba, E. (2002). Attracting FDI in a politically risky world. International Economic Review, 43(4), 1127-1155.

Jaramillo, C. (1992). The basic functions of national trade promotion organizations. In International Trade Forum (No. 3, p. 18). International Trade Centre.

Jeannet, J.-P.; Hennessey, H. D. (1992): Global marketing strategies (2 ${ }^{\text {nd }}$ ed.). Boston: Houghton Mifflin Company.

Johanson, J., Mattsson, L.G. (1988): Internationalization in industrial system: A Network Approach. In N. Hood, J. E. Vahlne, (Orgs.). Strategies for Global Competition. London: Croom Helm.

Johanson, J., \& Vahlne, J. E. (1977). The internationalization process of the firm-a model of knowledge development and increasing foreign market commitments. Journal of international business studies, 8(1), 23-32.

Johanson, J., \& Vahlne, J. E. (1990). The mechanism of internationalisation. International marketing review, 7(4).

Johanson, J.; Vahlne, J. E. (2003): Business relationship learning and commitment in the internationalization process. Journal of International Entrepreneurship, 1(1), 83-101.

Johanson, J., \& Wiedersheim-Paul, F. (1975). The internationalization of the firm-four swedish cases 1. Journal of management studies, 12(3), 305-323.

Joliet, R., \& Hubner, G. (2003). Firm internationalization and systematic risk: a multinational approach. Manuscrito inédito. Recuperado de http://www. researchgate. net/publication/228876279 _ Firm _ Internationalization _ and _ Systematic _ Risk _ $a_{-}$ multidimensional_approach.

Kester, W. C. (1996). American and Japanese corporate govern- ance. In S. Berger, \& R. Dore, (Orgs.). National diversity and global capitalism (pp. 107-137). Cornell University Press. 
Klein, B., Crawford, R.G., \& Alchian, A. A. (1978). Appropriable rents and the competitive contracting process. The Journal of Law and Economics, 21(2), 297-326.

Kleinert, J., \& Toubal, F. (2010). Gravity for FDI. Review of International Economics, 18(1), $1-13$.

Kogut, B. (2002). International management and strategy. Handbook of strategy and management, 261-278.

Kogut, B., \& Singh, H. (1988). The effect of national culture on the choice of entry mode. Journal of International Business Studies, 19(3), 411-432. Doi: 10.2307/155133

Kosacoff, B. (1999). Hacia un mayor entorno competitivo de la producción automotriz en Argentina, Working Paper, (82).

Kostova, T. (1997). Country institutional profiles: concept and measurement. Academy Of Management Proceedings, 1997(1), 180-184. Doi: 10.5465/Ambpp.1997.4981338

Kostova, T. (1999). Transnational transfer of strategic organizational practices: a contextual perspective. Academy Of Management Review, 24(2), 308-324. Doi: 10.5465/Amr.1999.1893938

Kotler, P. (1998). Administração de marketing: análise, planejamento, implementação e controle. São Paulo: Atlas.

Kotler, P. (2000). Administração de marketing: a edição do novo milênio. (10 a ed). São Paulo: Prentice Hall.

Kray, A. (2006). Exports and economic performance. In B. Hoekman, \& B. S. Javorcik. Global integration and technology transfer.

Kretzer, J., \& Menezes, E. A. (2006). A importância da visão baseada em recursos na explicação da vantagem competitiva. Revista De Economia Mackenzie. 4(4), 63-87.

Krugman, P. (1996). Internacionalismo pop. Rio de Janeiro: Campus.

Krugman, P. R., \& Obstefeld, M. (2001). Economia internacional: teoria e política. (5 ed). São Paulo: Makron Books.

Kutschker, M., \& Schmid, M. (2005). Internationales Management (4 ed.). München,Wien: Oldenbourg.

La Porta, R., Lopez-De-Silanes, F., Shleifer, A., \& Vishny, R. W. (1998). Law and finance. Journal Of Political Economy, 106(6), 1113-1155. 
Lederman, D., Olarrega, M., \& Payton, L. (2006). Export promotion agencies: what works and what doesn't. World Bank Policy Research Working Paper, (4044).

Lederman, D., Olarreaga, M., \& Payton, L. (2010). Export promotion agencies: Do they work?. Journal of development economics, 91(2), 257-265.

Lee, K.C., Lee, S., \& Kang, I.W.(2005). Kmpi: measuring knowledge management performance. Information\& Management, 42(3), 469-482.

Lemos, F. L. (2013). A political view on the internationalization process. (Doctoral dissertation, Uppsala University).

Levinthal, D. A. (1998). The slow pace of rapid technological change: gradualism and punctuation in technological change. Indust. Corporate Change, 7(2), 217-247.

Lewis, R. J. (1990). Foreword. In S. T. Cavusgil, \& M. R. Czinkota, (Orgs.). International perspectives on trade promotion and assistance. New York: Quorum Books.

Lima, M. R. S. (2005). Aspiração Internacional e Política Externa. Revista Brasileira de Comércio Exterior, 82, 1-21.

Lindenberg, S. (2003). The cognitive side of governance. Research in the Sociology of Organizations, 20, 47-76.

Linder, S. (1961). An essay on trade an transformation. New York: John Wiley.

Linnemann, H. (1966). An international study of international trade flows. Amsterdam: North-Holland.

Lipsey, R. E., \& Weiss, M. Y. (1984). Foreign production and exports of individual firms. The Review of Economics and Statistics, 304-308.

Macharzina, K., \& Engelhard, J. (1991). Paradigm shift in international business research: From partist and eclectic approaches to the GAINS paradigm. MIR: Management International Review, 23-43.

Magnusson, P., Wilson, R. T., Zdravkovic, S., Xin Zhou, J., \& Westjohn, S. A. (2008). Breaking through the cultural clutter: a comparative assessment of multiple cultural and institutional frameworks. International Marketing Review, 25(2), 183-201. Doi: 10.1108/02651330810866272.

Malerba, F., \& Orsenigo, L. (2000). Knowledge, innovative activities and industrial evolution. Industrial and corporate change, 9(2), 289-314.

Malhotra, N.K. (2001). Pesquisa de marketing: uma orientação aplicada. São Paulo: Bookman Companhia.

March, J.G., \& Simon, H.A. (1993). Organizations (2 ed.). Blackwell: Cambridge. 
Marinho, P. L. (2013). Explicações sobre a internacionalização produtiva das empresas: das teorias clássicas às novas teorias explicações (Tese de Doutorado, Universidade Federal Do Paraná).

Martincus, C. V., \& Carballo, J. (2008). Is export promotion effective in developing countries? Firm-level evidence on the intensive and the extensive margins of exports. Journal of International Economics, 76(1), 89-106.

Matthews, J. A. (2006a). Dragon multinationals: New players in 21st century globalization. Asia Pacific journal of management, 23(1), 5-27.

Matthews, J. A. (2006b). Response to professors Dunning and Narula. Asia Pacific Journal of Management, 23(2), 153-155.

Meyer, J. W., \& Rowan, B. (1977). Institutionalized organizations: formal structure as myth and ceremony. American Journal Of Sociology, 83(2), 340-363. Doi: 10.2307/2778293.

Mill, J. S. (1983). Princípios de economia política: com algumas de suas aplicações à filosofia social. São Paulo: Abril Cultural.

Milman, C. D. (1996). Determinants of private direct investment in Latin America: strategic implications. International Journal of Management, 13, 380-389.

Minbaeva, D., Pedersen, T., Björkman, I., Fey, C.F., \& Park, H.J. (2003). MNC knowledge transfer, subsidiary absorptive capacity, and HRM. Journal of International Business Studies, 34 (6), 586-599.

Minervini, N. (1991). O Exportador. São Paulo: Mcgraw-Hill.

Miskinis, A., Byrka, M. (2014). The role of investment promotion agencies at attracting foreign direct investment. Ekonomika, 93(4), 41-57.

Moran, T. H., Graham, E. M., \& Blomström, M. (2005). Does foreign direct investment promote development? Washington, D.C.: Institute for International Economics and Center for Global Development.

Morck, R., \& Yeung, B. (1991). Why investors value multi- nationality. Journal Of Business, 64(2), 65-187.

Morisset, J., Mirioux, A., \& Smith, N. (2003). Does a country need a promotion agency to attract foreign direct investment? A small analytical model applied to 58 countries. World Bank Policy Research Working Paper.

Morisset, J., \& Andrews-Johnson, K. (2004). The effectiveness of promotion agencies at attracting foreign direct investment (Vol. 16). World Bank Publications.

Morosini, P., Shane, S., \& Singh, H. (1998). National cultural distance and cross-border acquisition performance. Journal of international business studies, 29(1), 137-158. 
Mudambi, R., \& Navarra, P. (2002). Institutions and internation business: a theoretical overview. International Business Review, 11(6), 635-646.

Mumlidharan, R., \& Phatak, A. (1999). International R\&D activity of US MNCs: an empirical study with implications for host government policy. Multinational Business Review, 7 (2), 97-105.

Musacchio, A., \& Lazzarini, S. G. (2013). Leviathan in business: varieties of state capitalism and their implications for economic performance. SSRN Electronic Journal SSRN Journal. Doi: $10.2139 /$ ssrn.2070942

Nachmias, C., \& Nachmias, D. (1996). Research methods in the social sciences. New York: St. Martin 'S Press.

Navaretti, G. B., Castellani, D., \& Disdier, A. C. (2010). How does investing in cheap labour countries affect performance at home? Firm-level evidence from France and Italy. Oxford Economic Papers, 62(2), 234-260.

Nelson R., Winter S. (1982). An evolutionary theory of economic change. Belknap Press of Harvard University Press: Cambridge.

Nelson, R. R., \& Rosenberg, N. (1993). Technical innovation and national systems. National innovation systems: A comparative analysis, 322.

Neto, D. T. (2007). Como as empresas brasileiras estão enfrentando os desafios da internacionalização. Internacionalização de empresas brasileiras: perspectivas e riscos. Rio de Janeiro: Elsevier.

Neumann, M. (1995). Theoretische volkswirtschaftslehre ii: produktion. Nachfrage und Allokation, München.

Lee, N. S., \& Soutar, G. (2007). Are Hofstede's and Schwartz's value frameworks congruent? International Marketing Review, 24(2), 164-180.

Nickels, W. G., Wood, M. B.(1997). Marketing: relationships, quality, value. New York: Worth Publishers.

Nickerson, J., \& Zenger, T. (2004). A knowledge-based theory of the firm: The problemsolving perspective. Organization Science, 15(6), 617-632

Nonaka, I., \& Takeuchi, H. (1997). Criação do conhecimento na empresa, Rio De Janeiro: Elsevier.

Nordström, K., \& Vahlne, J. (1992). Is the globe shrinking: Psychic distance and the establishment of Swedish sales subsidiaries during the last 100 years. International Trade And Finance Association's Annual Conference, Texas: Proceeding, 242-259. 
North, D. C. (1990). Institutions, institutional change and economic performance. Cambridge university press.

North, D.C. (1991). Institutions. Journal of Economic Perspectives, 5(1), 97-112.

O'Grady, S., \& Lane, H.W. (1996). The psychic distance paradox. Journal of International Business Studies, 27 (2), 309-333.

Oviatt, B. M., \& McDougall, P. P. (1994). Toward a theory of international new ventures. Journal of international business studies, 25(1), 45-64.

Pajunen, K. (2008). Institutions and inflows of foreign direct investment: A fuzzy-set analysis. Journal of International Business Studies, 39(4), 652-669.

Park, S. H., \& Ungson, G. R. (1997). The effect of national culture, organizational complementarity, and economic motivation on joint venture dissolution. Academy Of Management Journal, 40(2), 279-307. Doi: 10.2307/256884.

Parsons, T. (1951). The Social System. New York: The Free Press.

Pavitt, K. (1990). Some foundations for a theory of the large innovating firm. Falmer: S.P.R.U,

Pavitt, K. (1998). Technologies, products and organization in the innovating firm: what Adam Smith tells us and Joseph Schumpeter doesn't. Industrial and Corporate change, 7(3), 433452.

Pearce, R. D. (1990). Overseas production and exporting performance: Some further investigations. University of Reading.

Penrose, E. T. (1956). Foreign investment and the growth of the firm. The Economic Journal, 66(262), 220-235.

Penrose, E. T. (1959). The theory of the growth of the firm. Oxford: Oxford University Press.

Penrose, E. T. (1960). The growth of the firm - a case study: the Hercules Powder Company. Business History Review, 34(01), 1-23.

Penrose, E. T. (1995). The theory of the growth of the firm, 1959. Cambridge, MA.

Penrose, E. T. (2006). A teoria do crescimento da firma. Editora Unicamp.

Penrose, E.T. (2007). Facteurs, Conditions Et Mécanismes De La Croissance De L'Entreprise. In A. B. Cyrino, Editions Hommes Et Techniques.

Perlitz, M. (2000): Internationales Management. Stuttgart: Auf. 
Petersen, B., Pedersen, T., \& Sharma, D. D. (2003). The role of knowledge in firms internationalisation process: Wherefrom and whereto. Learning in the internationalisation process of firms, 36-55.

Pinheiro, A. C., Markwald, R., \& Pereira, L. V. (2002). O desafio das exportações (1a ed.). Rio de Janeiro: BNDES.

Polanyi, M. (1983). The Tacit Dimension. Gloucester, Peter Smith.

Porter, M. (1986). Estratégia competitiva: técnicas para análise de indústrias e da concorrência. (7a Ed.). Rio De Janeiro: Campus.

Porter, M. E. (1989). A vantagem competitiva das nações. Rio de Janeiro: Campus.

Porter, M. E. (1990). Vantagem Competitiva. Rio De Janeiro: Campus.

Porter, M. E. (1999). Competição: on competition: estratégias competitivas essenciais. Rio de Janeiro: Campus.

Prahalad, C K., \& Hamel, G. (1990). The core competence of the corporation. Harvard Business Review, 68(3), 79-91.

Probst, G., Raub S.m \& Romhardt, K. (2002). Gestão do conhecimento: os elementos construtivos do sucesso. Porto Alegre: Bookmark.

Ramamurti, R., \& Singh, J. V. (2009). Emerging multinationals in emerging markets. Cambridge University Press.

Rao, A., \& Schmidt, S. M. (1998). A behavioral perspective on negotiating international alliance. Journal of International Business Studies, 29(4), 665-694.

Rennie, M. W. (1993). Global Competitiveness: Born Global. The Mckinsey Quarterly, (4), 45- 52.

Ricardo, D. (1982). Princípios de economia politica e tributação. São Paulo: Abril Cultural.

Ricupero, R., \& Barreto, F. M. (2007). A importância do investimento direto estrangeiro do Brasil no exterior para o desenvolvimento socioeconômico do país. Internacionalização de Empresas Brasileiras. Rio de Janeiro: Elsevier.

Rios, S.P. (2002). O papel das negociações comerciais na agenda econômica do futuro governo. Revista Brasileira De Comércio Exterior, (72), 42 - 44.

Rios, S.P. (2006). O papel dos acordos comerciais na política comercial brasileira. Revista Brasileira De Comércio Exterior, (87), 34 - 39.

Rocha, A. (1988). Gerência de exportação no Brasil. São Paulo: Atlas. 
Ronen, S., \& Shenkar, O. (2013). Mapping world cultures: cluster formation, sources and implications. Journal of International Business Studies, 44(9), 867-897.

Roodman, D. (2009). A note on the theme of too many instruments. Oxford Bulletin of Economics and statistics, 71(1), 135-158.

Roos, J. (1989). Cooperative Venture Formation Processes: Characteristics And Impact On Performance. (Dissertação de Doutorado). Stockholm School Of Economics.

Rosenbloom, R.S., \& Christensen, C.M. (1994). Technological discontinuities, organizational Capabilities, and strategic commitments. Industrial and Corporate Change, 3(3), 655-85.

Rosenzweig, P.M., \& Nohira, N. (1994). Influences on human resource management practices in multinational corporations. Journal of International Business Studies, 25 (3), 229-251.

Rugman, A. M. (1981). Inside the multinationals: The economics of internal markets. New York: Columbia University Press.

Salerno, M. S. \& De Negri, J. A. (2005). Inovação, Estratégias Competitivas E Inserção Internacional Das Firmas Da Indústria Brasileira. Parcerias Estratégicas, (20), 1309-1333.

Sampieri, R., Collado, C., \& Lucio, P. (1991). Metodologia De La Investigación. McgrawHill.

Sarti, F., \& Laplane, M.F. (2002). O Investimento Direto Estrangeiro E A Internacionalização Da Economia Brasileira Nos Anos 1990. Economia E Sociedade, 11(18), 63-94.

Sauvant, K. P. (2005). New sources of FDI: the BRICs-outward FDI from Brazil, Russia, India and China. J. World Investment \& Trade, 6(5), 639-710.

Sauvant, K. P. (2007). O Investimento Direto Estrangeiro Dos Bric (Brasil, Rússia, Índia E China) No Exterior. In A. Almeida, (Org.). Internacionalização De Empresas Brasileiras: Perspectivas E Riscos. Fundação Dom Cabral, Rio De Janeiro: Elsevier, 37 - 77.

Sauvant, K. P., \& Reimer, J. (2012). FDI Perspectives: Issues in International Investment. (2nd. Ed). Vale Columbia center on sustainable international investment.

Sauvant, K. P., Economou, P., Gal, K., Lim, S., \& Wilinski, W. P. (2014). Trends in FDI, home country measures and competitive neutrality. Yearbook on International Investment Law \& Policy 2012-2013, 3-107.

Schiffman, L.G., \& Kanuk, L.L. (2000). Consumer Behavior. New Jersey: Prentice-Hall.

Schneider, F., \& Frey, B. S. (1985). Economic and political determinants of foreign direct investment. World development, 13(2), 161-175. 
Schneider, S. C., \& De Meyer, A. (1991). Interpreting and responding to strategic issues: The impact of national culture. Strategic management journal, 12(4), 307-320.

Scott, W. R. (1995). Institutions and Organizations. Thousand Oaks, Ca: Sage

Selltiz, C. (1987). Métodos De Pesquisa Nas Relações Sociais. São Paulo: E.P.U. Pedagógica E Universitária.

Sennes, R., \& Mendes, R. (2009). Políticas públicas e as multinacionais brasileiras. RAMSEY, $J$. A ascensão das multinacionais brasileiras: o grande salto de pesos-pesados regionais a verdadeiras multinacionais. Rio de Janeiro: Elsevier.

Seringhaus, F. R., \& Botschen, G. (1991). Cross-national comparison of export promotion services: the views of Canadian and Austrian companies. Journal of International Business Studies, 22(1), 115-133.

Serven, L., \& Solimano, A. (1993). Debt crisis, adjustment policies and capital formation in developing countries: where do we stand?. World Development, 21(1), 127-140.

Shane, S. A. (1992). The effect of cultural differences in perceptions of transaction costs on national differences in the preference for licensing. Management International Review, 32, 295-311.

Shenkar, O. (2001). Cultural distance revisited: Towards a more rigorous conceptualization and measurement of cultural differences. Journal of international business studies, 32(3), 519-535.

Silva Júnior, L.A., \& Rodrigues, L. C. A. (2002). Internacionalização Ou Globalização De Empresas? Uma Discussão Reflexiva Sobre Estratégias De Marketing. Fortaleza, Revista Do Centro De Ciências Administrativas, 8 (2), 142-153.

Simon, H. (1947). Administrative behavior: a study of decision-making processes in administrative organizations (4th ed). The Free Press, New York

Simon, H. (1972). Theories of bounded rationality. Decision and organization, 1(1), 161-176.

Simon, H. (1983). Reason in human affairs. Stanford: Stanford University Press.

Simonin, B. L. (1999). Transfer of marketing know-how in international strategic alliances: An empirical investigation of the role and antecedents of knowledge ambiguity. Journal of International business studies, 30(3), 463-490.

Slangen, A. H. (2006). National cultural distance and initial foreign acquisition performance: The moderating effect of integration. Journal of World Business, 41(2), 161-170.

Slangen, A. H., \& Hennart, J. F. (2008). Do multinationals really prefer to enter culturally distant countries through greenfields rather than through acquisitions? The role of parent 
experience and subsidiary autonomy. Journal of International Business Studies, 39(3), 472490.

Smith, A. (1985). A Riqueza das Nações: investigação sobre sua natureza e suas causas. (2a ed.). São Paulo: Nova Cultural.

Smith, M., Dowling, P. J., \& Rose, E. L. (2011). Psychic distance revisited: A proposed conceptual framework and research agenda. Journal of Management \& Organization, 17(01), 123-143.

Smith, R.E. (1996). Globalização, regionalização e emprego: implicações para a américa latina. In H. Zylberstajn, (Org.). (1996): Processos De Integração Regional E A Sociedade: O Sindicalismo Na Argentina, Brasil, México E Venezuela. Rio De Janeiro: Paz E Terra.

Sousa, C. M., \& Bradley, F. (2006). Cultural distance and psychic distance: two peas in a pod?. Journal of International Marketing, 14(1), 49-70.

Sousa, F., \& Lemos, F. (2009). Complexity and independency in firms internationalization: when the state become the partner. International Journal of Business Environment, 4(2), 485504.

Stehn, J. (1992). Ausländische Direktinvestitionen in Industrieländern: theoretische Erklärungsansätze und empirische Evidenz (No. 470). Kiel Institute for the World Economy (IfW).

Stinchcombe, A. L. (1965). Social structures and organization. In J. G. March, (Org.). (1965). Handbook of organizations. Chicago: Rand Mcnally, P.142-193.

Stoner, J. A. F., \& Freeman, R. E. (1995). Administração. Rio de Janeiro: Prentice Hall.

Stopford, J. M., Strange, S., \& Henley, J. S. (1991). Rival states, rival firms: Competition for world market shares (Vol. 18). Cambridge University Press.

Strange, S. (1994). States And Markets (2a ed). London: Pinter.

Strange, S. (1996). The retreat of the state: The diffusion of power in the world economy. Cambridge university press.

Strange, S. (2000). States, firms, and diplomacy. International political economy: Perspectives on global power and wealth, 60-67.

Stulz, R. M. (1981). On the effects of barriers to international investment. The Journal of Finance, 36(4), 923-934.

Swedenborg, B. (1979). The multinational operations of Swedish firms: An analysis of determinants and effects. Stockholm: Industrial Institute for Economic and Social Research.

Swedenborg, B. (1985). Sweden. In J.H. Dunning, (Org.). Multinational enterprises, economic structure and international competitiveness. Chichester 
Teece, D. J. (1985). Multinational enterprise, internal governance, and industrial organization. The American Economic Review, 75(2), 233-238.

Teece, D. J. (1986a). Profiting from technological innovation: Implications for integration, collaboration, licensing and public policy. Research policy, 15(6), 285-305.

Teece, D. J. (1986b). Transactions cost economics and the multinational enterprise An Assessment. Journal of Economic Behavior \& Organization, 7(1), 21-45.

Teece. D. J. (1998). Capturing value from knowledge assets. California Management Review, 40(3), 55- 79.

Teece, D., \& Pisano, G. (1994). The dynamic capabilities of firms: an introduction. Industrial and corporate change, 3(3), 537-556.

Terpstra, K., \& Sarathy, R. (1997). International Marketing. Orlando: The Dryden Press.

Tinbergen, J. (1963). Shaping the world economy. The International Executive, 5(1), 27-30.

Trompenaars, F., \& Hampden-Turner, C. (1998). Riding the waves of culture: understanding cultural diversity in business. New York: Mcgraw-Hill Education.

Uhlenbruck, K. (2004). Developing acquired foreign subsidiaries: The experience of MNEs in transition economies. Journal of International Business Studies, 35(2), 109-123.

UNCTAD. (1995). World investment report 1995: policies on outward foreign direct investment. New York: United Nations.

UNCTAD. (1996). World investment report 1996: investment, trade and international policy arrangements. New York And Geneva: United Nations.

UNCTAD. (2004). World investment report: outward fdi from developing countries sis becoming important. New York and Geneva: United Nations.

UNCTAD. (2005). World investment report 2005: transnacional corporations and the internationalization $O f R \& D$. New York and Geneva: United Nations.

UNCTAD. (2006). World investment report 2006: FDI from developing and transition economies: implications for development. UN.

UNCTAD. (2008). Investment promotion agencies as policy advocates. New York and Geneva.

UNCTAD. (2011). World investment report 2011. [S.L.: S.N.], Recuperado em 12 Abril, 2016, de Http://Oebs.Co.At/De/Img/Unctad__World_Investment_Report_2011_Tcm14236053.Pdf. 
UNCTAD. (2012). World investment report: Towards a new generation of investment policies. Unite Nations. New York and Geneva.

USAID. (2004). Best Practices In Export Promotion. Usaid Technical Report.

Vahlne, J. E., \& Nordström, K. A. (1992). Is the globe shrinking: Psychic distance and the establishment of Swedish sales subsidiaries during the last 100 years.

Valor. (2011). “Anuário Das Multinacionais Brasileiras”. Complemento do Jornal Valor Economico, 4(4).

Vernon, R. (1966). International investment and international trade in the product cycle. Quarterly journal of economics, 80 (2), 190-207.

Vernon, R. (1972). Manager in the international economics. (2a ed). New Jersey: PrenticeHall, Inc.

Vernon, R. (1979). The product cycle hypothesis in a new international environment. Oxford bulletin of economics and statistics, 41(4), 255-267.

Vietor, R. H. (2007). How countries compete: Strategy, structure, and government in the global economy. Harvard Business Press.

Wai, T., \& Wong, C. H. (1982). Determinants of private investment in latin america. Economic Development and Culture Change, 28 (2).

Walldorf, E. G. (1987). Auslandsmarketing: theorie und praxis des auslandsgeschäfts. Springer-Verlag.

Wang, C., Hong, J., Kafouros, M., \& Wright, M. (2012). Exploring the role of government involvement in outward FDI from emerging economies. Journal of International Business Studies, 43(7), 655-676.

Webber, R. A. (1969). Convergence or divergence. Columbia Journal of World Business, $4(3), 75-83$.

Weber, Y., Shenkar, O., \& Raveh, A. (1996). National and corporate cultural fit in mergers/acquisitions: an exploratory study. Management Science, 42(8), 1215-1227. Doi: 10.1287/Mnsc.42.8.1215

Weisfelder, C. J. (2001). Internationalization and the multinational enterprise: development of a research tradition. In $\mathrm{C}$. Axinn, \& P. Matthyssens, (Orgs.). Reassessing The Internationalization Of The Firm. Amsterdam: Jai.

Welch, L. S., \& Luostarinen, R. (1988). Internationalization: evolution of a concept. The Internationalization of the firm, 14, 83-98. 
Welge, M.K., \& Holtbrügge, D. (2003). Internationales management. Stuttgart: SchäfferPoeschel Verlag.

Wells Jr, L. T. (1998). Multinationals and the developing countries. Journal of International Business Studies, 29(1), 101-114.

Wells, L., \& Wint, A. G. (2000). "Marketing A Country," Foreign Investment Advisory Service, Occasional Paper, 13.

Wells, L., \& Wint, A. G. (2001). Marketing A Country, Revisited. Fias Occasional Paper, Number 13. Foreign Investment Advisory Service, Washington, D.C.

Werner, S. (2002). Recent developments in international management research: A review of 20 top management journals. Journal of Management, 28(3), 277-305.

Wernerfelt, B. (1984). A resource-based view of the firm. Strategic management journal, $5(2), 171-180$.

Whitley, R. (1992). Business systems in East Asia: Firms, markets and societies. London: Sage Publications.

Wild, J. J., Wild, K. L. H., \& Jerry, C. Y. (2006). International Business. New Jersey: Prentice-Hall.

Williamson, J. (1989). A Economia aberta ea economia mundial um texto de economia internacional. Rio de Janeiro: Campus.

Williamson, O. E. (1985). The Economic Institutions of Capitalism Firms Markets Relational Contracting.

Williamson, O. E. (1991). Mercados y jerarquías: su análisis y sus implicaciones antitrust (No. 330.1/W72mE).

Williamson, O. E. (1996). The mechanisms of governance. Oxford University Press.

Winter, S. (1984). Schumpeterian Competition in Alternative Technological Regimes, Journal of Economic Behaviour And Organisation, 5, 287-320.

Winter, S. (1987). Knowledge and competence as strategic assets. In D. J. Teece, (Org.). The Competitive Challenge. Cambridge: Ballinger, 159-184.

Wolf, C., \& Weinschrott, D. (1973). International Transactions and Regionalism: Distinguishing" insiders" from" outsiders". The American Economic Review, 63(2), 52-60.

Wooldridge, J. M. (2008). Introductory Econometrics, South Western College. University week, 2. 
Xu, D., \& Shenkar, O. (2002). Note: Institutional distance and the multinational enterprise. Academy of Management review, 27(4), 608-618.

Yeaple, S. R. (2009). Firm heterogeneity and the structure of US multinational activity. Journal of International Economics, 78(2), 206-215.

Yeganeh, H., \& Su, Z. (2006). Conceptual foundations of cultural management research. International Journal of Cross Cultural Management, 6(3), 361-376.

Yeung, H. W. C. (1997). Business networks and transnational corporations: A study of Hong Kong firms in the ASEAN region. Economic Geography, 73(1), 1-25.

Yip, G. S. (2001). Estratégia global em um mundo de nações. MINTZBERG, Henry et al.. O processo da estratégia: conceitos, contextos e casos relacionados, 4, 240-247.

Young, J. P. (1963). The international economy. Ronald Press Co.

Zaheer, S., \& Mosakowski, E. (1997). The dynamics of the liability of foreignness: A global study of survival in financial services. Strategic management journal, 18(6), 439-463.

Zaheer, S., \& Zaheer, A. (1997). Country effects on information seeking in global electronic networks. Journal of International Business Studies, 28(1), 77-100.

Zanatta, M., Camillo, E., Consoni, F., \& Varrichio, P. (2008). Investment Promotion Agencies And The World Competition For Foreign Direct Investment: A Survey Of Institutional Frameworks Direct Investment: A Survey Of Institutional Frameworks. Vii Global Forum On International Investment.

Zucker, L. G. (1991). Postscript: Microfoundations of institutional thought. The new institutionalism in organizational analysis, 103, 106.

Zylbersztajn, D., \& Neves, M. F. (2000). Economia e gestão dos negócios agroalimentares: indústria de alimentos, indústria de insumos, produção agropecuária, distribuição. São Paulo: Pioneira. 